\title{
CARACTERIZAÇÃO DAS FASES SÓLIDA E LIQUIDA DE SOLOS E ARENAS DERIVADOS DO GRANITO SOB FLORESTA TROPICAL AMAZÔNICA (TERRA NOVA DO NORTE - MT)
}

\author{
NILTON TOCICAZU HIGA
}

Orientador: Prof. Dr. CARLOS CLEMENTE CERRI

Tese apresentada à Escola Superior de Agricultura "Luiz de Queiroz", da Universidade de São Paulo, para obtenção do título de Doutor em Agronomia, Área de concentração: Solos $\theta$ Nutrição de Plantas.

\footnotetext{
$P|R A C| C A B A$

Estado de São Paulo - Brasil Julho - 1989
} 


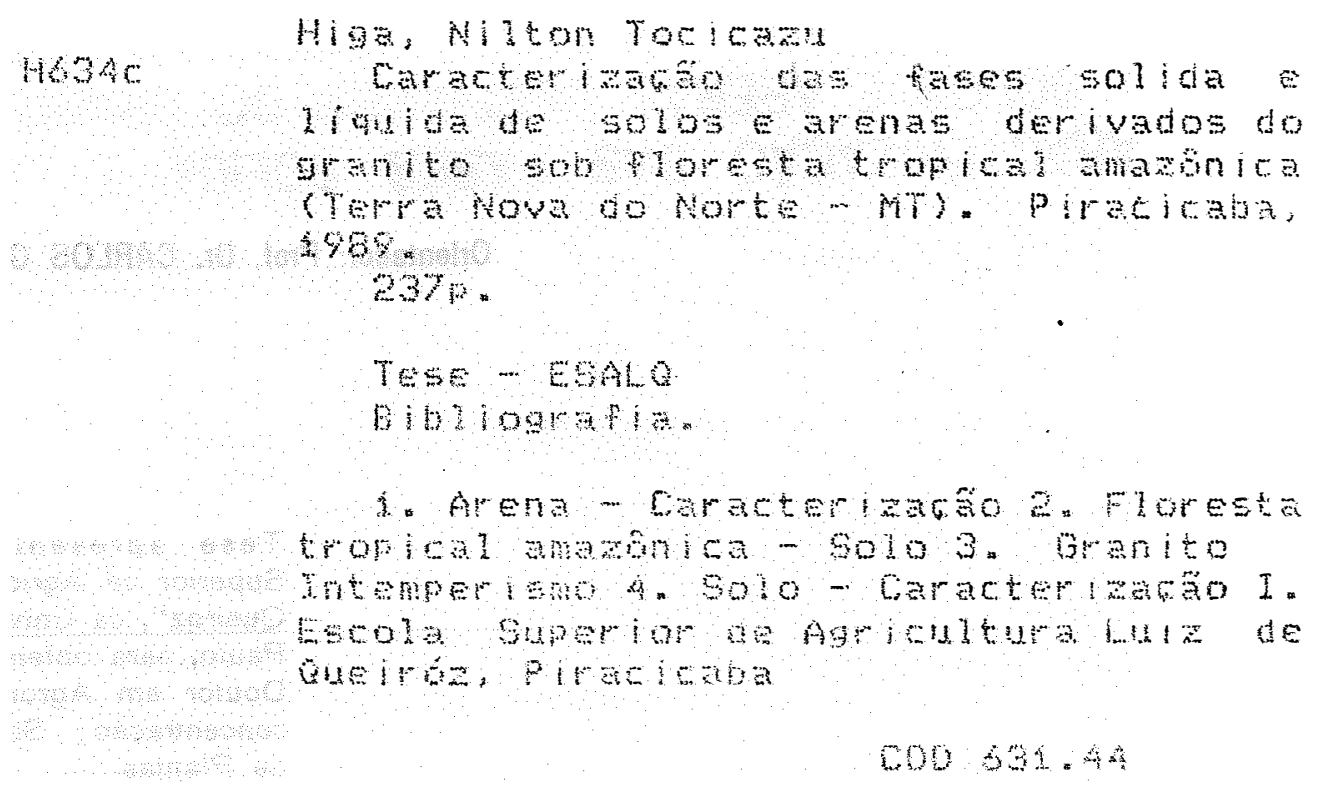


- caracterizaczo das fases sollida e lioutda de solos e ARENAS DERIUADOS DO GRANTTO SOB FLORESTA TRGPICAL AMAZÓNICA ITERRA NOUA DO NORTE - MT?"

NILTON TOCICAZU HIGA

Aprovada em: $19709 / 1989$

Comi şäo. julgadora:

Prof. Dir. KIaUs Reithardt - CENA/USP

Prof. Dr. Zi1mars Ziller Marcos - ESALQ/USP

Prof. Dr. Toshiaki Kinjo-ESALQ/USP

Prof. Dr. Ceiso Augusto Liemente - ESAlo/usp

Prof. Dr. Carlos Clemente Cerri - CENAJUSP

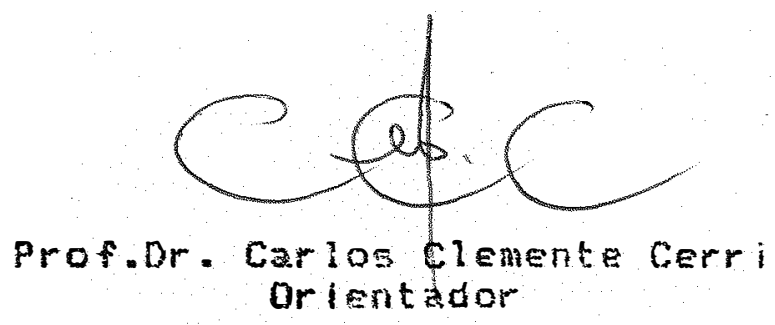


A minta esposa Tereza Cristina e aos meus filhos Fábio e Felipe. dedico. 


\section{AGRADECIMENTOS}

De maneira singela, mas sineera, desejamos registrar nossos agradecinentos e gratidäo as seguintes pesscas e instituifos que nos apoiaram na realizaräo deste trabalto:

- Ao Prof. Dr. CARLos CLEMENTE CERRI pela efetiva orientacáo e apoio na realizacáo deste trabalho e no éranscorrer do curso de Pb́s-Graduagéo;

- AO Dr. BORIS VOLKOFF da DRSTOM \{riranga), que con muita solicitude nos apoiou nos trabalhos de campo;

- AO Dr. FRANCIS ANDREUX da CNRS (Franga) que nos anwiliou com muita presteas nas questoes pertinentes d quimica de solo;

- Ao or. ARMAND ChaUUEL da ORgTOM (Franga) pela especial atengáo a nós concedida nas interprefacos micromorfologicas do solos

- AO Dr. JEAN DELUTGNE da ORSTOM (Franga) Pelo axilio prestado nas interpretakbes mineralogicas das serifes delsadas de rocha e alteritas;

- AO Prof. DF. BERALDO VICTORIND DE FRANGA pela orientacáo na fase inicial do nosso curso de póGraduactó

- Aos técnicos sr. DACTR bortoleto, Sra. SANDRA MARTA BENARO NICOLETTI, Sr. JOSE ROBERTO MARTINS da SEgăo de química do solo, CENAJUSP; Sra. MARIA ELIZABETE H. B.GUTMAREES, ST. ROBERTO FORTI, STA. ELEUSA C.B. BRANCALION do laboratio de solos da ESALQAUSP, pelas valiosas 
contribulobes prestadas nas diversas etapas deste trabalio; E aO Sr. ADEMYR CESAR FRANCO pelo trabatho de digitacáo.

- AO DEPARTAPENTO DE SOLO, GEOLOGTA E FERTILIZANTES da EEALO/USP pela disposizä́o dos laboratorios para a realizacáo das análises fieicas, quimicase mineralódeas das amostra: de solos;

- A SECAOO DE RADIOGUTMTCA E QUTMTCA ANALITICA dO CENANUSP pElo imprescindivel apoio prestado nas andises químicas da solucáo do solo;

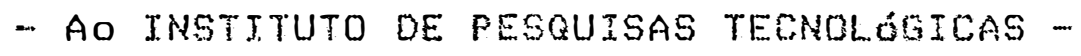
IPT/SP E DEPARTAMENTO DE MINERALDGIA E RECURSOS MINERATS DO TNGTITUTO DE GEDCIENGJAS E CIENCTAS EXATAS DA WNESP, "Campis" de Rio Claro/sp pelo aukilio prestado na confecera das segotes delsadas de rochas, alteritas e solos:

- $\triangle$ TRANGHTD INDUSTRIA DLEDTRAMICA

BRASILEIRA S.A. peía cessáo das placase tubo de aro gue for an utilizados na confect Ǵo do cilindro de compressäbi

- Ao Engenheiro JDRGE AMBRósto FTSHER da TRANSHID pela valiosa colaboracá prestada na elaborafádo do projeto de construso do cilindro de compressa;

- a CONGER S.A. EQUTPANENTOS-PEOCESSOS METAlurgta pela fabricagro do ailindro da compressáo.

- A UNIUERSTDADE FEOERAL DE MATO GROSSO pela concessäo para a realizacáo do boutorado a pelo transporte concedido no transcorrer dos trabalhos de campo.

- A COORDENACAO DE APERFETCOAMENTO OE PESSOAL DE NIVEL SUPERIOR - CAPES" - pela coneEssä́ dí lots de estidos. 
LITA DE FIGURA

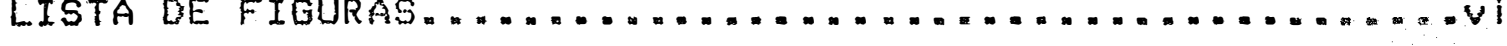

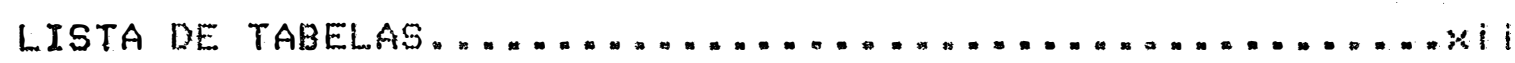

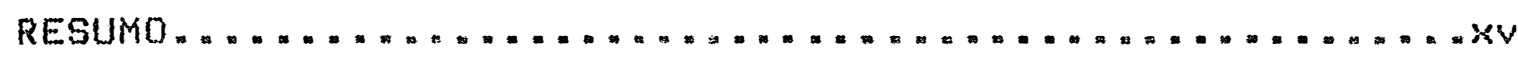

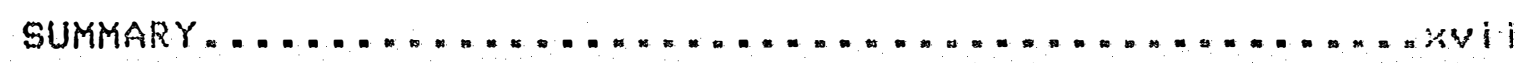

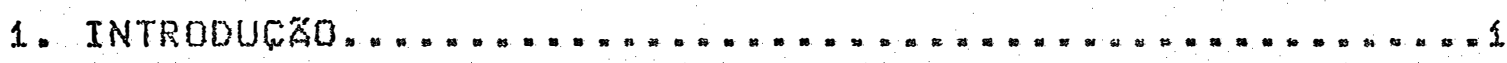

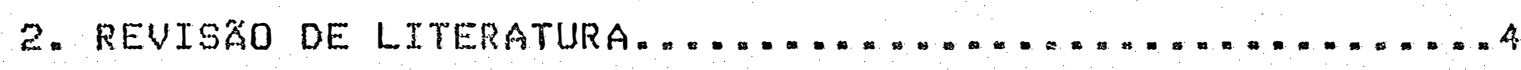

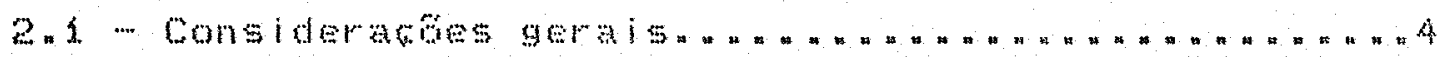

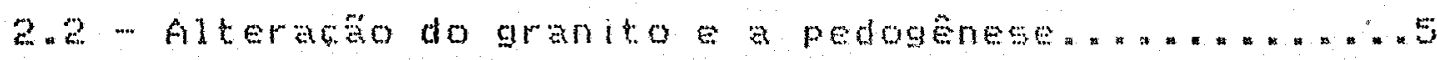

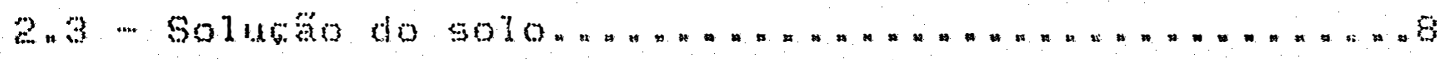

2.4 - Aspectos termodinântos ex ipos geoguimicos da

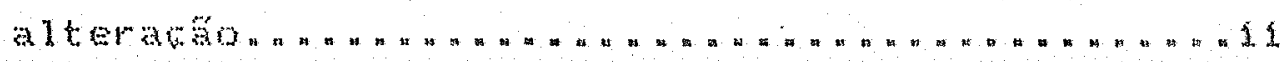

3. MATERTAL E METODOS...

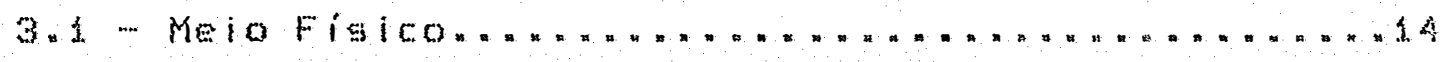

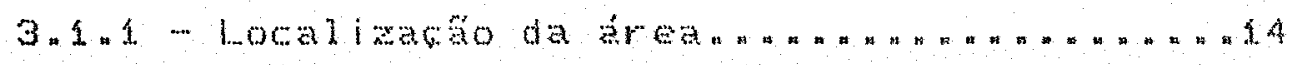

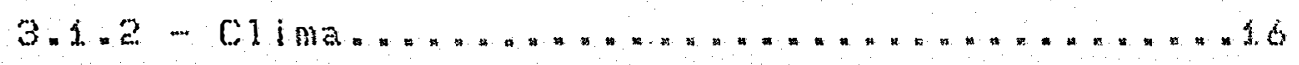

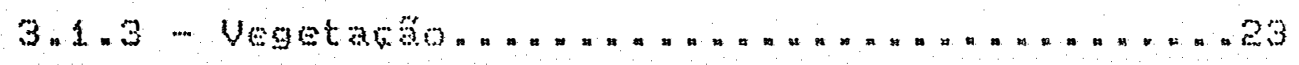

3.1.4-Geologia getrotogia.................

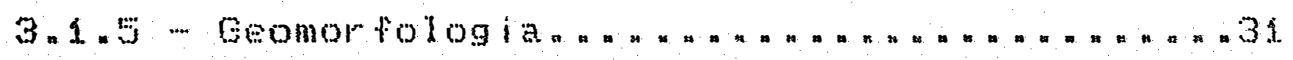

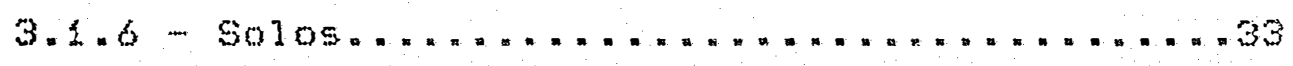

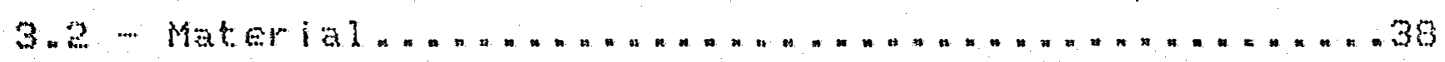

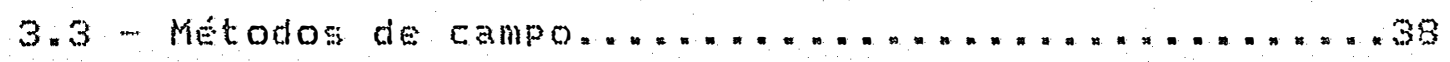

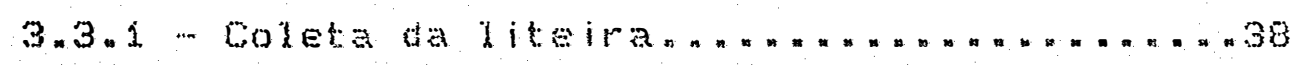

3.3 .2 . Coleta de solo e arena....................

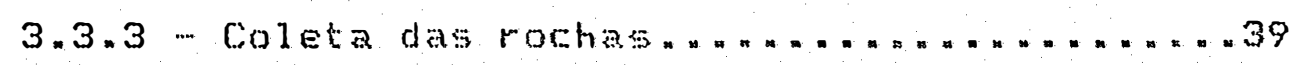

3.3.4 - Coleta da água da fonte..............40 


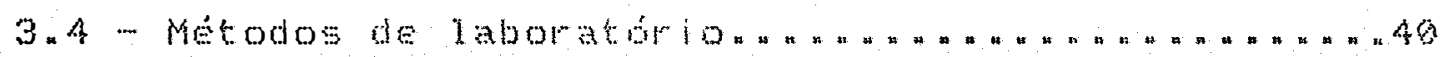

3.4 .1 - Extragáo da soluga do solo..... . .......40

$3.4 .2-A n d i s e s$ fisicas do goloe arenann.....43

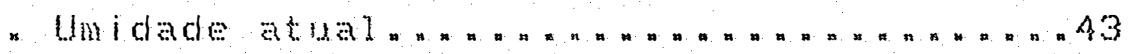

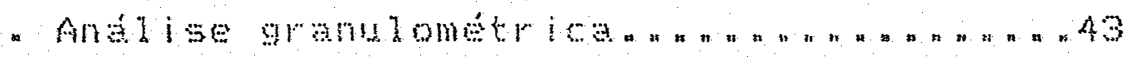

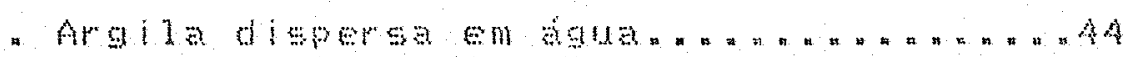

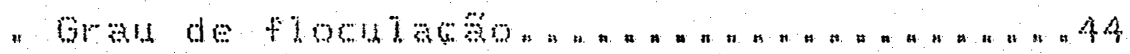

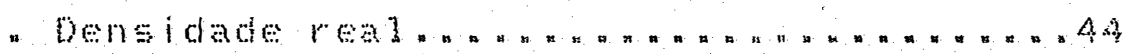

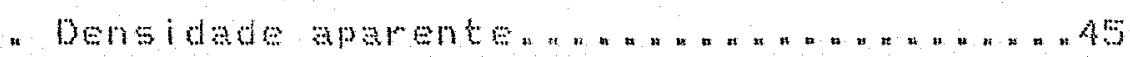

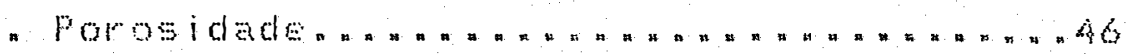

"Facionamento gramulometrio da materia

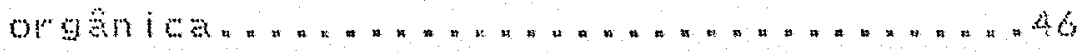

3.4.3 -. Ana d ises anicas das anostros de solo

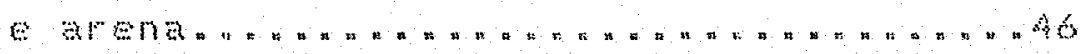

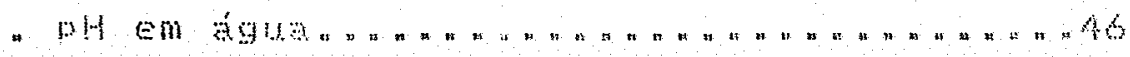

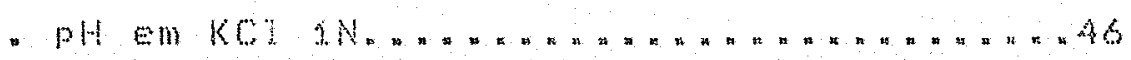

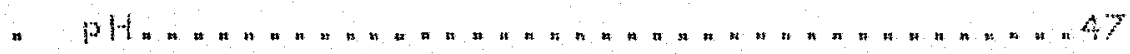

- Carbonototal $1 \ldots \ldots \ldots \ldots \ldots \ldots \ldots \ldots \ldots \ldots \ldots \ldots \ldots \ldots 47$

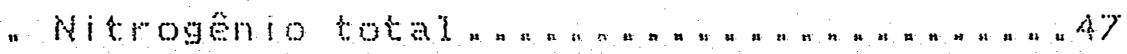

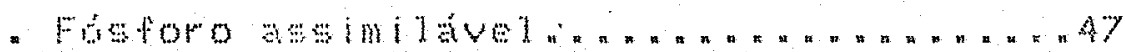
be $+2++$

- $\mathrm{Ca}, \mathrm{Ma}, \mathrm{Na}, \mathrm{K}$, trocáveis.........Ay

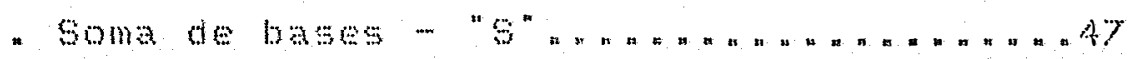

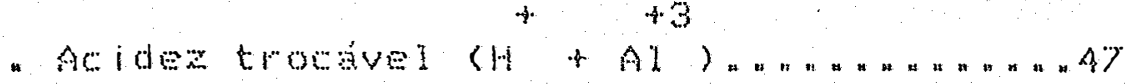
$+3$

- Al troeavel .....................48 $+$

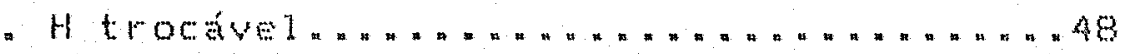

- Capacidade de troca de cations - "CTC" "Ag

. Saturata de bases .... "U\%" ".............48

3.4.4 - Analises quinicas da solura do $5010 . n_{\text {na }} 48$ 


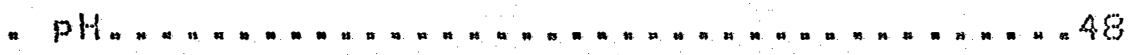

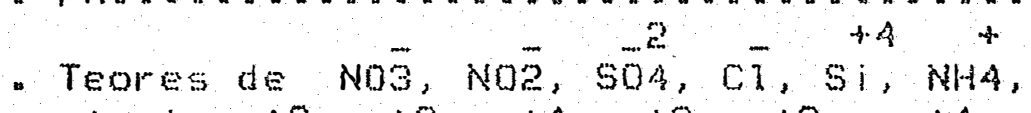
$+++2+2+4+3+2+4$ $\mathrm{Na}, \mathrm{K}, \mathrm{Ca}, \mathrm{Mg}, \mathrm{Mn}, \mathrm{Al}, \mathrm{Zn}, \mathrm{P}, \ldots .48$ 3.4.5-Balango ionico da solugádo do solo.....49 $3.4 .6-$ Anal ise kermodinamiea da solugäo do

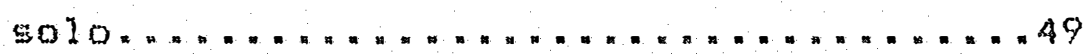

3.4 .7 .... Análi $i$ mineralógicas w....................49

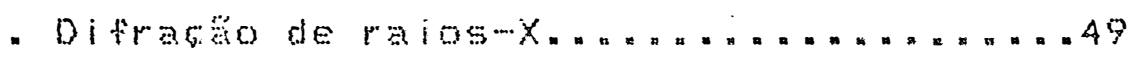

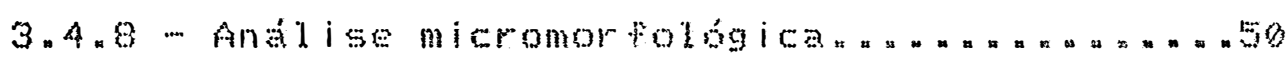

- Tmpregnagáco con resina e laminargon.

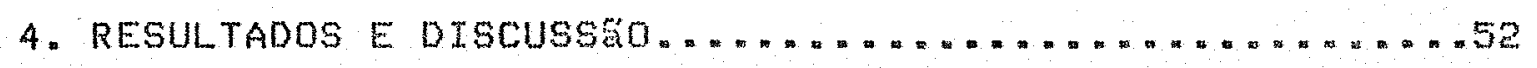

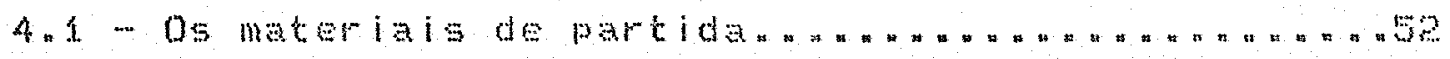

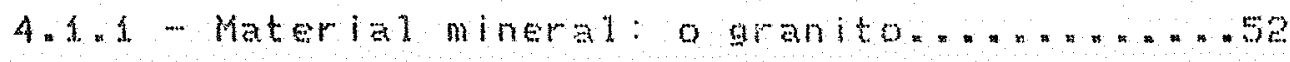
A.1.1.1 Gensese das arenas granitios e suas transformabes minera-

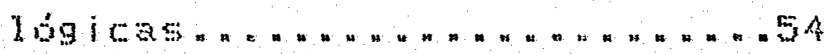
4.1.2 - Material orgânioo: biomasia aérea e liteiran.............58 4.1.2.1 - Evolugro dos constituintes organicos depositados no solo fela Iiteira............6

4.s-Prodseo da evoluga mineral e organica: $055010 \ldots \ldots \ldots \ldots \ldots \ldots \ldots \ldots+\ldots \ldots$

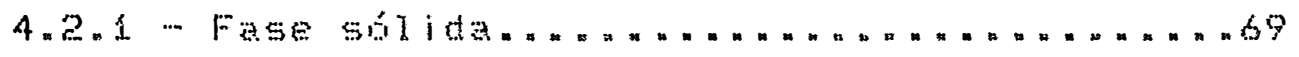
4.2.1.1 - Morfologia...............68 $4.2 .1 .2-$ Micromorfologia.............. 4.2.1.3 -. Mineralogia...............85 
$4.2,4.4$ caracterieticas fisicas.......96

4.2.1.5- Caracteristicas químicas..... tis

4.2 .2 Fase liquida - 5014580 do 5010........ 134

4.2.2.1 - Composizo quimica da soluco

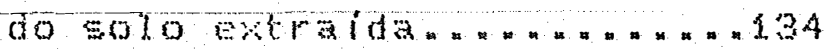

- Nitrato........................\$40

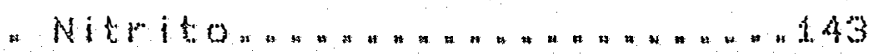

"Amoñon

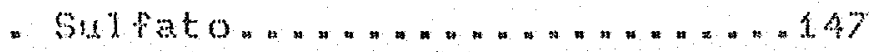

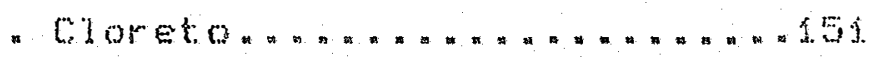

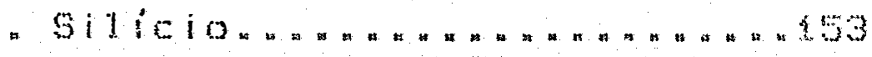

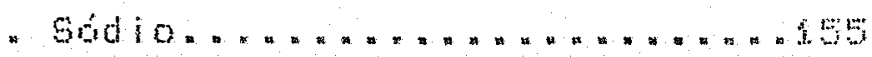

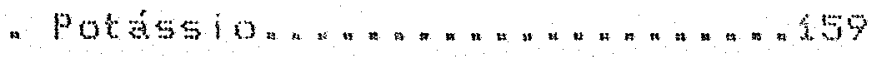

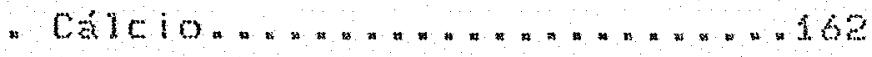

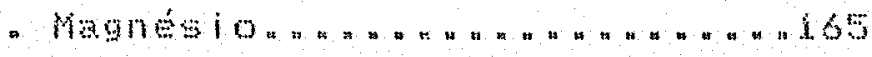

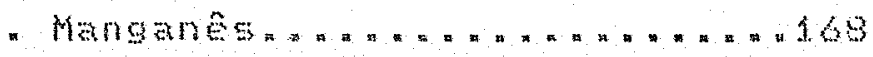

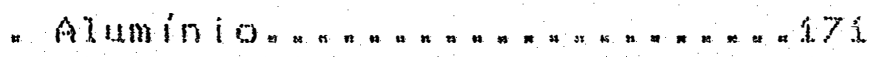

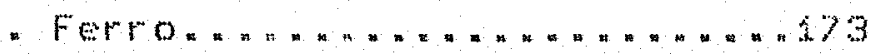

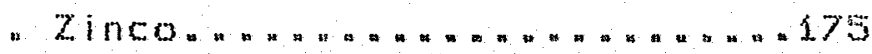

- Fotsoro...................

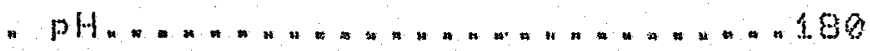

4.2.2.2- Balango innico da solugáo do

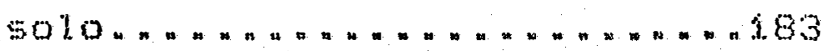

4.2.2.3- Estudo termodinamito da 501460 do $5010 \ldots \ldots \ldots \ldots . . . . .193$

4.2 .2 .4 Água da fonte..............204 


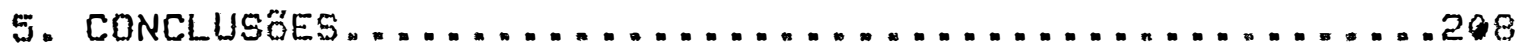

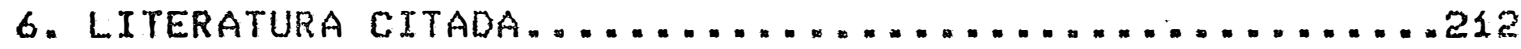

7. APENDICE, ........................................... 


\section{LISTA DE FIGURAS}

1 - Mapa de losalizacoro da área de estudo e a distribuicato espacial do granito reles pires.......s.s

2 - Tipos de climas segundo a classipicacäo de Koppen. Fonte: Projeto RADAMBRABIL . \$980.....................

3 - Distribuicáco da precipitacátobal media andal (mm)

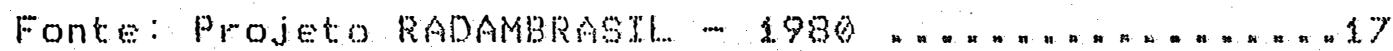

4 - Ritmo mensal do balango hidrico da estacto meteorologica de Vera - bleba celeste - Mr e de Cachimbo - MT, sesundo Thornthwate e Mather 1995 , n

5 - Distribuicäo espacial das temperaturas medias anda is (oc), da regito estudadan Fonse: Projeto

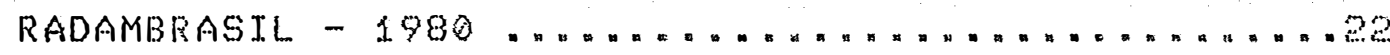

6 - Jndice de umidade de Thornthuate, da regian estudada. Fonte: Projeto RADAMBRAsTl ... $1980 \ldots \ldots . . .22$

7 - Mapa da cobertura vegetal da regiäc estudada. Fonte: Projeto RADAMBRASTL $1980 \ldots \ldots \ldots \ldots \ldots . . . . . . . .24$

8 - Mapa geologico da regiäostudada. Fonte: Projeto

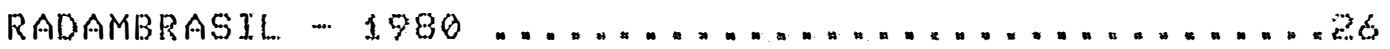

9 - Mapa geomorfolbgico da regiăo estudada. Fonte:

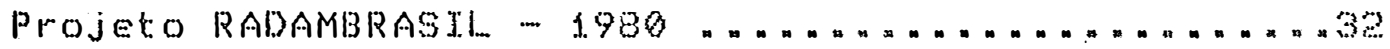

10. Mapa de solos da regiäo estudada. Fonte: projeto

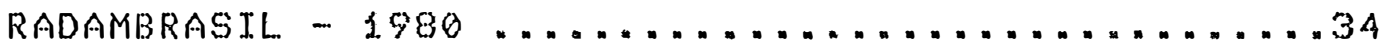

1. - Esquema do cilindro de compressáo fabricado para a

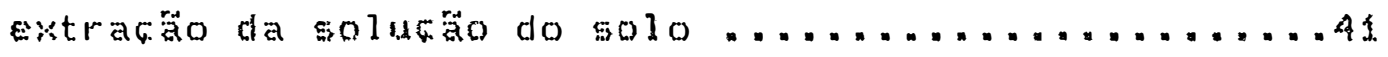

12. - Distribuigäo em profundidade dos teores de Carbono 


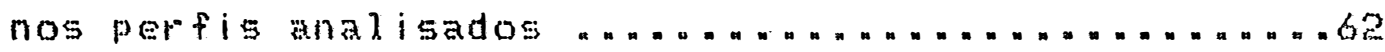

13-Distribuicáo en profundidade dos teores de Nitrogenio nos merfis analisados ..................63

14 - Corte esquematico da topossequencia NA E a local izaca dos perfis estudados ......................

15 - Perfil do solo cambissolo capacerizado como NÁ

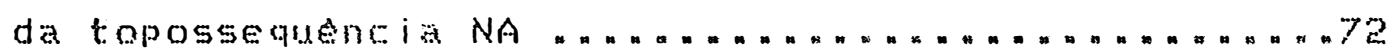

16- Perfil do solo cambissolo caracterizado como NA2

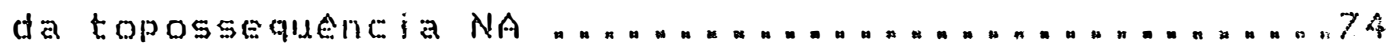

1.7 - Perfil do solo cambissolo caracterizado como Na3

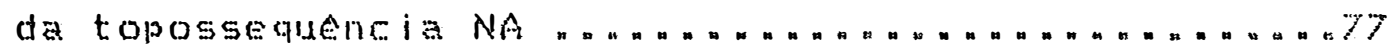

18 -Perfil do.solo cambissolo caracteriado como NBd da topossequancia NB "

19 - Difratogramas de raios-x da fraço silate das amostras de solo e arena coletadas en diferentes profundidades no Perfil NAz ....................

20 - Difratogramas de raios $x$ da fracáo silte das amostras de solo e arena coletadas em diferentes

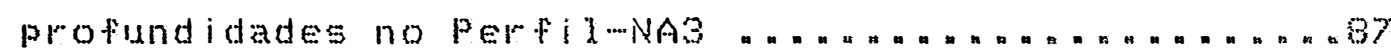

21 - Difratogramas de raios $-x$ da fracto sile das amostras de solo e arena coletadas em diferentes

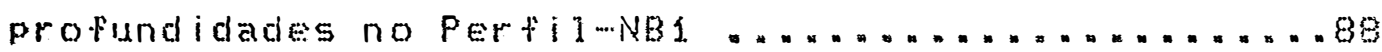

22 - Difratogramas de raios $x$ da fraca argila $e$ eilte das amostras de solo e arenas coletadas em diferentes profundidades no Perfil NA1............89

23 - Difratogramas de raios $-x$ da fracăo argila das amostras de solo e arena coletadas en diferentes

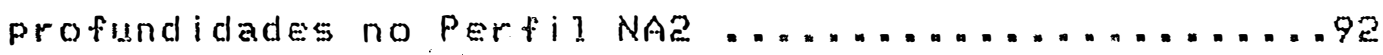


24 - Difratogramas de raios $x$ da fracáorgila das amostras de solo e arena coletadas em diferentes

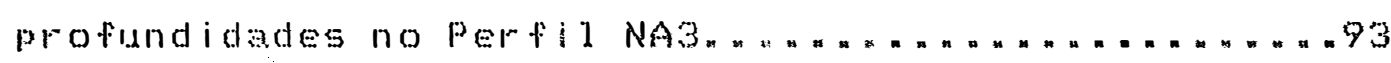

25 - Difratogramas de raios $-x$ da fááco argila das amostras desolo e arena coletadas em a iferentes profundidades no Perfid NBt ...................... 84

26 - Distribuiráo em profundidade dos percencuats da fracáo areia grossa (2- 0 , rmm) nas amostras de

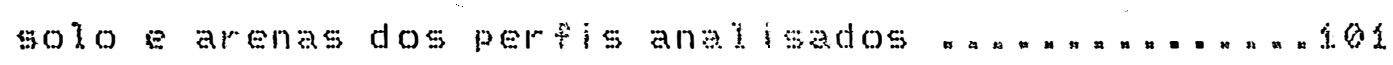

27 - Distribuitao en profundiable dos percentuais da fracáco areia fina (0,2-0,05m) nas amostras de

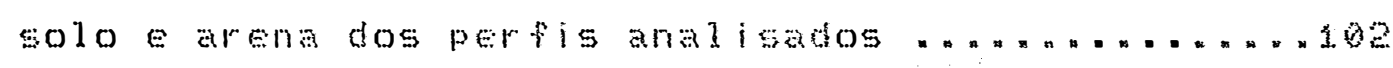

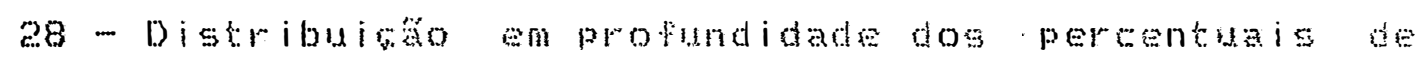
silte $(0,05-0,002 \mathrm{~mm}$ nas amostras de 5010 e

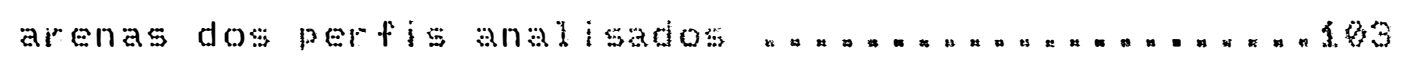

29 - Distribuica en profundidade dospercentuais da

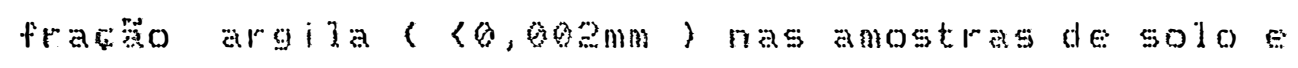

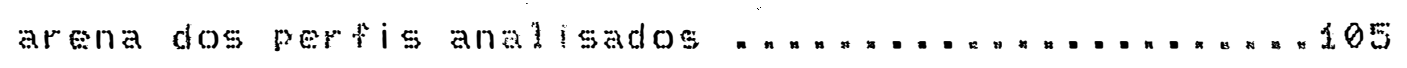

30 - Densidade real e aparente em profundidade nos pertis analisados ................................. 08

31 -. Porosidade do solo em protindidade nos pertis

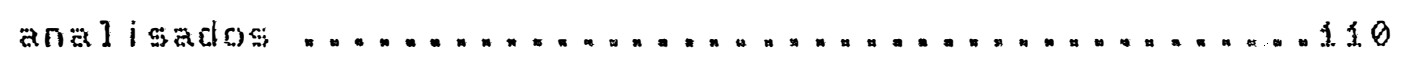

32 - Teores de calcio nas amostras do solo e arena dos

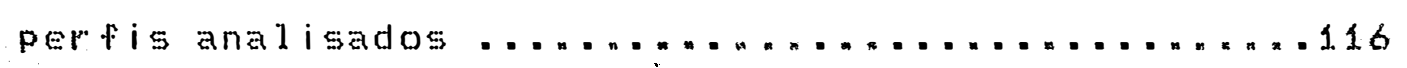

33 - Teores de magnesio nas amostras do solo e arena dos pertis analisados ............................

34 - Teores de sidio nas amostras do solo e arena dos 
pertis analisados n . . . . . . n . . ... . . . . . . . . . . 122

35 - Teores de potássio nas amostras do solo e arena

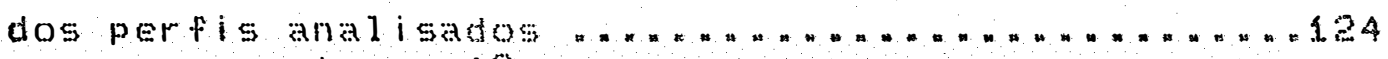

36 - Valores de H e Al nas amostras do soloe da arena dos pertis anal isados ...................... nag

37 - Valores de pH (HeO) e pH (KCl) nas amostras do solo e arena dospertis analisados ...............33

38 - Distribuica en profundidade dos teores de nitrato na solucho extraida das amostras de solo e arena

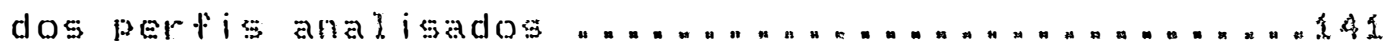

39 -. Distribuifäo en profundidade dos teores de nitrito na solucia extraida das amoseras de solo a arena

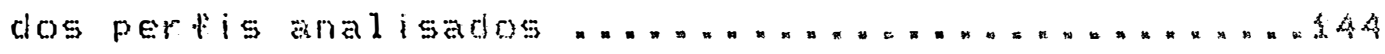

40 - Distribuicáno em profundidade dos teores de amonio na soluca extraida das amostras de solo e arena

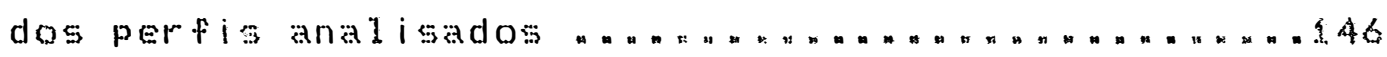

41 - Distribuiféo en profundidade dos teores de sulfato na solucáo extraida das amostras de solo a arena dos perfis analisados ............................443

42 - Distribuiga em profundidade dos teores de cloreto na solucio extraida das anostras de solo e arena

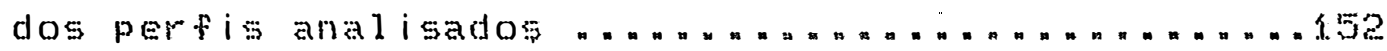

43 - Distribuicéco em profundidade dos teores de silicio na solucáo extraida das amostras de solo e arena dos perfis analisados .......................

44 - Distribuigáo em profundidade dos teores de stidio na solucáo extraida das amostras de solo e arena 


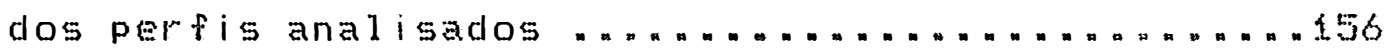

45 -.. Distribuigäo en profundidade dos teores de potássio na solugáo extraida das amostras de 5010

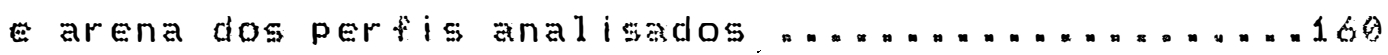

$46-$ Distribuicáo en profundidade dos teores de caldo na solugáo extraida das amostras de solo e arena

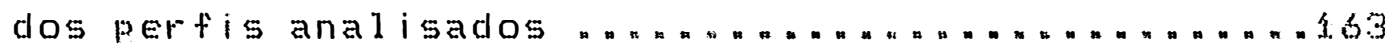

47 - Distribuigáo em profundidade dos teores de magnésio na solugáo extraída das amostras de solo e arena dos perfis anal isados ................66

48 - Distribuitá en profindidade dos teores de manganês na solucäo extraida das amostras de solo

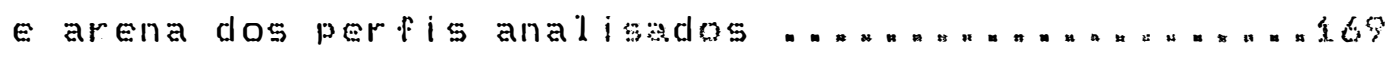

49 - Distribuicäo em profundidade dos teores de alumínio na solucoso extraida das amostras de 5010 e arena dos perfis anal isados . . . . . . . ........... ste

50 -- Distribulä́o em profundidade dos teores da ferro na solugáo extraida das amostras de solo e arena

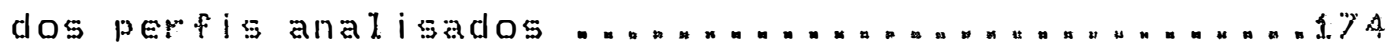

51 - Distribuicäo en profundidade dos teores de zinco na solucáo excraida das amostras de solo e arena dos perfis anal isados .............................

5e - Distribuicáo en profundidade dos teores de fósforo na solufäo extraida das amostras de solo e arena dos pertis analisados .............................. 79

53 - Distribuigäo en profundidade dos valores de pH na solucáo extraida das amostras de solo e arena dos perfis analisados......................... 81 
54 - Diagrama da estabilidade dos minerais neoformados $+2+1+$ em funcáo da concentraba dos ions ca , K, Na sion e valores de pH a a 250 e 1 atm r na solucáo de solo e arena de um solo cambissolowpertil NAt....99

55 -. Diagrama da estabilidade dos minerais neoformados en funcáo da concentrako dos ions $\mathrm{Ca}, \mathrm{K}, \mathrm{Na} \mathrm{e}$ sioe e valores de pH ( a 25oce 1 atm) na solutáo de solo e arena de um solo cambissolowpetil NA2. .200

56 - Diagrama da estabilidade dos minerais neoformados em funcáo da concenorazo dos ions ca , $\mathrm{K}, \mathrm{Na}$ giose valores de PH ( a 2500 es atm) na solusa de solo e arena de um solo oambissolowperti Nän.

57 - Diagrana da estabilidade dos minerais noformados em funcaro da concentragto dos ions $\mathrm{Ca}, \mathrm{K}, \mathrm{Na} e$ sion e valores de pH ( a 2500 e 1 an) nasoluce desolo e arena de um solo cambissolompertil NBt. . noe 


\section{LISTA DE TABELAS}

1. - Balanco hidrico da Estacäo de Cachimbo-mt, segundo Thornthwate \& Mather (1955). Fonte: Projeto

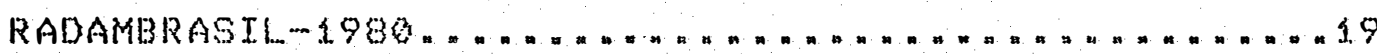

2. Balanco hídrico da Estacáo de Vera-Gleba CelesteMT, segundo Thornthwaite s Mather (1955). Fonte:

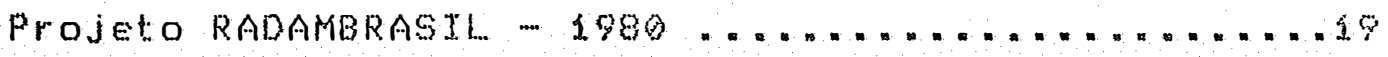

3 - Teores de Carbono e Nitrogenio nas amostras de

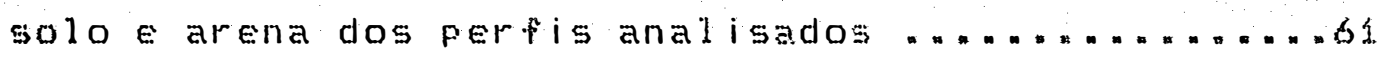

4 - Fracionamento granulométrico da mária orgânica das amostras de solo correspondente aos perfis

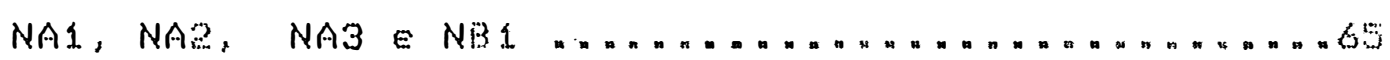

5 - Percentagen de carbono kotal e carbono caleulado atraves do fracionamento granulometrico da M. $M_{n}, \ldots$. 67

6-Distribuitáo granulometrica das particulas na fracáo< $2 \mathrm{~mm}$, densidade real, densidade aparente e porosidade das amostras de solo e arena dos

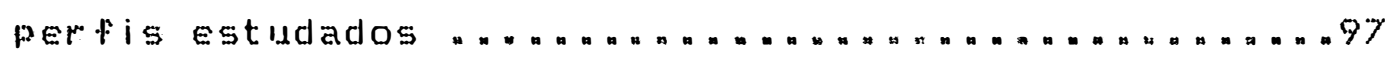

7 - Complexo Sortivo, soma de bases $(S)$, capacidade de troca cationica (cte), indices de saturacio de bases ( $\% U)$, PH (H2O) e PH (KCI) das amostras de solo e arena dos pertis estudados n..................13

8 - Teores médios (mg/l) em profundidade dos íons na solucaro de um solo cambissolo sobre um macioo granitico de Terra Nova do Norte en Mato Girosso-

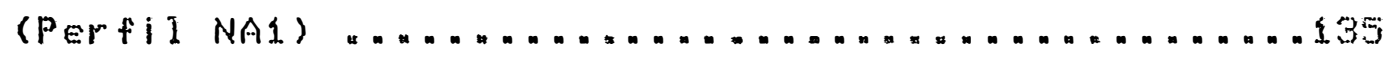
9 - Teores médios $(m g / 1)$ en profundidade dos ions na 
solucăo de um solo cambissolo sobre um macico granitico de Terra Nova do Norte em Mato Grosso -

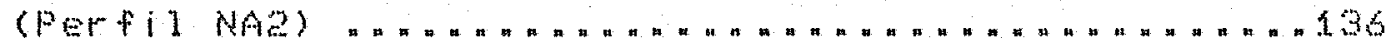

10 -.. Teores médios (ma/l) em profundidade dos íons na solucio de um solo cambissoto sobre um macioo granitico de Terra Nova do Norte em Mato orosso-..

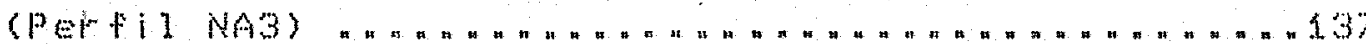

1. - reores médios (ma/l) em profundidade dos fons na soluç艹o de $4 m$ solo cambissolo sobre um matco granitico de Terra Nova do Norte em Mato orosso (Perfil NB1) w, nn "

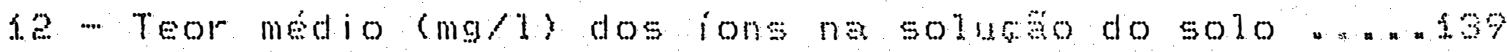

13 - Teores médios $(\mu$ mol/1 $)$ em profundidade, dos ions na solucáto do solo e arena para o balango

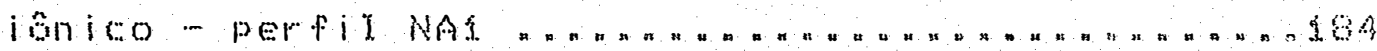

1. - reores médios $(\mu$ mol/l) en profundidade, dos ions na solucáo do solo e arena para o balanco

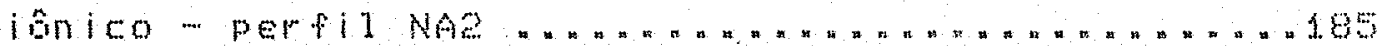

S. - Teores médios ( $\mu$ mol/ ) en profundidado, dos ions na soluba do solo e arena para o balanco

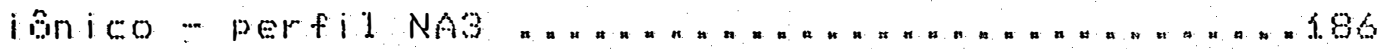

16 - Teores medios ( $\mu$ mol/l $)$ em profundidade, dos ions na solucäo do solo e arena para o badanco

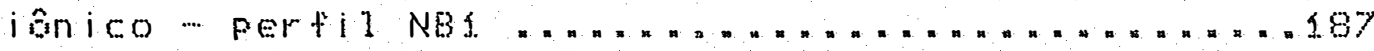

17 - Badanco iônico da solucádo solo e arena extraida das amostras de um solo cambissolo sobre um macico granitico de Terra Nova do Norte-mT - perfil Nán a 188 
18 - Balango isnito da solucäo do solo e arena extraida das amostras de um solo cambissolo sobre um macico granitico de Terra Nova do Norte-MT - perfil NA2. - 199

19 - Balanco ionico da solugäo do solo e arena extraida das amostras de um solo cambissolo sobre um maciso granitico de Teria Nova do NortemT - perfil NA3...196

20 - Balanso ionico da solucäo do solo e arena extraida das amostras de um solo camb issolo sobre um maciso granitico de Terra Nova do Nortem - perfil NB1. w. 191

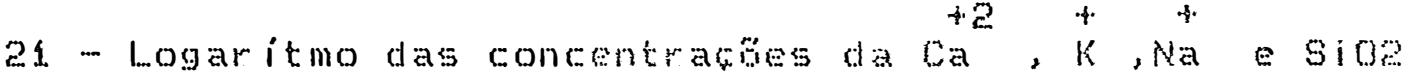
para a elaboracáo dos diagramas de estabilidade dos minerais sob o ponto de vista termodinamico -.

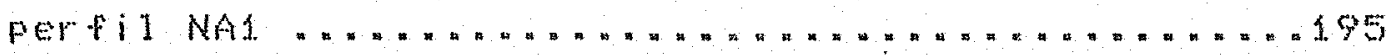

22 - Logaritmo das concentrabes da da, K, Na s sios para a elaboracáo clos diagramas de estabilisade dos minerais sob o ponco de vista termodinamió-

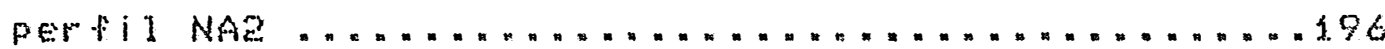
23 - Logar itmo das concentrabes da Ca , $\mathrm{k}$, Na esop para a elaboracáo dos diagramas de estabilidade dos minerais sob o ponto de vista termodinâmico...

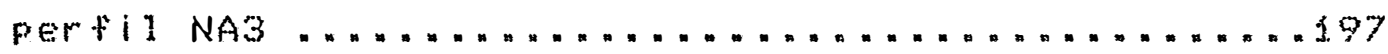

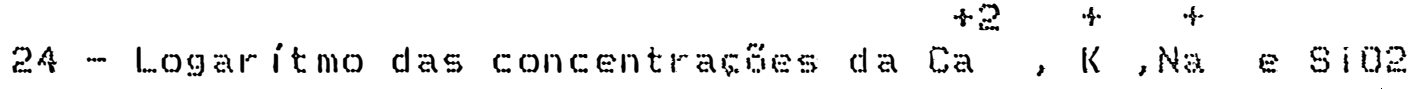
para a elaboracäo dos diagramas de estabilidade dos minerais sob o ponto de vista termodinâmico-

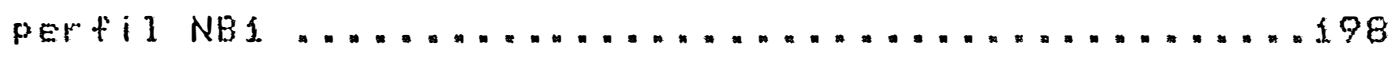


"caractertzagóo das fases sólida E liquida de solos E ARENAS DERIVADOS DO GRANITO SOB FLORESTA TROPICAL AMAZONICA (TERRA NOVA DO NORTE - MT)"

Autor: NILTON TOCICAZU HIGA Orientador: PROF. DR. CARLOS CLETENTE CERRT.

RESUMO

Com o objetivo de caracterizar as fases solida e liquida das arenas solos derivados do granito sob floresta tropical amazonica da regiă da serra formosa no municipio de Terra Nova do Norte. Norte do Estado de Mato Grosso, foram coletadas, en duas topossequencias, amostras de solose arenas de cambissolos desenvolvidos "in situ". Uma parte das amostras foi submetida à prensagem num cilindro de compressáo para a extraço da solucăo do solon As análises da fase sbida permitiram identificar que esses solos sao distroficos, ecom teores de ate $65,5 \%$ de areia. 05 difrabogramas de raios $-x$ denotam que a mineralogia da fracäo argila dominantemente constituida pela caolinita, seguida fela gibbeita, mica quartzo. As andises micromorfologicas permitiram 
identificar a presenat de minerais primarios alteraveis como a microclina, plagioclásio e a biotita, desde os hor izontes superficiais desses solos caracterizandowos como cambis5010s.

As ana 1 ises de fase líalda denotam que as solucbes săo ricas en cations mono e bivalentes, conferindo valores de pH neutro nos horizontes superficiais e ligeiramente alcalino nos horizontes mais profundos. Altos teores de nitrato na soluza dos horizontes superficiais refletem alta taxa na mineralizacio da materia organia constantemente depositala no solon A distributäo en profundidade dos teores dos ions na soldara dos solos a arenas, demonstra a atividade da biomassa miorobiana nos horizontes superficiais e a acao do intemperismo do material de origem nos horizontes mais profundos. As mécias por perfil, dos teores dos ions $504,5 i$, mi $i^{2}, F e$ rew fletem suas migrabies promovidas pelo fiuxo lateral da água. Os maiores teores de $\mathrm{Na} e \mathrm{~K}$ na soluzaro do pertid NA1, denotan o fornecimento ativo desses ions a partir da alteracáo dos feidspatos do granito subjacente. os diagramas de estabilidade dos minerais denotam que as

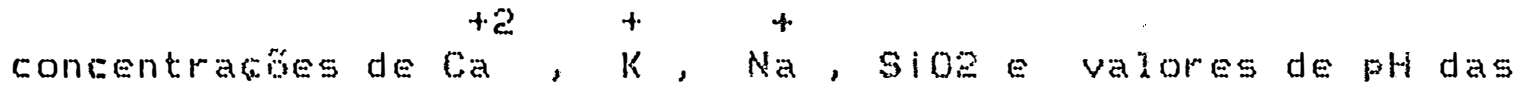
solucbes (a asoc e 1 atm), propiciam a neoformafáo de minerais que se concentram na zona de estabilidade da caolinita com alguma tencencia à zona de estabilidade da gibbsita. 
"characterization of solid and liquid phases of soils and ARENAS DERIUED FROM GRANITE UNDER AMAZON TROPICAL FOREST (TERRA NOUA DO NORTE - MT) *

Author: NILTON TOETCAZU HIGA

Adviser: PROF. DR. CARLOG CLEMENTE CERRI

SUMMARY

With the objective of wharacteriaing the liquid and solid phases of "arenas" and soils derived from granite under Amazon tropical forest of "Serra Formosa", on Terra Nova do Norte municipalits, north of state of Mato Grosso- Brasil, soil and "arena" samples aere collected from two toposequencies of cambisols developed "in situ". Part of the samples was submitted to compressions in cylinder for solution extraction.

The analysis of solid phase data showed that soils are distrophic and with sand contents up ro $65,5 \%$. X-ray difractograms indicate that the mineraiogy of the clay fraction is dominantly constituted of kaolinite, followed by gibbsite, mica and guartz. Micromorphological analysis showed the presence of alterable primary minerals such as microcline, plagioclase and biotite, even at the 
superficial horizons of these soils, characteriaing them as c. ambisols.

Analysis of the liguid phase indicated that the solutions were rich in mono and divalent cations, determining neutral values of pH in superficial hortzons and wightly alcaline in deeper horizons. High nitrate contents in soil solution of superticial layers reflected the high mineralization rate of organic matter, which is constantly deposited on the soil. The distribution in depth of the ion contents in soil and "arena" solution, demonstrated the microbial biomass activity ot superficial hor ixons and the action of or ginal material weathering in deeper lasers. The profile averages of Sot, $\mathrm{A}$, Al, Fe ions reflect their mistations promoted by lateral water find. The greater contents of $N a$ and $K$ in the solution of NAs profile, show the active feeding of these ions from the alteration of subjacent granite rejaspate. The stability diagrams of the minerals indicate that concentrations of

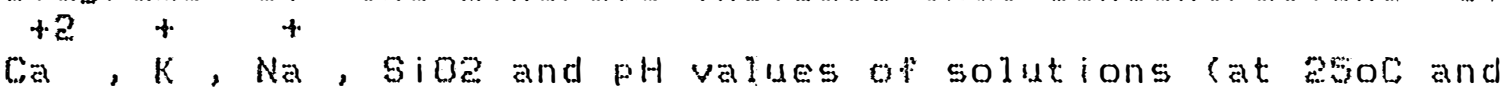
1 atm) promote the development of minerals that are found in the kaolinite stability zone, with some tendency to the gibbsite stability 


\section{INTRODUCÃO}

Os estudos sobre intenperismo de rochas graniticas e a pedosênese, realiandas nos mais diferentes niveis de detathe, a exemplo dos trabalhos de MELFI (196), CERRI (3979) e diversos outros trabithos sobre adterabose pedogênese sempre detiveram a fase silida do complexo de alterazo. Assim sendo, a sua fase liguda, ou a soluckodo solo, normalmente éexeluida dos estudos de alteracío e da pedogenese. Tal fato constitui uma lacuna com termos de evolucäo en novos contecimentos sobre os processos pedogenét icos.

Portanto, o presente trabalhotem como objetivo geral, estudar as caracteristicas das tases sólidas e liquida de solos e arenas de canbisgolos desenvolvidos "in situ" e derivados do granito sob floresta tropical amazónica.

Como objetivos especificos foram propostos:

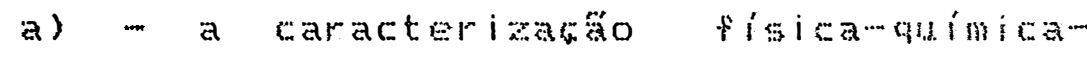
mineralbica e micromorfolbica dos solos e das arenas;

b) - a caracterizaga moditativa e quantitativa dos ions da solugäo do solo e a distribuicäo dos seus teores em profundidade;

c) - definir através da construgáo de diagramas de estabilidade e da concentragáo dos ions da solugáo do solo, a zona de estabilidade dos minerais secundários neoformados;

d) - definir as formas e as intensidades 
de mobilizaçón exportacáo dos ions na solucaro do solo; Ds aspectos fundanentais desses objetivos consistem na obtençáo de parâmetros que permitam ayaliar o nivel de interferencia da solugáo do solo na evoluắo dos processos pedogeneticos, e tambeim observar, o nivel de interferência da fase liquida sobre os processos dinâmicos na translocacio dos alementos provenientes da alteracáo dos minerais frimários, tanto no perfil de alteracáo rem profundidade) como também, nas topossequencias selecionadas. Portanto, a inovacäo a contribuicáto mator deste trabalho, consiste na obtencé dos parametros retronencionados, sob a influencia do clima tropical dinido agressivo numa regiöo com fooresta amañonica ativa gue anda näo sofres nenhuma influencia antrobica e apresenta ciclagem rapida e significativa dos minerais nutrientes, fornecendo uma quantidade significativa de liteira ao solo.

$$
\text { Para atingir esses objetivos, form }
$$

selecionados quatro perfis de solos canbissolos, isto porque, a acăo maxima do intemperismo se verifiea nos solos nais rasos contendo arenas, graniticas por sua vez, o granito proporciona certa facilidade de escudo em funcaso da sua granulacăo grosseira equigranular.

Năo se trata de um trabalio completo, pois a quantidade de solucăo extraida das amostras de solos e arenas foi insuficiente para realizar a caracterizacăo e a quantificagáo de todos os ions constituintes da mesma. Portanto, existiram duas linitacies maiores neste crabalio as qua is for an: 
a) - a pequena quantidade de solugáo extraida das amostras de solos e arenas;

b) - a impossibilidade de retorno ao campo para coleta de amostras en épocas distintas con o objetivo de obter as variabos nosperiodos en que há excedente de água no solo. 


\section{REVISÃO DE LITERATURA.}

2.1 - Considerabges gerais.

Segundo PEDRO (1969), a alterafo das rochas oristalinas que aftoram na superficie do globo, representa um tenomeno observado pela primeira vez em 1833 na Franga por J. FoukNet e que a partir desta epoca, a idéia da alteracáo das rochas aflorantes sob a acáo dos agentes atmosfericos, torna se relevante entre os mineralogistas, citando como exemplo, os trabaltos SLCESEIVOS de FORSHAMMER (1934), BRONGNTART (1839), MALAGUTT (184f), G BISCHOF (1947), ressaltando o de EBELMEN (1845 - f847) que reatianou o primeiro estudo detalhaso a partir de roctus de composicáo variada. Cita ainda, que tais pesquisas näo delinearam um principio diretor bem definido e que somente no final do séulo xux, en sabs, o mineralogista russo B. DokourchäU propis, durante um estudo sobre as terras pretas (tehernozen) da Ukrania, os fundamentos de uma nova ciencia, por ele denominado de "Pedologia", Marcando desta maneira, una segunda etapa na Evoluaro dos contrecimentos dos fenomenos superticiais.

A partir dai, a Evolugäo da ciencia do solo, tem se baseado fundamentalinente em novos conhecimentos sobre a dinamica e desenvolvimento das transfornacótes mineralógicas de roctras, arenas ou alteritas e do proprio solo, frente às aqöes do intemperisno. Como Exemplo, pode-se citar que foram realizados ate o presente momento, en diversos palses, inumeros trabahos cientificos 
relacionados ao estudo das alterafobs de diversas rochas, principalmente as granfticas.

2.2 - Alteracăo do granito e a pedogenese.

o que deve ser mencionado, segundo crepra

(1979), \& que os principais estudos pedogeneticos e de alteracbes assoriados as rochas granticas, foram realizadas, en sua grande maioria, nas regiós de clina temperado, tanto nos Estados Unidos, como principalmente na Europa, atraves da atuaçấo de pesquisadores franceses, gue estudaram exaustivanente os principais macigos granfticos da Franca e que atraves de mais de uma centena de trabalros cientricos chegaran a caracteriantrodas as etapas da alteracio da rocha, desde a formagéo das arenas, at a genese dos seus solos. Cita ainda que sob condisbes de clima tropical foram realizados pouco mais de uma dexena de trabalhos, quase todos concentrados no Continente Africano.

Em particular no Brasil, ainda segundo

CERRI (1979), o fato do substrato geologico ser constituldo por mais de $2 / 3$ de rochas cristalinas com dominancia espacial das graniticas, mito pouco se estudou sobre as transformagies mineralogicas a pedogenese a partir dessas rochas.

Objet ivardo caracterian e correlacionar o material proveniente do intemperismo (arena) de rochas granfticas e os solos desenvolvidos en cinco regiöes bioclimaticas distintas: i) quente e linida - floresta 
amazonica; 2) semi-arida quente - catinga; 3) sub-quente e sub-ámida - floresta tropical sub caducifbliai 4l subtropical ámida de altitude - floresta subtropical caducifoliar 5) temperado ámido-campos, CERRI (1979), realizou um trabalho sistenatico de coleta de informacöes sobre fenomenos intempericos e pedogeneticos que agiram sobre certos macicos graniticos, chegando às seguintes conclusöes principais:

$$
\text { a - a caolinita é o mineral secundario }
$$
que esta presente en todas as arenas, e esta associada gibbsita tanto no clima quente e dmido como no clima subquente e subúmido. No clima semi-urido e quente a caolinita encontrawe juntamente con a montmorionita, ilita e vermiculita. Nos climas subtropical dmido temperado ámido a cablinita este assobiada a interestratificado regular mica vermiculita e vermiculita

b - os minerais secundarios desenvolvidos na arena apresentam a seguinte filiata:

"Cl ima quente e ámido (regiấo Nowte):

Biotita -->Vermiculita -..->Caolinita

Biotita $-\cdots+\cdots$ Caolinita

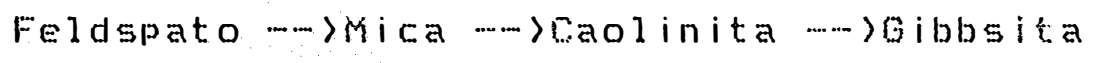

Feldspato $\rightarrow->$ Caolinita $-->$ Gibbsita

- Cl ima semi-árido e quente (regiro Nordeste):

Biotita - >Parabiotita $->$ Caolinita

Feldspato $-\cdots>$ Caol inita

. Clima subquente e subúmido (regiăo sudeste):

Biotita $->$ Clorita $->$ Parabiotita $->$ Caolinita 
Biotita --jparabiotita $-->$ Caolinita

Feldspato $-->$ Caolinita

- Clima subtropical únido de altitude cregi

Sudestel.

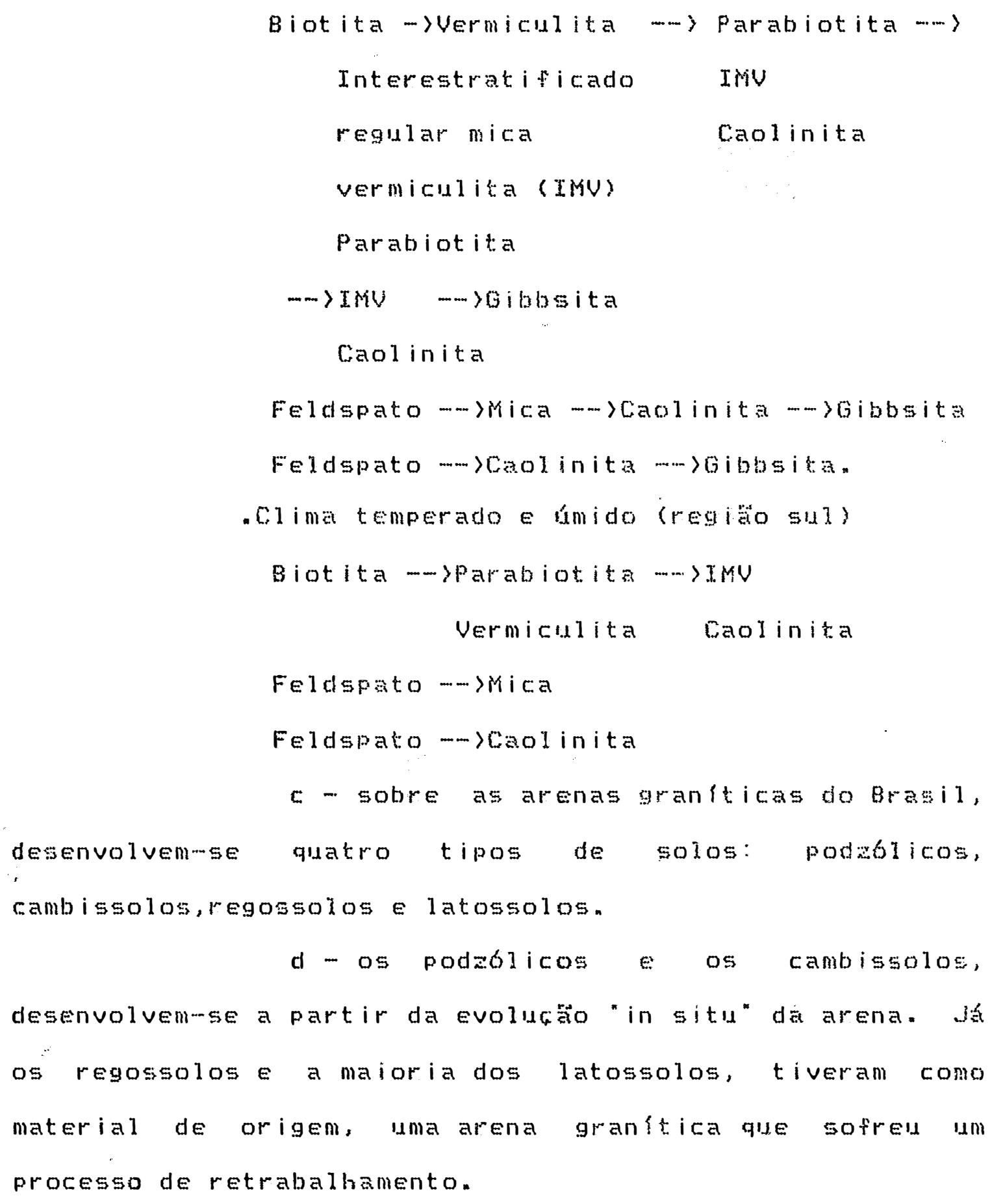


uma alteragäo superficial dominantemente hidrolitico, pode apresentar dois grandes "tipos de evoluzäo" sendo que o primeiro, decorrente de uma hidrolise moderada, é a arenizacăo e, E encontrada principalmente em regiöes extratropicais, principalmente nas zonas temperadas, como tamben, nas aonas frias ou aridas. Ja, o segundo tipo resulta de uma hidrolise mais intensa, sendo caracteristica das regiöes intertropicais e denominada de alteracăo laterftica, conforme citou CEPRI (AY7A).

A arenizatäo ta tom fenomeno que se caracteriza pela desagregatäo sotal da rocha en seus constituintes originais, sendo de ocorrencia comu e caracteristica das regibes temperadas, porem é batante raro nas regibes de clima tropion bmido, onde a agressividade dos agentes de intemper ismo provoca acentrato rearranjo mineralbgico e a neogenese em grande quantidade de minerais argilosos (CERRT - 197A).

\section{3 - Solucä́o do 5olo}

A soluG:Bo do 5010, segundo BRADY (1979), E apenas água do solo em aue foran dissolvidos as formas iônicas dos nutrientes vegetais. observa ainda, que nen sempre a soluräo do solo écontinua e tampouco se move livremente no solo, como também, é excessivamente mutavel, variando tanto no volume, quanto na proporcáo e quantidade dos seus componentes soluveis.

Já, segundo pearson (1971), citado por MALAVOL...TA (1976), a solugro do solo é definida como: "uma 
solugäo de eletrólitos quase em equilibrio que ocorre no solo en condicóes de näo satur acăo de umidade.

Una das importantes caracteristicas da solugấo do solo, segundo BRADY (1983), citado por BULL (1988), é a sua reacáo, pois os microorganismos e os vegetais superiores sä́o demasiadamente sensiveis aos seus ambientes quimicos. Assim sendo, há muito tempo se concede realce à reacáo do solo e aos fatores a ela associados.

Por sua vez, Mal...AVOLTA (1976), apresenta as principais caracteristicas do conceito de solucäo do solo, como sendo:

1 - constitui una parte maior do fator de intensidade no fornecimento de nutrientes para as plantas;

$$
\text { a - é o meio para a matoria dos protessos }
$$

quimicos e biologicos que ocorrem no solo;

3 - é o meio principal para o movimento de materiais no solo.

MALAVOLTA (1976) E REICHARDT (1985) sal ientam que a solugaro do solo possui composiozo variavel devido à uma série de processos dinâmicosentre as fases solida e liquida do solo, absorqua de nutrientes pelas raizes e seu subsequente transporte para a parte aerea das plantas. BRADY (1979) observa também que a solugáo do solo apresenta quantidades pequenas porén significativas de sais en solucáo, sendo que, muitos deles sáo essenciais ao desenvolvimento vegetal. Salientan tambén, que ocorre troca de nutrientes entre os solidose a solugáo do solo e, por 
outro lado, entre a solucão do solo e as plantas. A concentracáo de sais solúveis na solucăo do solo aumenta na medida en que se diminui por evaporacáo, o teor de água no solo. Num solo de regiáo dimida pode ocorrer concentracbes variáveis na solucáo do solo, de algumas partes por milháo até 30.000 partes por milhäo.

\section{A concentragäo das solugbes variam em} funcáo das modificacóes dos fatores do meio, prineipalmente pelas modificacbes sazonais do microclima (alternância de umedecimento e dessecacão). Oenriquecimento das solucibes do solo em cátions dissolvidos podem intervir, seja de modo natural, pela alteracäo dos minerais, ol pela decomposicăo da liteira liberando as bases, seja artificialmente, pela adubacáo mineral: nestecaso, o equilibrio modificado Pela troca de uma parte dos fons instoduzidos com alguns dos ions retidos pelo complexo de absorgáo. De maneira inversa, as solugbes do solo se empobrecem constantemente pela absorgáo das raizes ou pela lessivagem dos ions mais móveis: nesta condigáo o equilibrio se desloca no sentido de uma desabsorgáo parcial desses mesmos ions (DUCHAUFOUR -1.968).

A composigäo quimica das águas, segundo TARBY (1969), acusa as variabos climáticas e reflete a dinâmica sazonal no momento das amostragens. Assim, seus estudos, permitem distinguir a evolugáo atual das alterafies en que às vezes, o conhecimento dos minerais argilosos isoladamente näo suficiente para tais estudos. Ainda TARDY (1969), evidencia a necessidade imediata de um 
inventario das águas amostradas nas mais diversas regibes cristalinas en diferentes latitudes, o que permitira medir a influencia dos climas sobre o comportamento dos principais ions.

REICHARDT Et alii (1977), afirmam que um dos problenas abordados bá mu ito tempo por pesquisadores interessados na ciêneia dosolo, se refere ao problema da extraca e determinacáo da concentraxio ou atividade de ions, nutrientes ou quaisquer substañias na solugäo do solo, mas em funcío da complexidade do sistema solosolugăo do solo, nenhum resultado satistatirio foi apresentado ate hoje. Un dos métodos mais utiliados consta da agitacío de uma quantidade prédeterminada de 5010 com uma solugáo extratora, en dada proporsáo por determinado tempo. Este metodo tem merecido muitas criticas, porque envolve a completa destruicio do arranjo estrutural naturai do sistena poroso solowsolutáo do sola. Qutro método mais recente en que a solugáo do solo é extraida atraves do vácuo aplicado à uma cápsüa de cerâmica instalada no solo en determinada profundidade apresenta uma sirie de vantagens principalmente nos estudos que envolvem o cl- e o No3- que säo ions relativamente "livres" na solucä́o do 5010

\section{4 - Aspectos termodinâmicos e os tipos geoquimicos da alteragäo.}

Segundo MEDINA (1972), a importañcia da 
água no solo comeca a se evidenciar desde a origen do solo, considerando que a mesma constitui num dos mais ativos agentes de destruicáo e desagregacáo das rochas e seus minerais.

Segundo TARDY (1969) a água que circula nos perfis, transporta os fons liberado: pela hidrólise dos cristais en via de alteracäo. Assim, as condicoses do meio săo todas definidas pela concentragäo das solucbes comandando desta maneira a intensidade da hidrblise dos minerais primarios e proporcionando ac mesmo tempo que os ions liberados sejam engajados nas transformaçes ou nas neoformacies dos minerais secunderios. Em cada caso particular, tende mineral primario, mineral secundario solucăon

Com relacato aos tipos de evolucho do intemperismo e edogenese podewse afirmar que a composicato química e mineralbgica dos horizontes superficiais varia de acordo com as regiöes geograticas do globo, mesmo quando a alterafäo se desenvolve a partir de um mesmo tipo de rocha. Tais fatos foram constados a partir dos estudos de VINOGRADOU (1956) E VOLOBUEV (1962), todos citados por PEDRO (1969), os quais avaliaram a composica mo méta do SiO2, Al203 e Fe203 dos diferentes tipos de solos (correspondente a una espessura de un metro) e compararam sistematicamente ao teor determinado por CLARKES (1924) (tambem citado por PEDRO (1969)) para o conjunto das rochas eruptivas: $S$ iO2 $=59,09 \% ;$ A $1203=15,35 \% ; F E 203=7,29 \% ; \mathrm{K}$ $=5 \mathrm{iO2}$ total/A1203 $=6,6 ; \mathrm{Ki}=5 \mathrm{i} 02$ combinada/A1203 $=5,2$. 
Desta maneira, PEDRO (1969) salienta que tais estudos permitiran colocar en nitida evidencia, dois grandes tipos de evolusăo os quais serian:

a) nas zonas frias boreais, onde há dominância dos podzóis, o indice $K i=$ relaxăo molecular entre sios e AleOS dos horizontes superficiais é sempre superior ao valor que caracteriaa a rocha matriz, isto porque, a alteracáo conduz a um enriquecimento desses horizontes em silica.

b) en outras zonas, o indice Ki do solo inferior ao valor do mesmo indice na rocha matriz, isto porque, a alteracăo conduz a un empobrecimento dos seus solos ensioge, quanto mais se aproxima da zona cropical, maior é o empobrecimento, podendo en certos casos ser ben pronunciado, como é o caso da fornacăo dos bauxitos. 
3. MATERIAL E METODOS.

3.1 - Meio físico.

\subsection{1-Localizacăo da área.}

Esta pesquisa fol desenvolvida a partir das analises fisica, quimica e mineralogica de amostras de solo, arena e rocha coletadas en duas topossequencias de solos que se desenvolvem sobre um macico granitico da formacío Teles pires - Grupo vatumá, segundo o mapeamento realizado pelo RADAMBRASIL - 1980. A área localizange no Municipio de Terra Nova do Norte no Estado de Mato Grosso, na margem direita $e$ no quilsmetro 660 da rodovia BR - 163 no sentido Cuiab - Santarém. Mais precisamente a área apresenta as seguintes coordenadas: $55053^{\prime} 00^{\circ}$ de Longitude o. Gr. e $10020^{\circ} 00^{\circ}$ de Latitude sul, tendo a sua esquerda o Pio Teles Pires e ao Norte o Pio peixoto de Azevedo, respectivamente à 85 e 40 quilômetros de distância (Figura (2) )

A área encontra-se sob o dominio da Floresta Amazonica e se mantem ainda intacta com sua mata virgem, sem qualquer acáo antripica que descaracterize as condicbes naturais dos seus solos, mantendo assim, suas verdadeiras caracter isticas flsicas e qufmicas.

Trata-se ainda de uma área que apresenta um macico de rocha granitica bastante homogeneo com dominancia de minerais com granulara grosseira e sem indicios visiveis de metamorfismos a skemplo do que 


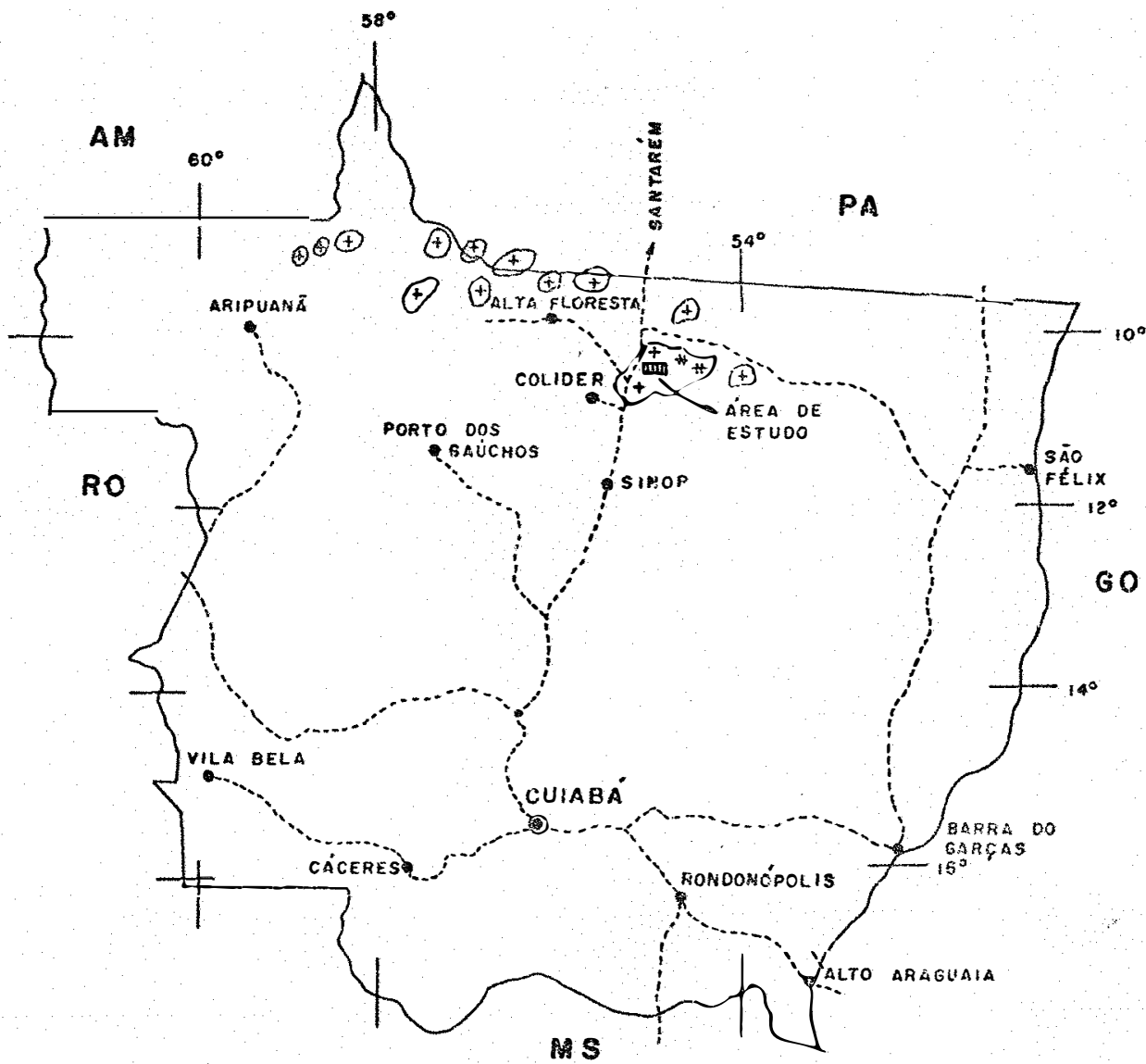

\section{LEGENDA}

AUIIII) ÁREA ESTUDADA

[++ $++_{+}^{+}$GRANITO TELES PIRES
ESCALA $=1: 6.000 .000$

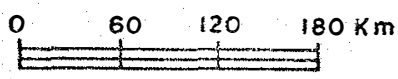

FONTE: PROJETO RADAMERASIL 1. 980

Figura bi - Mapa de localizara da área de estudo e a distribuicáco espacial do granito Teles pires. 
ocorre com o macico granftico de Săo Vicente localizado na Serra de Sắo Vicente a Sudeste de Cuiaba-Mr.

A opcäo por esta krea para o fim deste estudo desenvolvido se deve decorrencia deste macico de rocha granitica porque normaimente o granito apresenta vantagens sobre outras rochas en funce de alguns aspectos de relevancia, as quais seriam, segindo CERRI (1974):

i - as rochas graniticas além de cobrir cerca de $20 \%$ da superficie das terras emersas do globo, actram-se homogeneamente distribuidas por todas as anonas climaticas do mundo, o que permite interessantes pesquisas e correlacios;

i i - certas caracteristicas intrinsecas dos granitos tavorecem a observacio dos fenómenos de alteracăo, tais como a textura grosseira e a existencia de minerais com diferentes graus de alterabilidade.

$$
\text { 3.1.2-Clima. }
$$

0 dominio climatico regional \& do tipo Am - Clima Equatorial Quente Umido (figura $\theta 2$ ), com un pequeno periodo seco e chuvas com indices inferiores a $60 \mathrm{~mm}$ no mes ma is sECO (PROJETO RADAMBRASTL. 19801.

A pluviosidade média anual segundo PROJETO RADAMBRASI... (1980) E E levada na regiäo, estando limitada pelas isoietas de $2400 \mathrm{~mm}$ e $2300 \mathrm{~mm}$ (figura 03 ) e apresenta os maiores indices pluviometricos no perlodo de outubro a abril enquanto que no perfodo de maio a agosto, a 


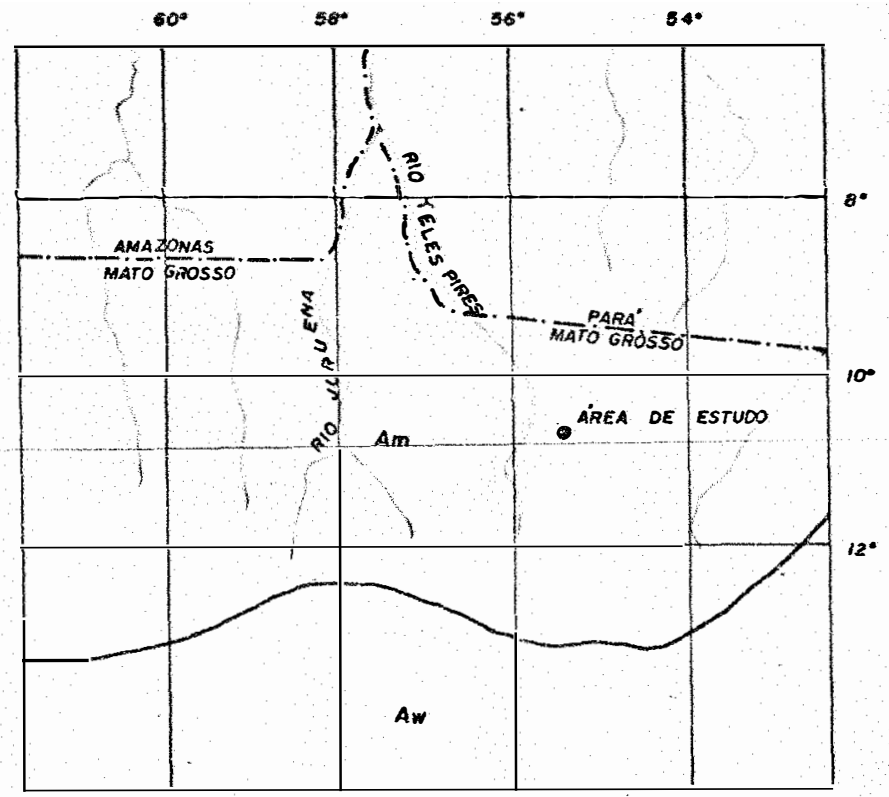

Figura os-Tipos de clima sesundo a classificacio de Koppen, Fonte: Projeto RADAMBRASIL... 1980.

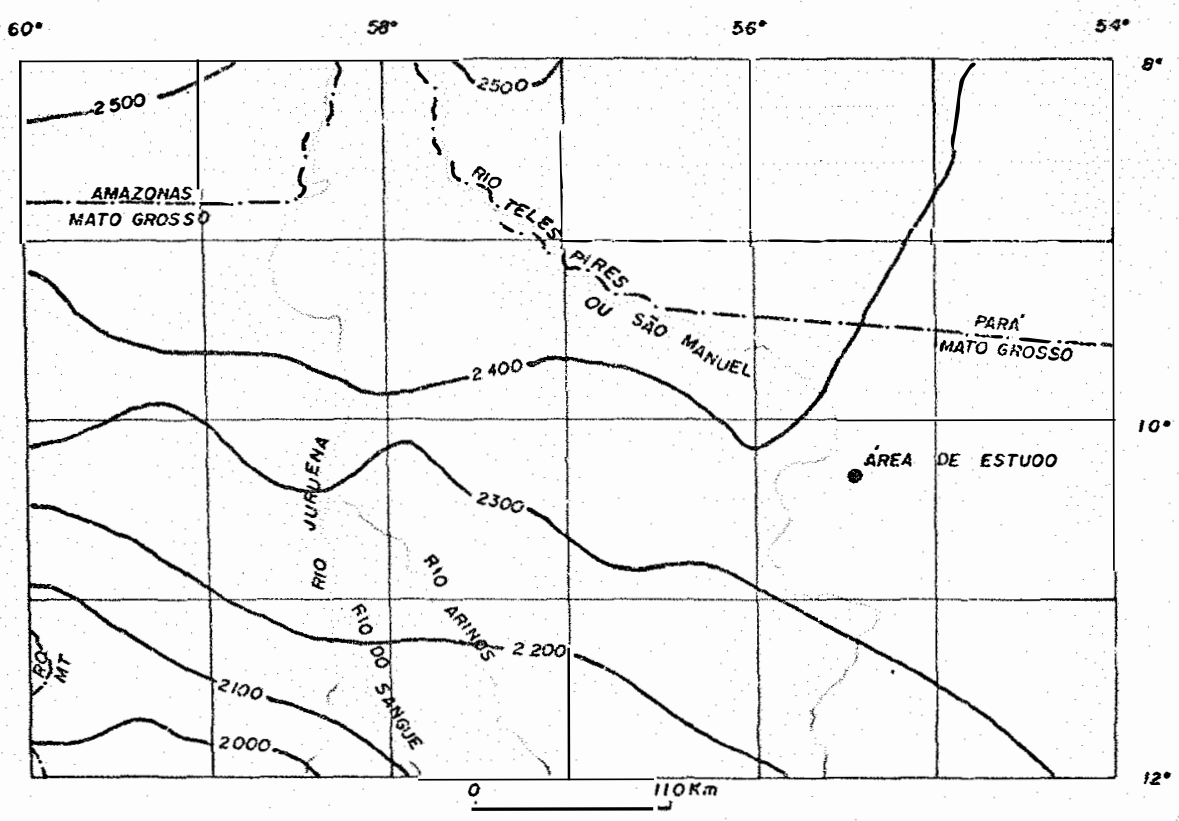

Figura 03 - Distribuicáo da precipitacáo total média anual. (mm), Fonte: Projeto RADAMBRASTL - 1980. 
pluviosidade Eastante reduzida.

Considerando a indisponibilidade de dados meteorologicos especificos da área estudada e mesmo do municipio de Terra Nova do Norte en virtude de näo possuir nenhuma estacia meteorologica ats o presente momento, foi necessario portanto, analisar dados meteorológicos coletados pelas estacies das regibes mais proximas deste municipio que säo a de Cachimbo - Mr e de Vera - Gieba Celeste - MT, para que fosse possivel realizar as extrapolacóes necessárias àrea estudada.

Assim, a partir dos dados medios nensais de precipitacáo, observa-se que na regiáo de cachimbo - MT, as chuvas iniciam-se en setembro com $139 \mathrm{~mm}$, aumentando gradat ivamente até novembro com 34 thm e diminuindo um posco en dezembro. Cresce novamente a partir de janeiro até at ingir o indice máximo no mês de marso com $373 \mathrm{~mm}$, que é o mês mais chuvoso. Na regiáo de Vera - Gleba Celeste - MT, as chuvas iniciam em outubro com $177 \mathrm{~mm}$ e aumentam gradativamente até dezembro com $383 \mathrm{~mm}$, diminuindo um pouco en janeiro. En fevereiro atinge o indice maximo com 4jom que é o mês mais chuvoso.

o balango hidrico realiaado pelo PROUETO RADAMBRASIL (1980); ( Tabelas O1 0 o e Figura 04), ut ilizando os dados meteorol6gicos coletados pelas estacöes retromencionadas, possibilita a detectäo de uma deficiencia hidrica no solo durante tres meses consecutivos, ou seja, de junto a agosto, totalizando elgmm para a regia de 

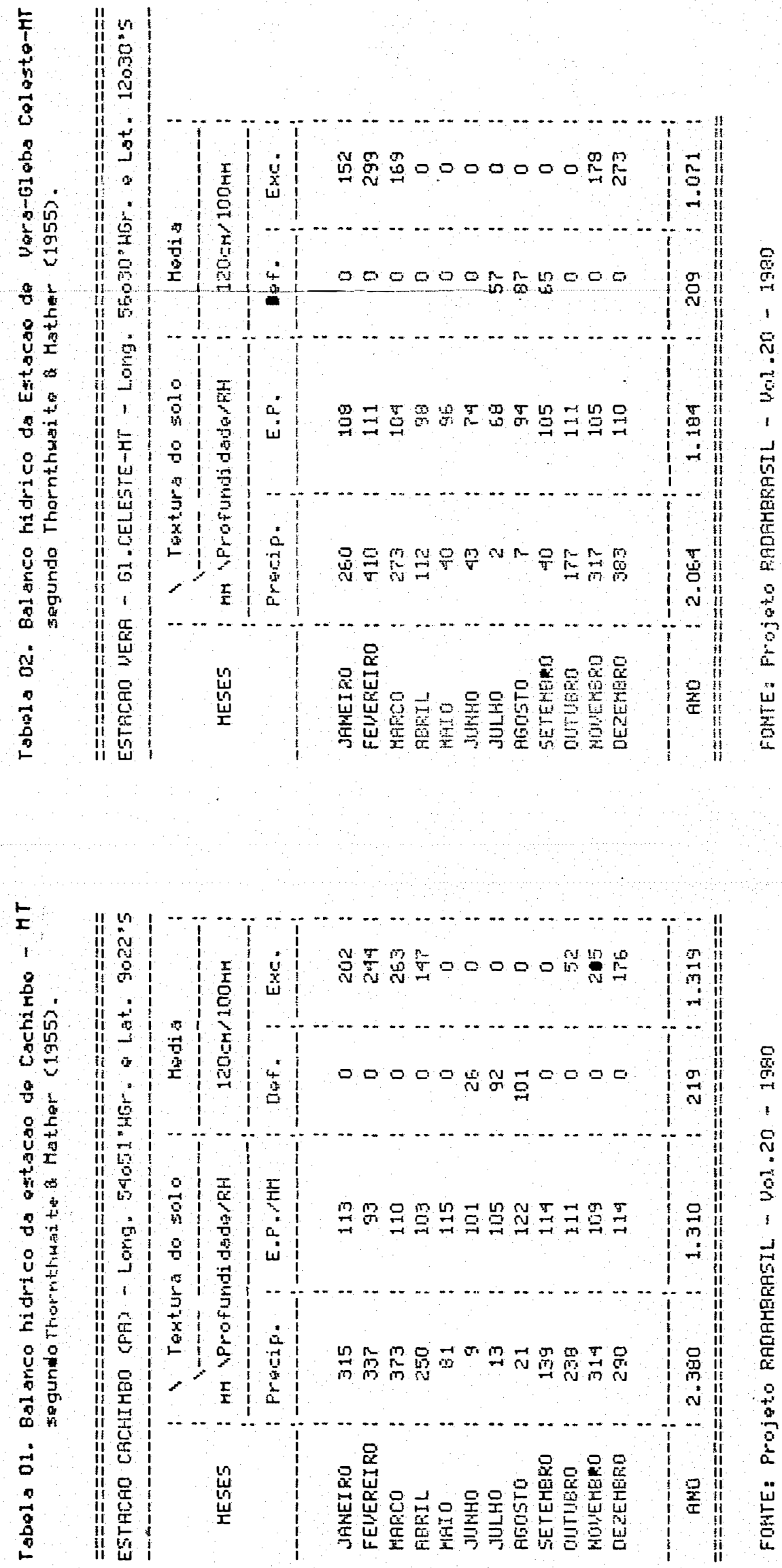

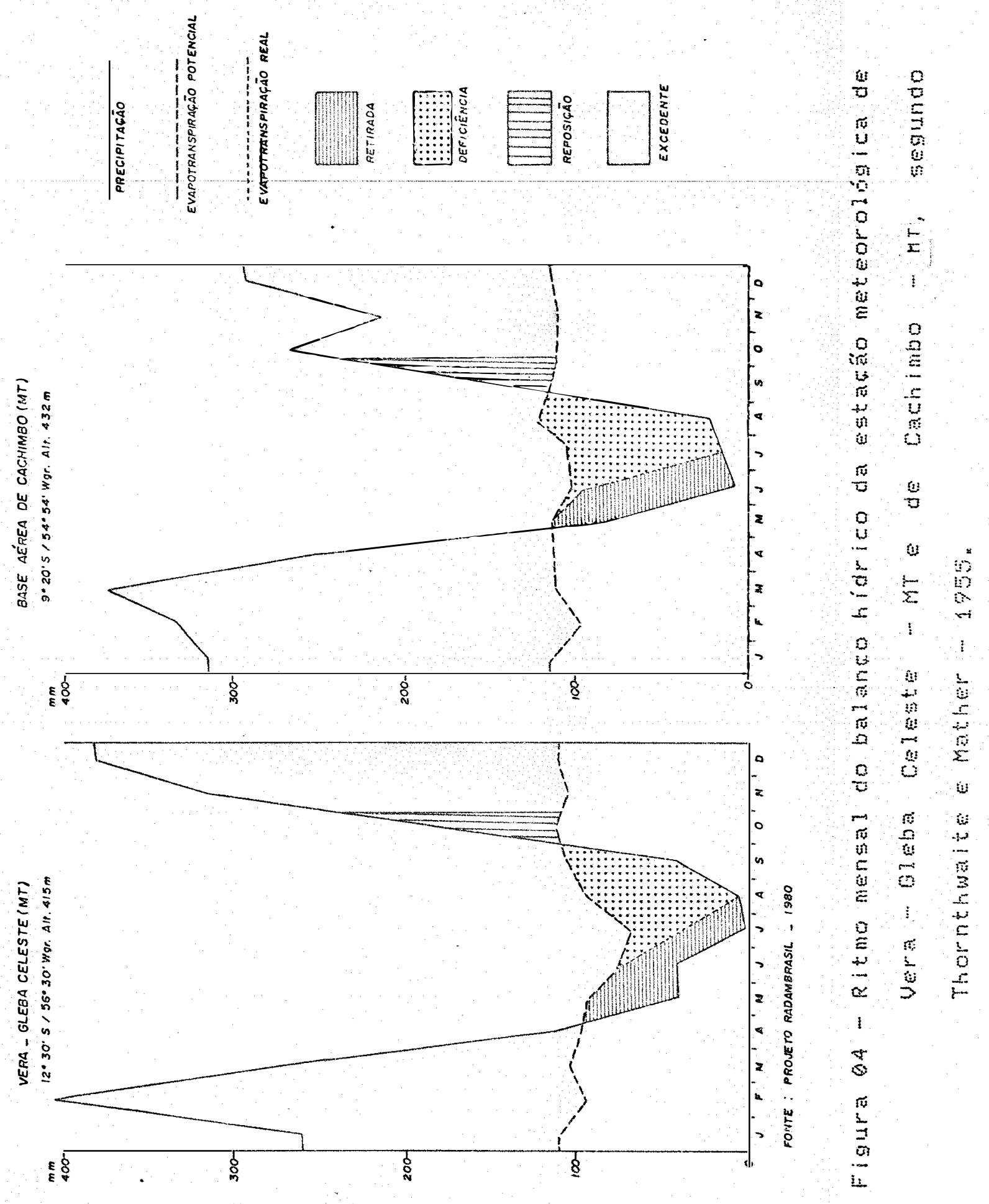
Cachimbo - MT (Figura OA e Tabela Q2) e nos meses de julho a setembro, totalizando $209 \mathrm{~mm}$ para a regiăo de Vera - Gleba Celeste - mT (Figura Q4 e Tabela Q1) e que em ambas as regiós, esta deficiencia so mas acentuada no transcorrer do mes de agosto, at ingindo solmm e $87 \mathrm{~mm}$ respectivament: Por outro lado, na regiato de Cachimbo min, o excendente hidrico que ede $13 x 9 \mathrm{~mm}$ (Tabela 02 e Figura OA) inicia no mes de outubro com $52 m m$ e aumenta gradativamente até um pico no mes de marco com $263 \mathrm{~mm}$ edectina em abril ate atingir valores nulos no perfodo de maio a setembro. la na regiäo de Vera - Gleba celeste - Mr, o excedente hidrico que $E$ de $1.071 \mathrm{~mm}$ (Tabela OS E Figura OA), se verifica somente a partir do mes de novembro com 17 gmm, consina ate margo com ib9m e a partir daf perduram valores nulos en todo o perfodo de abril a outubro.

Com relagăo à temperatura, a media anual é de 24oc (Figura Q5) e a media do mes mas frio esuperior a 1506 (PROUETO RADAMBRASTL - 1880 ).

J segundo NIMER (1979), o CI ima quente dominante na regia Norte, com temperatura que varia de $2 A$ a 2600 é consequente da sua extensa planura situada proximo ao nível do mar, e cortada de un extremo a ouro pelo paralelo do Equador. Esse mesmo autor cita ainda que, somente restritas areas do sudoeste da Regiano Norte e areas reservas da fronteira setentrional e da chapada dos parecis em Rondonia, possuem temperatura media anual inferior a 240C, devido at maior participacio de massa polar e pela alt itude bem acima da planura regional. 


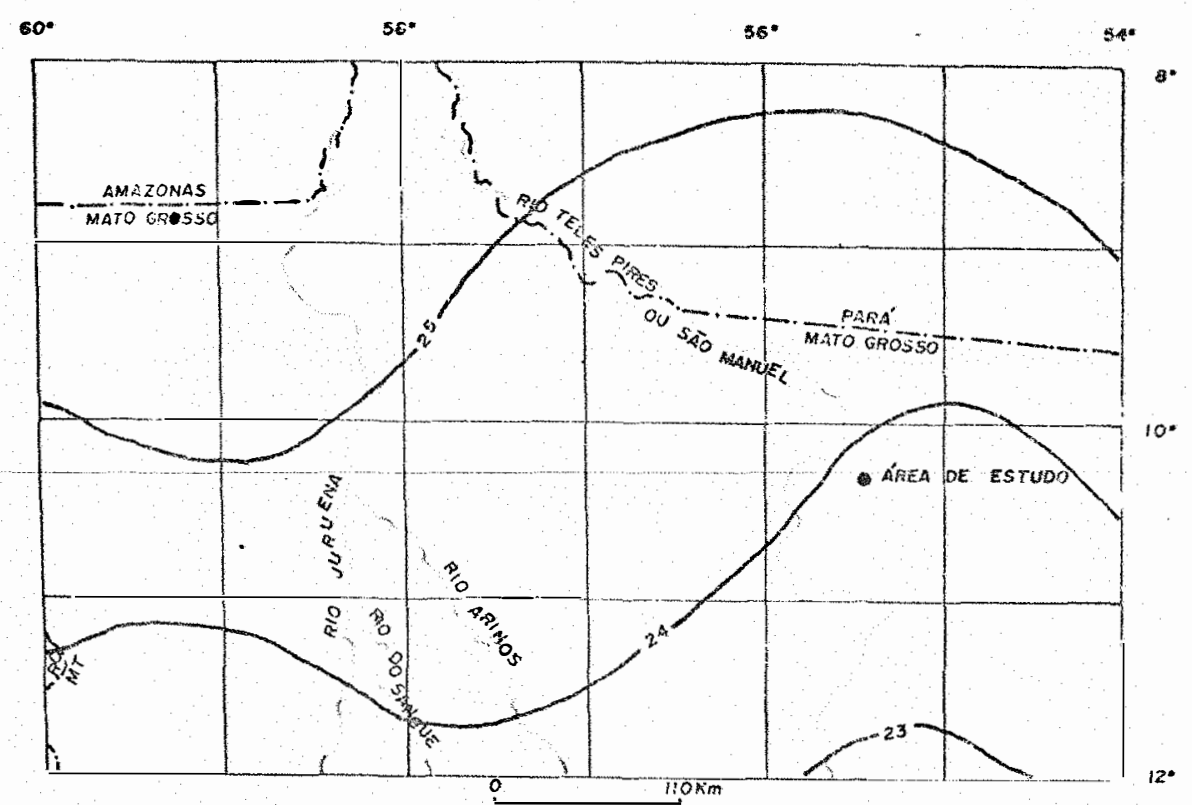

Figura os - Distribuigo espacial das temperaturas medias andats (oc)

Fonce: Projeto RADAMBASTL - 3980.

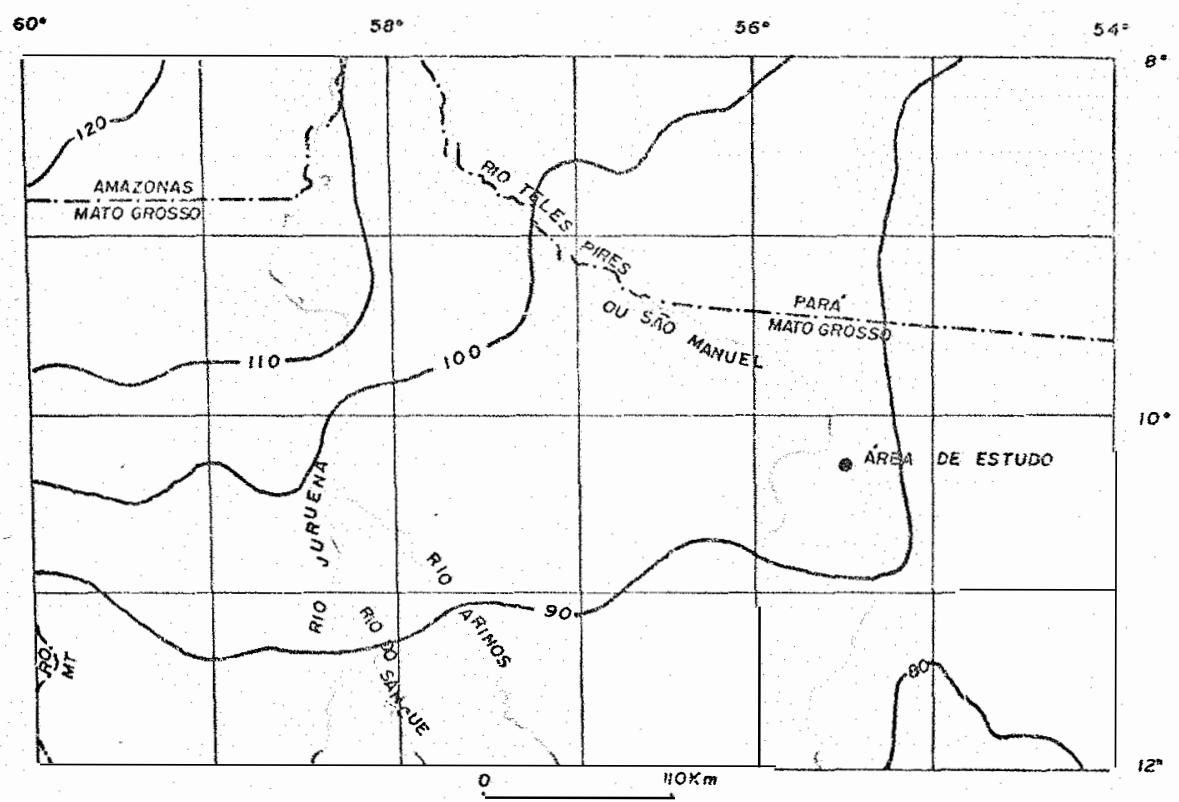

Figura 06 - Indice de unidade de Thornthwate Fonte: Projeto RADAMBRASTL -1980. 
A umidade relativa do ar na regiăo bastante elevada, pois a mesma atinge valores de ate $90 \%$ $(F i g u t a b)$

Os ventos leste predominam o ano todo, mas na estacăo chuvosa que inicia em setembro e perdura ate marso, os ventos passam a $N$ e NE com predomínio da massa de ar Equatorial Continental ena estaga do inverno, os ventos passam de SE a ESE em consequencia da entrada de ar POLAR (PROJETO RADAMBRASHL - 1980).

\subsection{3 - Uggetacăo.}

A area en roco encontrase no dominio da "Floresta Ombrofila Aberta Tropical" e compoe a unidade de mapeamento derominada "florssta submontana com cipos", segundo o mapeamento realizado pelo pROJETO RADAmBRASAL. (1.980). Ocorre preferencialmente nas depressós, mas ocufa tambén as encostas das elevacbes rochosas, prineipalmente nas cristas quartóticas e e tipicamente caracteriagda pelo envolvimento das árvores, por lianas lenbosas. como especies arboreas, destacamone algumas especies tais como: Apuleia molaris (amareläo), Basassa guianensis (tatajuba), Astronium gracilis (aroeira), Bertholletia excelsa (castanheira), talvez as unicas arvores que al apresentam una regeneragäo numerosa. As outras especies con regeneracão que al ocorrem säo a palmeiras.

Considerando a inda o mapeamento realizado PEIO PROJETO RADAMBRASIL (1980) (Figura OY) E registrada 


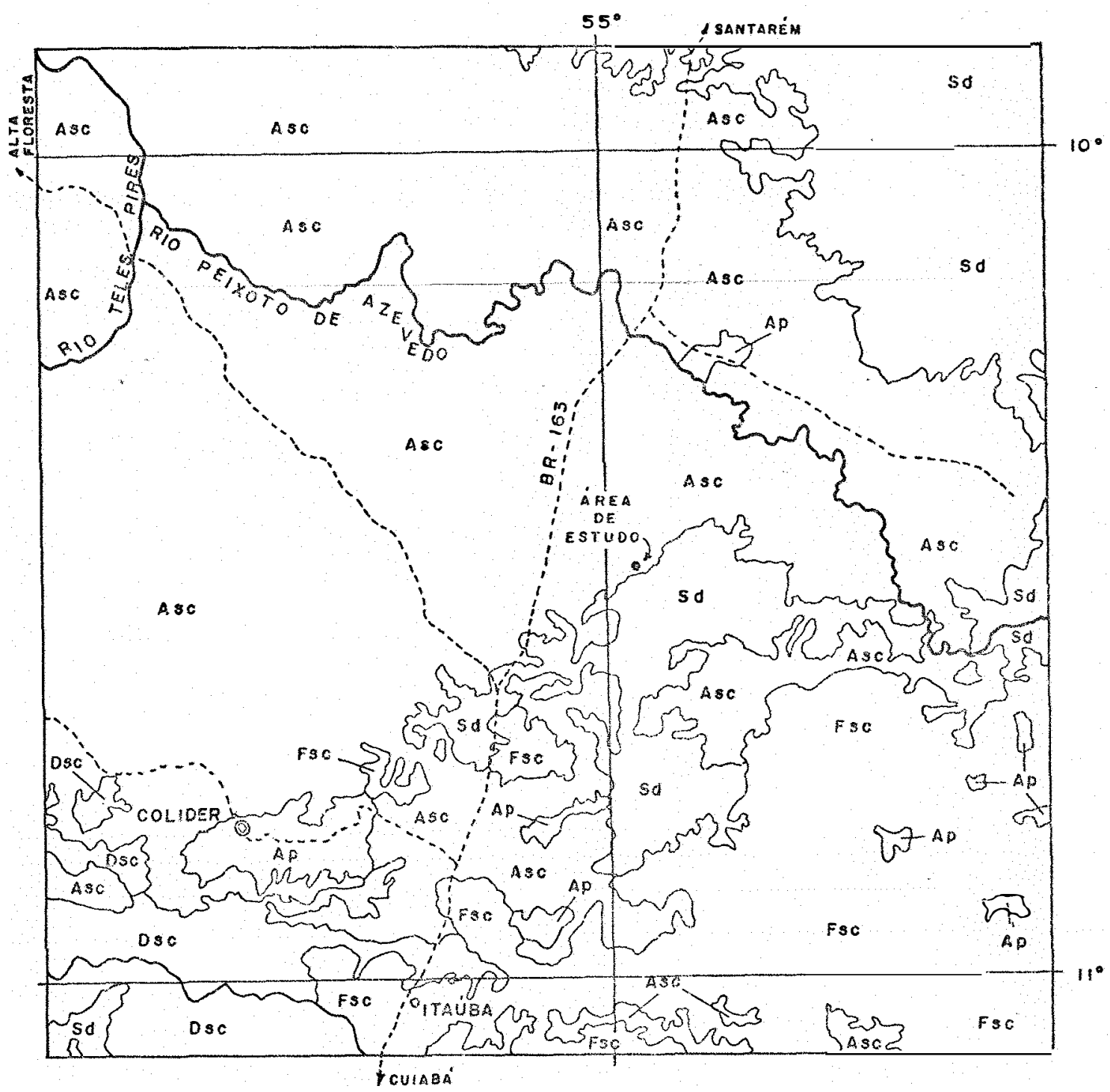

LEGENDA

ASC FLORESTA SUEMONTANA COM CIPÓS

ESCALA $=1: 1.000 .000$

So contato savana/floresta estacional

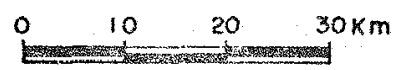

DSC FloREsta SUgMONTANA DOSSEL EMERGENTE

FSC FLORESTA SEMIDECIDUAL SUBMONTANA
DOSSEL EMERGENTE.

FONTE:-MAPA FITOGEOGRÁFICO

PROJETO RADAMBRASIL

AP AGROPECUÁRIA: PASTAGENS

1.980

Figura oy - Mapa da cobertura vegetal da regiáo estudada Fonte: Projeto RADAmBRAst - 1980. 
tambem, proxima a área estudada un dominio menor de vegetacäo denominada "areas de tensäo ecologica" "Este tipo de formacáo vegetal que ocorre nas areas de transifäo climatica (muitas vezes coincidsentes com o contato de duas formacöes geologicas diferentes aparece en falkas entre as c.lasses de formacäo que se contatam e onde se constata uma mistura de especies vegetais. Alen do fator climatico e litologico existe tamben o fator pedologico que contribui para a formacto dessas áreas de tensäo.

\subsubsection{Geologia e Petrologia.}

o embasamento rochoso da área estudada t constituida por um matico granitico de dimenswes batolitas que se expbe a poucos quilomertos da sede do municipio de Terra Nova do Norte - MT. Este macico granitico encontra-se regularmente recoberto por um manto de intemperismo. apresentando na sua superficie, um solo jovem pois apresenta ainda, quantidades apresiaveis de minerais intemperizaveis e a pouca profundidade encontrass Prequentemente a arena. Esporadicamente ocorren afloramentos en matacbes de forma e tamanho wariados.

Segundo o mapeamento realizado pelo PROJETO RADAMBRASTL (1980), este granito pertence ao grupo Uatumä e Eclassificado como Granito Teles pires (figura (8) que E constituido por granitos, granofiros, microgranitos, com tendencia alasquitica, subvulcanicas, cratogenicos, exibindo frequentemente feicäo circular; às 


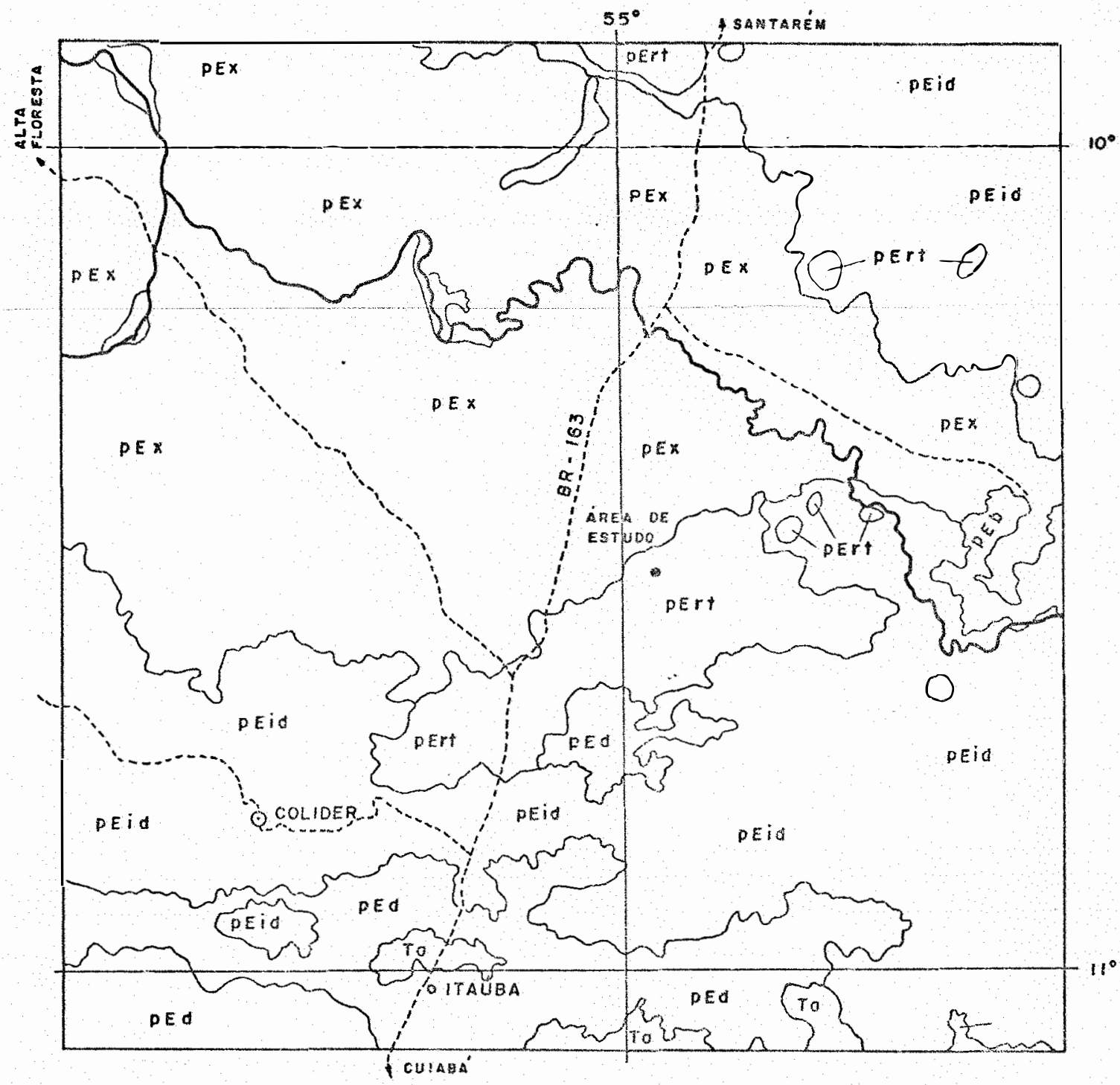

LEGENDA

PEET GRANITO TELES PIRES
DEX COMPLEXO XINGU
PEIO] FORMAGĀO IRIRI
PED FORMAGÃO DARDANELOS
PED GRUPO BENEFICIENTE
TO FORMAGÃO ARAGUAIA

ESCALA: $1: 1000000$

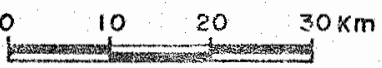

FONTE: PROJETO RADAMBRASIL

Figura os - Mapa geologico da regian estudada

Fonte: Projeto RADAMERASIL - 1900. 
veases com textura rapakivi e exibe manifestacăo magmácica intrusiva, correspondente ao vudanismo subseguente da consolidacă cratonica.

Essas roctras intrusivas estấ expostas em cortes de estrada ao longo da rodovia liz-163 coniabá Gantarén) entre os narcos $629 \mathrm{~km}$ e $64 \mathrm{~km}$ e entre o marco $730 \mathrm{~km}$ e o rio Braco sud, marco 741 na borda sul da serra do Cachimbo (PROUETO RADAMBRASIL -.. 1980). Ocorrem sambém no leito do riotelespires, associado as efusivas da Pormacáo Iriri no trecho entre as desembocaduras dos rios Apiacá e paranaita, sendo que na cachoeira das seta obedas, no rio reles pires, estes litotipos estäo melhor representados (PROJETO RADAMBRAST - T.8\%) "

Acredita-se que a exansondo desse gramito subvaloanico ultrapasse em muto a frea del imitada pato mapeamento realizado, porque as veriticabes de campo revezaran, segundo PROJETO RABABBRASIL. 1980 , a axisteneia de dezenas de corpos aranticos subulosnioos sem grande destame nos mosaicos de radar ou fotos infravermelho. tendo em vista que a eficiencia da aro erosiva diffoula frequentemente a visual izacăo das estruturas quase sempre circulares caracteristicos desses corpos intrusivos. atraves das imagens retromencionadas.

As analises radiometricas pelo metodo Rb/Sr, de varias amostras selecionadas de granitos intrusivos subvulcanicos Teles pires, revelam a idade en torno dE 1. EAB + 2E M.A. (PROJETO RADAMBRAGIL - 198O).

Atraves das andises petrograficas en 
secóses delgadas de varias amostras do granito reles pires, foi possfvel visualizar as sequintes varbacoses composicionais e texturais segundo o PROJETO RADAMBRASIL $(1980):$

$$
\text { I - Granito: apresenta textura }
$$

hipidiombrica composto de ortociasio pertitiso, martao, plagioclasio, biotita, calcita, titanita e opacos.

- o ortoclasio perticico nas formas subedrica e anedrica, micropraturado, as vezes, com

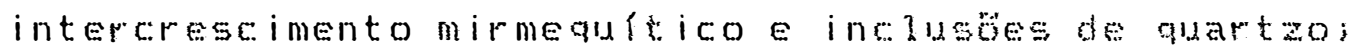

$$
\text { - o quartao de formas hipidiombrtion e }
$$

xenomitica, microfraturado, extinato ondulante, as veses corroldo, ocorre tanto em orlstais bem desenvoluidos como intercrescido rom feldspato;

- o plagioclasio em prismas suberrieos, microfraturados, com macla de albita e alterado a sericita, argilominerais e epidoto:

- a biotita em placas de ate zmm, pleocroismo marrom, transformada em clorita e opacos;

- principais acessorios sáo representados por titanita, fluorita e epldoto.

Ix - Oranito porfiro e microgranito: de textura porfirtica e microcristalina, compoen-se essencialmente de guartzo, ortociásio pertítico e plagioclasio; minerais acessorios: titanita, fluorita, zircaso, apatita e epfoto; minerais secundarios: colorita, Epidoto, argilominerais, sericita e carbonaco; 
- o ortoclasio pertitico de formas

enedrica a ansdrica, intercrescimento formando filmes e cunhas, reacato com quartzo nas bordas, contém relictos de plagioclásio, alterawse parcialmente a sericita e argilom mineraisi

- o quarta: en fenocristais e na matriz, os fenocristais com formas anedrias e subedricas, bordas corroidas, extingro ondulante;

- o plagioclásio: en prismas, formas

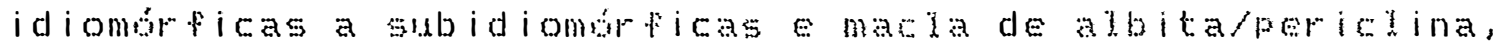
inclusóses de quarta, alterado predominantemente a aroilominerais, sericita e em menor auntidade a epidoto, alguns cristais de apatita inclusos;

- a microclina: as vezes pertitica, ocorre como mineral secundario, macla de albitalperielina, alterada geralmente a argilowminerais e raramente a sericita, apresenta relictos de plagioclasio e inclusaco de quartao;

- a biotita: parciaimente cloritianat com placas bem desenvolvidas, pleocoismo marromescuro, inclusöes de epídoto, aircäo efacos;

- a hornblenda: alterada parcialmente a clorita e opacos, prismas bem formados, inclusio de quartzo, zircát apat ita e opacos; juntamente com a biotita constituem os principais máficos dessas roctas;

- a titanita 6 um dos principais acessorios com formas xenomorficase idiombrticas, alterado a minerais opacos; 
-... a apatita: ocorre como prismas alongados inclusos nos feldspatos, nos maticos e na matria, jumamente com o quartaco feddspato;

o... carbonato (calcita) e pluorita: ocorren com pequenos retstais formando agregados com os máticose opacos.

III. Granofiros egrotos graficos: a composigato mas comam é a granftica, sendo composta Essencialmente por quartas a boclasio, este muitas veres pertitica, rom plagioclasio subordindo; quataro e

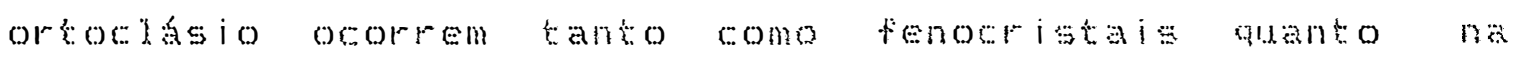

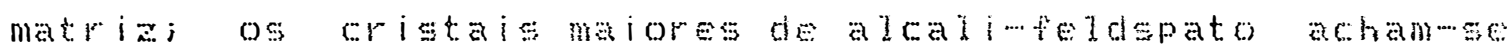
com tregueneia reaborvidos nas bordas pela matria e esto sempre areitiandos com ou sem impregnabo de oxido de fierro:

- os plagiondisios transtormamse en SEricita e: eploto; o plagiocdasio fom mais abundante que o ortociasio, formando a gramde maioria dos fenocristaise o quartao restringense dे matria;

- os máricos sä́o raros, resumindo-se a lamelas esparsas de biotita, parcial ou totalmente wor itizados, e alguns acessorios (ebloto, esteno, opacos exircäor;

$$
\text { - os grangiros apresentam efeitos }
$$

cataclasticos denunoiados pelo encurvamento das lamelas de geminacăo dos feldspatos, microfraturamento e extincăo ondulante do quartzo. 


\section{$3.1 .5-$ Geomorfologia.}

A area estudada corresponde a uma superficie intrusiva disposta na pepressäo Interplanaltica da Amánia rieridiona" e muito erbomo à extensa unidade geomorfologica que ó a do "planalto dos parecis" cFigura Q9). Tal superficie é caracterianda por formas agucadas ou convexas, as qua is aresentan desnivel consideravel en relacáo ao piso da depressáo.

Sua litologia corresponde ao granito intrusivo do précambriano superior, denominado de Granito Teles pires, o qual foi or 9 inado em funcäo do vuleanismo

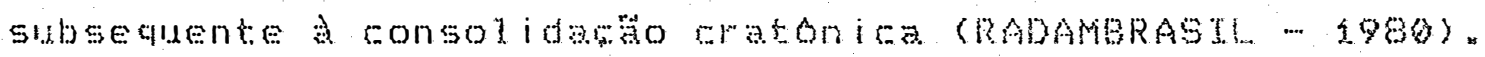

Ao norte desea superficie, obervases a contindidade da "Depressio rnterplansteica da mazonia Meridional" ate se confinar entre as serras e Chapadas do Cachimbo e a conevro com a "Serra formosa" CRabamerastl.1.980). De uma maneira mais ampla e continua, observa se que essa depressio se estende na direfaro oesteworoste, bem alem do rio Juruena. Ainda, segundo RAbribraste (1980), essa depressä́o consiste numa extensa superflcie rebaixad, dissecada em formas dominantemente convexas, com als imetria que varian de zon a 300 metros e drenagem organizada segindo padräo dendritico abrange quase totalmente litologias prewcambrianas do "Complexo xingá", com excessäo da parte norte, onde se encontra rochas sedinentares tamben prewcambrianas do "orupo Beneficiente" " os solos que predominam säo os podzolicos vermelhos distroficos e 


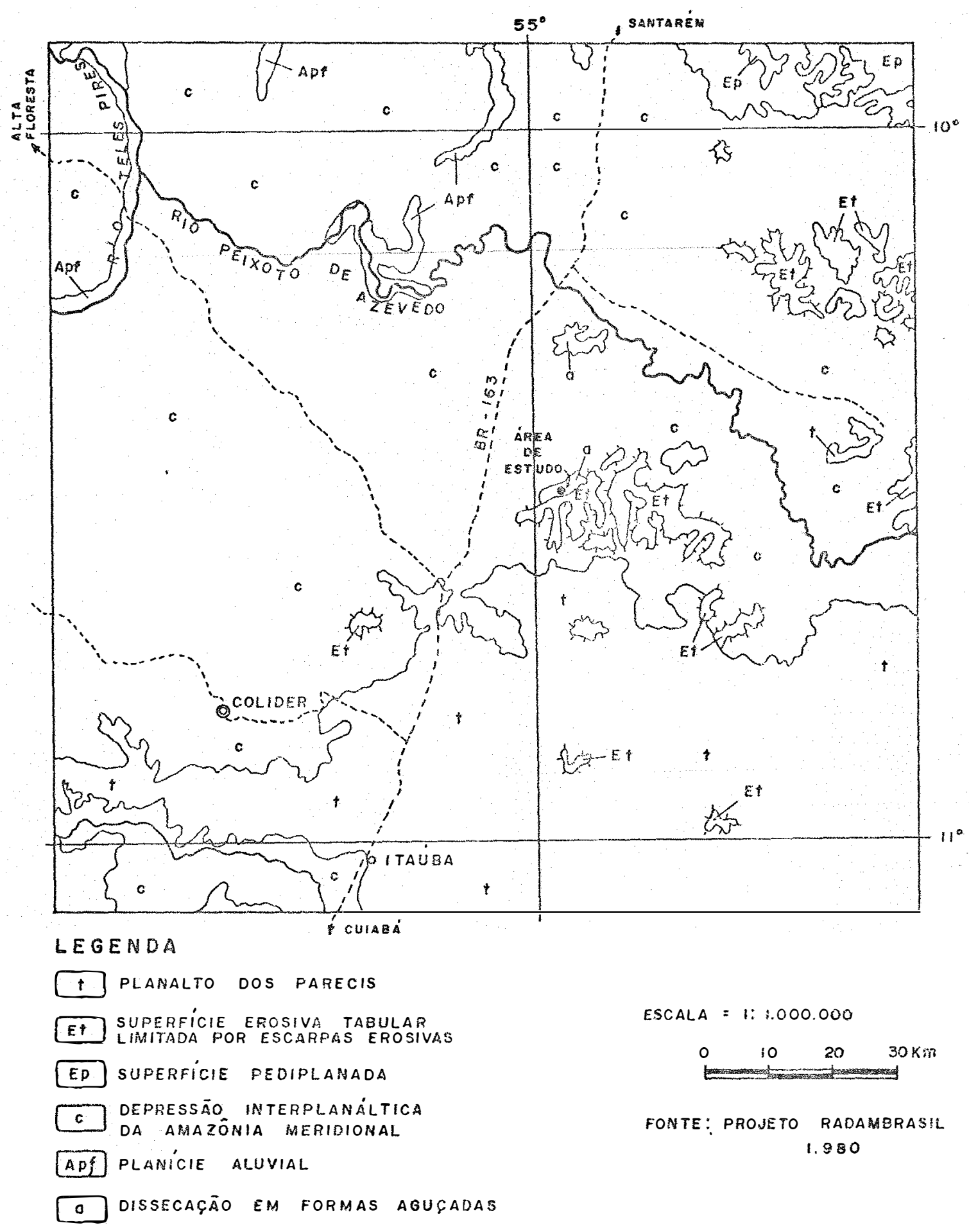

Figura os - Mapa geomortolsgito da mogino estudada Fonte: Projeto RADAMBRAGIL - 1990. 
Latossolos Vermelho-fmarelos.

Ja ao sul da frea estudada, encontra-se

uma outra extensa unidade geomorfologica denominada de "Planalto dos parecis" que e relativamente homsonene, com altimerias que variam de $40 \Leftrightarrow$ a 330 metros de leste para oeste. Essa peguena diferenciagúo no grad de intensidade da dissecacäo, corresponde a uma diversificacia litologica que indug a divisäo do planalto, em duas secées, sendo que o Rio teles pires funciona como un eixo divisor (RADAMBRASLL - 1930$)$, tendo a leste, rochas vulcanicas da formacto Irirí e a oeste, os sedimentos précambrianos da formacia bardanelos.

$$
3.1 .6-50105 .
$$

Säo tres os grandes grupos de 50 los que ocorrem na regiäo de Terra Nove do Norte, segundo o mapeamento de solos real izado pelo pROJETO RADAMBRASIL (1980): 1) - Podzblico VermelhowAmarelo distrofico; 2) Latossolo VermelhomAmarelo dietrofico; 3r - Solos Concrecionarios distroficos (Figura $f(\theta)$. Säo apresentadas a seguir, um resumo das suas principais caracteristicas:

1) Podablico Vermelhomamarelo distrofico apresenta horiante $B$ textural, näo hidrombrfico, com atividade de argila e saturafio de bases baxas. moderadamente a bem drenados, profundidade varikved.

Horizonte A-com 10 e $40 \mathrm{~cm}$, cores nas matizes 1OYR E7, GYR (bruno), textura francomarenosa a 


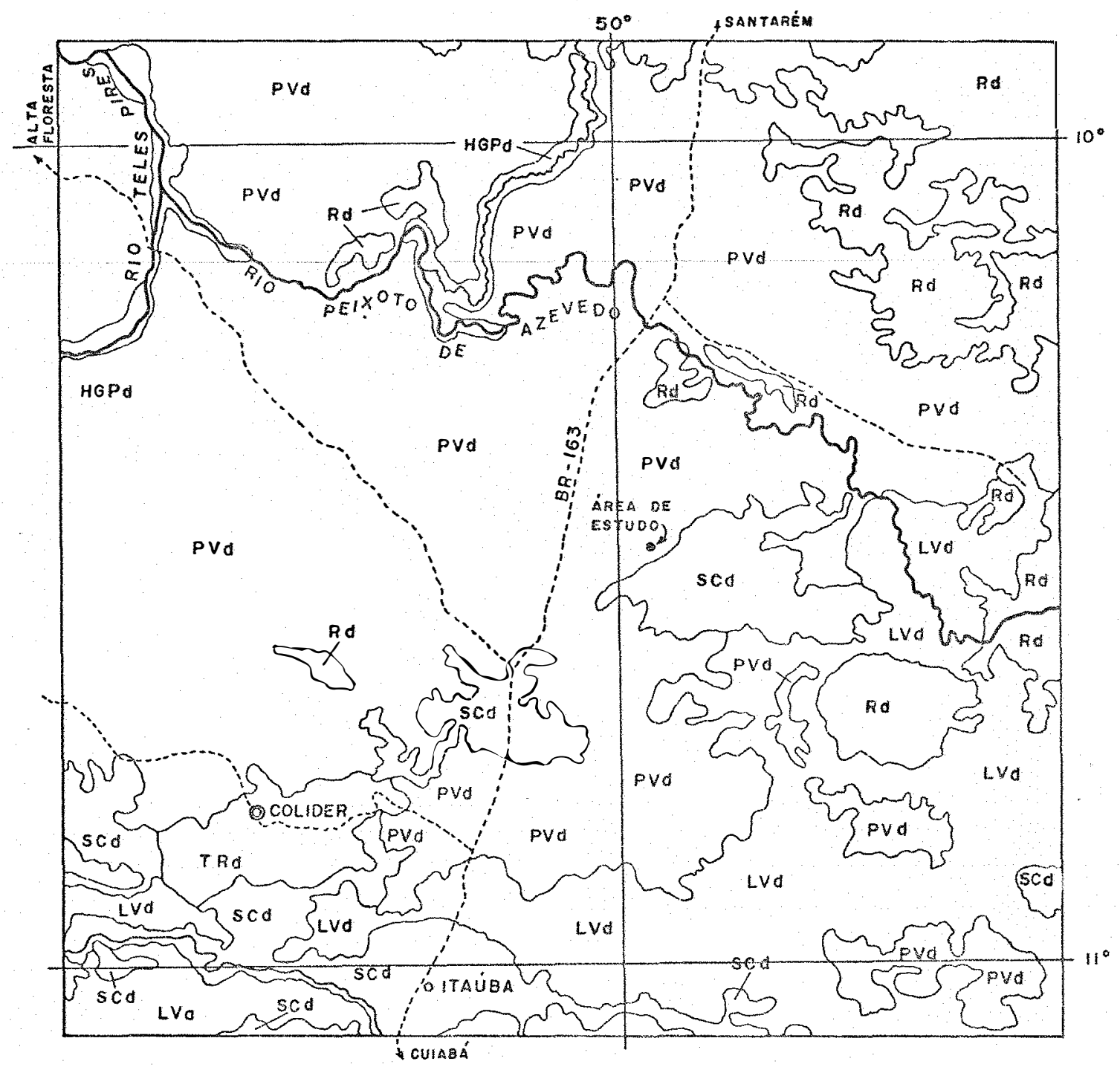

\section{LEGENDA}

PVd PODZÓLICO VERMELHO-AMARELO DISTRÓFICO

SCD SOLOS CONCRECIONÁRIOS DISTRÓFICOS

Rd SOLOS LITÓLICOS DISTRÓFICOS

LVO LATOSSOLO VERMELHO - AMARELO ÁLICO

ESCALA $=1: 1.000 .000$

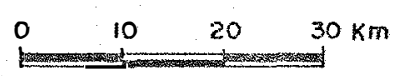

FONTE: PROJETO RADAMBRASIL 1980

LVd LATOSSOLO VERMELHO - AMARELO DISTRÓfico

HGPO GLEI POUCO HUMMIDO DISTRÓFICO

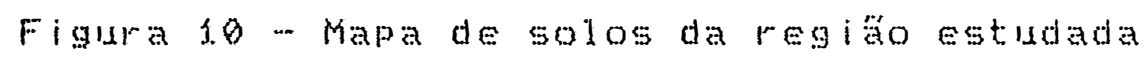

Fonte: Projeto RADAMBRAGIL - 1980. 
francomargilo-arenosa, estrutura com fraco desenvolvimento, consistência friável a muito friável, näo plástico a plástico e näo pegajoso a pegajoso, transigáo gradual.

Horizonte B -. profundidade variácel, cores geralmente brunowavermelnadas (GYR e $7, G Y R$ ), as vezes, vermelha a vermelha-escura $(3, G Y R$ e $10 R)$, textura franco argilo-arenosa a argila pesada e muito variavel em profundidade, estrutura em blocos subangulares, pequenose medios, muto fraca, consistencia friável, plastico e pegajoso, alto grau de floculacäo ( >95\%), baka relacto siltedargila.

Säo solos com teor de carbono< $2 \%$, A?

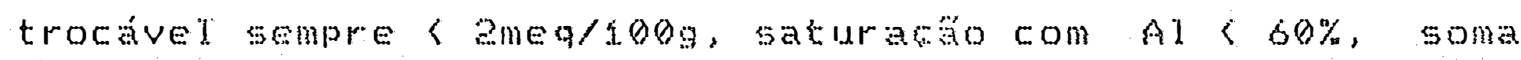
de bases muto baixa, geralmente< que imegroos, saturaca de bases sempre< $50 \%$

ocorrem desde relevo plano até forte ondulado, associados mais frequentemente as rochas do complexo xingu esáo classificados pela "Soil Taxonomy" como orthoxic Tropudult, orthoxic e Rodic palehumult, Tupie E Petroferric Paleudult e orthoxic Rhodudult.

Esse grande grupo, incorpora nas suas unidades de mapeamento, unidades menores de latossolo Vermelhowamarelo distrofico, l.atossolo Vermelhomescuro distrofico, solos concrecionarios distraficos e solos Litolicos distroficos.

a) Latossolo Vermelho-Amarelo distrofico: apresenta horigonte B latossblico, näo hidrombico. 
assemelhando-se aos Latossolos vermelhowescuro em suas caracterlsticas morfológicas, fisicase quimicas, sendo no entanto de coloracäo menos avermelhada en funcä́o dos menores teores de bxidos de Fe.

Horizonte A com $35 \mathrm{~cm}$ de profundidade média, subdividida em At e A3, epipedon borico, A moderado, cores GYR e 7, GYR (brunowavermelhada, vermelhowamaredada e bruno forted, tentura francomarenosa para os de textura media e nos argilosos eargila, estrutura granular pequena e fraca, consistencia geralmente friavel, ligeiramente plasticoe ligeiramente pegajoso.

Horizonte B com cores $5 Y R$ E $2,5 Y R$ (vermelhomamarelada, vermelha e amarelo-avermelhada), predominando textura franco-argilowarenosa e francowarenosa para os de textura media e argila a aroila pesada para os argilosos, estrutura en bloco macico mido poroso, consistencia mito friavel a firme, ligeiramente plaseico a muito plastico, ligeiramente pegajoso a mito pegajoso, transicöes difusas entre subhorizontes.

A saturacáo de bases é sempre inferior a $50 \%$, saturaxio com Al variando de 0 a $80 \%$, soma de bases é sempre inferior a cemea/100, apresenta baixa relacáo textural, evidenciando uma distribuica uniforme das argilas ao longo do perfil e quase totalmente floculadas, a CTC é mais elevada na parte superficial; a baixa saturafáo de bases e soma de bases trocaveis, evidencia solos intensamente meteorizados.

No sistema americano de classificacăo 
"Soil Taxonoms", os latossolos do plato superior do Planalto dos parecis se correlacionam aos typic e Haplic Acrusthom enquanto que os das dreas disseradas em superficies mais recentes se correlacionam aos ultic e Quartaipsammentic. Haplusthox.

Esse grande gripo de solo incorpora nas suas unidades de mapeamento, pequenas ocorrencias de podablico Vermelhowamatelo distrofico, solos concrecionarios distroticos.

3) Solos Conerecionarios distróticos -..

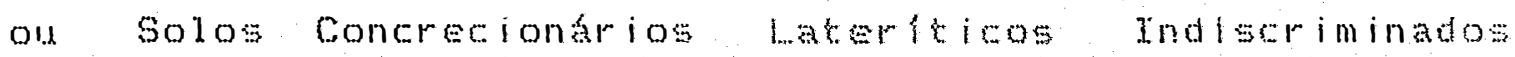
distroficos, sao raros, com dominancia de frabes grosseiras, principalmente cascalbo, este ferrusinoso fa quase totalmente arredondado; pressupobse que aste solo seja produto residual de deagregato das baneadas laterticas que existiam na regiano; a cerosidade na face das concrecoses e o gradiente textural em alouns casos, condizem com o que se denomina hor zonte B textural, juntamente com howizonte b latossblico mais commente a - ancontrada; a semuencia de seus horizontes e Acn. Ben, Cen OLIT.

Hor izonte Acn polso protundo, menos aue 20om, cores brunada, vermelhomamelada se vermelha, textura argilosa, estrutura näo discernivel.

Parte interior do solo: con expessura muto variavel, com cores bmunowavermelhada e vermelha, com caracter sticas físicas semelhantes as do horizonte 
Acn.

Säo mito ácidos, pHem HeO prowimo a 4 , saturacáo de Al trocável às vezes alta na superfície, valor "S" inferior a $15 \%$, teor de bido de Fe livre en torno de g a 8\%" de acordo com o "Soil Taxonomy" se correlacionam aos Withic oxic Ustorthent e petoferric-paleustut.

\section{2 - Material.}

Para atingir os objetivos desta pesquisa, foram coletados no transcorrer do trabalho de campo, amostras dos seguintes materiais:

. I t teira

.5010 -- (deformado e indepormado)

- arena - (deformada e indeformada)

.rocha

- Agua da fonte

3.3 - Métodos de campo.

\subsection{1 - Coleta da liteira.}

A coleta das amostras da liteira foi

realizada com tres areas de t metro quadrado, ao longo da topossequencia, objetivando a sua quantificaca atraves de suas pesagens. As amostras da liteira foram coletadas separadamente en duas fracies, sendo gue a primeira tracăo consta defolhas, galhos e cascas de vegetacăo ainda năo decompostos e a segunda fracăo é composta por residuos vegetais já decompostos e näo identificáveis. 


\subsection{2 - Coleta de solo e arena.}

As amostras de solos foram coletadas nas Paredes de três trincheiras abertas ao longo da topossequência. os solos foram caracteriagdos pelas siglas NA1, NA2 E NAS no sentido descendente da encosta CFigura 14) "As amostras das arenas foram coletadas separadamente, mas a exemplo das amostras de solos, foram todos submetidos as mesmas análises fisicamimieaminerabóna. As amostras, tanto do solo como das arenas, consigtiman de:

a) amostras indeformadas: destinadas

andises da densidade aparente e para o estudo micromortologico apss impregnabio com resina e contectóno das secoes delgadas. Foram todas coletadas en carintas de plástico, etiquetadas e devidamente embaladas para o transporte at o laboratório;

b) amostras deformadas: destinadas as análises fisicamímicamineralógica, como também, para serem submetidas as prensagens, para a extracóo da solucáo do 5010 do perfil de alterafón todas essas amostras foram lacradas e identificadas 1090 apos a coleta, para a manutenc:äo da umidade atual de campo e assim possibilitar a Extrazio da sua soluc

\subsection{3 - Coleta das rochas.}

No transcorer da abertura dos perfis, foram amostrados aleatoriamente blocos de rochas, desde 
as camadas de superficie ate a base da trincheira. As amostras foram identificadas e a profundidade de seus respectivos sitios tamben foi anotada. Foram coletadas tambem amostras de rocha intacta pertencentes aos afloramentos granticos localizados na periferia dos perfis.

$$
3.3 .4 \text { - Coleta da água da fonte. }
$$

Objetivando identificar e quantificar os componentes minerais presentes na agua de uma fonte deste macito grantrico, foram coletadas amostras da agua de uma fonte localizada no sopé da encossa e discante aprowimadamente 500 metros das toposseguencias dos perfis estudados.

3.4 - Metodos de laboratório.

3.4 .1 - Extracăo da soluçato do 5010.

A extraço da soluctón do solo das amostras desolo, como tamben das arenas, foi realiano conforme procedimento descrito por HIGA (1907) e utilizando un cilindro de compressáo especialmente fabricado para esta pesquisa (figura 11). A forga de compressä́o é aplicada através de uma prensa hidrúlica comum.

En funcä́o das dimensöes do cilindro de compressäo e da capacidade maxima de prensa utilizada, fol empregada uma pressäo que pode ser assim demonstrada matemat icamente: 
(2)

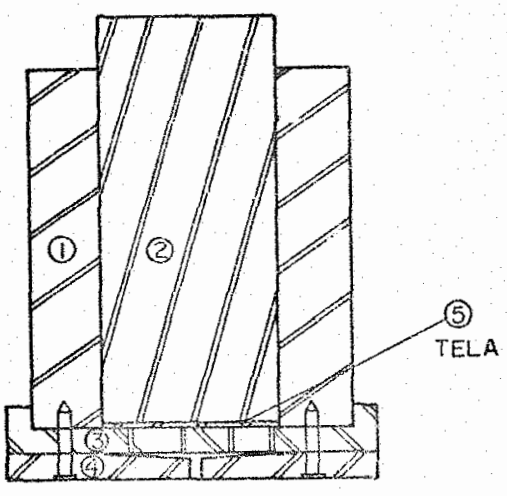

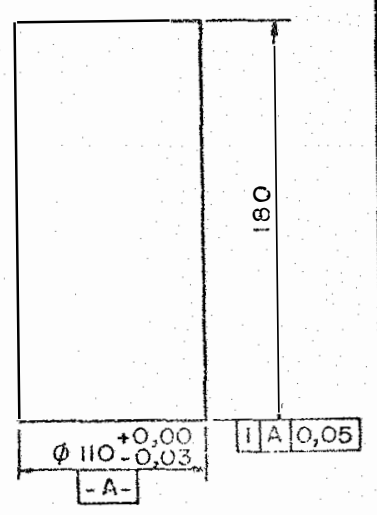

(4)
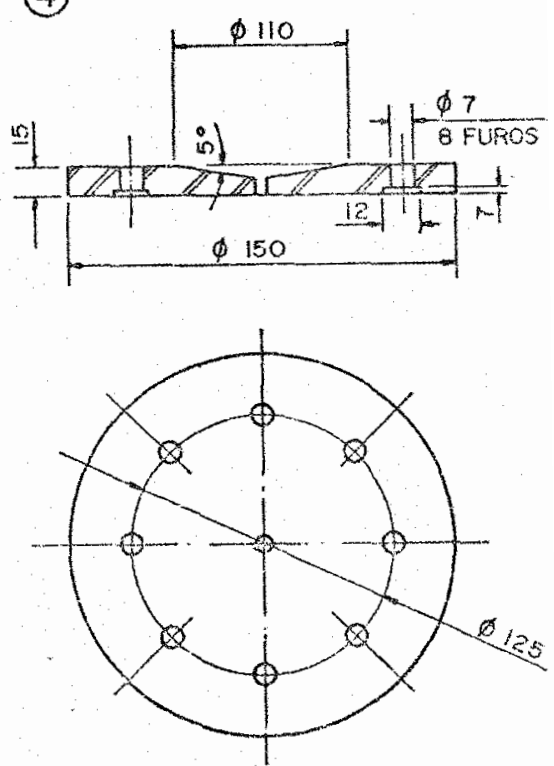

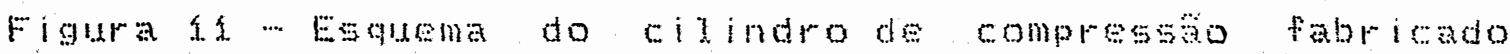
para a extracáa da solucăo do solon 


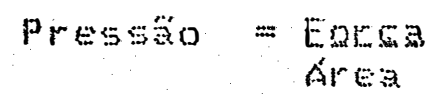

A área (S) interna do cilindro de compressáo $e^{2} \quad g=T R^{2} ;$ sendo $R$ o raio do cilindro. que é igual a s, sem; tenos poptonto:

$$
\begin{aligned}
& s=3,14 \times(5,5 \mathrm{~cm})^{2} \\
& 5=94,955 \mathrm{~cm}
\end{aligned}
$$

sendo a for $a$ (F) maxima empregada igual

a $15000 \mathrm{KgF}, \operatorname{temos}:$

$$
\begin{aligned}
& \text { Preseno = } \\
& 94,935 \mathrm{~cm} ?
\end{aligned}
$$

$$
\text { Pressa }=197,92 \mathrm{KgF/cm}
$$

Portanto a pressa móna aplicada no processo da sxtrazo da solucáno de intemperismo das amostras de 5010 e arena foi de $157,92 \mathrm{kglam} 2 \mathrm{a}$ aplicąäo desta pressá roi realizada gradativamente, utilizando una fora de 3 nobo $\mathrm{Kgl}$ de cada veze e em intervalo de tempo de 30 minutos.

Segundo OS autorES KRYUKOU (19A7), SHILOVA \& KOROVOINA (196e), KaURTHEV et ali D'YAKONOUA (1964), todos citados por BONNEAU \& SOUCHTER (1979), as pressos necessarias para extrair a maior parte das águas capilares do solo sáo da orden de 500 a 18 a Kgf/cm. Deve se ressaltar portanto, que a pressäo máxima de 1.57, 92 Kaf/cm, aplicada no presente método, possibilitol a excracádo da maior parte das águas retidas nos poros capilares do solo em questäo. 
A solucáo que escoa da amostra prensada é recolhida na base coletora do cilindro com o ausilio de uma seringa. A solucäo assim extraida é submetida a um processo de purificagáo antes de ser analisada quimicamente. Este processo de purificacán, consistiu de uma centrifugatio branda, ou seja, de 7 go RpM durante 3 minutos, para a eliminacio de partioulas grosseiras que săo incorporadas a solugäo do solo na fase da sua extracăo.

Para fins de padronionaco e correlasao dos resultados analiticos, utilizoume a quantidate de $1 \mathrm{Kade}$ solo ou arena em cada extraca. Foi necessório portanto, realizar em média. 3 extracbes para cada amostra de solo ou arena.

$$
\text { 3.4.2 - Análises fisicas do colo e da arena. }
$$

- Unidade atual -... A umidide abual foi determinada, utilizando amostras desolo se de arena con estrutura deformada. A amostra foi pesada e transperida para a estuta a 1.0oc por um perfodo de $2 A$ horas ou ate se obter um peso constante. Após este procedimento, a amostra foi colocada numa camara dessecadora e em seguida foi pesada. Assim a umidade foi calculada segundo a expressäo: $\%$ umidade $=100$ (peso da amostra fomida peso da amostra seca a 1100c)/peso da amostra seca a 11800.

- Analise granulometrica o. Inicialmente procedeu-se a separacăo da fracăo maior que emm de diâmetro de outra fracäo menor que emm (terra fina) e determinou-se - percentual de cada fracăo. A andise granulometrica foi 
realizada utilizando a fracäo terra fina, destruindo inicialmente a materia organica com a adica de Hoose posteriormente a adicato do hexametafosfato de sodio como agente dispersante, seguida pela agitacäo en garrafas de sthoman colocadas no agitador vertical, por un perfodo de 16 horas ininterruptas. Os procedimentos seguintes foram conduzidos segundo o método da pipeta, descrito no "manual de métodos de analise de solo" da EMBRAPA (1979).

- Argila dispersa em faua - $\mathrm{Na}$ determinacato da argila dispersa em agua, utilizoume unicamente agua destilada como meio de dispersón. Para a amostragem adotod- se o mesmo metodo da pipeta utiliaado na and 1 ise grandometrica.

- Grau de floculagâo - o grau de floculacto foi calculado em funcua das percentagens de argila total e argila dispersa em agua, utilizando a seguinte expressäo (UETTORI -.. 1969):

Cras de floculacăo = Cargila total argila dispersada em agda)/argila total.

- Densidade real - A densidade real toi determinada através do "método do picnómetro com água destilada, utilizando s gramas de "terra fina seca ao ar" a aplicacáo de vácuo durante 24 horas para a remogäo do ar da amostra. 0s procedimentos seguintes foram determinar os valores de: ( BLAKE, 1965):

$$
\begin{aligned}
& P=P E S 0 \text { do picnometro + água e } \\
& P 1=P E s 0 \text { do picnometro + água + solo. }
\end{aligned}
$$


A densidade real foi obtida atraves da

seguinte formula:

$$
\begin{aligned}
& \text { Dr }=\frac{(\bar{b}+5)-p i}{\text { Densidade aparente }-A \text { densidade }} \\
& \text { D... }
\end{aligned}
$$
aparente foi determinada atraves do metodo do "torräo impermeabilizado com parafina". Foram utilizadas amostras indeformadas de solos e arena, eada uma pesando em média so gramas. A amostra foi amarrada com un fio de cobre ja etiquetada e en seguida impermeabilizada atraves de 3 rapidas imersôs em parafina fundida a 8000 . Apos estriar a parafina, a amostra foi pesada e em seguida pesada nowamente porém, imersa en foga. o procedimento seguinte foi a retirada da parafina da amostra para pesack a d mida e seca na estufa a 1100c. Una vez obtido todos os elementos para o cálculo da densidade aparente, utilizou-se a fórmula adotada para o método da parafina:

$$
\begin{aligned}
& (P 1-\cdots(P f+P \text {. }
\end{aligned}
$$

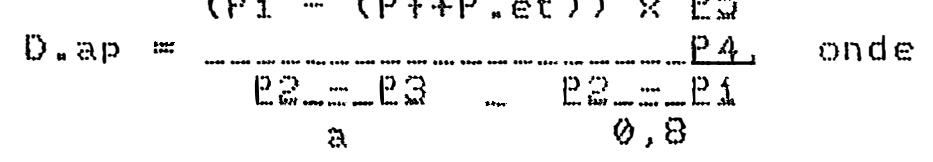

$$
\begin{aligned}
& \text { P.f }=\text { Peso dofio de cobrei } \\
& \text { P.et := peso da et i meta; } \\
& \text { PI = peso dotorrato+P.f+P.et; } \\
& \text { Pa }=\text { PEso do torräo parafinado }+ \text { P. } f^{+}+ \\
& \text {P.et; } \\
& \text { P3 = PEso do torräo parafinado }+P \text {. } f+ \\
& \text { P.et, imerso en agua; } \\
& \text { pa = peso do torrato desparafinado; }
\end{aligned}
$$




$$
\begin{aligned}
& \text { Ps }=\text { peso do torräo seco a } 1100 \mathrm{C} ; \\
& 0,8=\text { densidade da parafina; } \\
& a \quad=\text { densidade da agua. }
\end{aligned}
$$

- Porosidade - A porosidade foi determinada atraves o metodo indireto, utiliando a seguinte formula (EMBRAPA - 1979):

Porosidade total $=100$ (densidade real densidade aparente)/densidade real

- Fracionamento granulométrico da materia orgânica - Foi realianda nas amostras de solo que apresentam teores acima de $0,5 \%$ de carbono total. 0

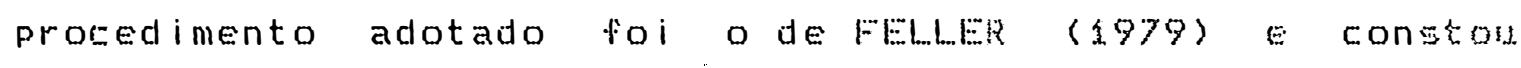
inicialmente da dispersä́ das amostras agitando-as em ádua destilada, da aplicacio do ulorasom, da separacăo em tamises de 0,05 e $0,2 \mathrm{~mm}$, da dosagen do carbono nas fracues de $0-50,50 \cdots 00$ e $200 \cdots 2000$ por via seca, utilizando o equipamento carmograph da segáo de Química do solo do CENA.

\subsection{3-Análises quimicas das amostras de soloe arena.}

- ph en água - Determinado pelo metodo potenciometrico na suspensäo de log de amostra de solo TFSA em 2ejml de água destilada com tempo de contato nunca inferior a 1 hora $e$ agitacäo da suspensäo antes de mergulhar os eletrodos para proceder a leitura.

- PH en KCl IN - Determinado através do potenciometro na suspensäo de jog de solo TFSA em eEni de 
cloreto de potassio IN, pHY adotando-se o mesmo procedimento para a determinac̆ö do pH em água.

- $\triangle p H$-... Calculado através da diferenga entre os valores do pH em KCl iN e pH em HeO.

- Carbono total - ocarbonototal foi determinato por via seca através do equipanento CARMOGRAPH, tendo sido utilizado em media 300 miligramas de amostra de solo e arena moida passata na peneira de matha $0,25 \% \mathrm{~mm}$.

- Nitrogênio total -o Determinado pela digestä́o de O, Ëg de amostra de solo TFSA, com fmi de uma solucäo contendo ácido sulfúrico concentrado + águá oxigenala + sulfato de Iitio + selento em po " Apos digestäo durante G horas, procedeu-se a diluicáo para 7 giml e em seguida procedeu-se a leitura no auto analisador de fluxo continuo. Após a leitura dos gráficos procedeu-se o calculo do teor de nitrogennio via computador.

- Fósforo assimilável a p freforo assimilavel foi determinado pelo método colorimetrico na presenca do ácido ascorbico, utilizando como extrator a

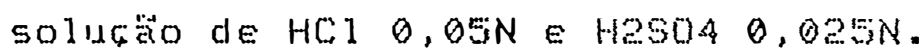

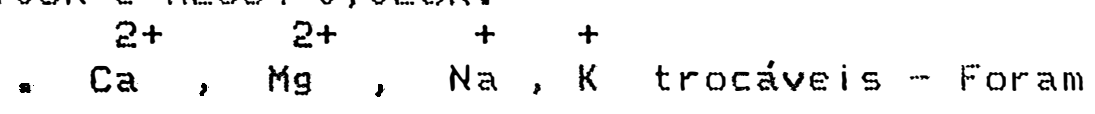

extraidos pelo método do ácido cloridrico o, OsN e dosados por absorcáo atomica e fotometria de chama.

- Soma de bases - " $S "$ - Foi obtida através

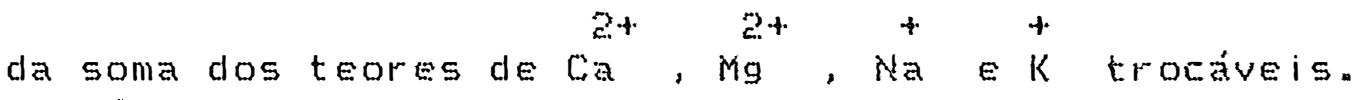

- Acidez trocável - Extraída pelo método 
do cloreto de potássio iN e titulado com solugăo de $\mathrm{NaOH} 0,0 \mathrm{esN}$, utilizando como indicador a fenolftaleina. $+3$

- Al trocável -Foi utilizado o mesmo

extrato para a acidez trocável, acrescentando-o $4 \mathrm{ml}$ de fluoreto de sódio e a sua titulacăo com MCl 0,0 ân.

* H trocável - Calculado pela diferenga entre os valores da acidez trocável $\left(^{+}+{ }^{3+}+A^{+}\right)$do $3+$ Al trocável.

- Capacidade de troca de carions ... "CTC"

- Foi calculada pela soma das bases trocḱveis e acidez trocádel.

- Saturacäo de bases - "U*" - Foi

calculada atraves da formula: $V=100 S / C$ TC.

$$
\text { 3.4.4 - Análises quínicas da soluctöo do solo. }
$$

* PH - Foi determinado diretamente na solutấo do solo, utilizando o método potenciométrico com duas repeticöes na leitura.

- Teores de NoB, Nos, so4, ci, si, NH4,

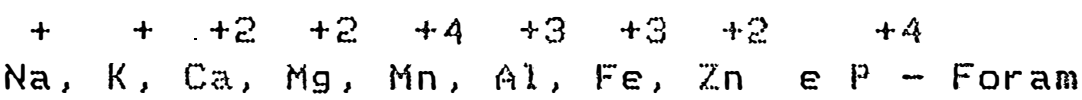
todos dosados no laboratório da segäo de Radioguimica do Centro de Energia Nuclear na Agricultura - CENA/USP, utilizando o espectrômetro de emissäo atômica com plasma induzido de argônio e o espectrofotônetro de absortäo atônica.

$$
\text { 3.4.5 -- Balanco iŝnico da solucäo do solo. }
$$


objetivando realizar o balanco iśnico da solugäo do solo, os teores em profundidade dos ions dosados, foram transformados de mg/l para $\mu$ mol/l e en seguida para $\mu \in q .1$. Após as transformagöes dos dados, foran realizados a soma dos ânions e cations $E$ a sua diferenca quantitativa.

$$
\text { 3.4.6-Análige termodinamica da solufäo do solo. }
$$

Foi realizado um estudo termodinânico da solucáo do solo para analisar os equilibrios dos minerais de neoformacáo, a partir dos valores de PH da solugáo e suas concentrafís en Sida, Na, $K$ e Ca, utilizando modelos desenvolvidos por PEDRO (1969) $E$ TARDY (1969).

\section{4 .7 - Análise mineralógican}

- Difragáo de raiosiox

Foram analisadas as fracóes argila, e silte das amostras de solo e arena. Processou-se 'iniciālmente a remogáo da matéria orgânica das amostras superficiais, utilizando H202 a $30 \%$ segundo o procedimento de JACKSON (1969), seguida pela dispersão com NaOH, peneiragen úmida para separafáo da fracáo areia $e$ a centrifugacáo para a separacáo da fracáo silte da argila. Após o fracionamento granulométrico, as três fracöes foram colocadas para secagem na estufa com temperatura inferior a 60oc, até que as fracóes silte e argila atingissem o estado pastoso para serem distribuidos en finas camadas 
sobre lâminas de microscópio, com o auxilio de uma Espátula.

Após a secagem em temperatura ambiente, as amostras foran submetidas à irradiagáo de raios-X no intervalo de 3 a $300(2.0)$ utilizando um aparelho RIGAKU com tubo de cobre como fonte de radiagäo e operando nas seguintes condigïes: range $=100-48, T C=1$, scan-speed $=$ 2. $K V=40 E M A=20$.

Nos difratogramas de raios-X obtidos, procedeu-se a medicáo dos espacamentos entre os picos registrados em graus 0 e a conversáo para espaganentos atômicos en A utilizando a tabela padräo para radiacáo de cobre.

A identificacáo dos minerais presentes na fracäo argila e silte foi realizada através das comparafós dos espacamentos atônicos em a registrados nos difratogramas com os valores das tabelas contendo o espacamento padráo de difragáo dos minerais.

\section{4 .8 - Análise micromorfol siga.}

- Impregnacáo com resina e laminacáo: - Para a realizacáo da análise micromorfológica, as amostras indeformadas de solo, arena e rocha parcialmente alterada foram todas submetidas as impregnagöes con resina plastica. As amostras foram inicialmente lapidadas em formato e tamanho conveniente, preservando através das anotacóes de campo, a posicáo $e$ a or ientagáo das mesma no 
campo, afim de que esses parânetros de fundanental importância, fossem considerados nas anklises micromorfologicas en secöes delgadas confeccionadas a partir dessas amostras impregnadas.

B procedimento seguinte foi o acondicionamento das amostras en recipientes de vidro de $150 \mathrm{ml}$ e a secagem das mesmas en estufas com temperatura controlada nunca superior a $600 C$ e por um periodo de una semana.

En seguida, as amostras foram colocadas num dessecador e submetidas à impregnagáo, adicionando lentamente una mistura contendo $350 m$ de resina POLILYTE T-208 + 150nl de monâmero de estireno como dissolvente +3 gotas de catalizador PEROXOL - 6 io (peróido de metil-etil acetona) $e$ a aplicacáo de vácuo equivalente a $15 m m$ de $H g$ de pressäo por um periodo de 5 minutos, para a eliminacáo total do ar das amostras.

Após inúmeras aplicagóes de vácuo e a imersåo total das amostras na resina, finaliza-se a impregnagáo deixando en repouso por um periodo de três semanas para completar a polimerizacáo e o endurecimento total de mistura e a partir dai, fez-se a fatiagáo e o polimento com o carborundun até se obter una secâo de aproximadamente 30 microns de expessura.

A análise e a descrigâo das segões delgadas foran realizadas de acordo con o método e nomenclatura estabelecidos por BREWER (1964) e BULLOCK et alii. 


\section{RESULTADOS E DISCUSSÃO.}

\section{1 - Os materiais de partida.}

Neste item seráo apresentadas as principais caracteristicas dos materiais de partida ol de transformagăo. Sera considerado inicialmente a matéria mineral, que é uma rocha granitica, eposteriormente a matéria orgânica constituida pela biomassa aérea e a liteira.

\subsection{1 - Material mineral: o granito.}

o material mineral se apresenta na forma de um macico granitico com alta densidade de matacbes aflorantes, predominando formas arredondadas e de tamanho variado, porém a maioria com mais de a metros de dianetro.

$$
\text { A superficie dos matacies, é }
$$

predominantemente lisa, outros com faceis cavernosas com esqueleto de quartzo. As faceis cavernosas que se formam na superfície de alguns matabes säo causadas peio intemper ismo que se processa nos minerais mais facilmente intemperizaveis que neste caso säo os feldspatos e a biotita, permanecendo os minerais de quartao.

Normalmente as fissuras dos matacises estáno preenchidas pela matéria orgânica que pode ser produto consequente do desenvolvimento e morte de organismos gue ai encontram un ambiente favoräel ao sed estabelecimento, como também, pode ser matéria orgânica introduzicia pela água pluvioliniviada do dossel florestal. Além das 
fissuras, ocorrem com certa frequência capas de esfoliacáo dos matacíes e sob essas capas há tambén a acumulacáo de matéria orgânica em quantidades variadas.

Este granito näo apresentol variabilidade macroscópica quanto ap seu tipo, em todas as trincheiras abertas nas duas topossequências de solos. Apresenta uma estrutura equigranular grosseira com cristais de quartzo feldspato bem desenvolvidos.

A análise microscópica da secăo delgada desta rocha, permitiu identificar os seguintes minerais: quartzo, plagioclasio, microclina e a biotita.

- quartzo é o mineral dominante que aparece em gräos isolados. Em alguns casos, verificamse a geminacăo devido ao agrupamento de vários gräos de quartzo, cada un com orientacáo bitica diferente. En todas as secies delgadas analisadas näo se observou a sua alteracáo, mas foram detectados alguns cristais fissurados e alguns deles, ten suas fissuras preenchidas com naterial importado, principalmente o Gido de ferro.

A microclina, que é outro mineral essencial que constitui este granito, ébastante abundante, ocorrendo às vezes na forma de gräos complexos juntamente com o quartzo, idêntica à geminacão do plagioclásio e quartzo. Observa-se tambén a microclina com intrusăo de plagioclasio zoneado e um pouco alterado apresentando a formacáo de sericita. Percebe-se nas secís delgadas da rocha que os cristais da microclina se mantém 
ainda intactos.

$$
\text { 0s plagioclasios, apresentam diversos }
$$

planos de clivagens, sendo alguns, perfeitamente paraledos. observase que alguns minerais de plagioclasio esta parcialmente zoneados, outros com manchas escuras no centro do mineral, em consequencia do infoio da sua alteracáo, em profundidade, para a sericita e epfoto, sendo este em menor proporzano da sericitan

A biotita tambem constitui outro mineral essencial deste granito, apesar da sua quantidade ser bem inferior em relatio a dos feldspatosn os minerais intastos apresentam coloragaro martom escura, enguanto aue os

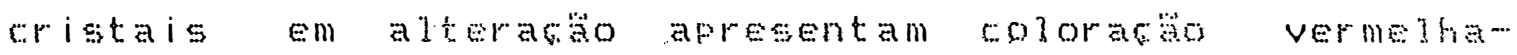
amaredada.

$$
\begin{aligned}
& \text { 4.1.1.1 - Genese das arenas graniticase } \\
& \text { suas transformacies mineralo- } \\
& \text { gicas. }
\end{aligned}
$$

As arenas constituem uma teiço tipica do intemperismo de rochas granitioasem climas temperados, segundo COLbTER (1961), citado por MELFI \& CERRI (197A), näo sendo portanto, comm sua ocorrencia em regiöes tropicais, onde a intensidade dos agentes do intemperismo provoca fortes transformacoses mineralosicas dando or igem a grande guantidade de minerais argilosos.

Nas arenas graniticas ainda se observa a estrutura do granito, pois a evolusio aúmica do material de origem É incipiente. Este fato contrasta coma 
quase total desagregagato e individualizacto dos minerais primários da rocha matria (MELEI \& CERRI, 1974).

SEgundo MELFI \& CERRT $(1974)$, a formacäo das arenas granticas esta condicionada ao comportamento dos peldsatos no pransorrer do intemperismo, ja que o quarta mostra-se bastante estavel nas condicoes superficiais, en funcero da sua elevada resistencias ao intemperismo. Dependendo das condicies termohidricas, a alteracio dos feldspacos pode dar origem a uma grande variedade de produtos minerais secundarios neoformados, fornecendo desta mansira, as princibais caracter faticas quato ao tipo de material intemperizado.

observa-se na arena granitica. que o quartao continua a ser o mineral dominante e há uma tendencia a se acumblar progressivamente no pertil de alteracäo devido a alta estabilidade apresentada por seus cristais, mesmo frente d actä dos agentes de intemperismo presentes. Näo se percebe modificaces quimicas nos cristais do quartao, mas percebe-me sua desagregacaco fisica atraves do processo de fraturamento, tornandowos menores. o processo da fissuracäo tambem é evidente em alguns oristais do quartzo, favorecendo a importaca de bridos de ferro nessas fissuras.

Nas arenas o desaparecimento do plagioclásio é quase que total, aparecendo commente seds pseudomor fos. Segundo MELFJ \& CERRI (197A) o plagioclásio é um dos minerais que apresenta menos resistencia à aca do 
intemperismo, consequentemente é um dos minerais responsáveis pelo alto teor de minerais secundários no material arenizado.

A alteracäo dos feldspatos inicia-se, segundo MEleI \& CERRT (1974), a partir dos primeiros estagios do intemperismo dogranito e a sua evolucäo pode ocorrer em duas direcbes distintas. Uma, de ocorrencia relativamente rara no perfil de alteracao, proporciona a formacäo de pequenas quant idades de gibbsita, que se desenvolvem epitaxicamente sobre seus cristais e que em funçón da sua reduzida quantidade, as suas reflexbes nöo săo detectadas aos raios-x, mas säo perfeitamente bserváveis em secsobs delgadas. outra evolucaro mais frequente a alteracá para minerais caoliniticos, atraves de uma fase amorfa, que facilmente observivel logo no inicio do intemperismo dos granitos. Assim osplagiocläsios passam a exibir nas suas fraturä, um material de preenchimento isbtropo com comportamento de material amorfo e com a progressäo da alteracato estes geles passan a ocupar um maior volume dos seus cristais evoluindo finalmente no sentido de permitiren no seu seio a lormacäo de cristalitos de minerais do grupo da caolinita, perfeitamente caracterizados aos raios-X e ATD.

MELFI \& CERRT (1974), sal i Entam que na arena granteica, os plagioclasios podem ainda conservar sua forma caracteristica porem, quimicamente e estruturalmente estäo transformados em minerais do grupo da caolinita, explicando desta maneira a alta porcentagem de 
argidominerais no material de alteracäo en contraste coma baika porcentagem da frasian argita nos solos neoformatos. Tal fato ocorre porque, os minerais caoliniticos säb mito estaveis nas condicoses de desenvolvimento do perfid, aumentando suas coneentrabose no mastrial areniando e por outro lado, ocore sua relativa diluisto nosolo em funcato do fenomeno de lixiviaso ane ocorem nos hor arones superficia is.

Conforme observaram MELFT \&

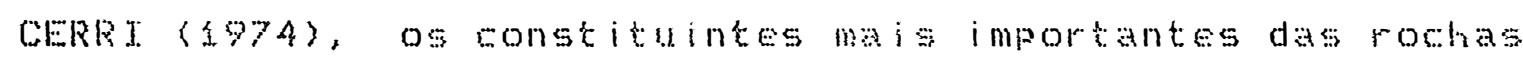

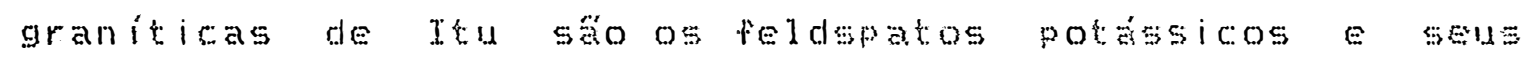
cristais se mantem intactos nos primeiros estagios de formacio da arena e permanecem ate nos horiacones superficiais do pertil, sempre em concentrabes relativamente levadas.

A alteracio dos teldepatos potásicos se processa, segundo miblar \& CERRt (1974), de maneira análoga à dosplagiocläsios, diferindo somente na velocidade de alteracioe inexistencia do transformago direta em gibbsita. A modificaco mais importante aue se observa inicialmente, é a formacoso de sm imortante sistema de fraturamento e essas fraturas säo simplesmente revestidas por material ferminoso esomente nos estagios mats avancados da alteracäo, há desenvolvimento dos produtos amortos.

CLEMENTE $\{1988\}$ estudando as alteracos de plagioclasio de rochas ácidas da formaga 
Serra Geral nos Planaltos de Guarapuva e Palmasple, observa que os cristais maiores de: plagioclásios se alteram diretanentsem abbsita, enquanco que os menores passam por uma fase amorfa para depois resultar em gibbsita ou em gibbsita t caolinita.

SEgundo MELFI \& CERRI (19\%A), a biotita quase sempre associada a pequenas quantidades de clorita, apresenta un comportamento particular no transcorrer da alteracăo do granito pois, seus eristais micácos permanecem ate nos hor izontes superficiais do solo, apesar das suas modificacbes quimicas es estruturais ao longo dat evoluc:ăo.

$$
\text { Os estágios inimiais da }
$$

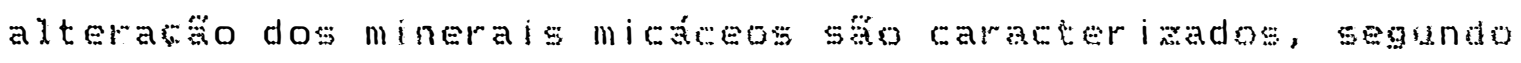
MELFI \& CERRI (1974), por perdas pareiais de ferro, ligeira

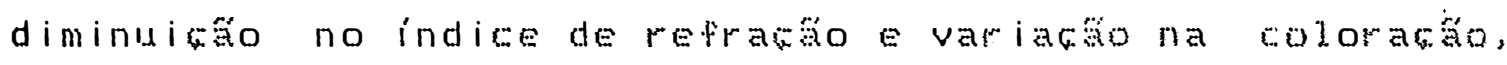
tornando-os mais amarelada. submetidus aos räios-x, apresenta acentuada diminuigúo da replexaro caracteristica da cilorita e conservatáo e mesmo intensificacáo da retlexáo $10 A^{\circ}$

\subsection{2 - Material orgânico: biomassa aérea e liteira.}

A matéria organica constituinte de ua solo, provem principalmente da biomassa aterea constituida pela vegetacäo que deposita suas folhas e ramos no solo formando a litieira.

-Bionassa aérea: A vesetacáo da área 
estudada ainda se encontra intacta (floresta), e e constituida por dois estratos vegetativos, sendo que o superior é constituido por árvores de porte médio e fino, e de altura maxima em torno de 30 metros com densidade náo mito alta de arvores, fato este, que pombibita a incidencia da radiaga solar diretamente sobre a superficie do solo, durante uma parte do dia. Was arvores de maior porte verificamse a ocorrencia espordica de lianas. Tamben algumas especies de palmeiras compöen este estrato. 0 segundo estrato, que 0 "estrato inferior" s constituido por plantas rasteiras de diversas especies.

-Liteira: Com relacăo à liteira observouse que a mesma é constituida por follas e ramos com uma grande portaro a inda intacta, outra parcialmente decomposta e outra porcăo ja totalmente decomposta, apresentanoo coloracäo preta. observa-se também com bastante frecuencia, troncos de arvores en vários estaglos de decomposiaño.

Esta liteira, é pouco espessa, com apenas alguns centimetros e esta deposibada sobre una superficia de solo bastante cascalhento conforme mostra a análise granulometrica, cujos dados constam na Tabela ob. Säo observados tambem, com alguma frequencia, fragmentos de carväo somente na superficie do solo.

As amostragens sistematicas desta liteira, realizadas en diversas áreas de i metro quadrado ao longo da topossequencia NA, permitiram a sua determinacăo quant itativa, ou seja, 9,61 ton/ha. 
4.1.2.1-Evolucäo dos constituintes orgânicos depositados no solo pela liteira.

0 teor e distribuifato em profundidade de Carbono e Nitrogênio, assim como, a relacăo C/N dos quatro pertis estudados están apresentados na Tabela 3 e Figuras 12 e 13.

Verifica-se que em todos os perfis analisados: os maiores teores em carbono e nitrogénio se concentram na camada superficial, ou seja, nos primeiros 10 cm, com $3,36 \%$ e $0,36 \%$ respectivamente. A tendencia verificada é que seus teores bendem a decrescer até os ey cm de profundidade de maneima abrupta e, lentemente até os $80 \mathrm{~cm}$. A partir dat, os teores se mantem aproximadamente constante em niveis bastante baixos, atingindo 0,16 a $0,02 \%$ para o carbono e de 0,04 a 0,03\% para o nitrogenio, na profundidade aba $i$ o de $200 \mathrm{~cm}$.

Deve-se ressaltar que entre os quatro perfis analisados, o perfil denominado NAs, apresentow os maiores teores com $3,36 \%$ e $0,36 \%$ de carbono e nitrogenio respectivamente nos primeiros $10 \mathrm{~cm}$ de profundidade (horizonte A11) e $0,16 \%$ e $0,04 \%$ a 100 - $110 \mathrm{~cm}$ de profundidade (horizonte ce), mesmo coniziderando que é o perfil mais raso e localizado na parte mais elevada da topossequencia NA, sob mesma cobertura florestal. Os demais pertis também apresentam teores altos de carbono e nitrogennio nos seus horizontes superficiais, com valores 


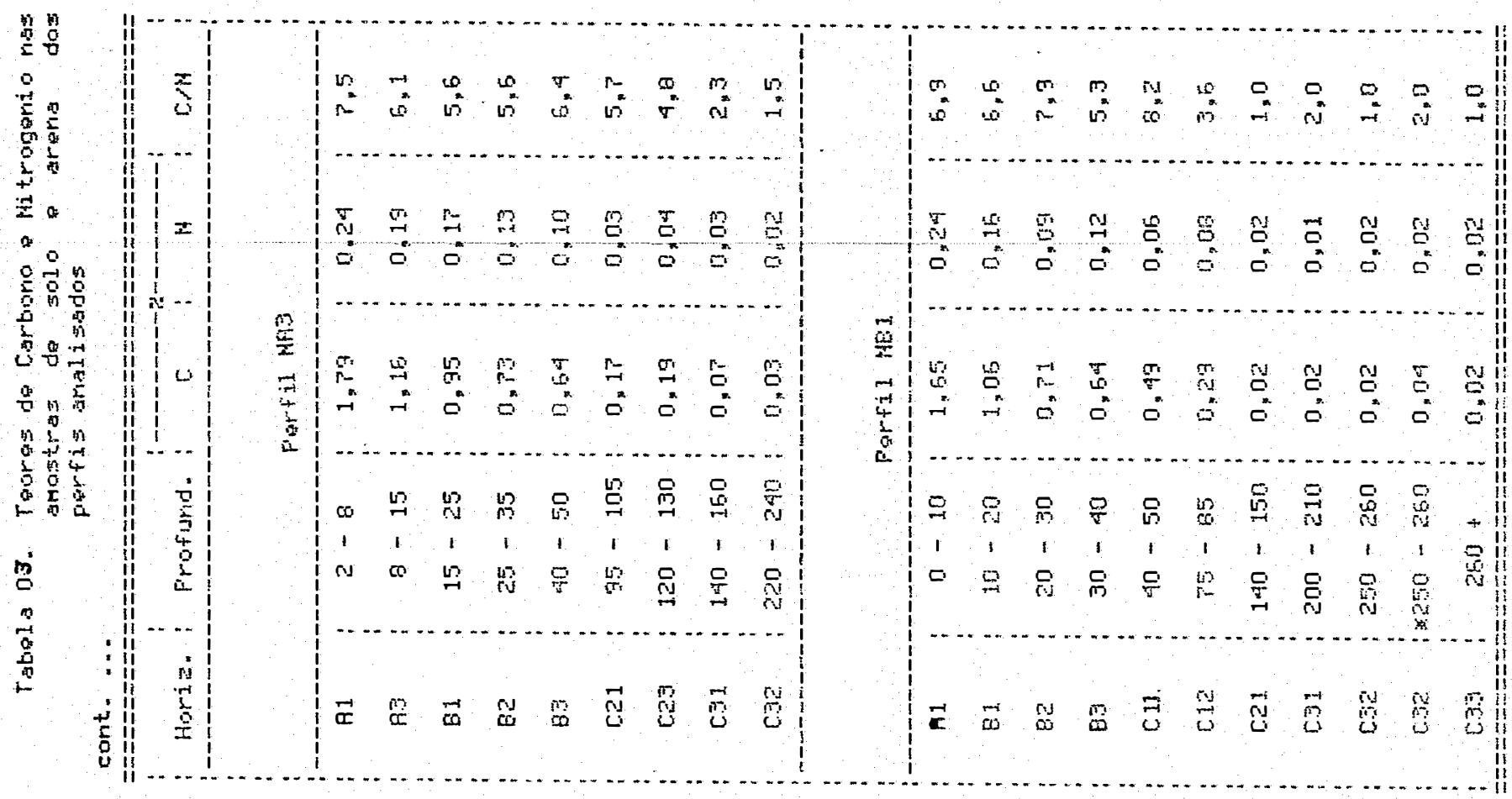

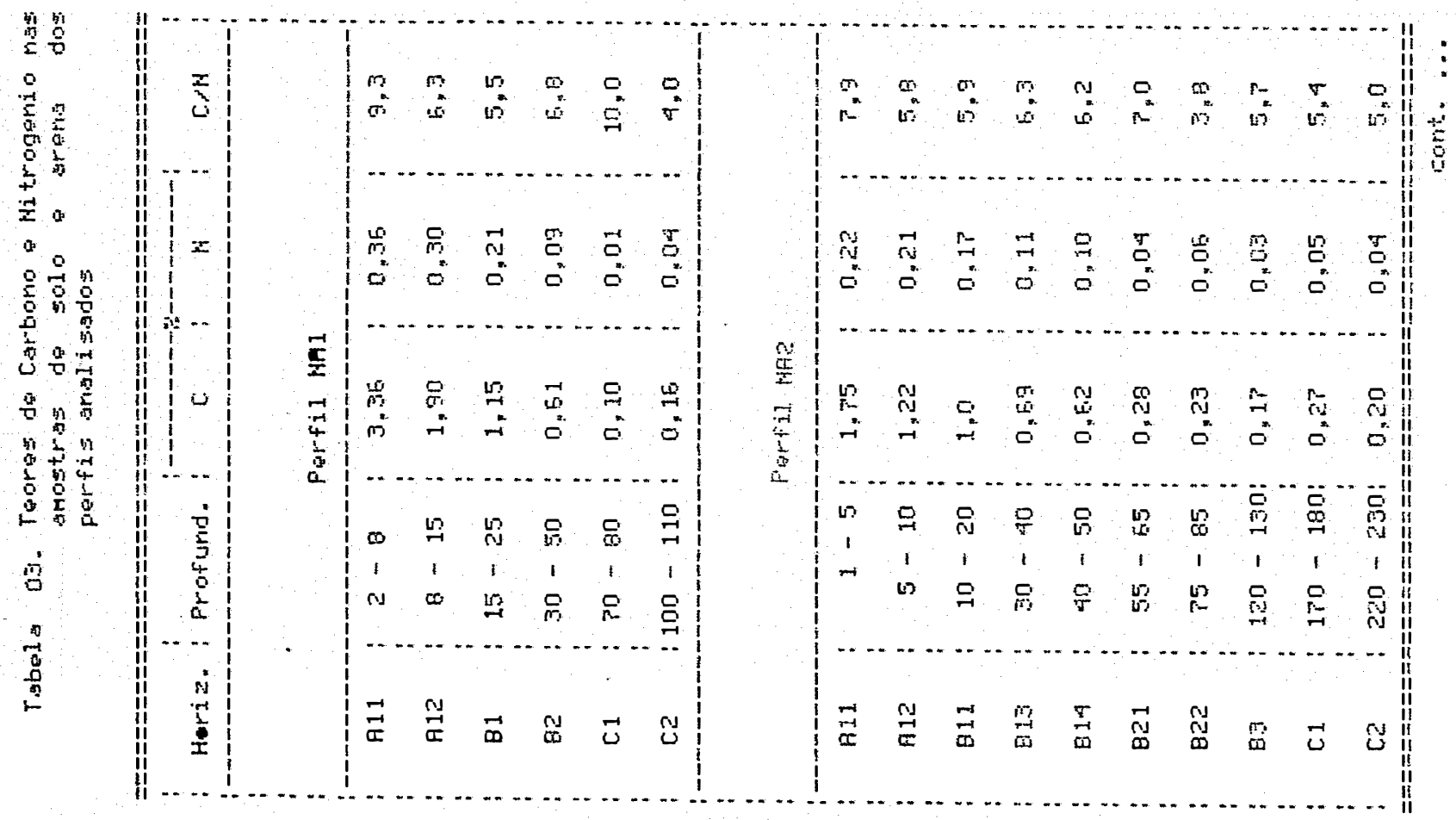




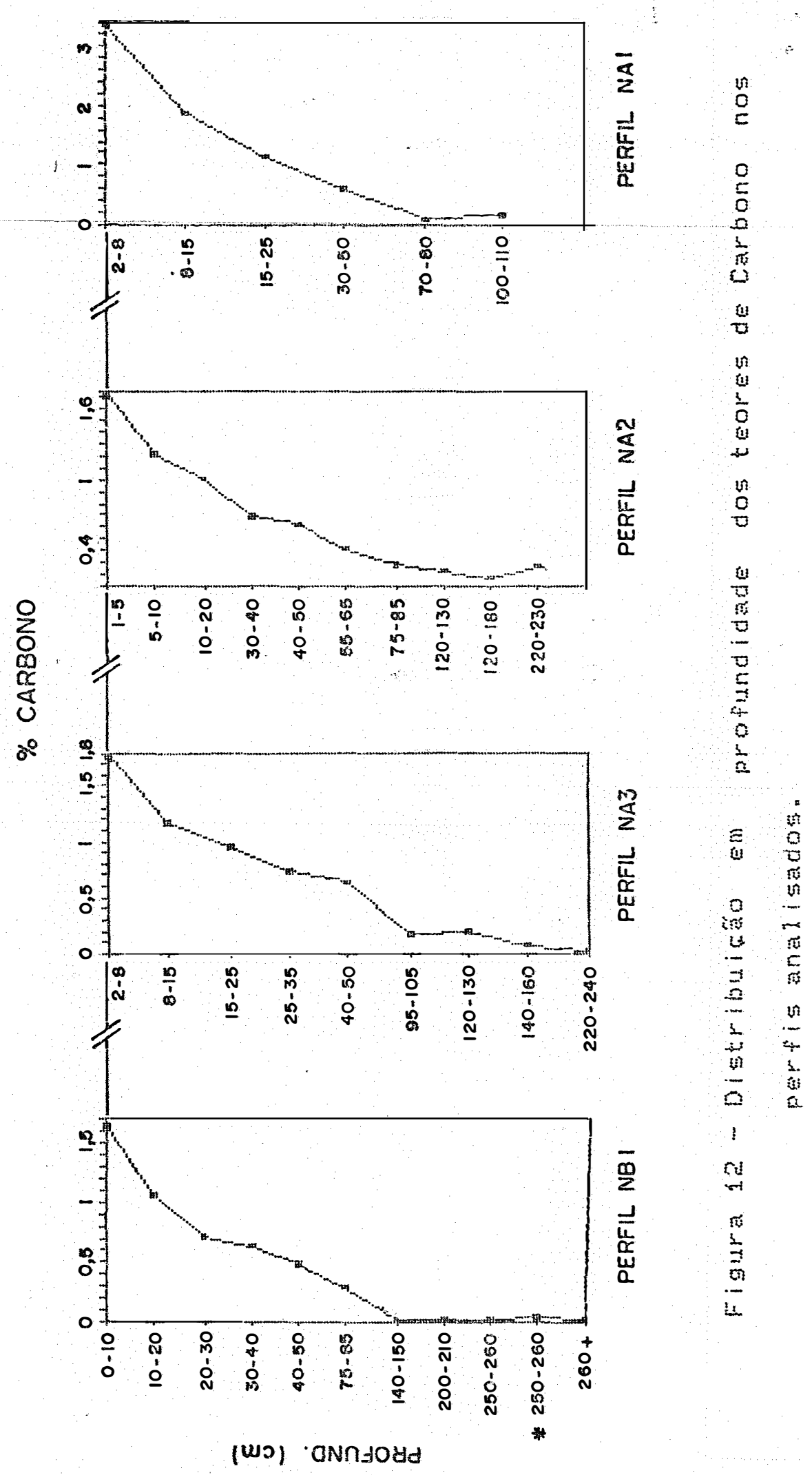




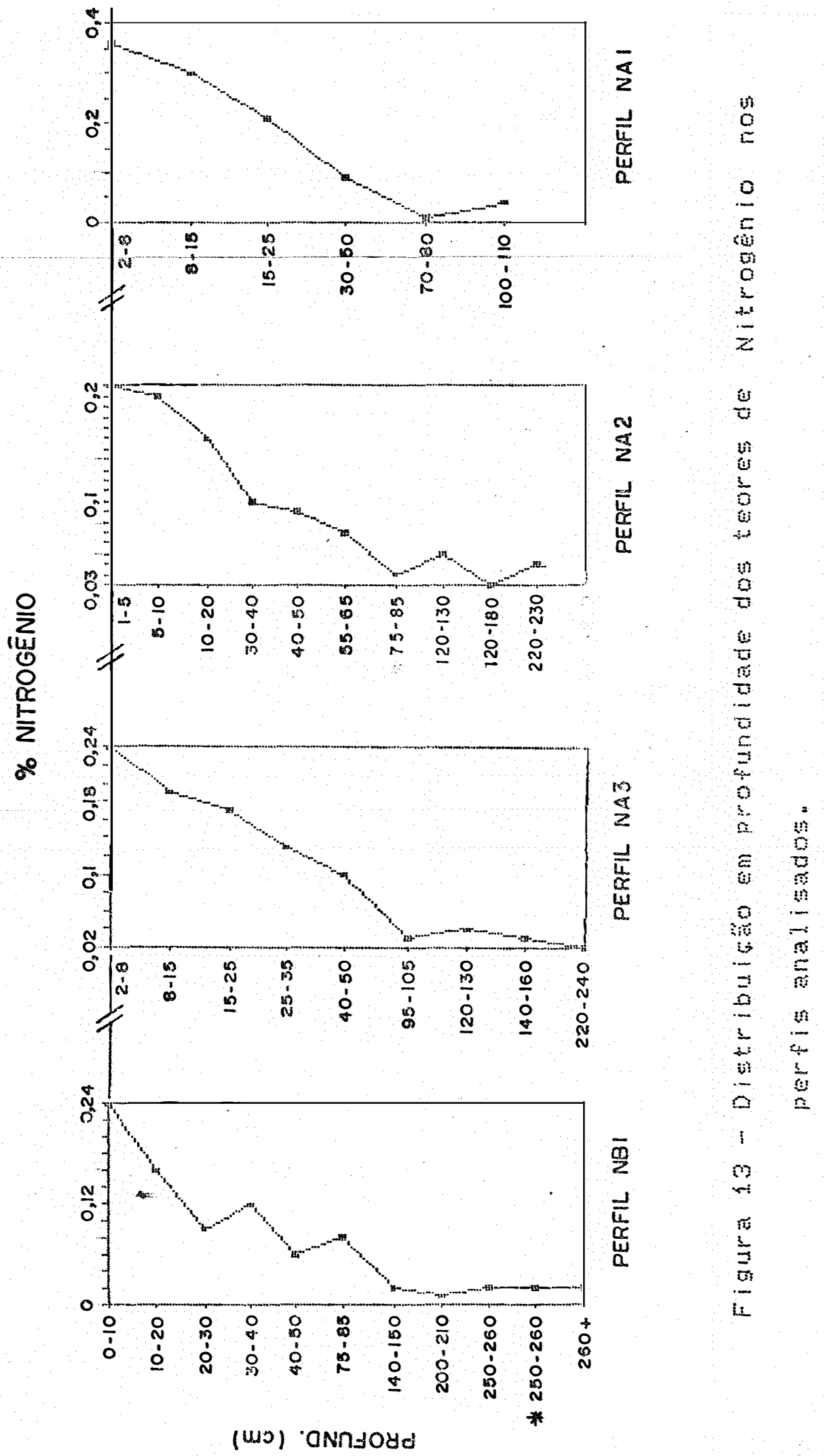


acima de $1,65 \%$ e, $22 \%$ respectivamente.

Apesar dos teores de Earbono e nitrogenio serem baikos em profundidade, conven observar que esses teores sáo bastante expressivos principalmente nos hor izontes dominados pata arena gramitica, signiticando que as suas migracies se processam mesmo diante da pouca permeabilidade da arenan

A relacáo C/N apresenta valores baikos, ou seja, valores abixo de a mesmo nos homizontes superficiais. Tais dados indicam que a maior parte da materia orgânica desse solos já se encontra completamente humificada, conforme demonstra o fracionamento granulometrico da mesman

A tendencia observada nos pertis analisados é pelo decrescimo gradativo em profundidade, da relacáo CoN o acréscimo abruptico da relacáo $C / N$ observado no horizonte C. (70-30 cm) do perfil NA1, deve-se ao provável erro analitico na determinacäo do nitrogênio.

0 fracionamento granulométrico da matéria orgânica foi realizado objetivando identificar os percentuais do carbono nas fracies correspondentes aos residuos vegetais näo humificado com dimensies maiores que 200 um (matéria leve) como também, na fracáo maior que so um constituida pelos residuos vegetais pouco humificado e na fracáo (menor que $50 \mathrm{um}$ ) dos compostos húmicos e organow minerais. No processo de fracionamento da matéria orgânica foi utilizado o método de FEllak (1979), cujos resultados săo apresentados nas Tabelas 04 e 


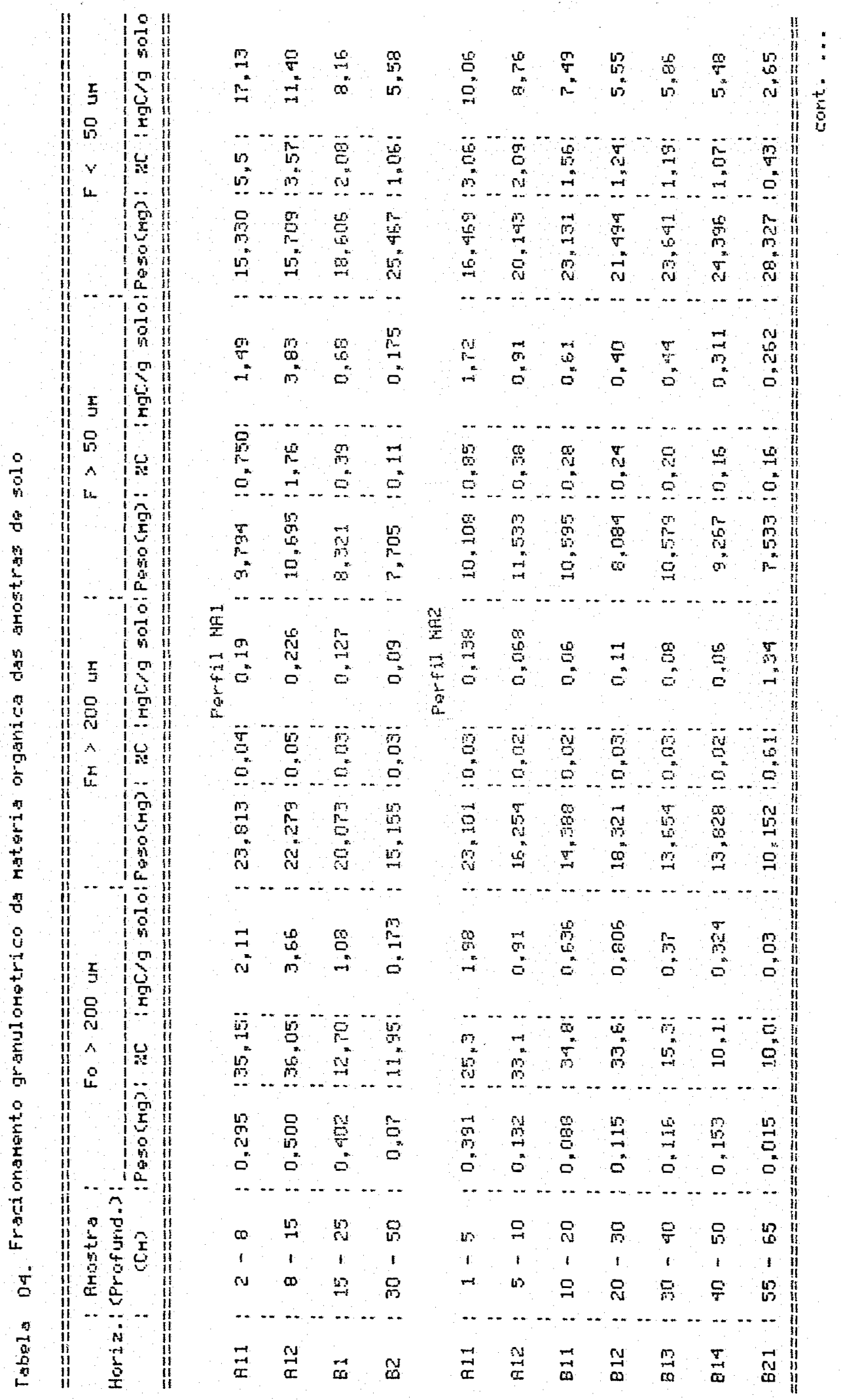




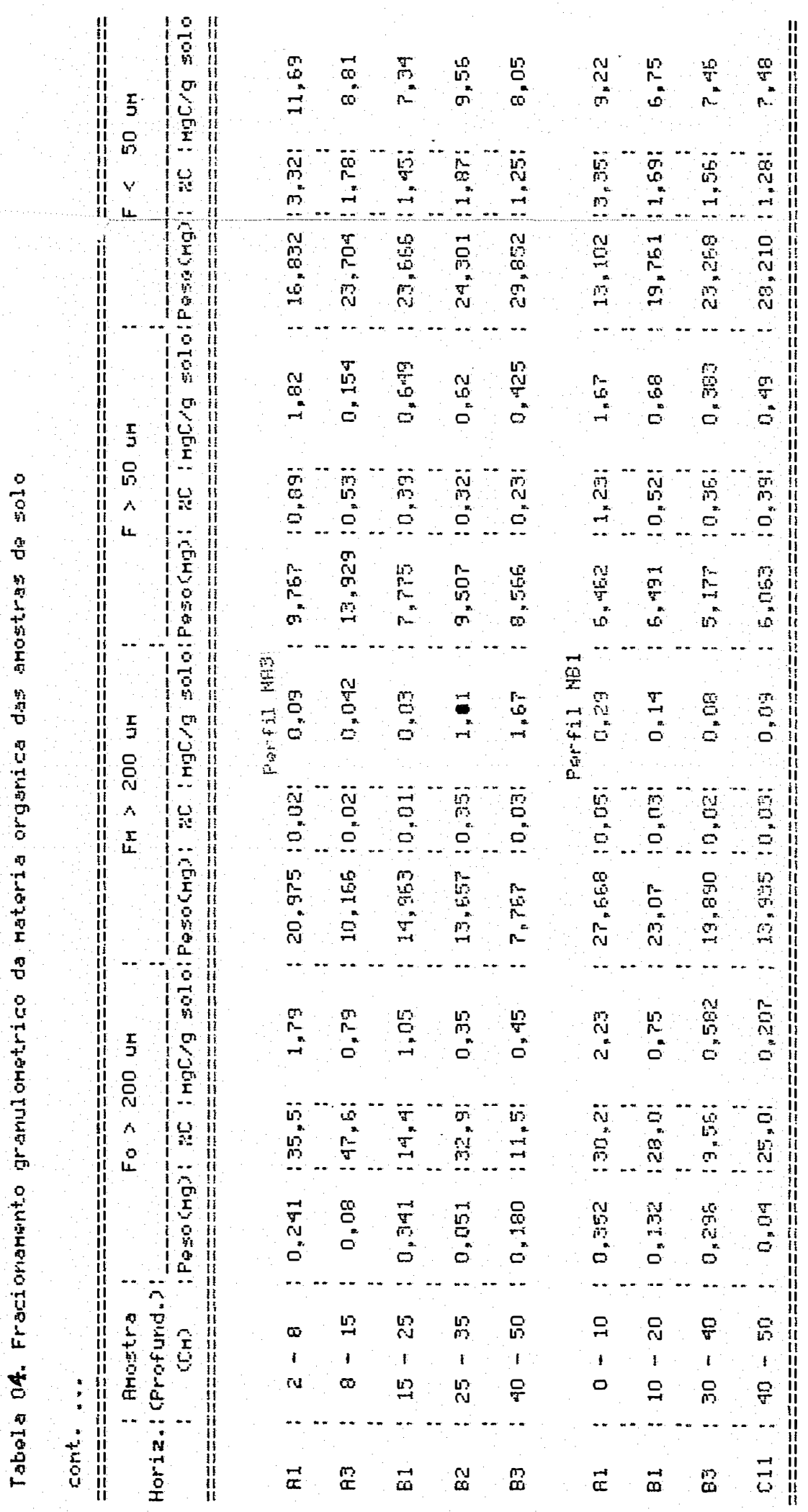



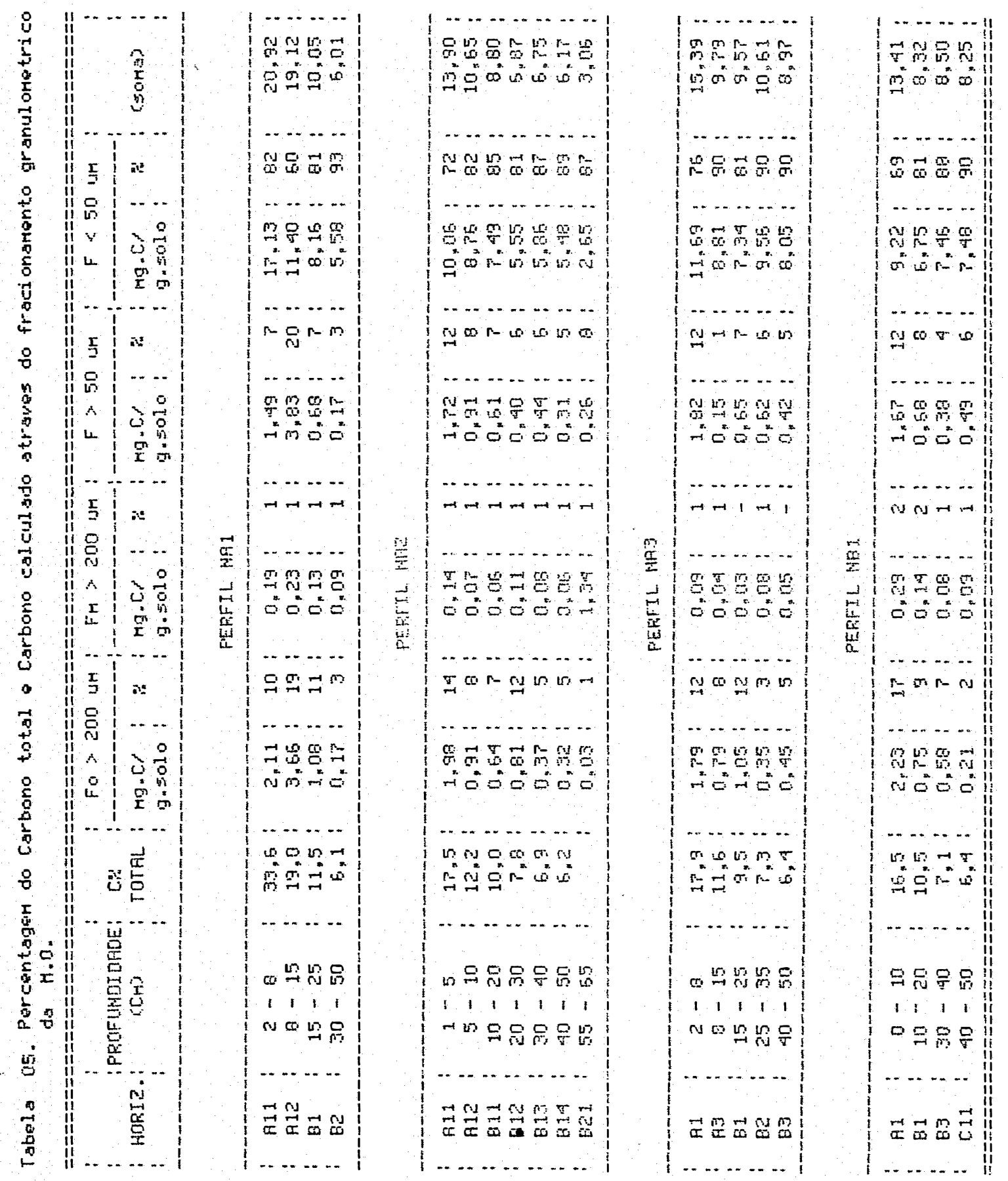
Conforme se observa na Tabela 0 A e 05 , o percentual mais eleyado de carbono je encontra na fracáo húnica e dos compostos organominerais (fracóno $(50$ um). Assim sendo, o pefil NA1 mostra que o sel horizonte A1.1 $(0-8 \mathrm{~cm})$ apresenta $82 \%$ do sul carbono sob a forma de humbs e compostos organominerais, $7 \%$ sob a forma pouco humificada e apenas 10\% sob a forma de pesiduos vegetaisem alteracäo mas näo humiticado (matéria leves. Esta proporcionalidade em termos do teor de carbono na fracto $<5014 \mathrm{~m}$, tende a aumentar em protundidade, e coviamente, noutras fracoses oteor de carbono tende a decrescer em profundidade principalmente sob a forma de material pouco humificado. Com paquenas variabes, tais fatos ocorrem nos demais pertis NA2, NA3 E NB1, significando que os compostos húmicos migram en propundidade atingindo os horizontes do solo e arena mais profundos. Segundo RODRIGUES (2984), a concentragäo do humus nos hor izontes superficiais e sua diminuigáo em profundidade indicam que as moléculas organicas, precursomas das substancias húmicas permanecem em grande parte na superficie e migram pouco em profundidade. As que migram, säo constituidas pelos oximidroxidos e argilas, mais soliveis e menos sensiveis as barreiras fisicomquicaz. Assim, segundo esse mesmo autor, há uma separacáo dos precursores para a formacäo de dois tipos de hímss, sendo o primeiro concentrado na superticie sod forma de fracós alcalinosoluveis e humina e o sesundo tipo em profundidade, 
condensado sob a forma de ácidos fílvicos livres " Também VOLKOFF \& CERRI (1981), citadOS por RODRIGUES (1984) afirman que as moleculas polimerizadas, podem despolimerizar-se produzindo moléculas menores que se movimentam en profundlade onde nornalmente se polimerizam, sob condifäo alternadas de umedecimento e secamento.

4.2 - Produto da evolugäo mineral e orgânica: os solos. 4.2.1 - Fase solida. 4.2.1.1-Mortologia.

Forali abertos quatro pertis, sendo três localizados na topossequencia NA (Figura 14) caraterizados como NA1, NA2, NA3 e umperfil distante 600 metros desta topossequência, cendo sido caraterizado como NBi.

0 perfil NAś é constituido por um solo raso tendo a rocha subjacente alterada a bocm de profundidade. Já os perfis NAz e NA3 sä́ constibuidos por solos um pouco mais evoluido, sendo gue os mesmos se local izam na parte mais baika da topossequencia. Na outra topossequência denominada NB, foi analisado um perfil caracterizado como NB1. Este perfil é constituido por um solo cambissolo bem caracterizado pois apresenta a arena ben tipica, resultante da alteracäo do granito denominado Telos pires. 


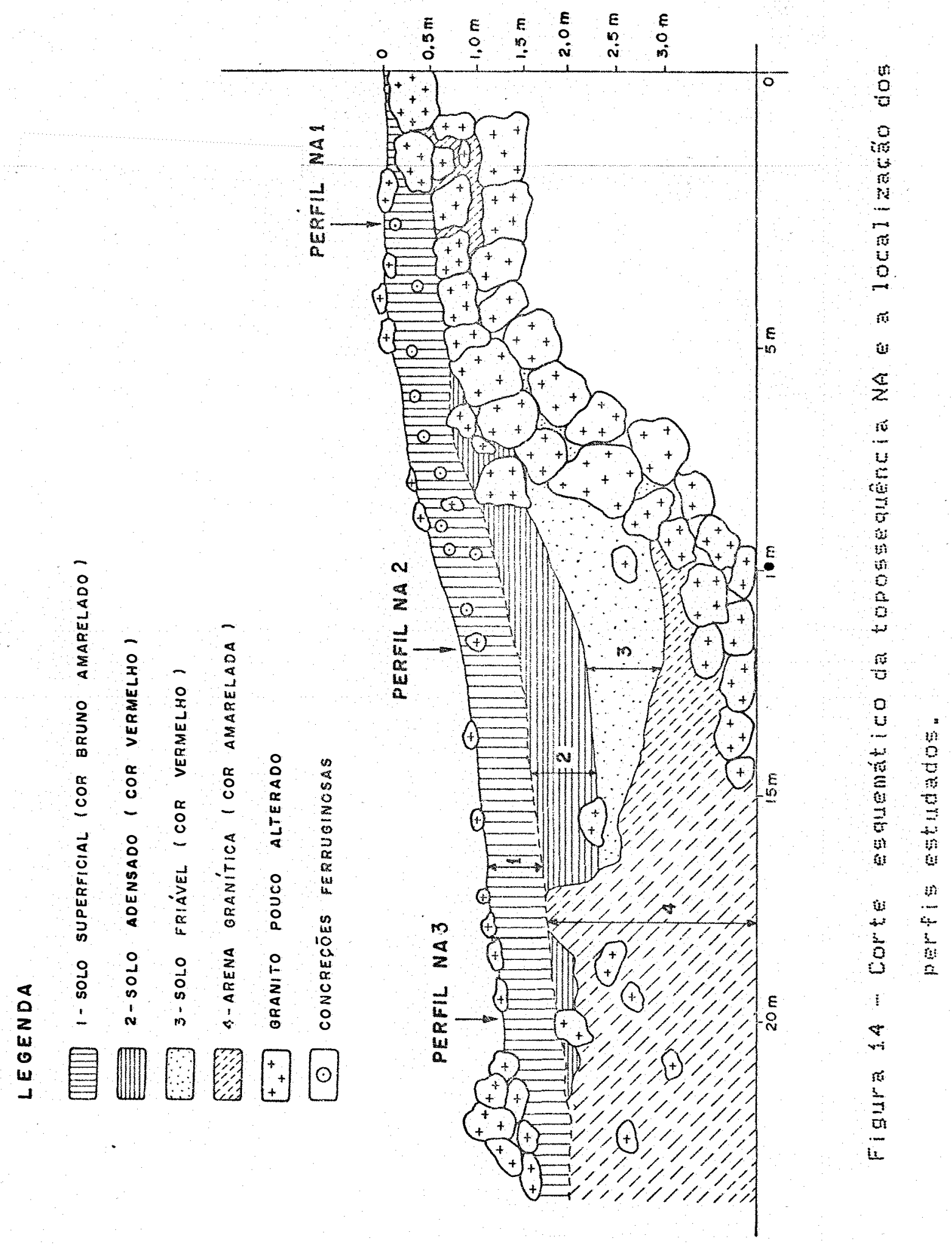


Essas duas vertentes de forma convexa, estäo localizadas numa área de relevo montantioso, com inumeros matacbes que ocorren na sua superticie e com desnivel considerável en relacäo a piso da depressäo.

A area apresonta como vegetafao dominante a Horesta ombrofila abertatropical CPROJETO RADAMBRASLL-1980) E ten seu clima caracterizado por temperatura média anual de zosoc e precipitacáo entre 2.300 e $2.400 \mathrm{~mm}$.

Todos os perfis analisados sáo constituidos por solos ben drenados, mas com profundidades que varian de 0,50 a $1,60 \mathrm{~m}$. A sequir será apresentado, 3m resumo das caracteristicas morfologicas amostradas no campo.

\section{Perfil NA1.}

Conforme se observa no corte esquenatico da topossequência NA apresentada na figura $2 A$, o perfil NAS. se localiza na parte mais elevada da topossequência e é constituido por un solo joven (solo cambissolo), de cor bruno amarelado e apresenta a rocha subjacente a $0.50 \mathrm{~cm}$ de profundidade. A sequência de seus horizontes é a seguinte: $A / B / C / R$ (Figura 15 ).

o granito subjacente a este solo encontram se pouco alterado, mas apresenta grandes fissuras que atingem a profundidade de até 1 metro. Nessas fissuras observamse materiais do granito alterado e pedologicamente 
PERFIL NAL

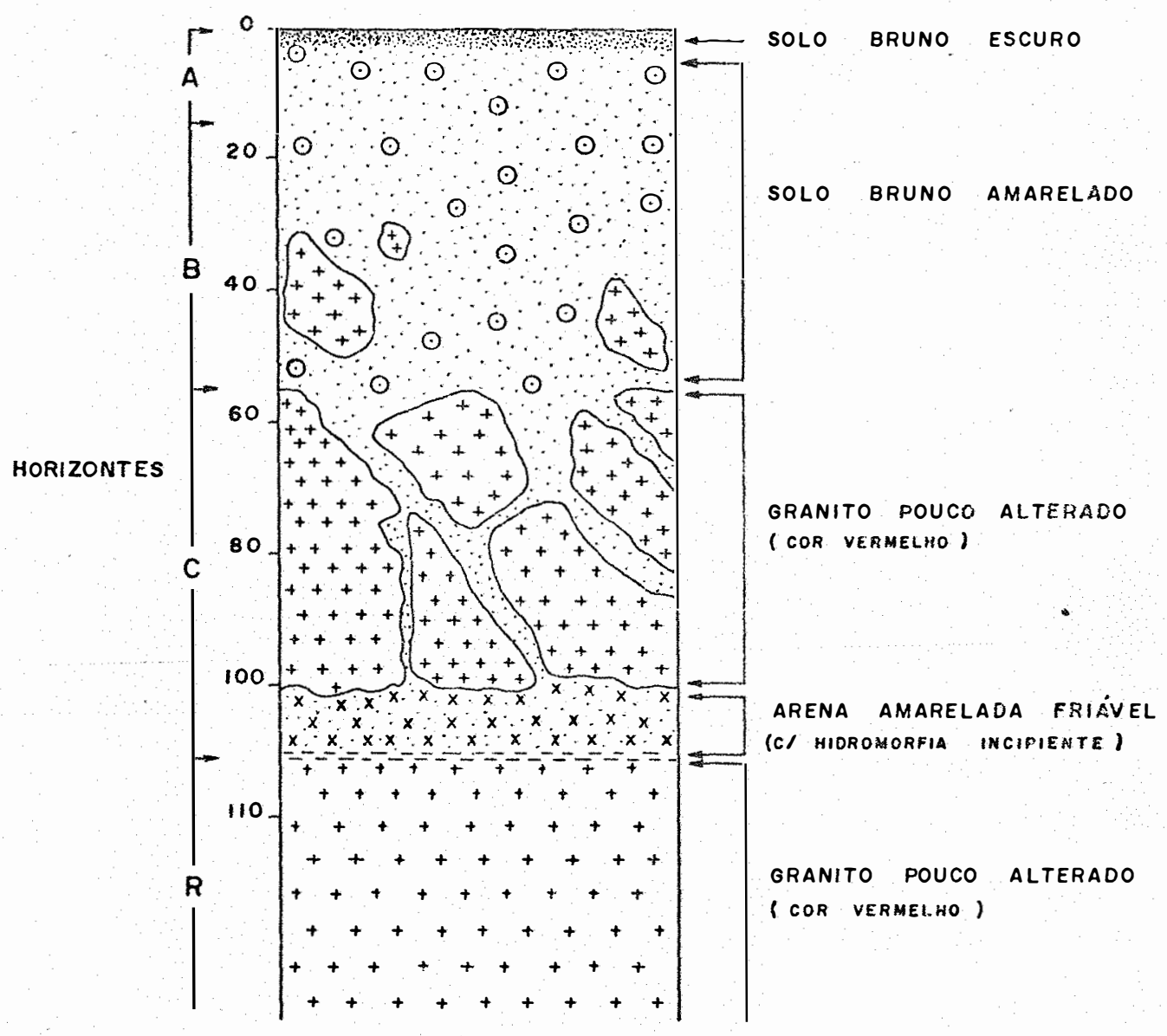

\section{LEGENDA}

\begin{tabular}{|c|c|c|c|c|c|c|c|}
\hline \%ons & SOLO & BRUNO & ESCURO & 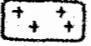 & GRANITO & POUCO & ALTERADO \\
\hline & SOLO & BRUNO & AMARELADO & $x: x$ & ARENA. & AMARELADA & \\
\hline$\odot$ & CONCF & EÇŌES & FERRUGINOSAS & & & & \\
\hline
\end{tabular}

Figura so-pertil do solo cambissolo, caracteriando como NA1 da topossequencia NA. 
bem desenvolvido, com a coloraga brona amarelada mais clara en relacäo aos solos suprajacientes.

Na profundidade de 100 a $110 \mathrm{~cm}$, observase una camada de arena amarelada bem friádel que se desenvolve numa fissura horizontal da rocha. Nesta camada, tra o indicio, ainda que incipiente, do processo de hidromorfia na sua parte basal, em funcéo da impermeabilidade da rocha e o contato com a mesma, ser abrisptico.

$$
\text { Observa-se também neste perfil NAL, }
$$
presenca de nódulos minerais ferruginizados, duro e de cor vermelho escuro e em quantidades náo muito significativas, mas cuja concentrafăo é maior na parte superior da trincheira.

\section{Perfil NAC.}

o perfil NAZ (Figura 16), constitui un solo mais evoluido, com mais de $1,70 \mathrm{n}$ de profundidade. A ciamada superficial que abrange ate $55 \mathrm{~cm}$ de profundidade, apresenta cor bruna amarelada etem a sua transicáo bastante irregular para a camada subjacente, formando "linguas" que atingen ats 90 cm de profundidade, contrastando nitidamente com o solo de cor avermelhado situado abaixo dessa camada.

Subsequentemente à camada superficial, observa-se un outro isovolume na faixa de 55 a $1.0 \mathrm{~cm}$ de profundidade que é constituido por un solo de cor 


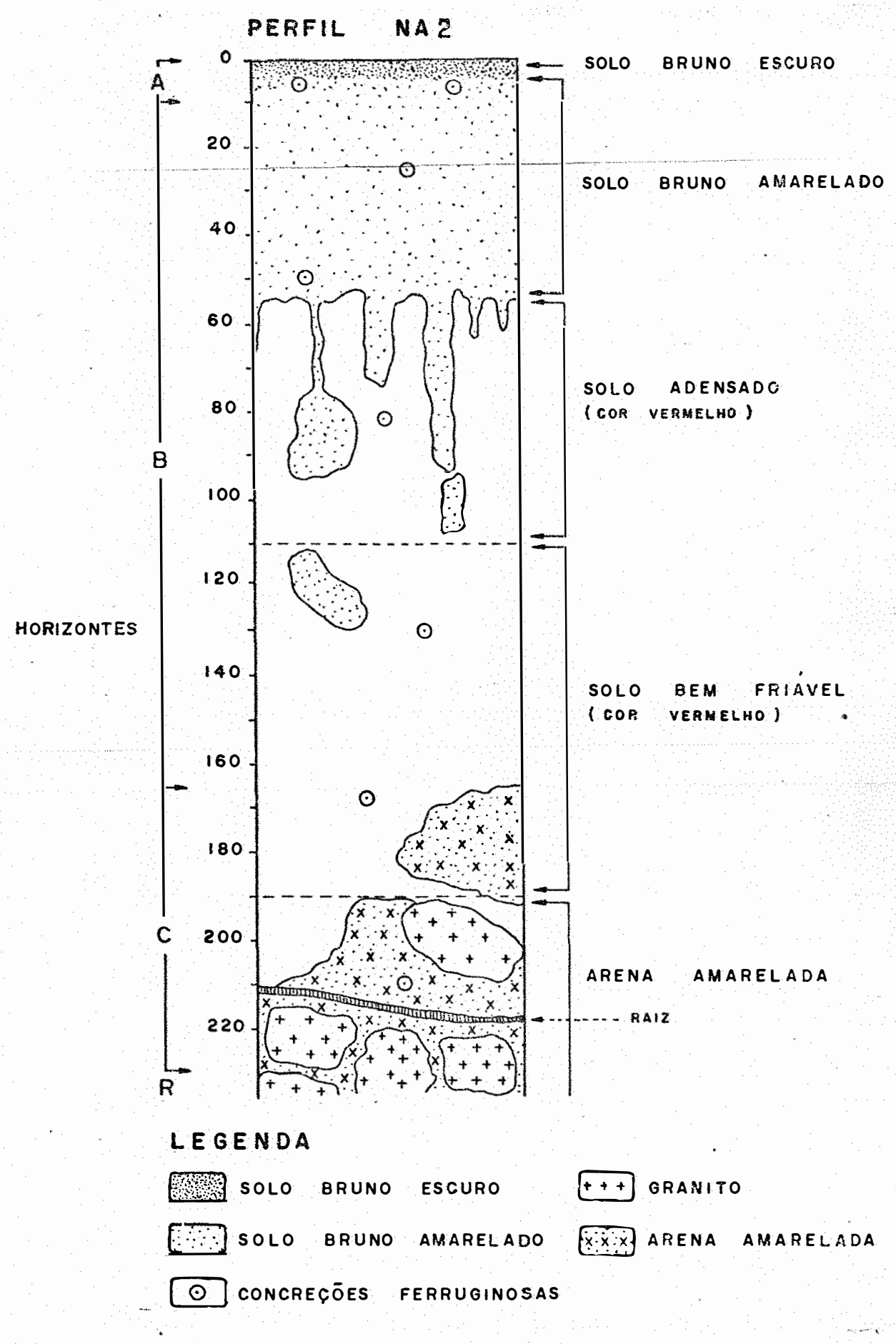

Figura fo - Perfil de solo cambissolo, caracteriando como Naz da topossequencia NA. 
avermelinada e com estrutura bastante "forte e coesa" e textura argilosan

A partir da profundidade de 1.0 a $190 \mathrm{~cm}$. observans um solo que apresenta a mesma cor vermelha do solo acima, mas comiestruturatraca, pouco foeso de de consistencia friavel. Neste mesmo isovolume observane a presenca de bolsöes constituido pela arena granitica amarelada com caracteristica de "granito podre"

Abaixo dos $190 \mathrm{~cm}$ de profundidade observase o predominio da arena granitica amaredada, caracterizada anteriormente como "granito podre" en contraste com o solo avermelhado friaved que constitui o isovolume acima. observa-se tamben a ocorrencia de blocos de granito sendo a maioria ainda intactos e alguns em alteracäo e os mesmos ja const ituem o embasamento rochoso formando desta maneira a sequencia de frorizontes do tipo $A / B / C / R$.

os nodulos minerais ferruginizados, duro e de cor vermelia escura, ocorrem neste perfid de maneira bastante esparsa e com uma concentracato um pouco mais elevada na superficie.

A estrutura bastante forte e coesa do solo na faika de 55 a $110 \mathrm{~cm}$ do perfil Nä se deve a sua textura mais argilosa e talvez influenciada pela alternancia de umedecimento e dessecacaro daste solo. 


\section{Perfil NA3.}

No pertil NA3 (Figura s.7), observa-se um solo menos evoluido, sendo gue na parte superior deste pertil, observa-se o mesmo isovolume de solo encontrado nos perfis NAs e NA2, ou seja, observacise una.camada de solo com coloracáo brunowamarelada que atinge a profundidade de $6 \mathrm{~cm}$.

Subsequentemente, na faixa de bej a 200 cm, observa se oredomínio da arena granitica amarelada com estrutura fraca e consistência friável e com disposigáo bem imbricada nos demais isovolumes encontrados nesta faima, principalmente o solo de corvermelha com estrutura fraca econsistencia friavel gue ocorre na forma de bolsas en toda a extensáo desta faixa.

A partir dos $200 \mathrm{~m}$ de profundidade, observa-se o predomínio da arena granitica amarelada mais clara com estrutura fraca e consistencia friável.

Ein toda a extensäo desse perfil, há. ocorrencia isolada deblocos de granito com diferentes estágios de decomposiano.

A ocorrencia de nódulos minerais é observada com maior frequencia na parte superior do perfil e de maneira bastante esparsa en profundidade.

Neste perfil näo toi observado a camada de solo avermelhado, com estrutura forte e coesa a exemplo do que ocorre no perfil NA2. 
PERFIL NA3

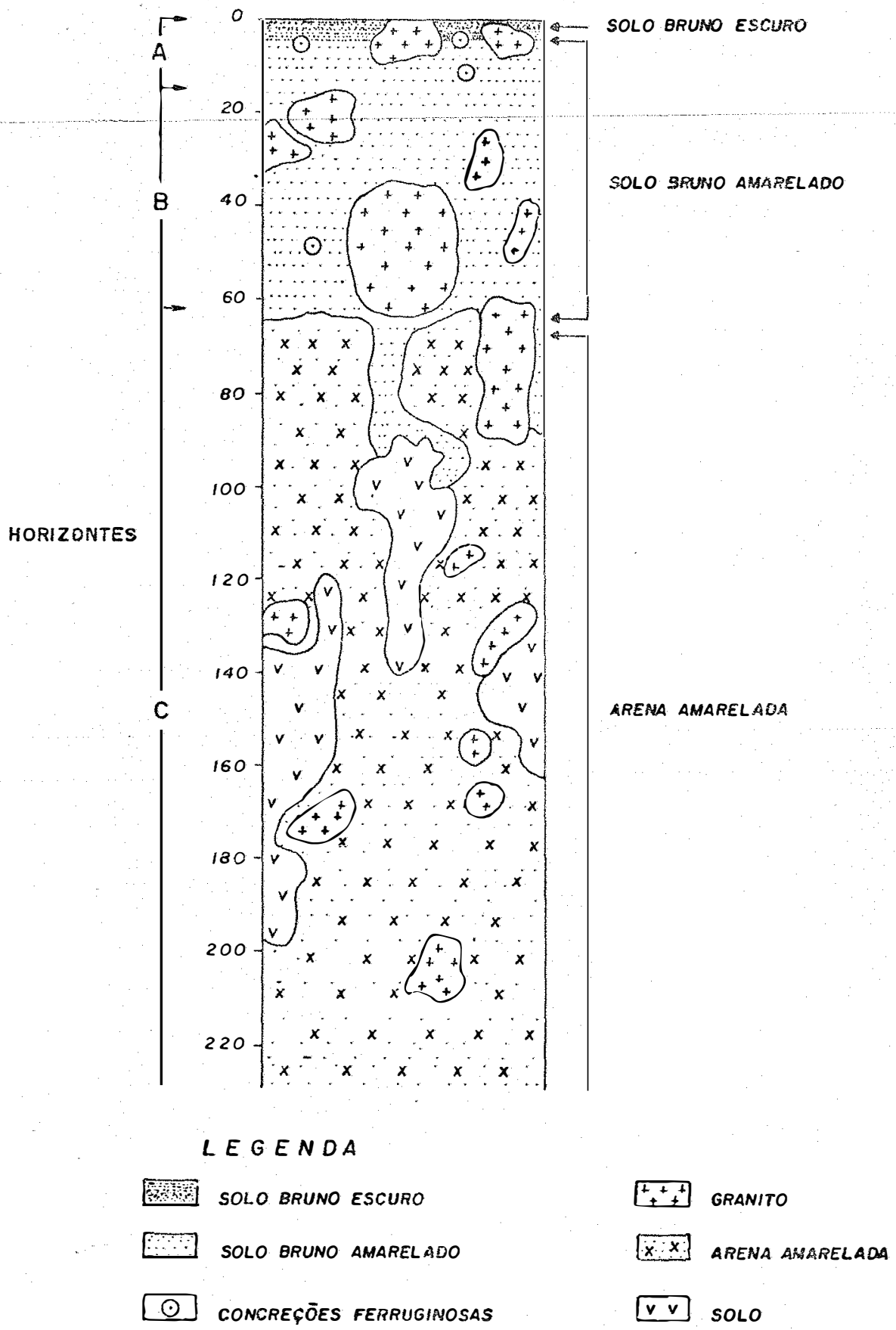

Figura sy perfia do solo cambissolo, oaracteriando como Ha3 da toposseguencia NA. 


\section{Perfil NBI}

o Pertil NBS (Figura je) também é constituido por um solo cambissolo, considerando que a camada de arena avermeltrada tipica dos granitos alterados surgem a $40 \mathrm{~cm}$ de profundidater.

A parte superior deste perfil, ou seja a camada de a po cm de profundidade, econstitulda por um solo brunomamarelado, e que tambem possui transigato bastante irregular, formando "linguas" que atingem ate cos co de profundidade. A sua coloracaro bastante contrastante com a coloracato de arena vermelha subjacente a esta camada. A faixa de 40 a $90 \mathrm{~cm}$ de profindidade, const itufda pela arena vermelha, acima mencionada.

$$
\text { Na faika de } 90 \text { a } 120 \mathrm{~cm} \text {, observa-se }
$$

predominio de um solo vermetho com estrutura pouco coesa en relacăo a arena sobreposta, mas, com textura mais $\arg$ ilosa.

\subsubsection{2-Micromorfologia.}

Como complemento ats andises morfologicas dos perfis estudados, as ankises micromorfow logicas em secoes delgadas das amostras de solos e das alteracies do granito forneceram importantes aspectos de relevancia para esta pesquisa, conformese observa nas descricóes individua is das seqöes delgadas apresentadas no Apendice 7.2 e gue säo resumidos a ses:r:

- Esqualeto: 6 abundante, ocupando cerca de 45 a $55 \%$ do volume total do fundo matricial, 


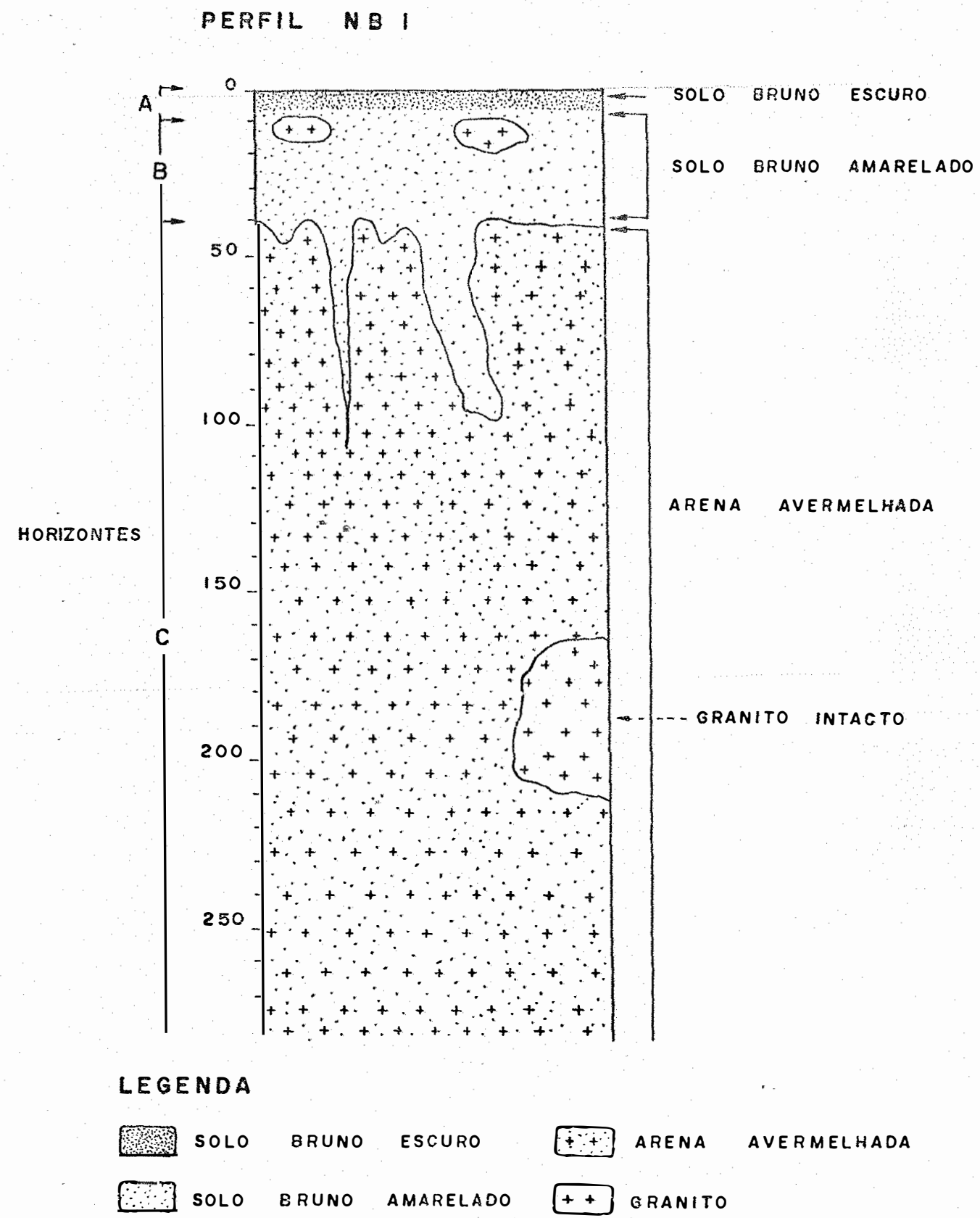

Figura 19 - pertil do 50 o ombissolo, carateriado womo NB1 da toposasenencia NB. 
$e$ é constituido quase gue essencialmente por grás de quartao $\quad(+\cdots 70 \%)$, os qua is söo normalmente angulosos, alguns bem fraturados, fissurados e impregnados com compostos de ferro de cor vermelho vivo. observa-se também fragmentos esparsos de microclina $(15 \%)$ e constituem ocasionalmente gräos complewos de minerais juntamente com quartzo ben conservado e a microclina ja em alteraciso. observanse também as palhetas de biotita $(2 \%)$ e minerais de plagioclasio ( $93 \%)$, todos esparsamente distribuidos no fundo matricial. os gráos de guartzo se apresentam angulosos quase na sia totalidade, sendo alguns na forma conchoidal. Em geral, quase a sua totalidade se apresentam intactos, sem indicio de alteracóo. Alguns se apresentam fraturados, outros ben fissurados e as vezes impregnados com bidos de ferro nas suas fissuras

Nas secires delgadas analisadas näo se observou nos minerais de quartzo o processo de arredondamento dos seus cristais, descartando qual quer possibilidade de remanejamento e transporte dos materiais detriticos que deran origen a esses solos estudados.

A presenga dos feldspatos se deve ao material de origem que é o granito reles pires. pois o mesmo apresenta elevado teor deste mineral dentre os demais que o compöem.

A microclina ocorre até nas camadas superficiais ese acentua em profundidade, principalmente nas amostras derivadas da arena granitica. 
Este mineral, ocorre de forma esparsa no solo e num estágio já de alteracáo. Constitui ocasionalmente gräos complexos de minerais juntamente com o quartzo conservado e a microclina em alteraca, mas muto ben caracterizaved com suas fraturas de borda já Herrug in izadas.

Em geral predominam-se cristais pequenos de microclina, esparsamente distribuidos no fundo matricial, além de ocorrer também alguns cristais bem desenvolvidos.

As palbetas de biotita ocorrem esparsamente distribuidas no fundo matricial e normalmente se encontram bem intemperizadas, sendo evidenciado apenas seus pseudomorfos, principalmente nas amostras de golo. Nas amostras da arena a biotita se apresenta menos intemperizacia. 0 gue se percebe normalmente é que a partir da intemperiagaro da biotita inicia-se o processo da ferruginizacádo plasma com a cor avermelhada mais ou menos transilucido.

No hor izonte A1s (b) cons do pertil Naz, náo se observa a presenga do mineral plagioclásio. Entretanto, a partir do seu horizonte Bú ja ocorrem gräos bem desenvolvidos de plasioclasios parcialmente intemperizado e com importacio de compostos de ferro nas suas fissuras.

Já no caso do pertil NA3, constata-se a presenca mesmo due esparsa, do plagioclásio en alteracáo, desde o sel hor iaonte Al $(\theta-B \mathrm{~cm})$. É bastante 
conum a ocorrência de pseudomorfos do mineral plagioclasio, en funcäo da sua quase total alteratöo.

- Matéria. orgânica: nos horizontes superticiais representa $5 \%$ do volume total do fundo matricial. Ocorre na. forma de fragmentos identificaveis como raizes en decomposigäo ou já humi ticadas, como tambén, pequenos fragmentos opacose naro identiticaveis con coloracäo marrom escura a preta.

Os agregados organomargilosos săo observados no plasma, na forma de vários grânulos mindsculos de coloracäo escura. Com un aumento de 10 a na lupa e com luz direta, esses agregados apresentam cor vermelha ben viva, que é uma das suas principais caracteristicas.

Nas amostras superficiais ocorren as vezes as pelotas fenais ("fecal pellets"), observando no seld interior inumeros agregados vermeltos formados en funcio da materia organioa em estado coloidal nun plasna de coloracăo amarelada.

- Plasma: representa $30 \%$ do volune total do fundo matricial. A cor do plasma do hor izonte Af. (x a $5 \mathrm{~cm}$ ) do perfit NAe, se apresenta com a cor 10YR. 4/6 -.. bruna - anarelada Escura, en funcäo da concentracăo da natéria ogânica coloidal. No horizonte B11 (10 a $20(\mathrm{~m})$, a sua coloracäo já se torna mais clara, passando para amarela brunada - 10YR $6 / 8$, apresentando às veaes, pontuacies avernelhadas devido à 
concentracáo de mater ia orgânica coloida complexada com a fracăo mineral do plasma. No horizonte B3 (120 a $130 \mathrm{~cm})$, o plasma apresenta coloraco amarelada - 10YR 7/8.

Na profundidade de

(B2s) do perfil NAs, verifica-se uma tendencia ainda incipiente a formaçä́ de microagregados que dispersan en alguns pontos do fundo matricial. Wa na profundidade de 75 a 85 col do mesmo perfil se observa a formacóo acentuada de microagregados com caracteristicas dos oxissolos, os quats se dispersam no fundo maxirioial. Farendo uma análise relacionada ao grau de floculacio, verifica-se que a partir da profundidade de 55 a bi coldeste perfil, os seus valores soprem um incremento abriptico de 54, s.y para 95, 2\%. Esta intensificacăo no grald de floculacáo, segundo BRADY (1979), constitui oprimeiro passo para a formagáo de agregados estáveis ou grânulos. o mesmo autor ainda afirma que a capacidade dos cations para flocular coloides do solo se acha na ordem geral a seguir: Al>Ca e Himg $+3 K^{+} N_{a}$, fato providencial pois os complexos coloidais dos solos de regiés limidas e subimidas säo dominados por alumínio. hidrogênio e cálcio.

Assim sendo, o aspecto de maior relevância observada d que à medida que se aprofunda nos perfis NA2 E NA3, as caracteristicas latossolicas tenden a se evidenciar atraves da formagáo de microagregados supra citados, os qua is tendem a se dispersar no fundo matricial alterando significativamente a morfologia dos varios. A 
estrutura plásmica é do tipo "argillasepic" com tendênoia a "skelsepic". A distribuicáo relativa do plasma e do esqueleto é do tipo "genuric".

- Vazios: representa en média $10 \%$ do volume total do fundo matricial, nas formas de transagregado, fissural, sendo dominante as rachaduras "craze planes" e obliquas "skew planes" e secundariamente as cavidades e os canais pequenos.

Nas amostras superficiais verificamse que os vazios säo constituidos por fissuras transagregados intercomunicantes nas formas obliquas ... "skew planes" e rachaduras ..- "craze planes", com domínio dos macroporos e em menor grau os mesoporos.

Em profundidades maiores, observamse que há dominância dos vazios intergranulares, bem comunicantes e grandes fissuras na forma de rachaduras "craze planes" e também as obliquas "skew planes" transagregados.

Todos esses detalhes sä́ concordantes nos demais horizontes dos perfis analisados, colocando em evidência que esses solos analisados apresentam boa drenagem, facilitando ainda a extracáo da solucăo do solo, conforme foi realiaado neste trabalho.

- Glébulas: săo representadas por concrecses ferruginosas de tamanho e forma variados. Dcorren com 1 igeiras concentracies nas porques superficiais dos perfis e säo na sua grande maioria, totalmente opacos. Alguns nódulos menores säo translúcidos, apresentando cores 
avermelhadas em lua direta. Năo foram observadas outras feigós pedoligicas como as cristalarias e os cutans.

$$
\text { A presenca de feldspatos desde }
$$

os hor izontes superficiais se deve ao pouco desenvolvimento desses solos em funcä́o do seu constante rejuvenecimento promovido pela erosáo laminar.

\subsubsection{3 - Mineralogia.}

As frabies argila e silte obtidas segundo os procedimentos descritos no item 3.4.7, for am submetidas às irradiacós de raios-x. Assim, através dos difratogramas de raios-X foram realizadas as identificafós mineralbigas, cubs resultados gấo apresentados a seguir:

Fragáo silte

A analise dos difratogramas de raios-X constantes nas figuras de no. 19 a 20 permite identificar os seguintes minerais constituintes da fracáo silte das amostras de solo e arena: caolinita, gibbsita, quartzo mica.

observa-ge que os minerais identificados säo encontrados regularmente em todos os perfis, sendo que alguns apresentam pequenas variacós quanto a area ocupada pelos picos que os caracterizam: como também, varia a intensidade dos seus picos.

A caolinita apresenta pico de 

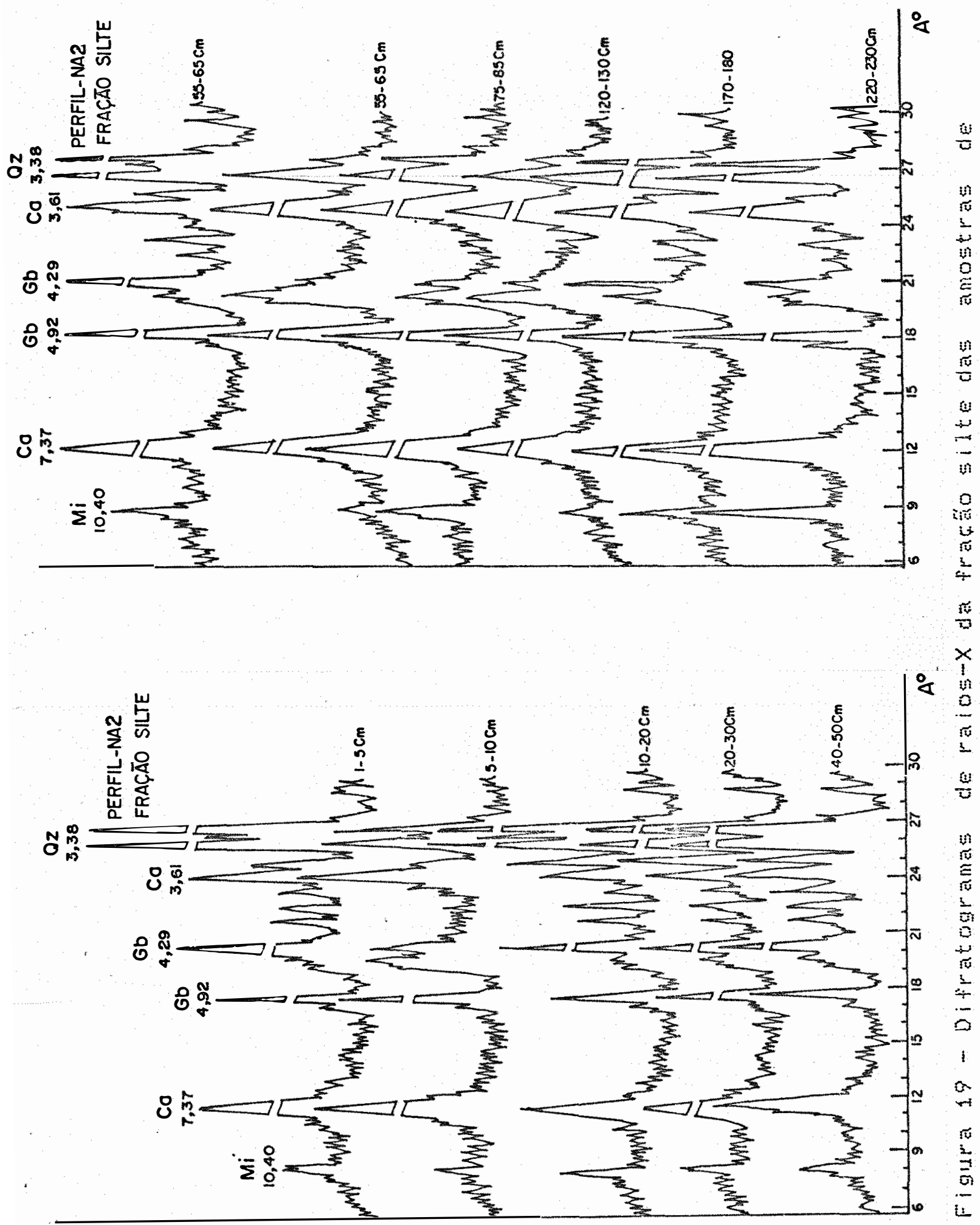

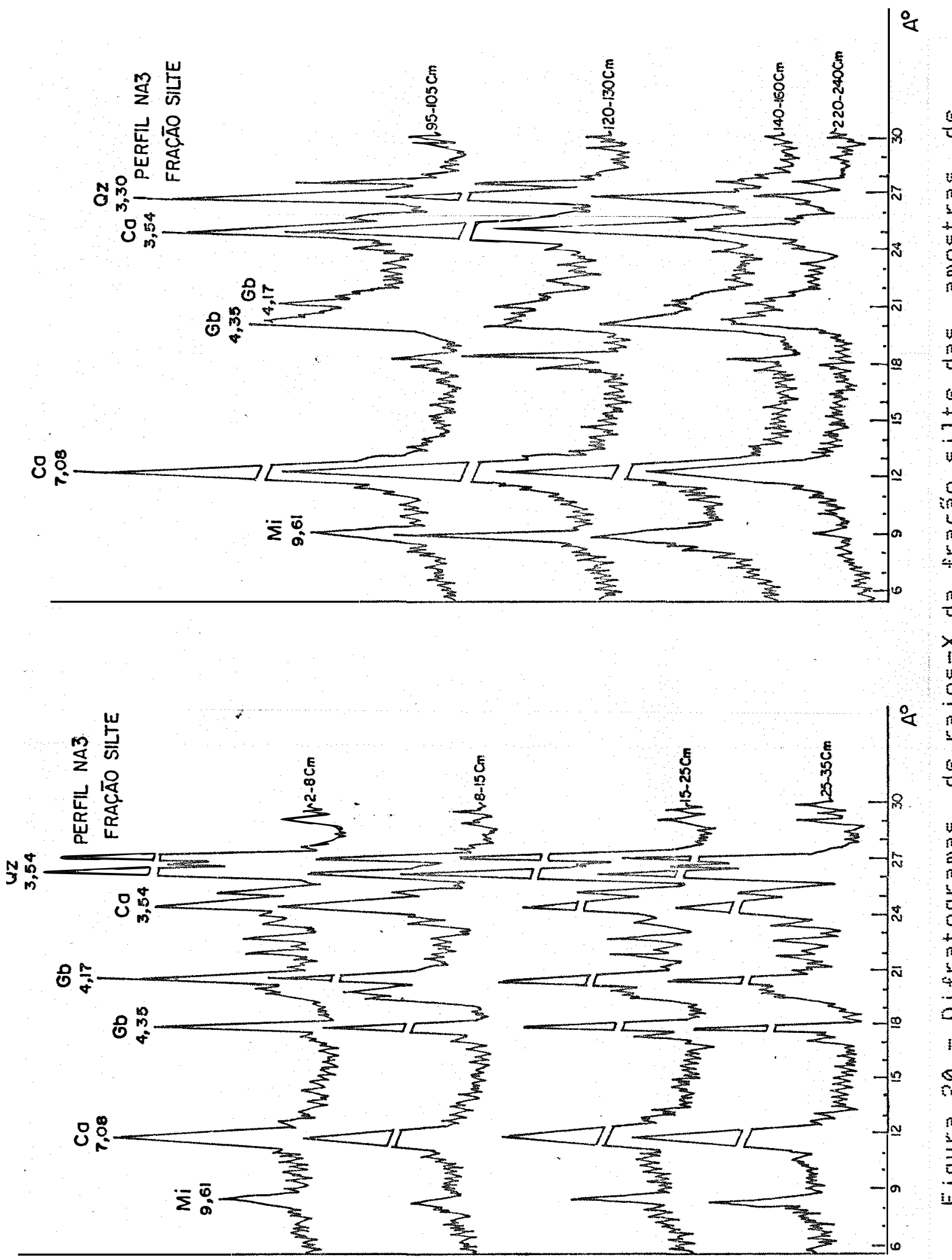


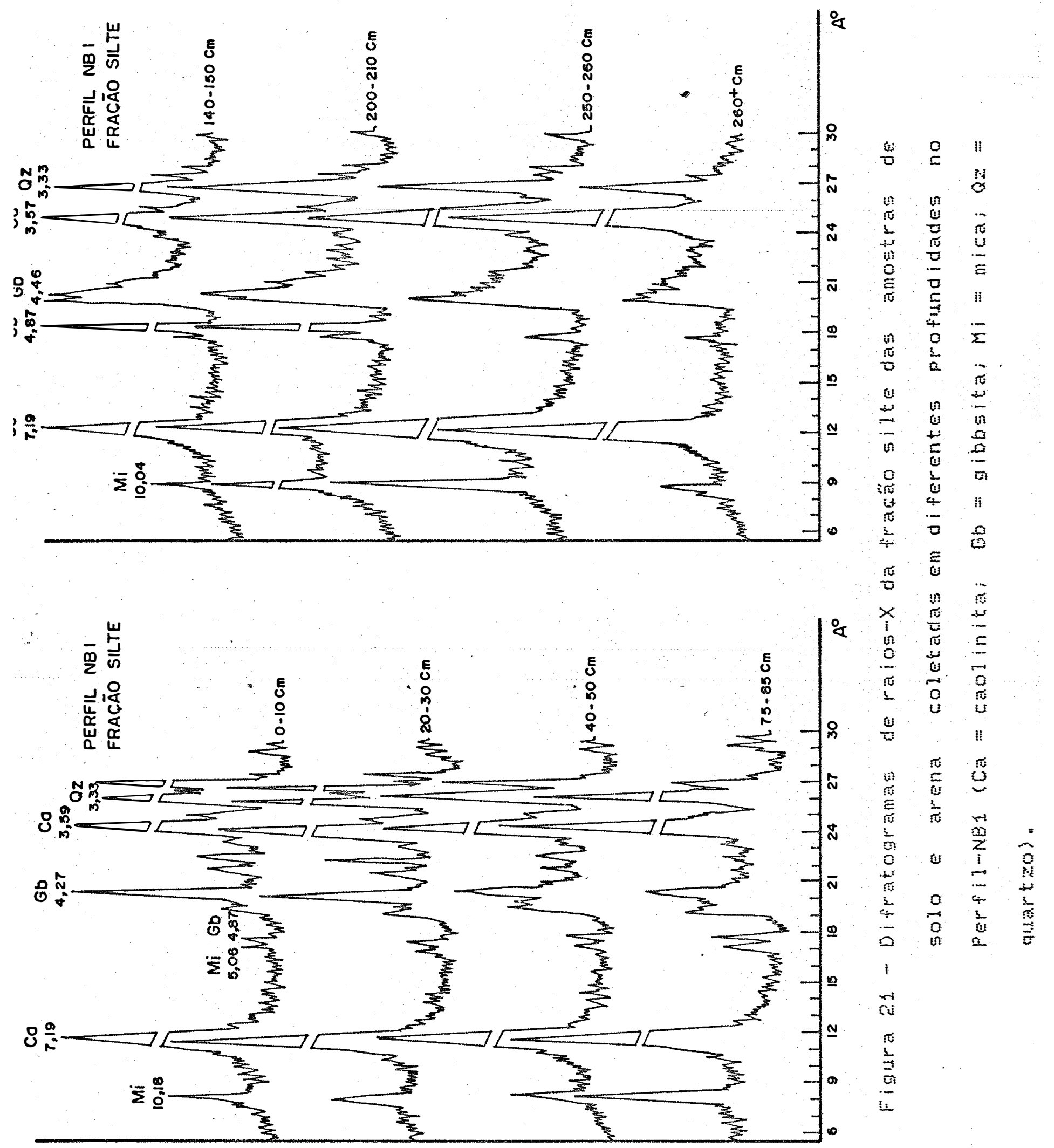



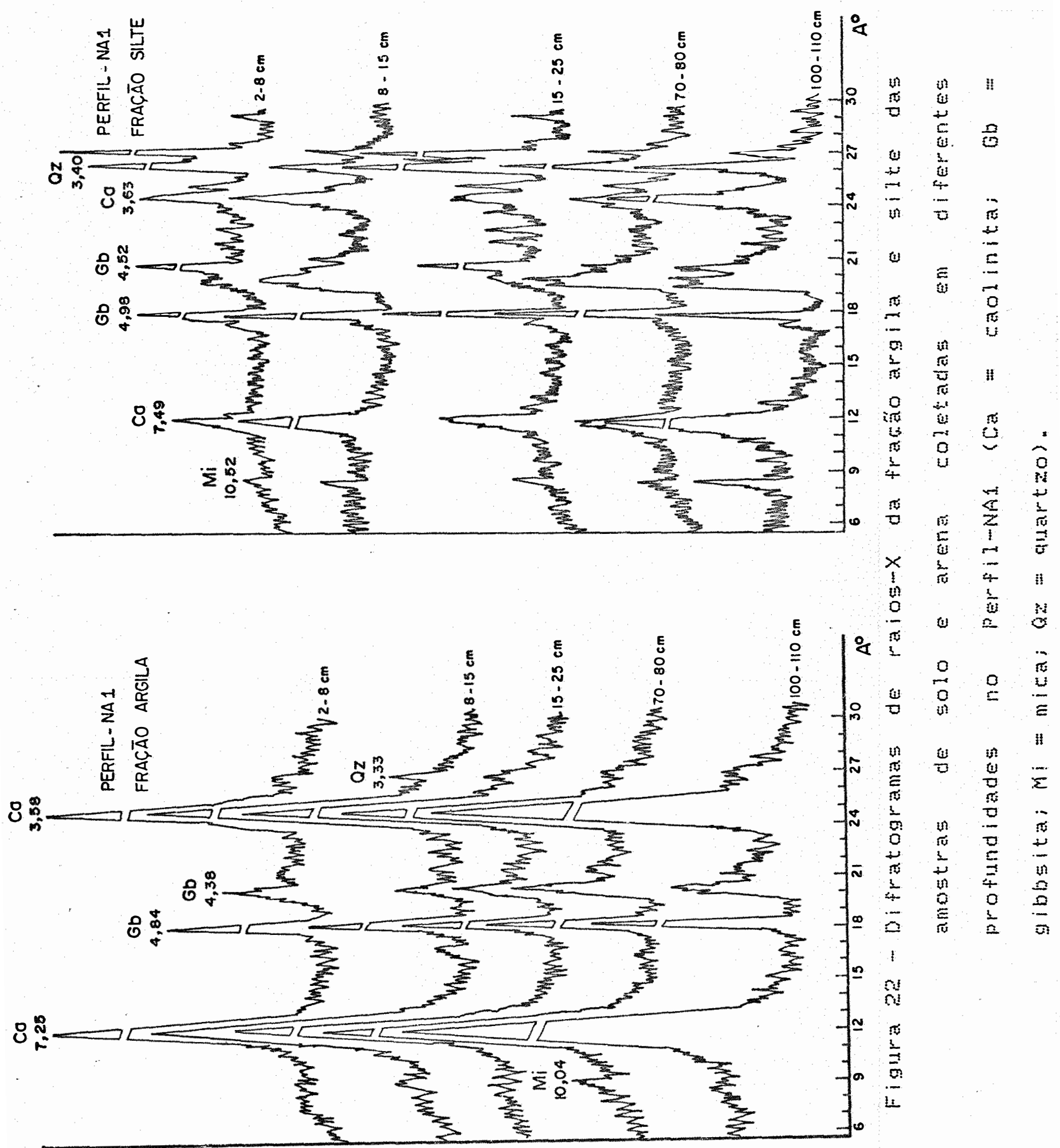
difracäo centrado nos espacamentos entre 7,19 a $7,49 \AA$ e 3,57 a 3,59 Å. Selus picos sä́ ben definidos desde as amostras dos horizontes mais profundos a Apesar da caolinita ser denotada por picos bem definidos, as amostras dos horlontes supertictats apresentam picos menos intenso en relacáo aos picos do quartzo.

Com relacäo a gibbita da fracäo silte, perceberse que suas reflexís säo ben definidas desde as amostras superficiais ate as amostras dos horizontes medianos dos pertis analisados. Seus picos estáo centrados nos espacamentos interplanares de 4,87 a $4,82 \AA$ ค $\mathrm{A}, 41$ a $4,46 \AA$.

- quartzo na fracäo silte, apresenta picos ben definidos nos espacamentos entre 3,33 a $3,35 \AA$. Nas amostras superficiais, este mineral apresenta picos mais acentuados em relacáo aos demais minerais, denotando a sua dominância. Em profundidade, ocorre uma pequena inversáo, pois a caolinita passa a apresentar picos mais acentuados vindo subordinadamente a gibbsita, o quartzo e a mica.

As reflexies da mica ocorrem entre 10,4 a $10,18 \AA$, isto porque, notranscorrer da alteracăo, as biotitas tem sua distancia interplanar aumentada de $9,81 \AA$ para $10,5 \AA$. Este aumento segundo MONIER (1977), citado por CERRI (1979) se deve à hidratagáo dos cristais da biotita.

En geral seus picos denotam 
pouca intensidade nas amostras de solo. Nas amostras da arena, percebe-se que seus picos säo mais intensos, evidenciando seu maior teor na arena. Segundo CERRI (1979), na arena onde praticamente se iniciam os processos de hidrolise, a biotita esta guase que totalmente transformada en calinita, pois a vermiculita derivada da biotita encontra caolinitat.

\section{Fracáo argila}

Através dos difratogramas de raios-X das amostras da fracáo argila constantes na figuras de no. 23 a 25, toi possivel identificar os seguintes minerais: caolinita, gibbsita, mita e martzon

A caolinita da fracáo argila é o mineral presente en todas as amostras analisadas. Os difratogranas mostran picos de alta intensidade centrados nos espacamentos interplanares entre 7,13 a $7,19 \AA$ ( 1 a. ordem) e 3,54 a $3,59 \AA$ (2a. ordem). Em funcä́o da áreà ocupada pelos seus picos, como também, pela intensidade dos seus picos, percebe-rse que a caolinita é o mineral dominante.

Com relacáo a gibbsita na fracăo argila, percebe-se que a intensidade dos seus picos nas amostras superficiais é baika, enquanto que as amostras de profundidade apresentam picos bem mais acentuados e centrados nos espacamentos interplanares de 4,82 a $4,84 \AA$ 


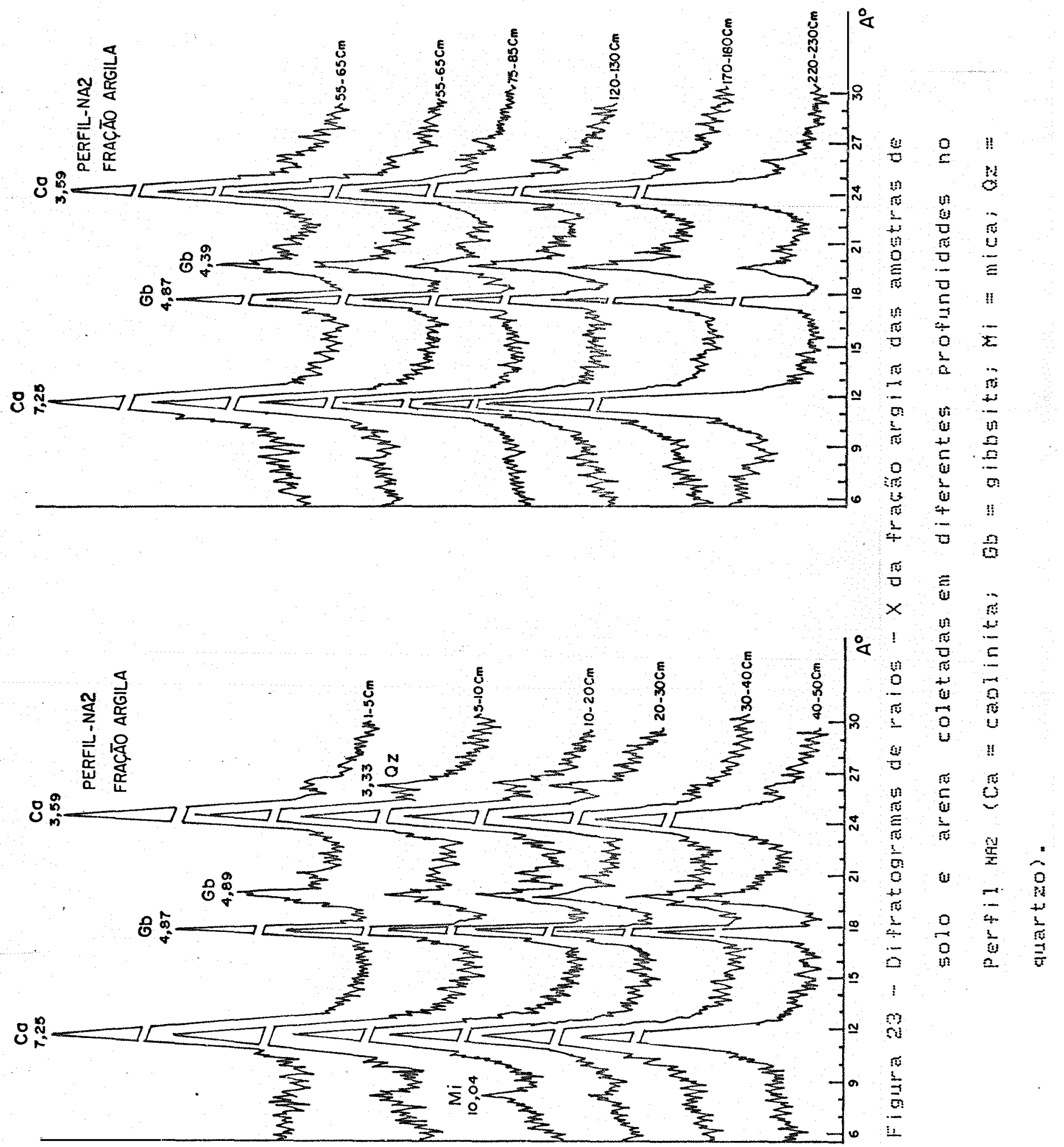



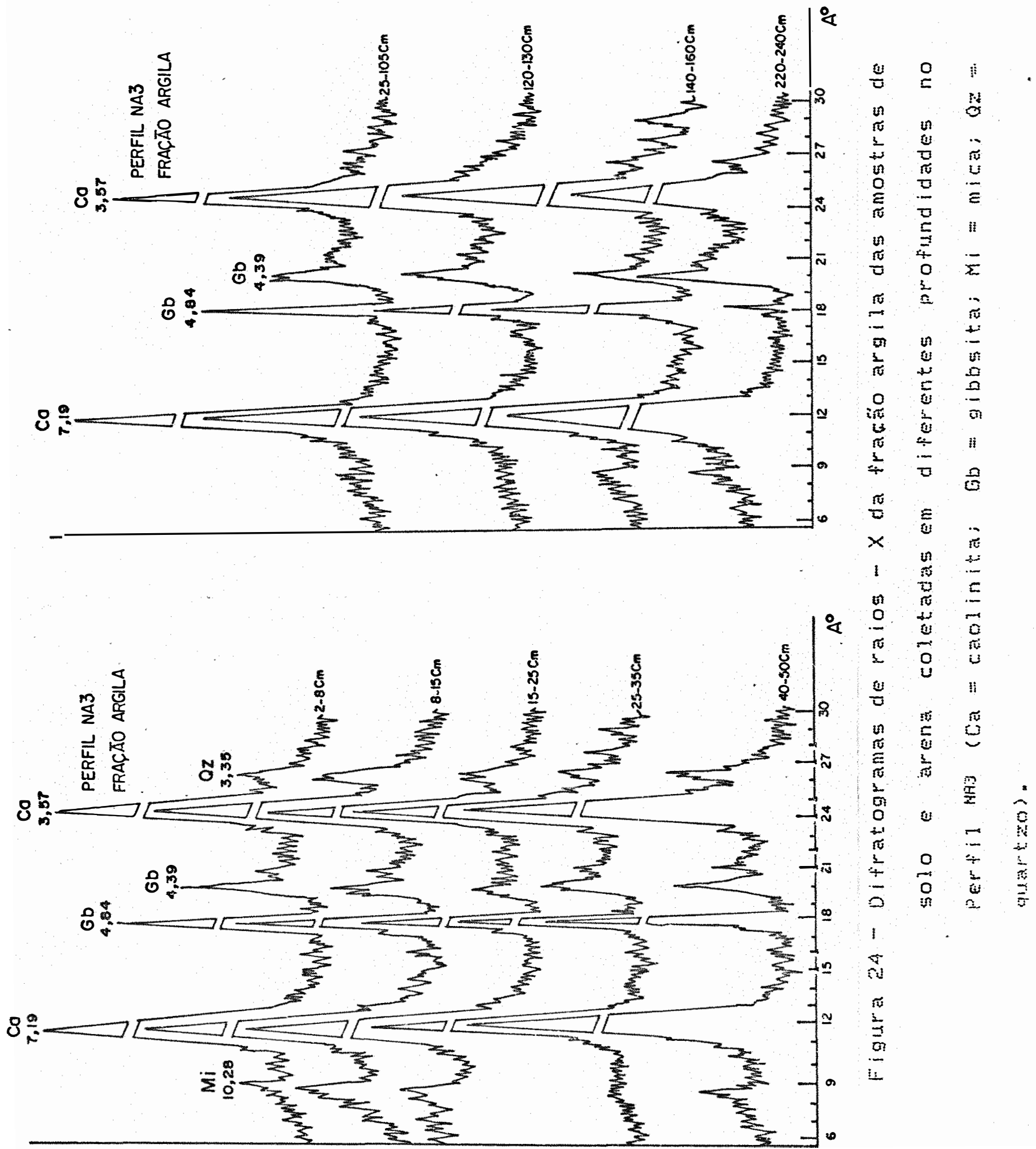


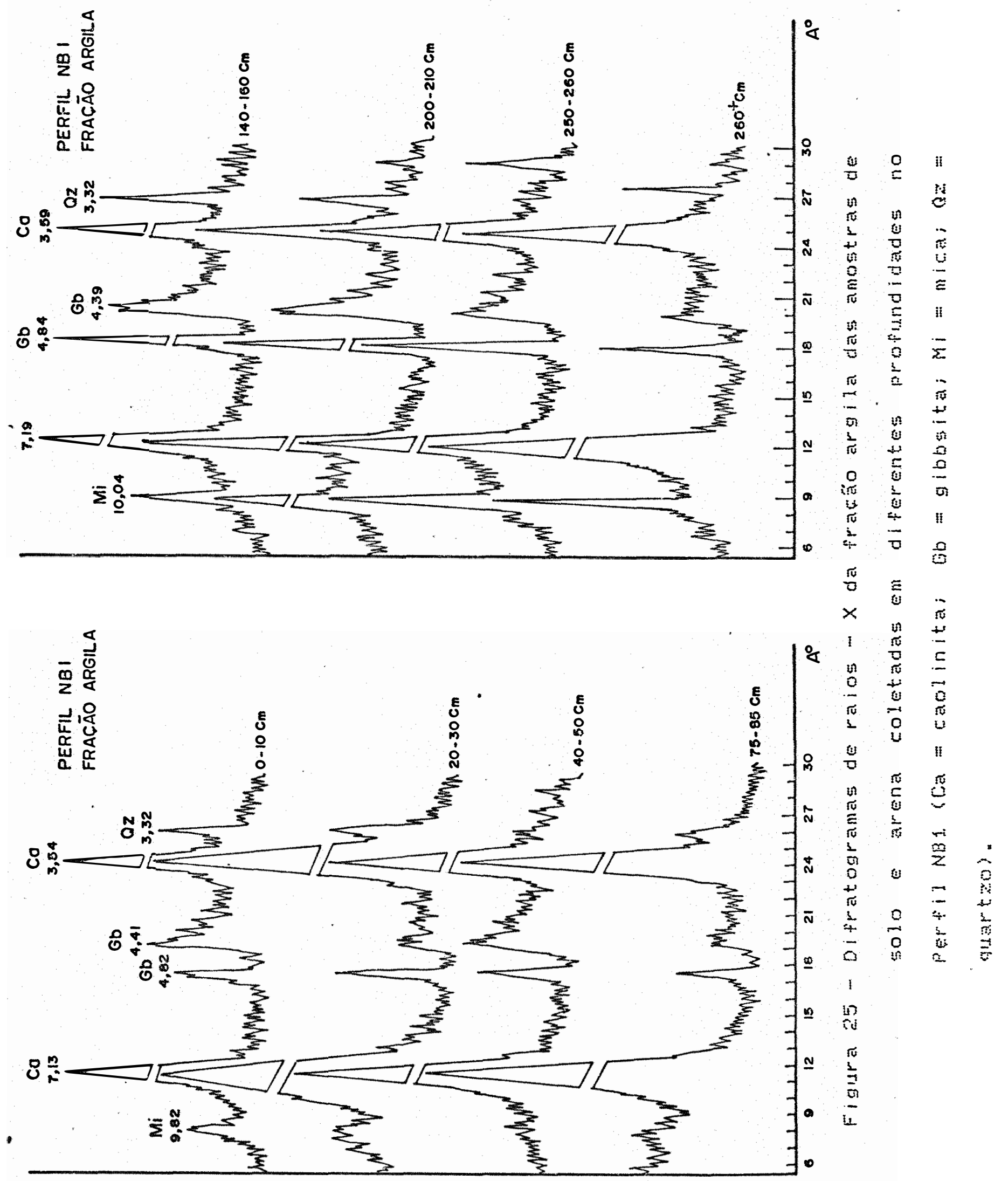


e 4,39 a $4,41 \AA$.

A mica presente na fracão argila. apresenta um aumento na sua distância interplanar de 9,82 a $10,04 \AA$, sendo portanto sua varlacäo maior em relacão às variacóes da mica da fracão silte. Percebe-se que a intensidade dos selus picos săo menores nas amostras de solo, mas nas arenas, os seus picos tendem a crescer até a profundldade observada. Isto significa que os seus teores aumentam nas amostras das arenas.

- quartzo apresenta picos definidos nos espacamentos interplanares de 3,32 a $3,33 \AA$. Os seus picos são de baika intensidade.

Qual itativamente a mineralogia dos solos dos quatro perfis näo varia, tendo sido identificadas nas suas frafóes silte e argila os seguintes minerais: caolinita, gibbsita, mica e quartzo. observa-se somente una pequena variagäo proporcional ou quantitativa dos minerais entre os quatro perfis.

A caolinita 0 argilo-mineral dominante nas duas topossequências NA $E$ NB. Este fato denota a homogeneidade bastante elevada do material de partida que é o granito Teles Pirés.

RDDRIGUES E SILUA

(1985)

estudando os cambissolos da porąa central da provincia estrutural da Mantiqueira constata que os cambissolos das partes setentrional e central desenvolvem-se "in situ" com pequena contribuifäo de material remanejado na parte 
superficial, apresenta mineralogia tipicamente gibbsitica, com uma certa proporqäo de minerais interestratificados (biotita - vermiculita Al) e caolinita de baixa cristalinidade; já nos cambissolos da parte meridional da região, constituem perfis expressos, sem reserva de minerais primários alteráveis, tipicamente caolinitico, mas que apresentam uma quantidade importante da vermiculita com Al interlamelar.

\subsubsection{4 - Caracteristicas fisicas.}

A Tabela 06 apresenta os dados referentes à fracäo maior que $2 \mathrm{~mm} e$ à distribuicão granulométrica da fracäo menor que $2 m m$ (TFSA) em termos percentuais da fracăo areia grossa, areia fina, silte, argila total e argila dispersa em água. Também, os dados referentes à relafäo silte/argila e o grau de floculacáo, densidade real, densidade aparente e porosidade de todas as amostras coletadas nos perfis NA1, NA2, NA3 e NB1 são apresentadas na mesma tabela.

Frąăo grosseira ( > $2 \mathrm{~mm}$ )

A fracäo grosse?ra representada pelos cascalihos e calbaus, corresponde a uma fracăo bastante significativa nesses solos estudados. No perfil NAl verifica-se o percentual de até $62,5 \%$ en relaço a frafáo fina (TFSA). A sua tendencia é pelo acréscimo a partir da superficie, até a profundidade mediana do perfil, seguindo por un decréscimo nas camadas mais 


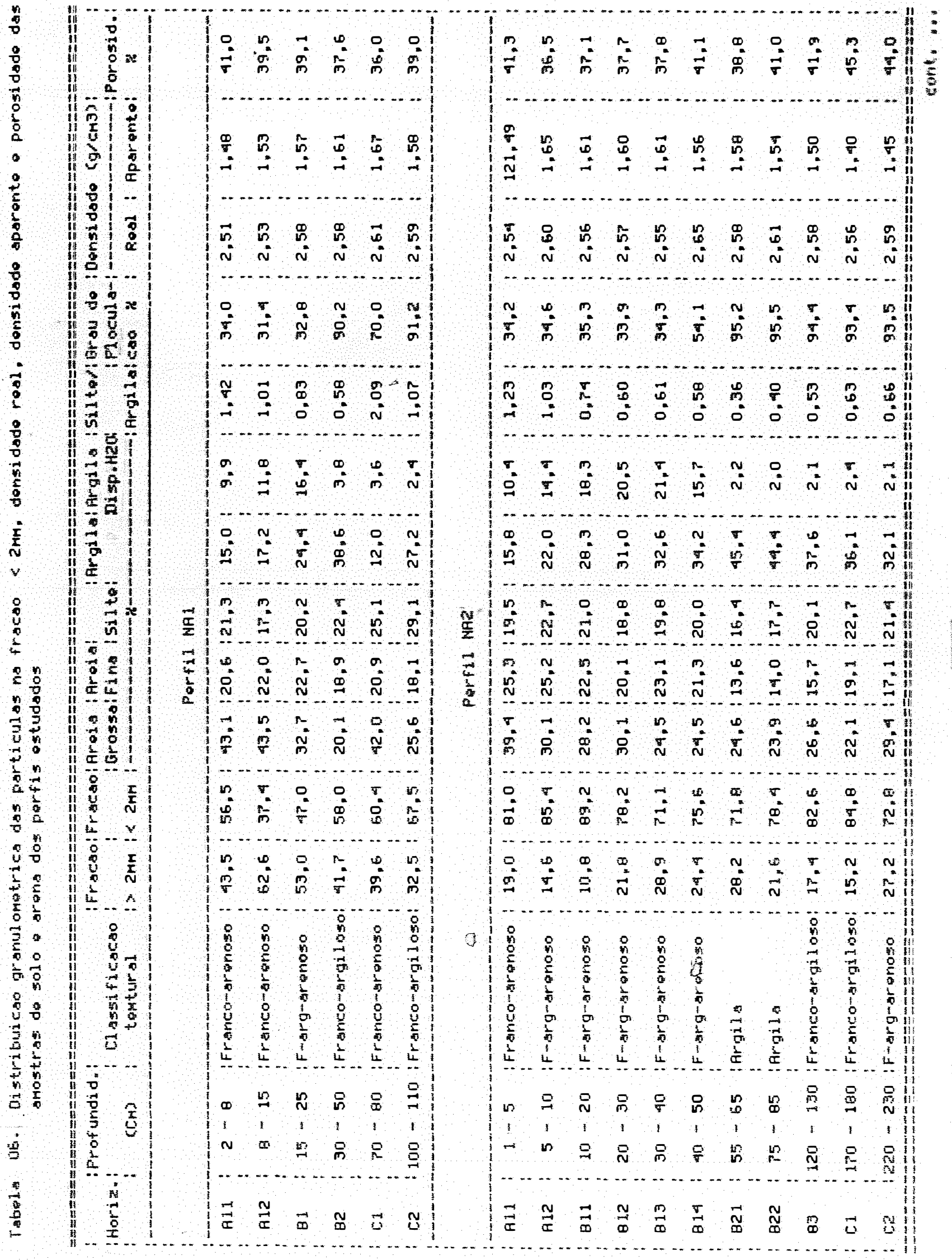




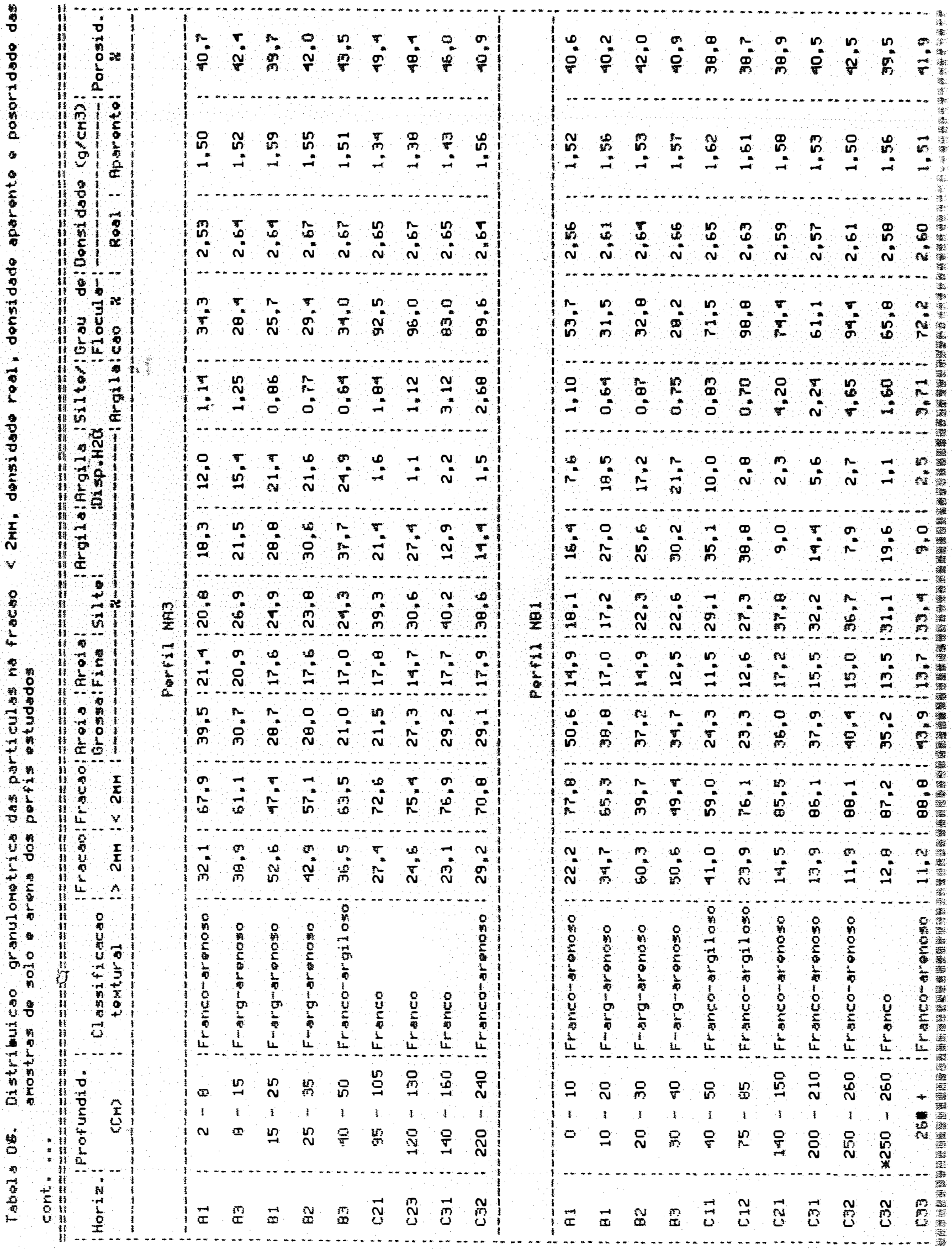


profundas. A média por perfil, apresentada a seguir, ilustra melhor a sua participacão em relacäo à fracão fina dos solos da topossequência NA:

$$
\begin{aligned}
& \text { 10.) perfil NA1 }=45,5 \% \\
& \text { 20.) perfil NA3 }=34,1 \% \\
& 30 .) \text { perfil NA2 }=20,8 \%
\end{aligned}
$$

$$
1
$$

Fracão fina (r $2 \mathrm{~mm})$

A fraço menor que $2 \mathrm{~mm}$ engloba a tracåo areia, silte, argila. A matéria orgânica presente nesta fracão foi eliminada através da oxidacão com Hade. As suas diversas frafäes granulométricas säo apresentadas na Tabela 68 .

Para melhor comparacão En relação à fracão grosseira, será apresentada a seguir os percentuais médios por perfil na ordem decrescente, da fracão menor que $2 \mathrm{~mm}$ (TFSA) na topossequência NA:

$$
\begin{aligned}
& \text { 10.) perfil NA2 }=79,2 \% \\
& \text { 20.) perfil NA3 }=65,9 \% \\
& \text { 30.) perfil NA1 }=54,5 \% \\
& \text { Este detalhe é importante, pois }
\end{aligned}
$$
a quase totalidade das propriedades fisico-quimicas do solo, reside nos argilb-minerais desta fracáo.

Areia grossa e Areia fina

Em todos os perfis analisados, observa-se que os teores de areia são bastante elevados (Figuras 26 e 27 ), atingindo valores de até $65,5 \%$ de areia (grossa f fina) no perfil NA1, na profundidade de 8 a 15 
cm. Dutro detalhe apresentado é que, os beores de areia grossa superam os teores da areia fina en todos os perfis analisados. Isto se deve às caraeteristicas do material de origem desses solos, que $\dot{e} u m$ granito de granulacáo grosseira.

É apresentada a seguir, a média por perfil, dos teores de areia grossa e areia fina dos perfis que compö́n a topossequência NA.

Areia grossa: NA1 $(34,5 \%)>\operatorname{NA} 3(28,3 \%)>\operatorname{NAZ}(27,6 \%)$
Areia fina: NA1 $(20,5 \%)>\operatorname{NA} 2(19,7 \%)>\operatorname{NA3}(18,1 \%)$

$\operatorname{sinte}$

Os teores de silte também säo bastante elevados, tendo sido observado o valor máimo de até $40,2 \%$ no perfil NA3, na profundidade de $\$ 40$ a $160 \mathrm{~cm}$.

No perfil NA1, observa-se que o selu teor cresce en profundidade, principalmente nas camadas onde há o predomínio do granito pouco alterado e da arena, observados nas camadas $70-80 \mathrm{~cm}$ e $100-110 \mathrm{~cm}$ de profundidade. Nos demais perfis, observa-se também esta. mesma tendência (Figura 28), mas a média por perfil, dos seus teores, varia da seguinte maneira:

$N A 3(29,8 \%)>N A 1(22,6 \%)>N A 2(20,0 \%)$

Argila

Com relacắ à fraç̃o argila, verifica-se que os seus teores apresentam una variabilidade multo grande (Figura 29), pois observa-se baixo teor de até 


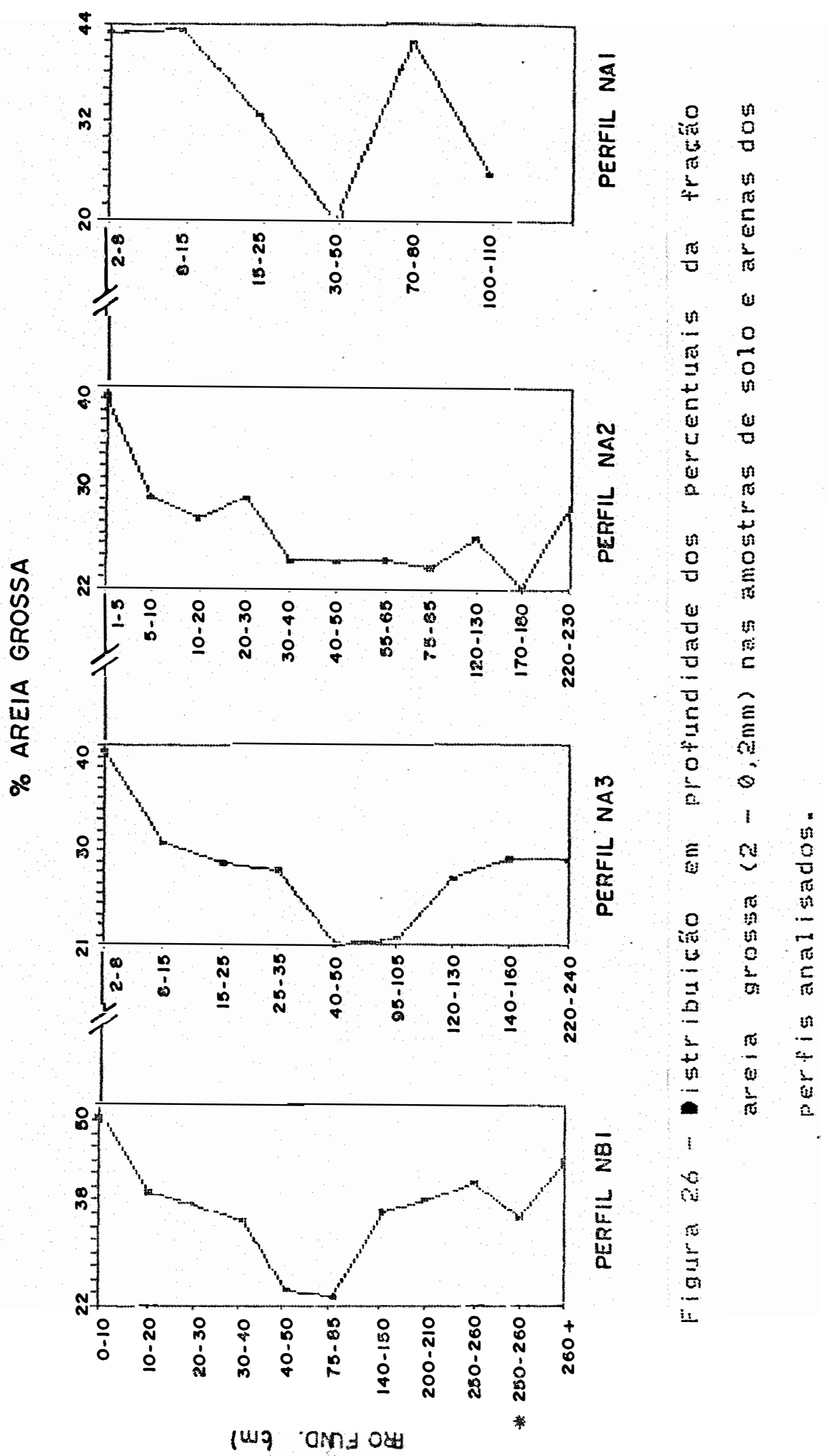




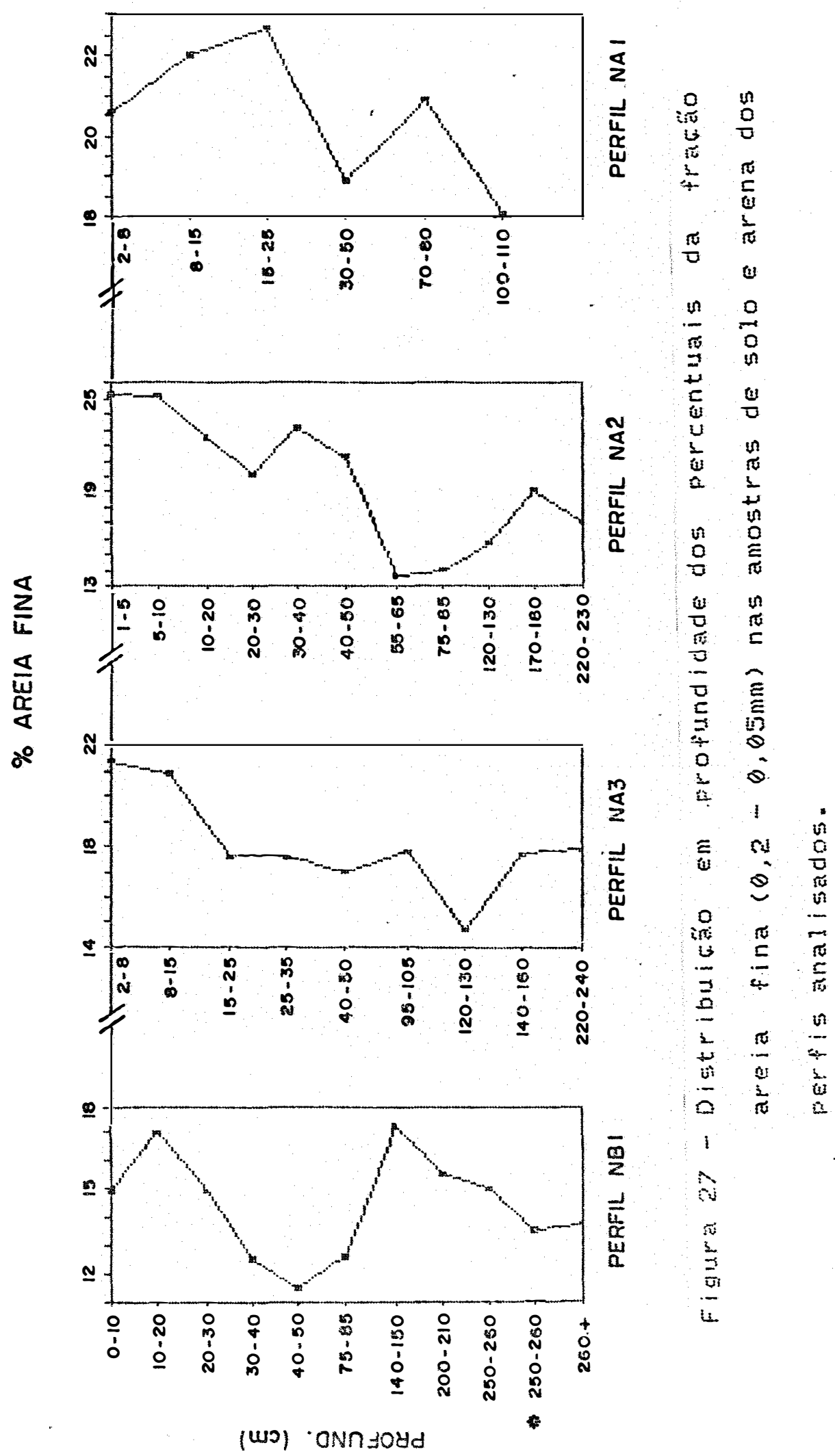




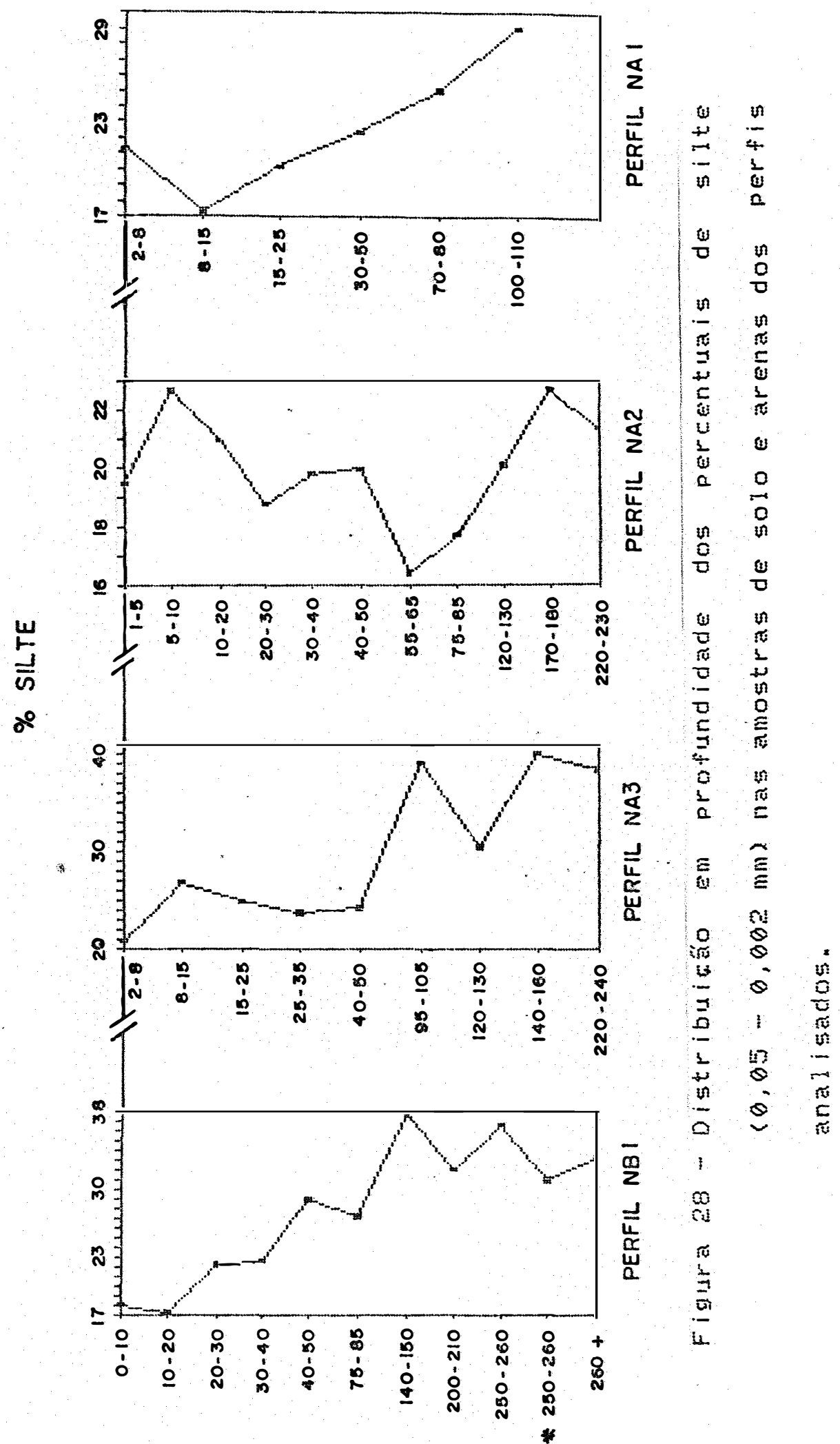

(wo) onnsoyd 
7,9\% no perfil NB1 na profundidade de $250-260 \mathrm{~cm}$, como também alto teor de até $45,4 \%$ no perfil $N A Z$ na profundidade de $55-65 \mathrm{~cm}$.

No perfil NA1, observa-se que os teores de argila crescem do valor de $15,0 \%$ no horizonte superficial para o valor de $38,6 \%$ na profundidade de $30-50 \mathrm{~cm}$. Ja em profundidade seus valores variam en funçäo da presenga da arena e do granito alterado.

No perfil NA2 também se observa esta tendência, ols seja, os seus teores de $15,8 \%$ na superficie, aumentan até a profundidade de $55-65$ cm para o teor de $45,4 \%$ decrescendo a partir dal ate a profundidade observada. Nos perfis NA3 e NB1 também se observa esta tendência.

Considerando a média por perfil, dos teores de argila desses solos na topossequência NA, constata-se a seguinte ordem decrescente do teor de argila:

$N A 2(32,7 \%)>N A 3(23,7 \%)>N A 1(22,4 \%)$

0

A partir dessas médias verificase que o teor de arbila é baixo devido ao predomínio da fraço areia principalmente na zona superficial dos perfis anal isados.

De uma maneira geral ver ifica-se que os teores de argila aumentam em profundidade, sem contudo apresentar gradiente textural que caracteriza solos com hor izonte B textural. 


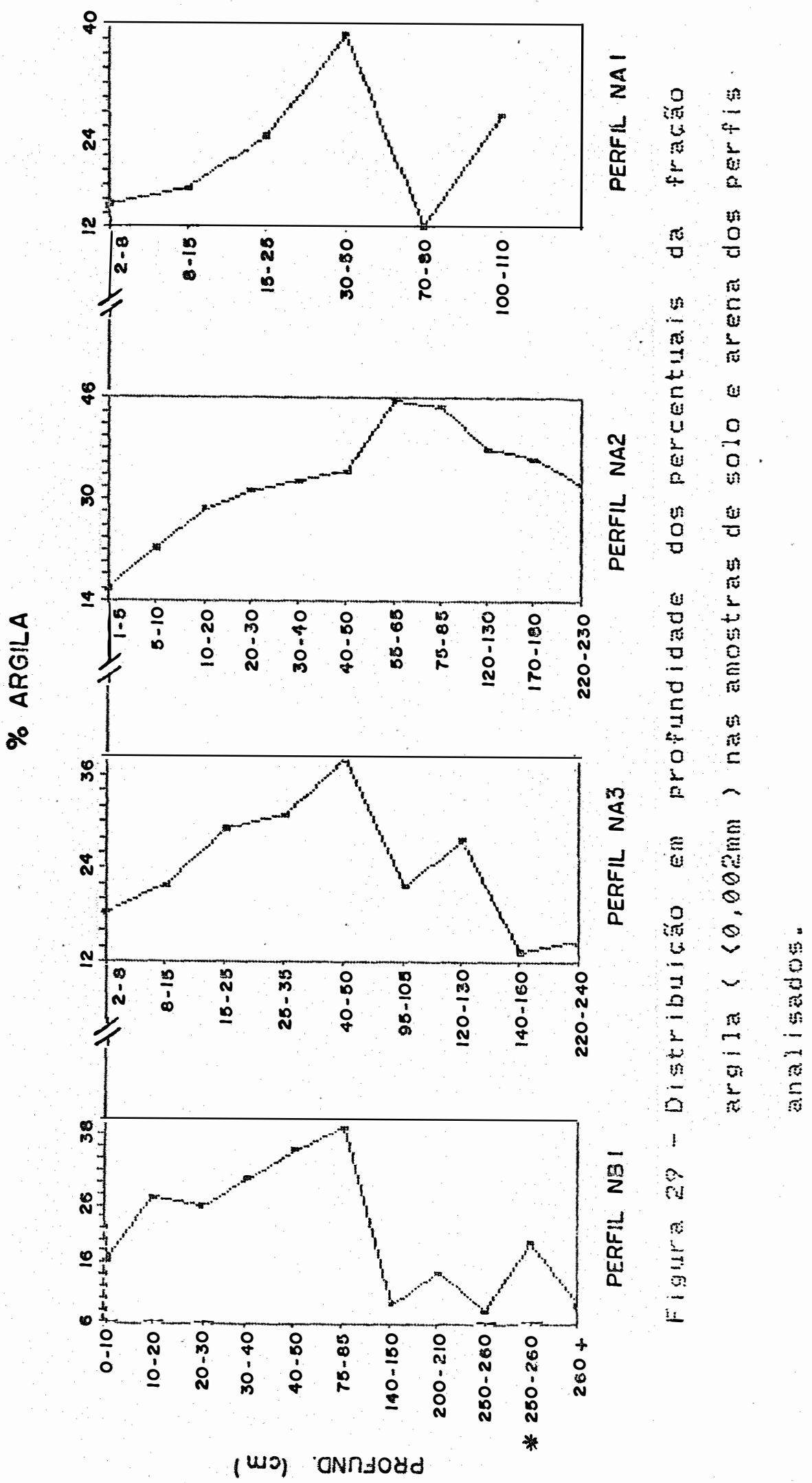


Argila natural e grau de floculafäo

A Tabela or apresenta os teores de argila natural e o graude floculacio das amostras dos perfis analisados. No perfil NA1, observawse que o teor da argila natural na superficie apresenta valor de $9,9 \%$ aumenta até a protundidade de $15-25$ cm. A partir dai, verifica-se um declínio siginificativo em profundidade para o teor de $2,4 \%$. Esta nesma tendência é observada nos demais perfis: NA2, NA3.e NBI, sendo gue no pertil NA3 e NB1, foram observados os menores teores de argila natural, at ingindo valores de $1,1 \%$.

En funcío da tendência observada para a argila natural, constata-se que ograu de flocilacto também apresenta o mesmo comportamento, ou seja, no pertil NA1, observaçe o valor de $34 \%$ na superficie, mantendomse quase constante até a profundidade de 15 -ws cm, seguindo pelo incremento significativo a partir da camada de $30-50 \mathrm{~cm}$. Esta mesma tendencia é também observada nos perfis NA2, NA3 e NBs, sendo que o perfil NBI, afresenta o valor mais elevado no grald de floculacáo, ou seja, $98,8 \%$ na camada de $75-85 \mathrm{~cm}$ de profiund idade.

Acredisame che a diferenga demasiadamente alta no grau de floculaciso dentro de cada perfil, seja atribuido à matéria orgânica na porkáo superior do perfil, e à fragáo argila coloidal nas camadas 
mats prorundas, promovendo destanara formato de mirroagregados estaveis, os ands fomancesetados atraves das analises micromorfolbotas apresentadas no iten 4.2 .1 .2$.

\section{Relatáo Silte/Argila}

A relacáo silterargila apresenta valores bastante variados en prophridade e entra os peris analisados. os valores desta relazáovariamentre o, e e 4.65

0 pertil naz hol o que apresentou a menor variacáda relacio sitalargila.

Densidade real a Densidade
aparente
Os dados referentes a densidade real e aparente săo apresentados no rabejo of e rigura 30. observa-se que a densidade real apresenta valores de 2.5 a 2.6, portanto, bastante elevada guase aquivalente bे densidade do quartzo. Náo se observa grandes var acbes nos valores da densidade real desses solos pois, os mesmos sáo ainda pouco evoluidos e sáo autbtones, serido cono mater lal de or igem, o mesmo granito reles pires.

Os dados referentes a densidade aparente, já demonstram variacbes com valores de 1,40 a 1,67. O perfil Na1 apresenta o valot de 1,48 de densidade aparente na superficio e. a tendencia é un aumento gradativo en profundidade, principalmente nas camadas onde 


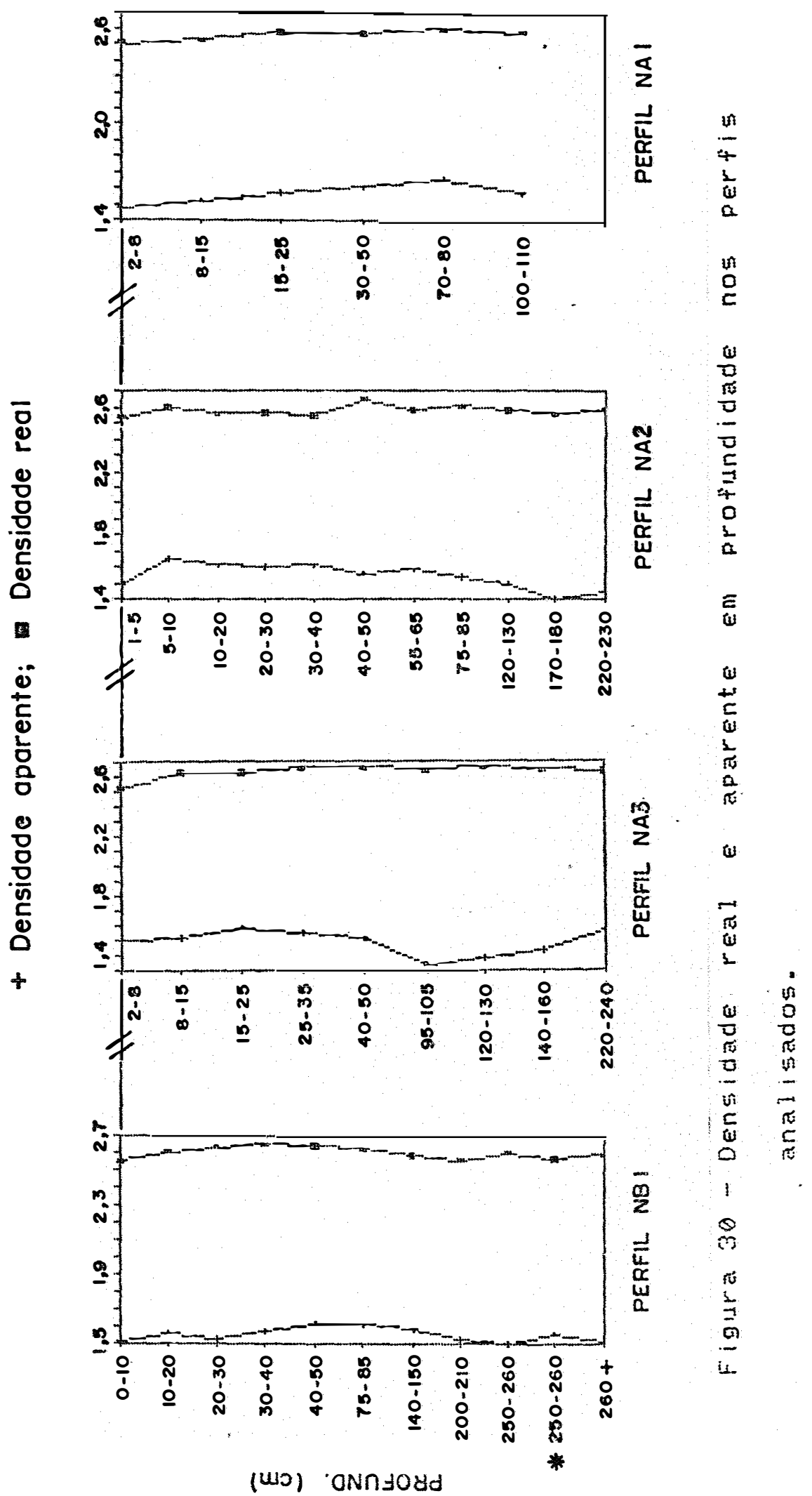


ocorre a arena e granito pouco alterado.

No perfil NA2, ocorre una

tendência inversa en relacáo ao perfil Naí, pois há un decréscimo gradativo en profundidade, ou seja nas canadas onde ha predominio da arena granitica anarelada. No perfil NA3 tambén se observa a mesna tendência até a profundidade de 95-105 cme a partir dai, verifica-se un leve incremento até sua base.

- perfil NB1 apresenta una homogeneidade mito grande com relafáo à densidade aparente, e o seu valor médio que é de 1,55 pouco difere da nédia do perfil NA1 que é de 1,57.

Considerando a média por perfil, dos valores da densidade real e densidade aparente das amostras dos perfis da topossequencia $N A$, é a seguinte na sua orden decrescente:

$$
\begin{aligned}
& \text { D.a }=\operatorname{NA1}(1,57)>\operatorname{NA3}(1,48)>\operatorname{NA2}(1,41) \\
& 0 . r=\operatorname{NA3}(2,64)>\operatorname{NA2}(2,58)>\operatorname{NA1}(2,56)
\end{aligned}
$$

\section{Porosidade}

A porosidade determinada pelo método indireto apresenta valores que varian entre $36 \%$ e 49,4\%. O pertil NA1 apresenta maior porosidade ra. sua superficie (Figura 31 ), declinando en profundidade até a camada de $70-80 \mathrm{~cm}$, nas na camada de $100-110 \mathrm{~cm}$, observa-se un leve aumento da sua porosidade, tendo en vista a diferenca significativa do seu teor de argila en relacăo à canada superficial. 


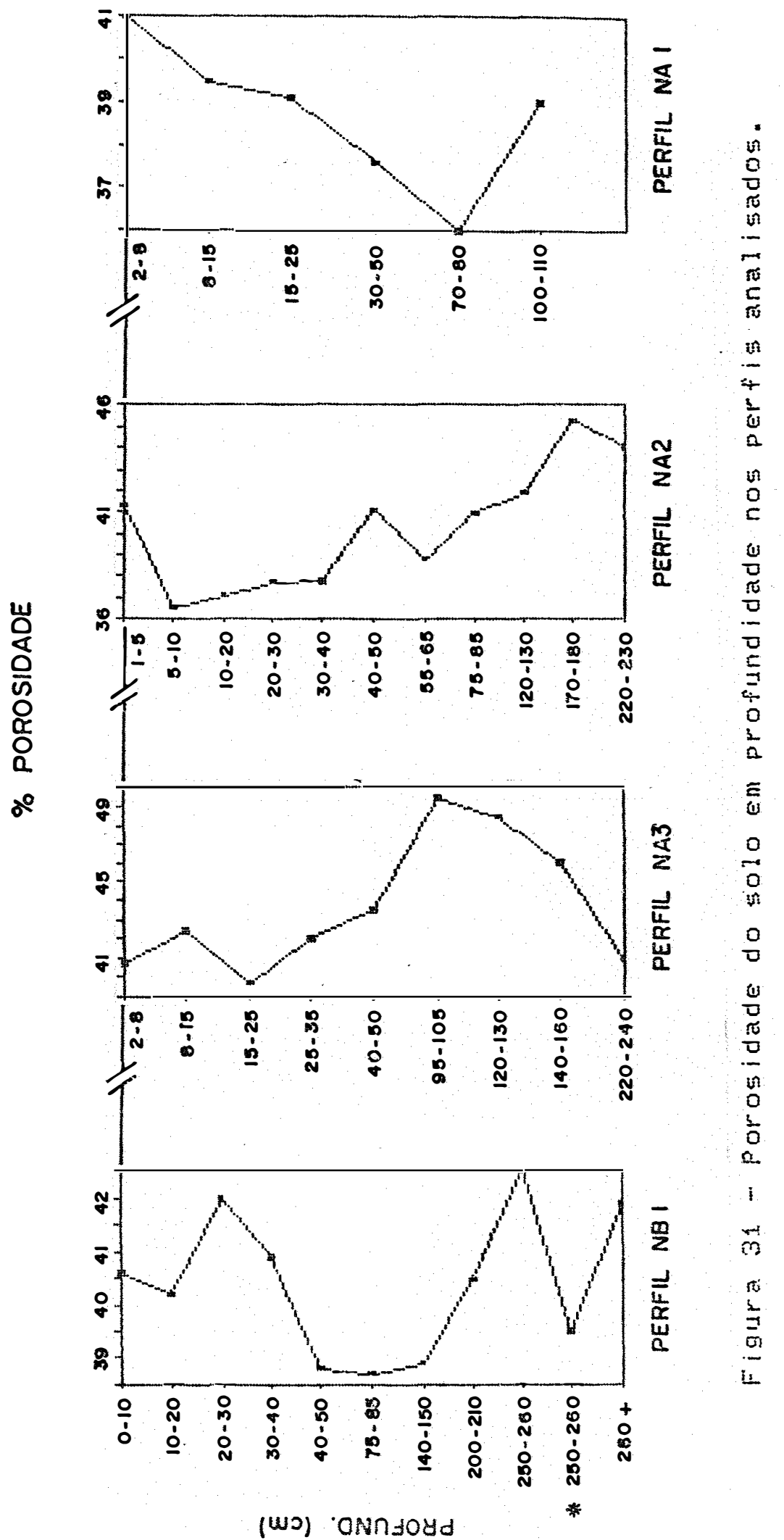


No perfil NA2, observa-se una porosidade de $41,3 \%$ na camada superticial, decrescendo até a profundidade de $30-40 \mathrm{~cm}$. A partir dai, verifica-se o acréscimo da porosidade principalmente nas camadas onde há o predominio da arena granitica amarelada que se apresenta mais friável e menos compacta.

No perfil NA3, observa-se o incremento da sua porosidade em profundidade. Neste perfil observa-se a porosidade de $49,4 \%$, o qual foi a maior porosidade verificada en relacáo aos demais perfis. Este fato pode ser explicado pela presenca predominante da arena granitica amarelada a partir de 50 cm de profundidade.

No perfil NB1, verifica--se que a porosidade varioly mito pouco. Os seus menores valores se concentram na faixa de 40 a $150 \mathrm{~cm}$ de profundidade.

Considerando a média por perfil, dos valores da porosidade desses solos amostrados na topossequência NA, constata-se que a orden decrescente da porosidade dos perfis é a seguinte:

NA3 $(43,7 \%)>N A 2(40,1 \%)>N A 1(38,7 \%)$

4.2.1.5 - Caracteristicas quimicas.

Neste item serä́o discutidos os resultados analiticos das amostras de solo e arena, constantes na Tabela 07 e apresentados através das figuras de no. 32 a 37 , no que se refere aos teores de cations 
básicos trocaveis, soma debases, teores de $H^{+}$e ${ }^{+3}{ }^{+3}$, capacidade de troca catiônica, indices de saturacä́o de bases, valores de $\mathrm{pH}(\mathrm{H} 2 \mathrm{O}), \mathrm{PH}(\mathrm{KCl}), \triangle \mathrm{pH} \mathrm{e}$ indices de saturacáo de alumínio, e teores de fósforo.

Com relacäo aos resultados dos teores de carbono, nitrogênio e a relacäo $C / N$, os mesmos já foram apresentados e devidamente discutidos no item 4.1.2.1, juntamente com os dados obtidos com o fracionamento granulométrico da matéria orgânica e dados amostrados da liteira.

Antes da discussäo dos resultados obtidos, é importante observar, que todos os perfis analisados se encontram sob floresta submontana com cipós (PROJETO RADAMBRASIL - 1980), ainda intacta, conforme foi caracterizada no iten 3.1 .3 e descrita con mais detalhes no iten $4.1 .2 \mathrm{em}$ funcäo das observacies realizadas no local desta pesquisa. pode-se afirmar portanto, que os dados obtidos näo sofreran influências antrópicas, as quais poderiam descaracteriza-los e induzir desvios nas suas interpretacífes.

Dutro detalhe importante, é que os teores do complexo sortivo serä́ discutidos em termos de "mea/joog de terra fina seca ao ar", ou simplesmente "meq/108g", independente da amostra ser constituida pelo solo prepriamente dito, ou pela arena granitica commente encontrada nos pertis analisados. 


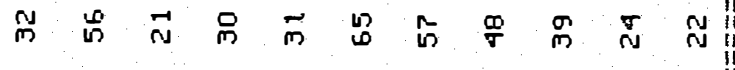

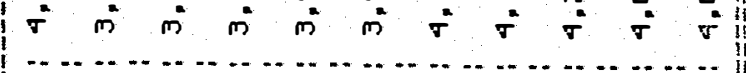

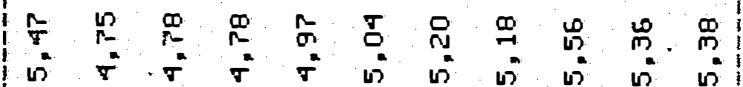

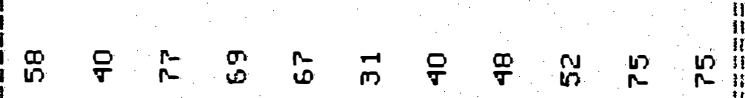

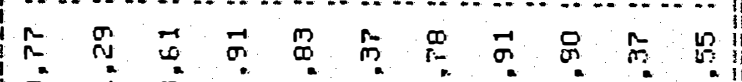

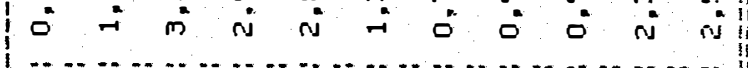

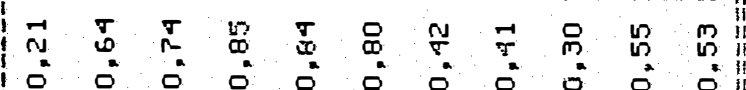
$\exists$ a 9 b

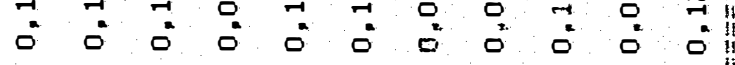

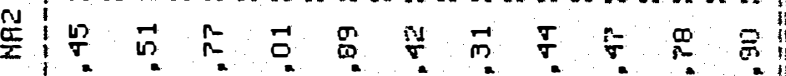

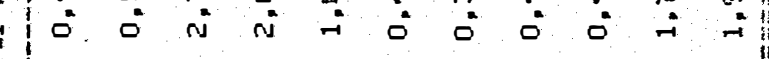

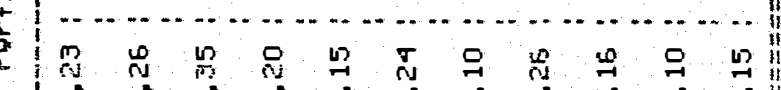
0

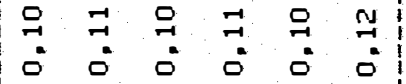
(1..................... $\left|\begin{array}{llllll|}M & T & M & m & 5 & m \\ 0 & 0 & 0 & 0 & 0 & 0 \\ 0 & 0 & 0 & 0 & 0 & 0\end{array}\right|$

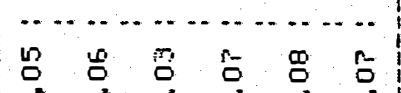

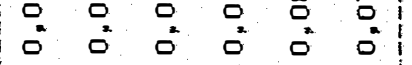
$0^{\circ} 0^{\circ}=0^{\circ} 0^{\circ} 0^{\circ} 0^{\circ} 0^{\circ}$

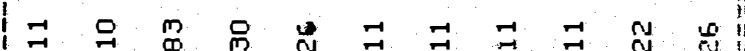

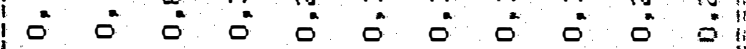
- 110 :

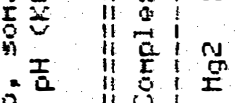

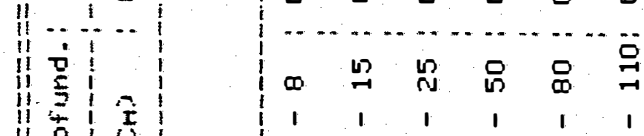
$\therefore$ No@品品

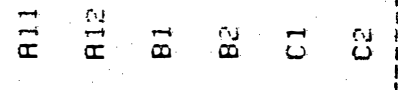

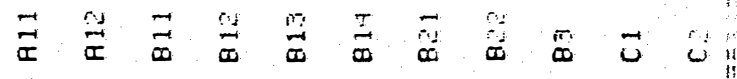




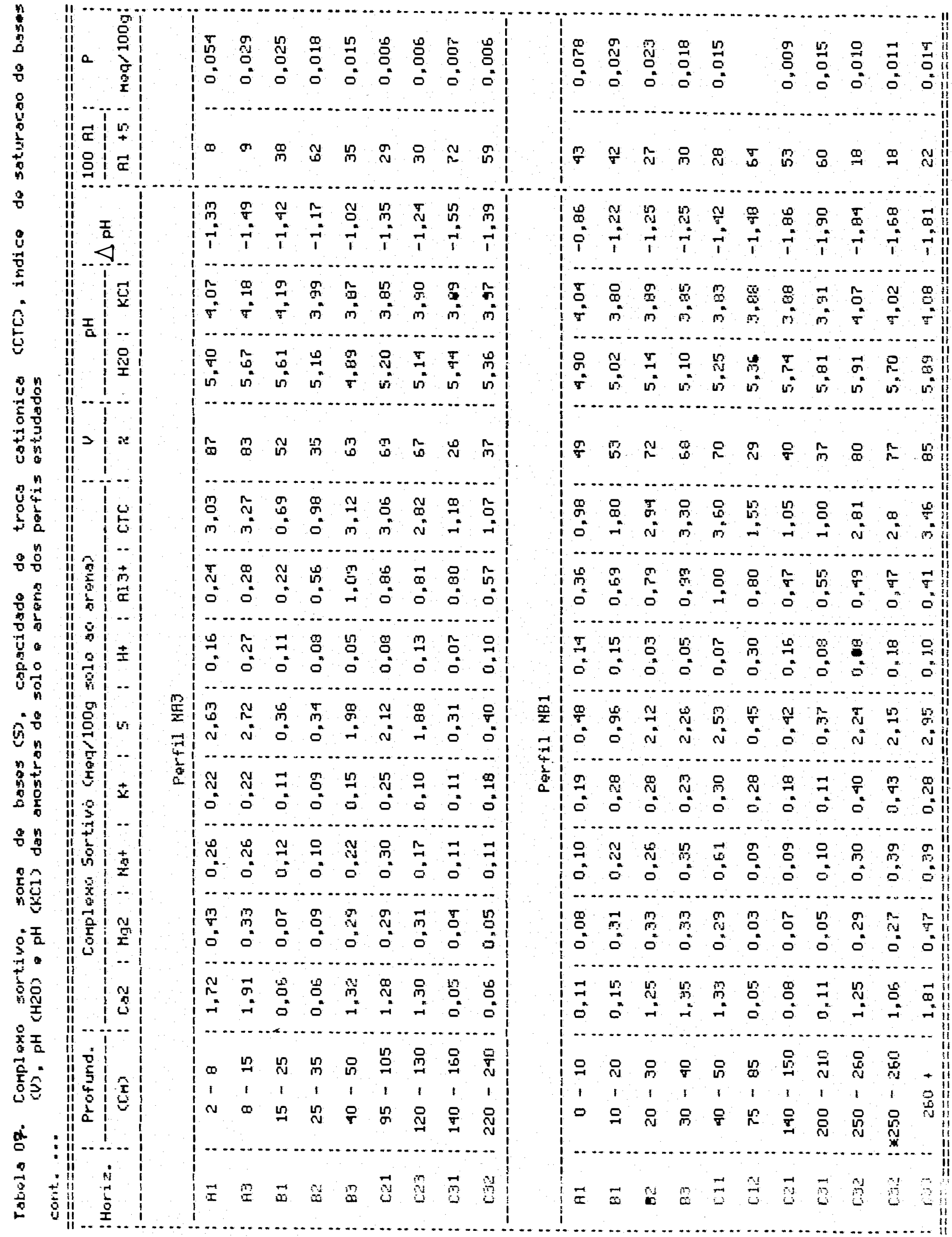


Cálcio trocável

Conforme se observa através da Tabela 07 e figura 32, os teores de cálcio trocável săo relativamente wixos nos perfis analisados, apresentando teores de 0,03 e 1,81 meq/1009, como valores mínimo $e$ máximo, respectivanente.

Na topossequência NA, observa-se que o perfil NAL, constituido por un solo Cambissoloe Jocalizado na parte mais alta da vertente, apresenta os menores teores de cálcio trocável, variando de 0,03 a 0,08 meq/100g. A sua distribuicäo em profundidade, varia de 0,06 meq/100g no horizonte superficial e declina para 0.03 meq/100g no horizonte de subsuperfície $(15$ a $25 \mathrm{~cm}) \quad E$ a partir daí, ocorre un aumento gradativo de até 0,08 meq/100g nas canadas das arenas graniticas e dos granitos pouco alterados, localizados a partir dos $40 \mathrm{~cm}$ de profundidade.

O PErfil NAE, localizado subsequentemente ao perfil NA1, ja apresenta teores de cálcio trocável bem mais elevados en relacäo ao NA1. variando de 0.04 a 1,18 meq/100g. Nos horizontes superficiais deste perfil, os teores de cálcio säo baixos, apresentando valores de 0,07 e 0,08 meq/100g. Já na profundidade de 10 a $40 \mathrm{~cm}$, os teores de calcio aumentam significativamente para valores de 1,15 e 1,22 meq/100ge, a partir dai, seus teores decrescen para niveis inferiores aos da superficie, mantendo-os até a 


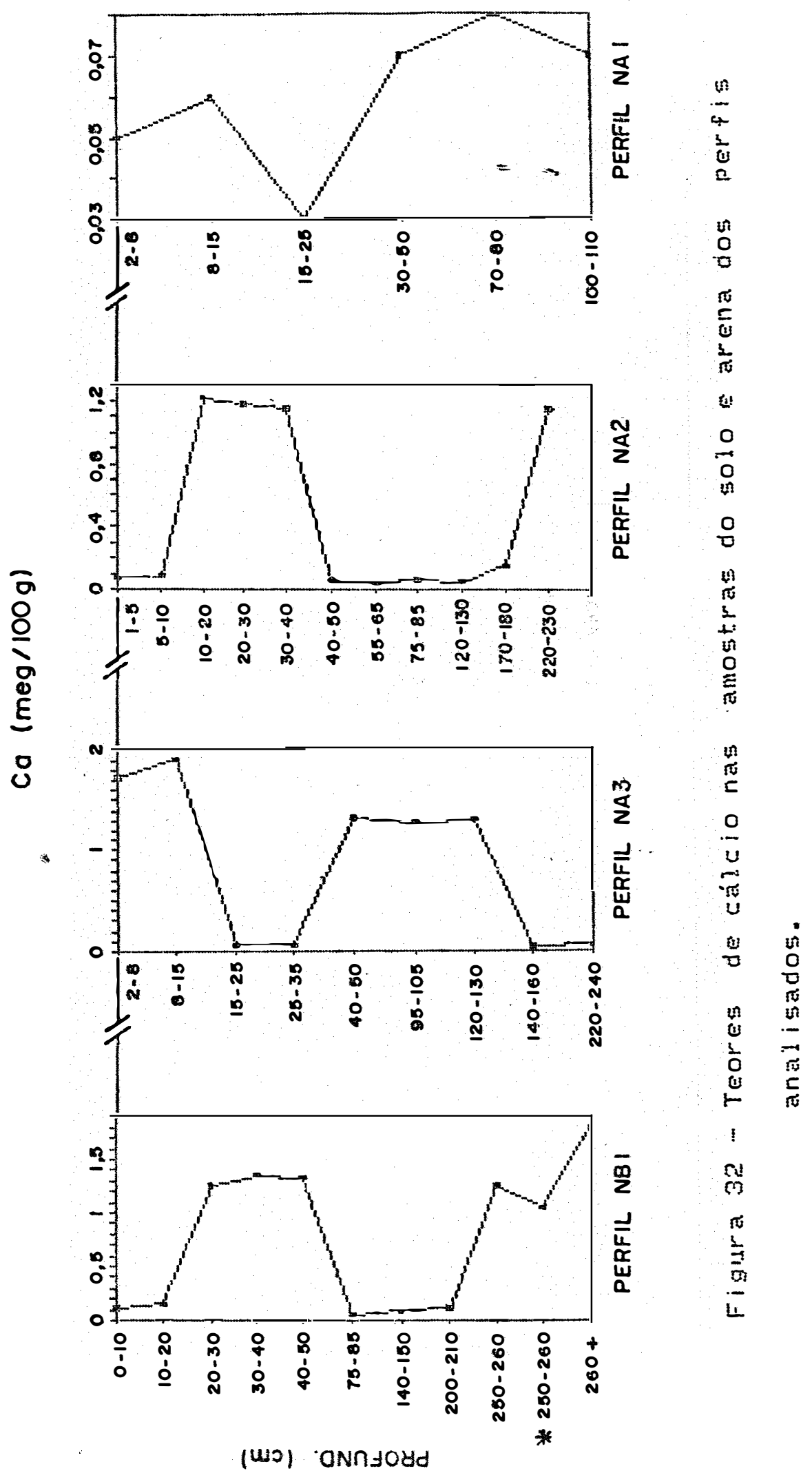


profundidade de $130 \mathrm{~cm}$. Na profundidade de $170-180 \mathrm{~cm}$, onde é comum a presenca de bolsibes de arena granitica com coloracăo mais amarelada, en funcäo do seu mais avancado estagio de intemperismo, como também, na profundidade de 220-230 cm, onde há o predominio da mesma arena amarelada (ver Apêndice 7.1 e figura 16), os teores de cálcio tornam a aumentar significativamente para valores de 1,15e 1,18 meq/100g respectivamente.

o iltimo perfil da topossequência NA, que é o perfil NA3 e, está localizado subsequentemente ao perfil NA2, apresenta os teores mais elevados de cálcio em relagáo aos demais perfis da mesna topossequência. Assin, seus teores varian de 0,05 a 1,91 neq/100g. Outro detalhe significativo demonstrado na figura 32, é que, este perfil apresenta una divergencia sisnificativa en termos de distribuicáo em profundidade do elemento cálcio trocável, en relacăo aos demais perfis analisados, una vea que, os maiores teores de calcio, ou seja, valores de 1,72 e $1,91 \mathrm{mea} / 1009$, se localizam nas camadas superficiais de $2-8 \mathrm{~cm}$ e $8-15 \mathrm{~cm} e$, a partir daí, decrescem significativamente para teores de 0,06 meq/1000 até a profundidade de $25-35 \mathrm{~cm} e$, novamente tornam a $5 e$ elevar significativamente na profundidade de 40 a 130 cm, para teores de 1,28 a 1,32 meq/100g. Novanente, teores minimos de 0,05 a 0.06 meq/1009, sắo observados nas profundidades de $140-160$ e 220-240 cm. Percebe-se desta maneira que neste perfil NA3, a distribuicăo en 
profundidade do elemento cálcio diverge de maneira oposta às aquelas verificadas nos denais perfis.

- Perfil NBI localizado na topossequência NB, a distribuigäo en profundidade dos teores de cálcio trocável de maneira bastante similar às aquelas verificadas nos pertis NA1 e NA2, mas diverge também de maneira ben evidente da distribuicáo do cálcio ver ificado no perfil NA3, conforme demonstra a figura 32.

De maneira geral pode-se afirmar que os teores de cálcio nos pertis analisados aumentan no sentido descendente da topossequência NA indicando desta maneira, que o processo de fluxo lateral do elemento cálcio está se processando nesta vertente. Na outra vertente NB näo foi possivel realizar tal observacäo porque foi analisada apenas un perfil, que é NB1.

é importante observar também que existe una similaridade muito grande quanto a distribuiço en profundidade dos teores de cálcio trocável, nos perfis NAP E NB1, apesar dos mesmos estarem localizados en vertentes differentes, mas todos embasados pela mesma rocha granitica Teles pires.

Qutro detalhe importante que deve ser mencionado, é que na maioria das vezes há coincidência entre teores mais elevados de cálcio e a presenca da arena granitica nos perfis analisados, conforme se observa nos pertis NA1 nas profundidades de $30-50,70-$ 80 e 100-110 cm, e também no perfil NA2 nas profundidades 
de $17.0-180$ e $230-236 \mathrm{~cm}$ e no perfil NB1 nas profundidades de $250-260$ e $260 \mathrm{~cm}+$.

Magnésio trocável

Na figura 33 estäo representados os teores de magnésio nas amostras de solo e arena dos perfis analisados. Pode-se perceber que seus teores säo baikos, com valores minimo $e$ máximo de 0,02 e 0,47 meq/100g, respect ivanente.

Un fato importante é que a distribuigăo en profundidade, dos teores de magnésio nos perfis analisados, apresenta um comportanento bastante similar en relacăo à distribuicăo dos teores de cálcio. Assim sendo, verifica-se que os menores teores de magnésio săo encontrados no perfil NAs $e$, há un aumento significativo no teor de magnésio nos perfis NAz e NA3. No perfil NBI também se observam os mesmos niveis de magnésio encontrados nos perfis NA2 E NA3.

Pode-se generalizar, que os

teores de magnésio nos perfis analisados aumentan no sentido descendente da vertente NA, indicando que o fluxo lateral do elenento magnésio, tambén se processa nesta vertente.

Na maioria das vezes, tambén há coincidência entre os teores mais elevados de nagnésio e a presenca das arenas graniticas nos solos analisados. 


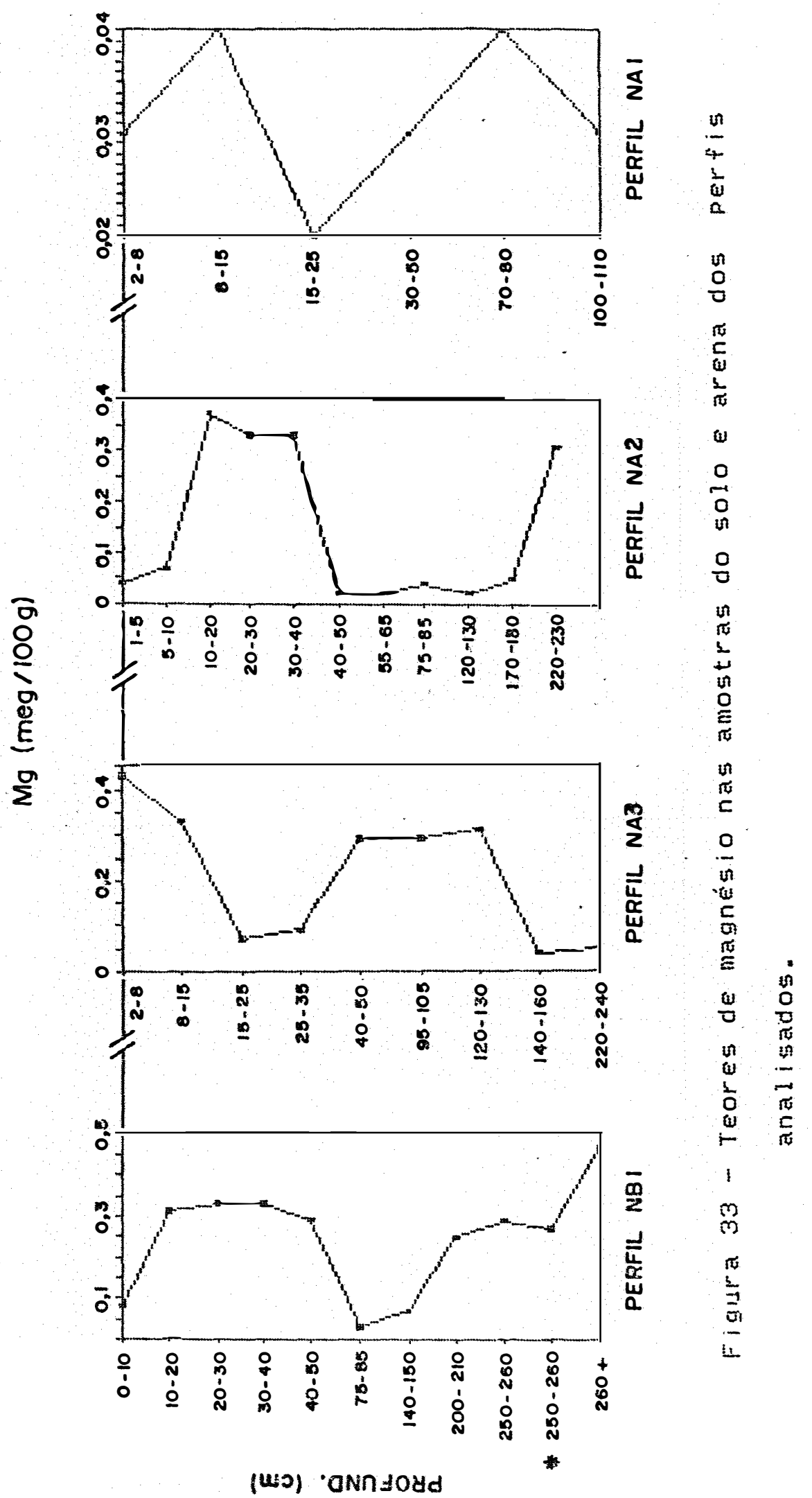




\section{Sídio trocável}

Conforme se observa na Tabela 07 e figura 34, os teores de sódio trocável säo baixos em todos os perfis analisados, apresentando valores mínimo $e$ máximo de 0,09 e 0,83 neq/1009, respect ivanente.

Observa-se que o perfil NA1, localizado na parte mais elevada da vertente NA, apresenta os menores teores de sódio e seus valores variam. muito pouco neste perfil. Na sua base, na camada de 100-110 cm onde se localiza a arena amarelada friável (ver figura 15 e Apêndice 7.13, o seu teor tende a se elevar acima da média do sels teor no perfil, atingindo ai o valor de 0,12 meq/100g.

Já no perfil NA2 observa-sena profundidade de $10-20 \mathrm{~cm}$, o teor mais elevado de scidio trocável atingindo o valor de 0,81 meg/100g, superando desta maneira todos os teores encontrados nos demais perfis analisados. A partir daí, seus teores tenden a decrescer para valores minimos, semelhantes aos do perfil NA1, mas com ligeiro aumento nas camadas onde há o predonínio da arena granitica amarelada, localizada a $170-180$ e 220-230 cm de profundidade.

No pertil NA3, os teores de sódio trocável se distribuem de maneira inversa em relacáo aos denais perfis analisados, ou seja, os seus teores sä́o maiores na superficie e na parte mediana do perfile, destescem para vaiores mínimos de 0,11 meqliogg, nas canadas onde há predomínio da arena granitica amarelada, 


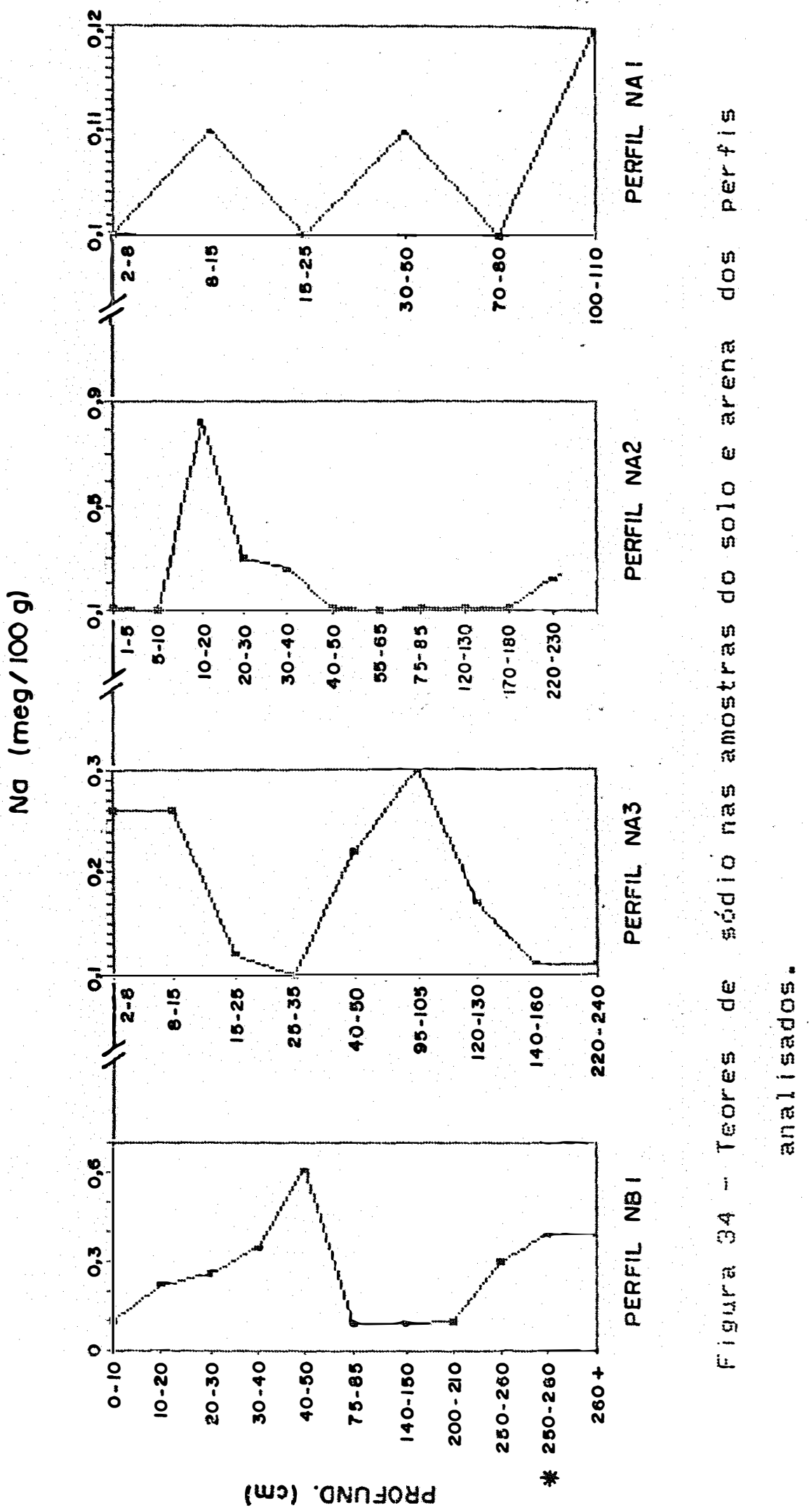


localizada nas profundidades de $140-160$ e 220-240 cm.

o perfil NBi, localizado na

vertente NB, apresenta na superficie, teor minimo de sódio $(0,10$ meq/100g), a exenplo do que ocorre nos perfis NA1 E NA2. Uma observacäo importante que deve ser mencionada é, que o teor de sudio trocável atinge na camada de $40-50 \mathrm{~cm}$ de profundidade, o maior valor deste perfil, old seja, 0,61 meq/100g. A partir dai seu teor decresce para valores minimos de 0,09 meq/100g na profundidade de 75 a $210 \mathrm{~cm}$. Entretanto, nas camadas onde há o predominio de arena granitica avermelhada, localizadas a $250-260 \mathrm{~cm}$ e $260 \mathrm{~cm}+$ de profundidade, verifica-se un aumento significativo no sel teor, atingindo valores de 0,30 e 0,39 meq/100g, respectivamente.

De una maneira gerąl, pode-se afirmar que os menores teores de sódio ocorren nas camadas superficiais dos perfis analisados, mas en profundidade, onde há o predomínio da arena granitica, observa-se ligeiro aumento dos seus teores, conforme se observa mos perfis NA1, NA2 E NB1.

Potássio trocável

A figura 35 representa a distribuifäo em profundidade, dos teores de potássio trocável nos perfis analisados, os quais variande 0,09 e 0.59 mequeso, como valores minimo e maximo, respect ivamente.

No pefil NA1, o teor de potássio 


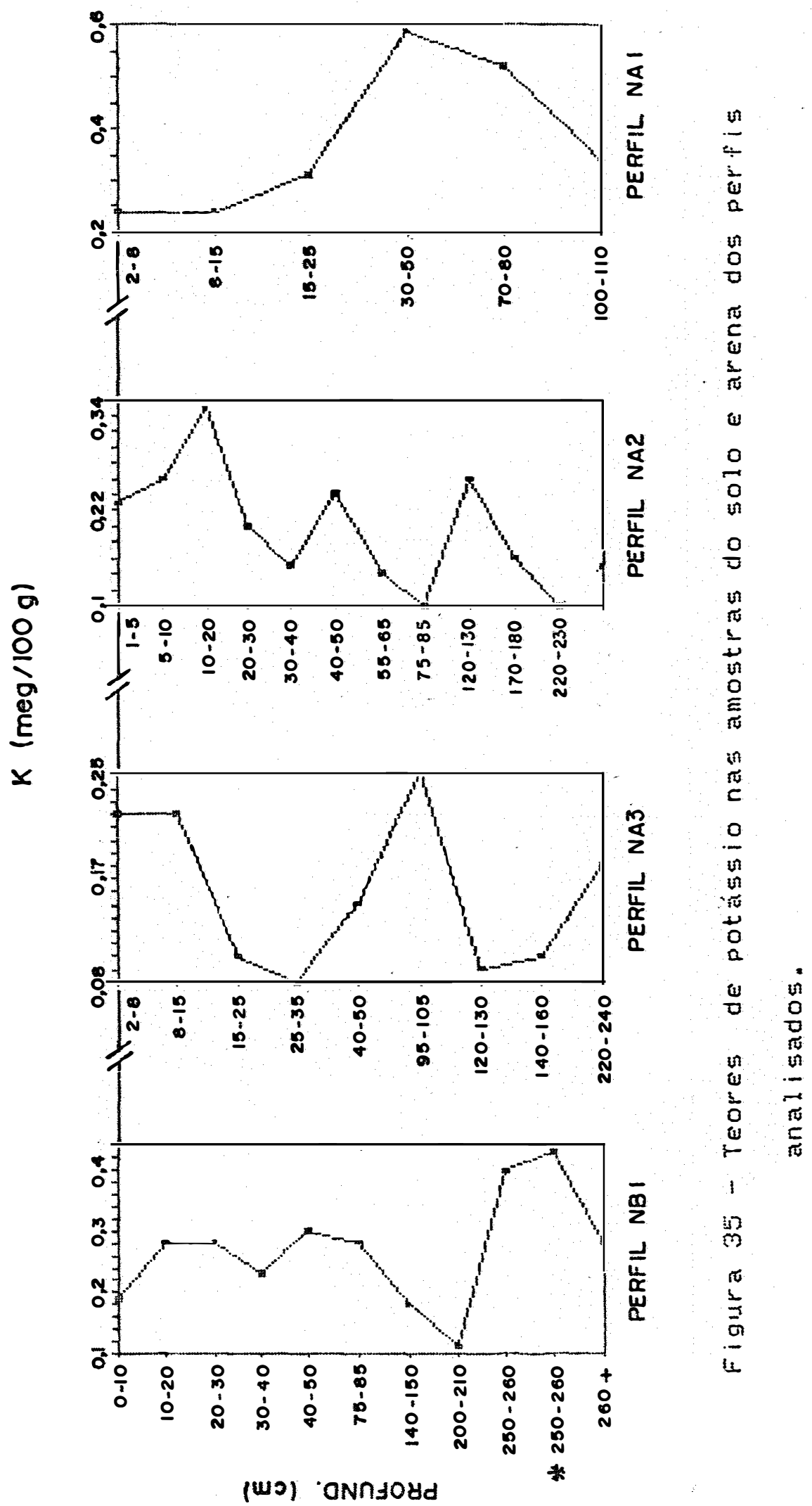


trocável é baixo na superficie, mas en profundidade, seus teores aumentan significativamente, principalmente nas camadas onde se localiza o granito pouco alterade, ou seja, nas camadas de $30-50$ e $70-80 \mathrm{~cm}$. Já na camada da arena amarelada friável, verifica-se que o seld teor decresce acentuadamente para valores poucos superiores aos das camadas superficiais. É importante ressaltar que este perfil (NA1), apresenta os maiores teores de potásio trocável en relacăo aos demais perfis que seráo apresentados logo a segidir.

No perfil NA2, observa-se que os teores de potassio trocável săo bem inferiores aos de perfil NA1 e a amplitude da variagäo dos seus teores é pequena, ou seja, varia de 0,10 a 0,35 meq/100g, como teores mínimo e máximo, respectivamente. Nas camadas onde há o predomínio da arena amarelada, os seus teores săo inferiores aos observados na superficie.

o perfil NA3 apresenta teores de potássio, inferiores aos do perfil NA2, os quais varian de 0,9 a 0,25 meq/1009. A sua distribulcáo até a profundidade de $120 \cdots 130 \mathrm{~cm}$, apresenta grande similaridade com a distribuigáo do elemento sódio trocável, mas esta semelhanga desaparece a partir das camadas de 140-160 e 220-240 cm de profundidade, pois verifica-se um leve aunento nessas camadas en que há maior predominio da arena granitica amarelada.

Apesar do perfil NB1 estar 
localizado nowtra vertente, apresenta teores de potássio em niveis ben proximos aos do perfil NA1. Seus teores variam de 0,11 a 0,43 meq/100g como valores minimo e máximo, respectivanente. Ds seus teores variam muito pouco desde a superficie até a profundidade de 75-85 cm, apresentando teores de 0,19 a 0,28 neq/100g. Na profundidade de $200-210 \mathrm{~cm}$ o seu teor decresce para o nivel minimo de 0,11 meq/1009. Verifica-se emi seguida, un aumento significativo para teores de 0,40 a $0,43 \mathrm{meq} / 1009$, nas camadas de $250-260$ e $260 \mathrm{cnt}$ onde há o predominio da arena granitica avermelhada.

De modo geral pode-se afirmar que, os maiores teores de potássio trocável sấ verificados no perfil NA1, constituidos for um solo Cambissolo menos evoluido que os denaise, en seguida, no perfil NB1, tantén constituido por un solo Cambissolo ben menos evoluido do que os perfis NA2 e NA3.

$$
\text { Verifica-se também que há. un }
$$

decréscimo significativo do teor de potássio no sentido descendente da topossequência NA, indicando que a remoçó do potássio foi bem maior nos perfis mais evoluidos, os quais serian o NA2 E NA3.

$$
\begin{aligned}
& \text { Soma de bases - } " S " \\
& \text { Conforme se observa na Tabela }
\end{aligned}
$$

Q7. O perfil que apresenta os menores teores en bases é o NA1, localizado na parte nais alta da vertente NA, pols - mesmo apresenta valores de $S$ que varian entre 0,42 a 
$0,80 \mathrm{meq} / 1009$. Já, nos demais perfis, verifica-se que os valores de $S$ săo mais elevados e variam de 0,30 a 2,95 meq/100g.

Verifica-se no perfil NAI que o valor de $S$ ébaixo nas camadas superficiais $e$ a mesma tende a se elevar nas camadas onde se localizam o granito pouco alterado e a arena granitica amarelada. Observa-se que o perfil NA1 apresenta a seguinte orden decrescente en termos percentuais médios dos teores de cada base trocável: - perfil NA1 =K(60\%) $\mathrm{Na}(20 \%)>\mathrm{Ca}(11 \%)>\mathrm{Mg}(6 \%)$ Percebe-se assim que há o predominio das bases monovalentes, principalmente o potássio que detem $60 \%$ da soma total das bases. Este teor bastante elevado do potássio, proven especificamente do intemperismo dos feldspatos potássicos presentes nesta rocha granitica, pois os teores do potásiónas camadas superficiais dos solos analisados săo baixos, mesmo considerando que a decomposicấo da matéria orgânica libera grande quantidade de potássio na maioria dos solos.

\section{Os valores de $S$ calculados para}

os perfis NA2 E NB1 demonstram o mesmo comportamento em. profundidade. Os seus valores säo balios na superficie e na porgáo mediana dos perfis. Na faixa aproximada de 10 a 40 cm de profundidade e nas camadas onde há o predomínio das arenas graniticas, os valores de $S$ se elevam acentuadamente para valores de até 2,95 meq/1009.

Já no perfil NA3 observa-se uma tendência inversa com relacăo aos valores de $S$ en 
profundidade. Verifica-se portanto que nas camadas mais superiores deste perfil e nas camadas compreendidas entre 40 a $130 \mathrm{~cm}$, os valores de $S$ säo bem mais elevados en relacăo as camadas de $15-25$ e $25-35 \mathrm{~cm}$ de profundidade $e$ nas camadas onde há o predominio da arena granitica anarelada.

A correspondência en termos percentuais médios dos teores de cada base trocável no valor de soma de bases - " $S$ " dos perfis NA2, NA3 e NB1 é resumida da seguinte maneira:

- Perfil NA2 $=\operatorname{Ca}(34 \%)>\mathrm{K}(31 \%)>\mathrm{Na}(23 \%)>\mathrm{Mg}(12 \%)$

- perfil $N A 3=\operatorname{Ca}(44 \%)>K(20 \%)=N a(20 \%)>M g(16 \%)$

- perfil NB1 = Ca $(40 \%)>\mathrm{K}(26 \%)>\mathrm{Na}(19 \%)>\mathrm{Mg}(16 \%)$

Verifica-se assim, que há predoninio do cátion bivalente cálcio nos perfís NA2, NA3 e NB1, exceto do perfil NA1, já mencionado anteriornente.

\section{Hidrogênio e Alumínio trocáveis}

Conforme se observa na figura 36. en todos os perfis analisados, os teores de $H$ trocável säo inferiores aos teores do Al trocável. Percebe-se também que a amplitude de variaräo dos teores de ${ }_{H}^{+}$é ben menor se comparado a do $\mathrm{Al}^{+3}$.

No perfil NA1, nota-se que o menor $e$ o maior teor de $H$ atinge valores de 0,03 e 0.25 mea/100g sendo que o menor teor foi verificado na amostra da arena anarelada coletada a $100-110 \mathrm{~cm} d e$ profundidade. 0 At3 também se apresenta na superficie 


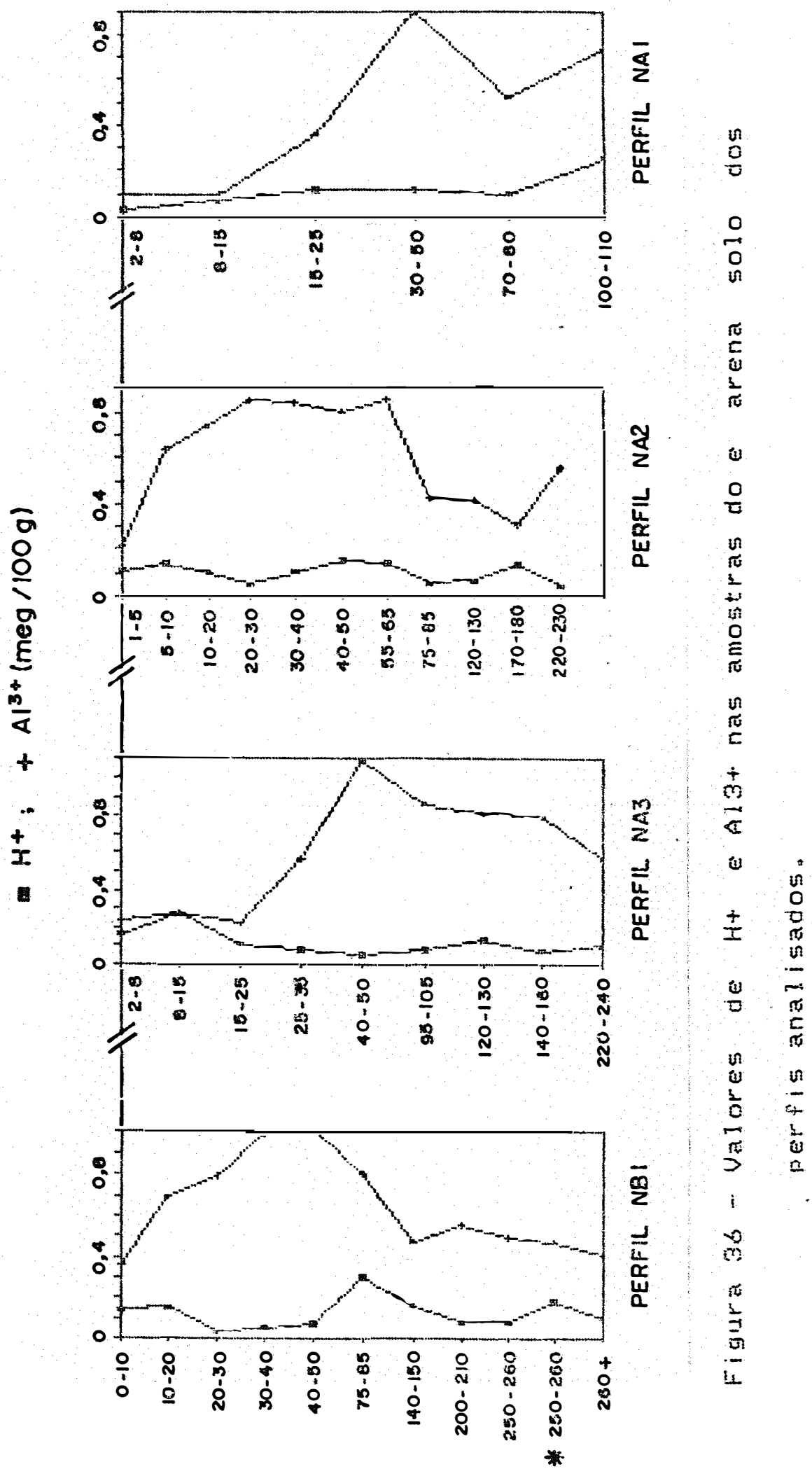

(uiv) ONnJOYO 
en menor teor $(0,10$ meqliog), mas na profundidade de 30 . 50 cm, 0 seu teor se eleva acentuadamente para 0,90 nealiooge, em seguida decresce un pouco, nas camadas em que se localizan os granitos pouco alterados e a arena granitica amarelada.

Nos demais perfis NA2, NAB E NBI os teores de $\dot{H}$ também variam pouro, apresentando teores de 0,03 e $0,30 \mathrm{meq} / 1009$ como valores minimo e máximo. No entanto, a distribuicäo en profundidade dos teores de $+3$

A] varian bastante, apresentando valores de 0,21 a 0,99 meq/100g, mas verifica-se uma tendencia similar quanto à sua distribuitäo en todos esses pertis.

Capacidade de troca de cátions"CTC"

Através da Tabela $\theta 7$, observa-se que a CTC apresenta grande variagáo em profundidade nos perfis analisados.

No perfil NAI há um aumento da CTC em profundidade, sendo que na proturididade de $30-50$ percebe-se o valor mais elevado da cre atingindo o valor de 1,8e meq/1099, coincidindo exatamente com a camada que apresenta maior teor de argila $(38,6 \%)$ neste perfil (ver Tabela 06 e figura 29 ).

No perfil NAe também se observa o incremento da cre para valores de ate 2,94 mequgon, na profundidade de $10-20 \mathrm{~cm}$, mas a partir dai, percebe-se un decrescimo gradativo até a profundidade de $120-190$ cme, 
novamente sofre un incremento para valores de até 2,55 meq/100g, nas camadas onde ha o pradonínio das arenas graniticas amareladas. Esta mesma tendência é constabaca no perfil NBi, quanto à distribulfăo en profiundidade dos valores da CTC.

Já no pertil NA3, ocorre nitida divergência dos denais perfis quanto ao comportamento da CTC en profundidade. Inicialmente, apresenta na superficie valores de CTC maiores com valores de 3,03 e 3,27 meq/100g nas profundidades de $2-8$ e $8-15$ cm e logo após, um declinio para valores minimos de 0.69 e 0.96 meq/100g nas profundidades de $15-25$ e $25-35$ ch $e$, a partir dai, verifica-se novamente un incremento para valorez de ate 3,12 meq/100g na faika de $40-130 \mathrm{~cm}$ de profundidade en segidida, declina novamente.

A variabilidade atípica da crc em profundidade nesses solos se deve principalmente à sua fracăo mineral, já que os seus teores de matéria orgânica, subentendidos em termos de \%

\section{Saturagão en bases - "U\%"}

Com relatăo à gaturatäo de bases, percebe-se que o pertil NAS apresenta o niaror percentual de saturacäo de bases nas camadas superficiais dos perfis analisados, con valores de ate $87 \%$, vindo a seguir o perfil NAs apresentando valores de até $76 \%$ A tendencia observada nesses dois perfis é um declinio em profundidade, do indice de saturafäo de bases, comi algunas 
alternâneias de incremento/decréscimo.

Entre os pertis NAE E MBS. Existe uma certa similaridade na distribuicáo em profundidade, dos seus valores percentuais, divergindo apenas nas camadas superficiais do perfil NAs. Ohserva-se nesses dois perfis que os indices de saturacáo de bases se elevam nas camadas supericiciais e decrescem na profundidade mediana at ingindo niveis de ate $23 \%$ na camada de $55-65$ cin de profundidade do perfil NAP, resultando consequentamente num indice de saturacăo de aluminio de $74 \%$, conferindo portanto, un caráter álico nesta camada. Este mesmo fato é observado no perfil NA3 na protundidade de $140-160$ cm, onde o indice de saturakáo de bases atinge o valor de $26 \%$ e o indice de saturacäo do alumínio som o valor de $72 \%$, conferindo também o carater álico. Assim sendo, tais caracteristicas indicam que esses dois perfis NA2 E NA3 sấo os mais intemperizados da topossequência NA.

\section{$0 \mathrm{PH}$ en H?Q, KCI $\mathrm{K} \triangle \mathrm{PH}$ \\ Ds valores de pH en HaO estäo} variando de 4,4 a 6,3 nos quatro perfis analisados iver. Tabela 07 e Figura 37$)$. Somente o perfil NA1 que apresentou valor de pH mais elevado na superficie do seu solo, on seja, $p H=6,7$ e em protundidade houve un decréscimo do $p H$, atingindo uma acidez maxima na porgäo mediana $(30-50 \mathrm{~cm}$ de profundidadel deste perfil. Todos os outros perfis, ou seja o NA2, NAB e NBI apresentaram valores de pH quase homogêneos, en profundidade. 


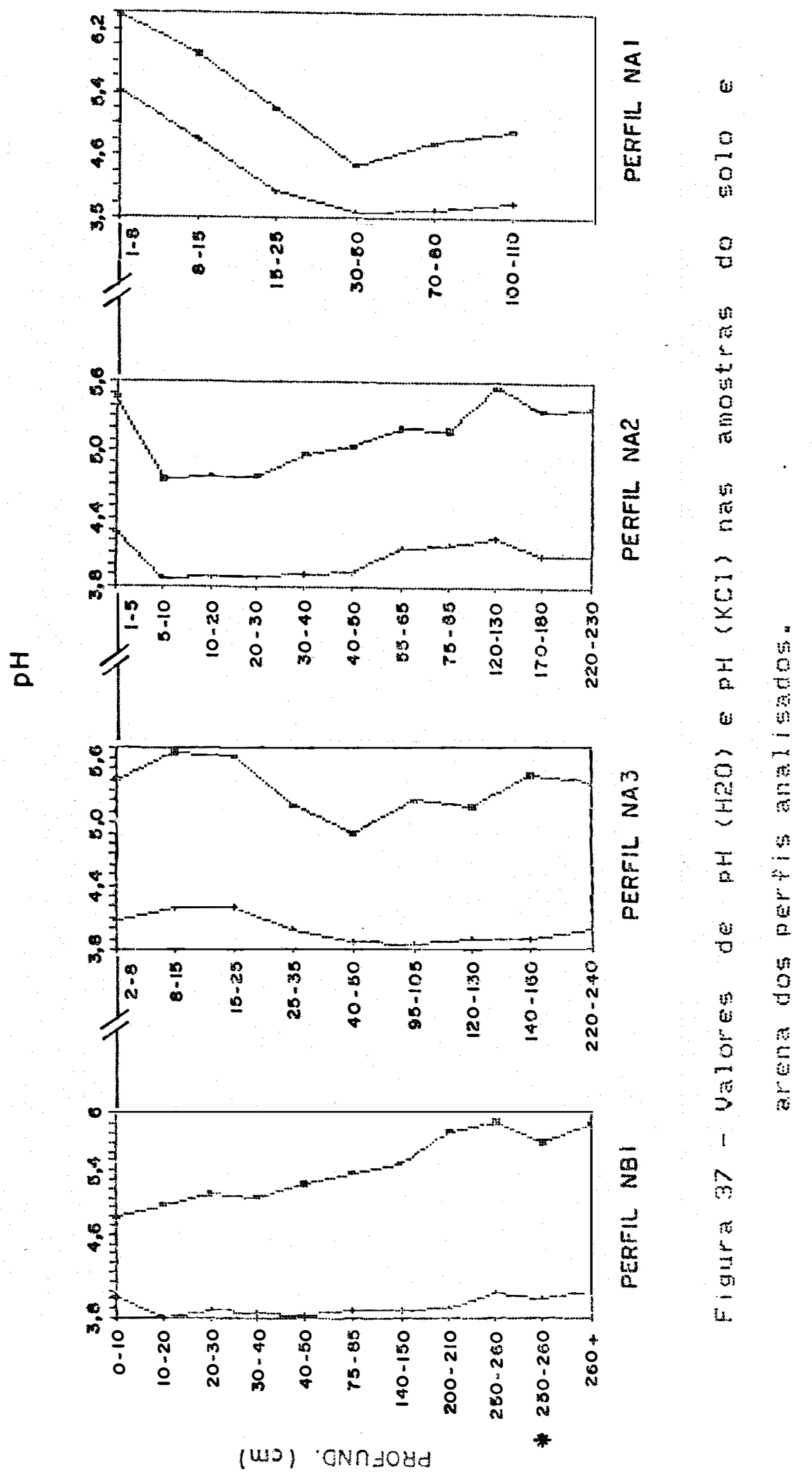


Os valoresi de pH dererminados em

KC1, apresentaran também, comportamento idêntico ao do pH em Hao mas, com valores sempre inferiores, dando como resultados valores de $\triangle \mathrm{pH}$ (= $=\mathrm{PHKCl}$ - PH HaO s sempre negativos, indicando que os solos dos perfis analisados, apresentan excesso de carga negativa.

Ds teores de físforos säo bastante baixos, a exemplo do que ocorre nos solos da amazionia.

\subsection{2 - Fase liquida - Solugäo do solo.}

Neste iten será apresentada inicialnente a discussáo dos resuitados obtidos através das análises qualitativas e quantitativas dos principais ions que compiem os extratos da solucăo do solo obtidos a partir das amostras de solo e arena dos perfis NA1, NA2, NA3-e NB1. Posteriormente será realizado o balango iônico da soluria do solo, segidida pela análise termodinâmica a partir da concentrafáo dos seus ions para fins de avaliar suas intluências na estabilidade dos minerais neotormados no transcorrer da pedogênese.

\subsubsection{1 - Composicăo quimica da solugăo do 5010}

As tabelas $08,09,10$, e 11 apresensam os resultatow das andises quindeas realizadas na solucăo do solo extraida das amostras de solos e arena desenvolvidos a partir da alterafáo local do aranito 


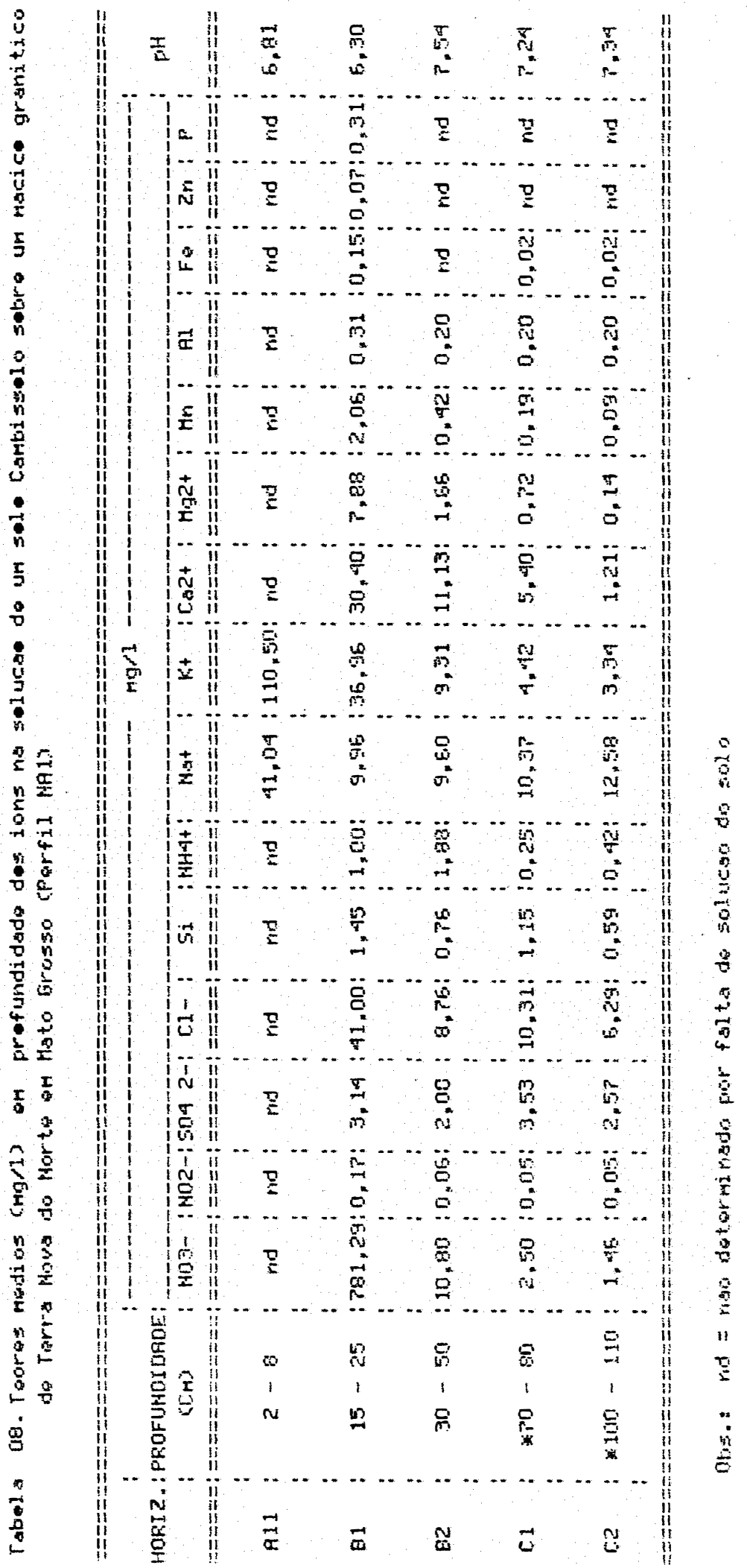




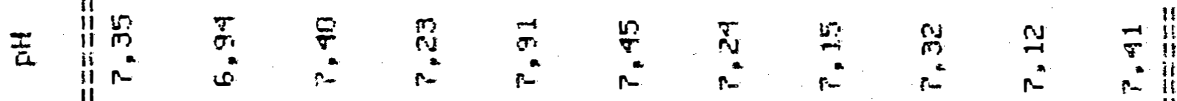

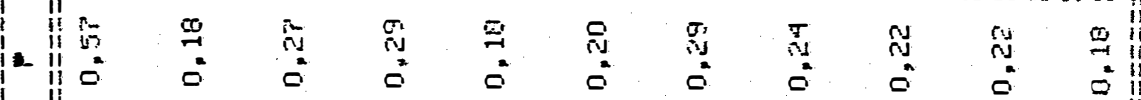

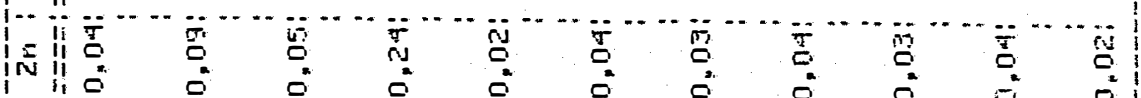

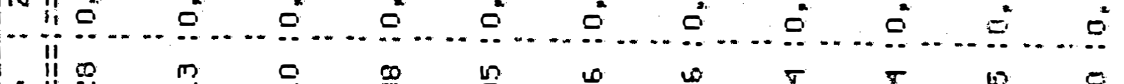

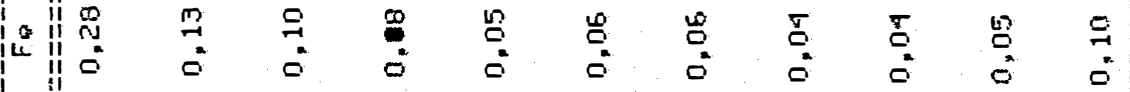

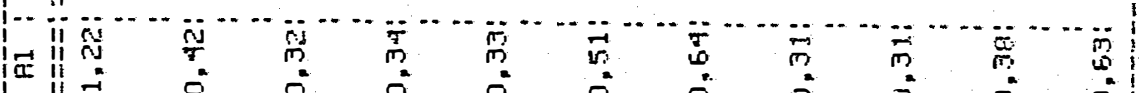
..

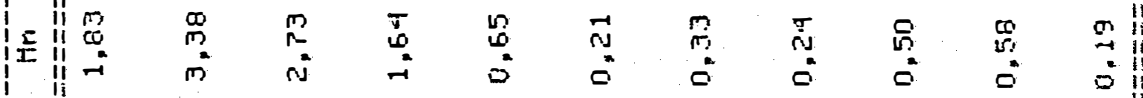

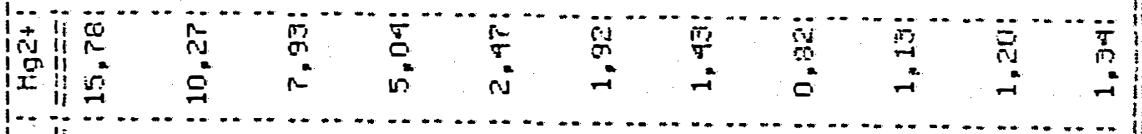

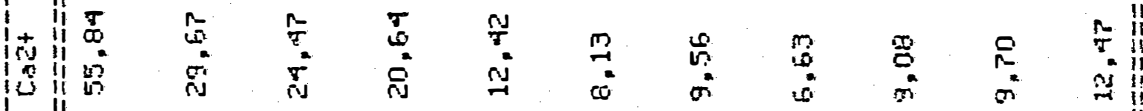

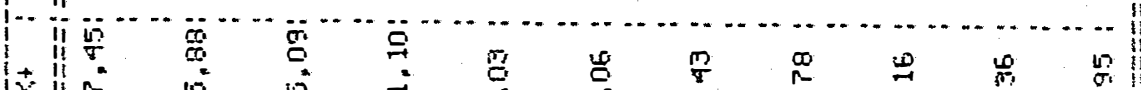

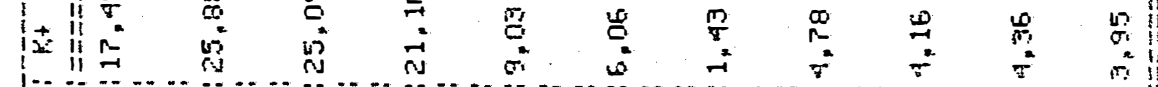

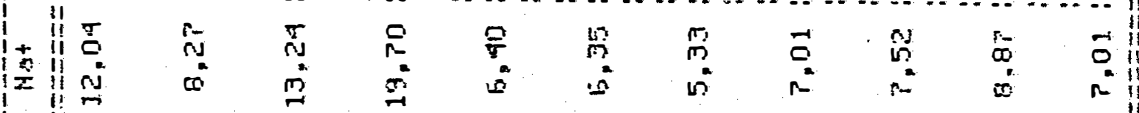

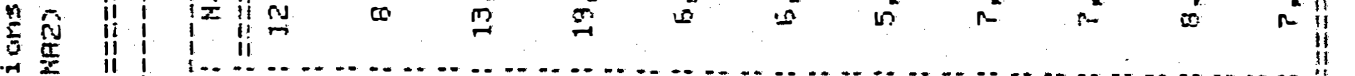

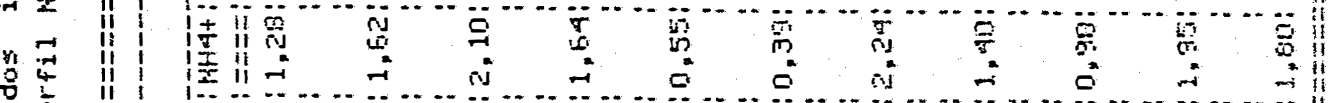

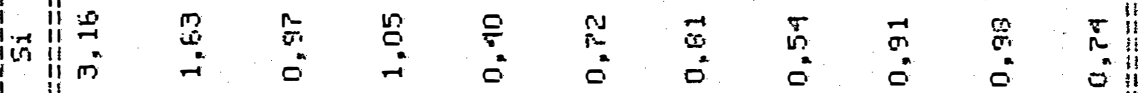
1

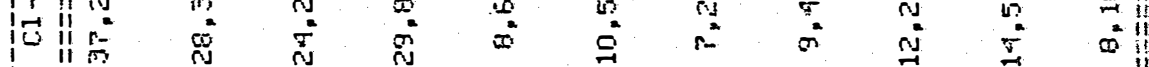
.........................................

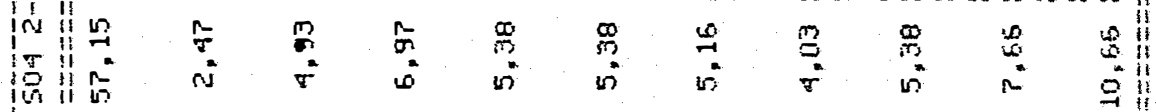

福

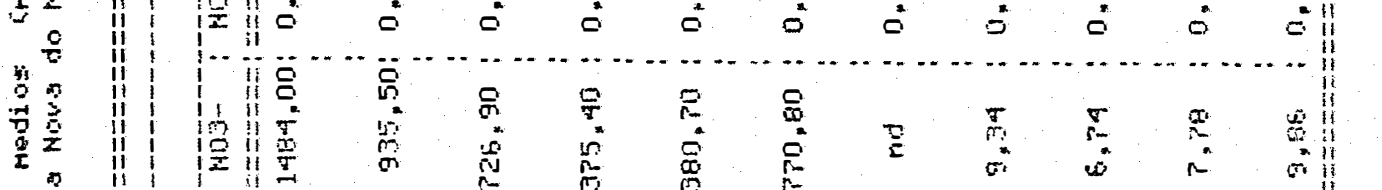
$n$,

告 告 


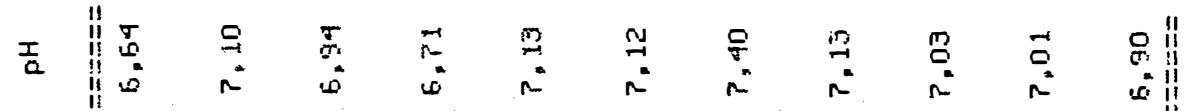

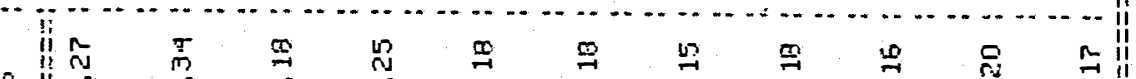

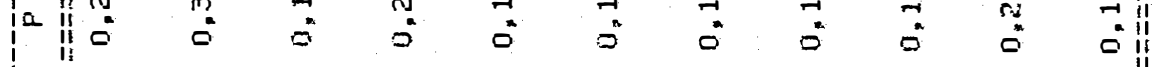

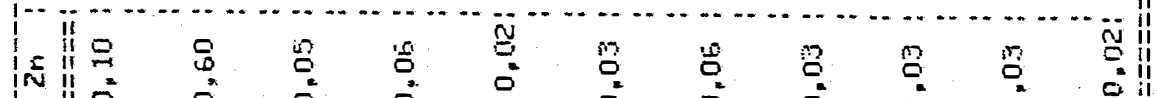

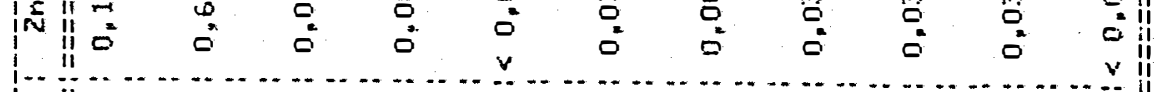

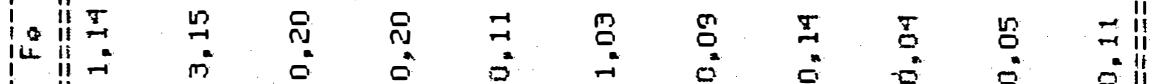

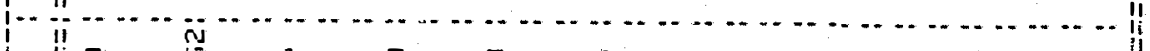

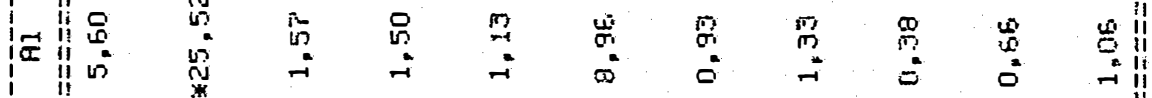
- 11 \%

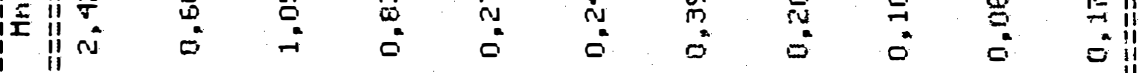

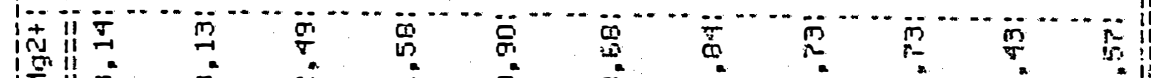

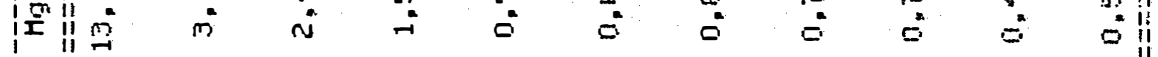

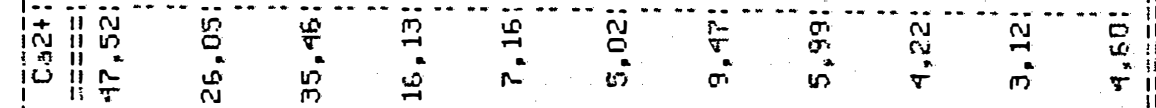

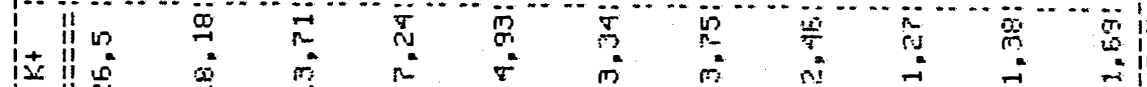
11

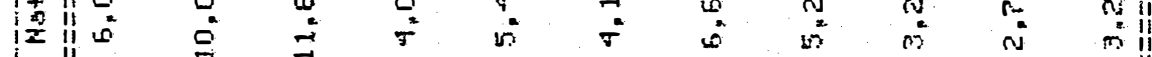

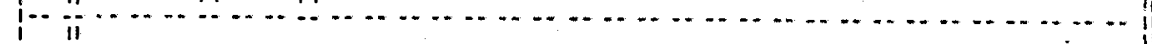

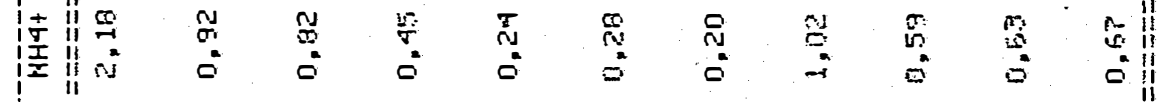

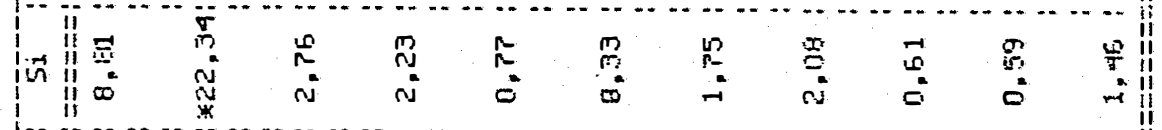
1

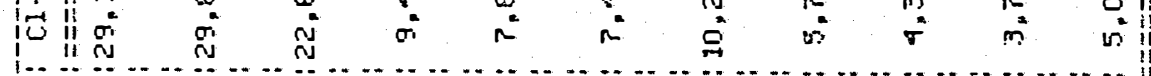
1i

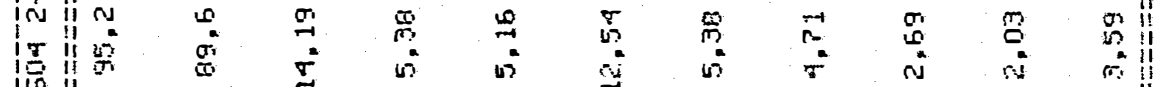

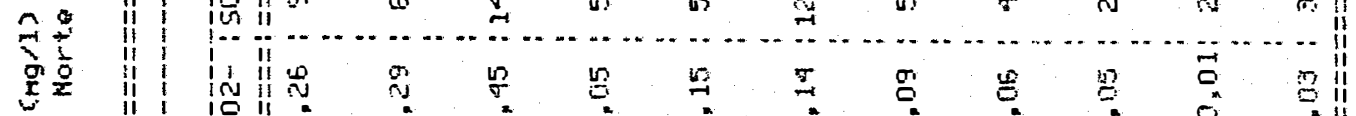
$n$
$n$ 1) ar a n $n$ a n

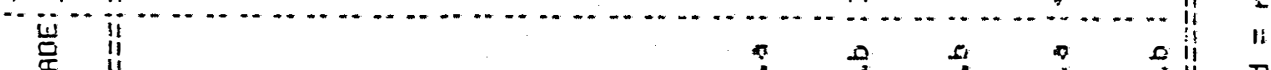

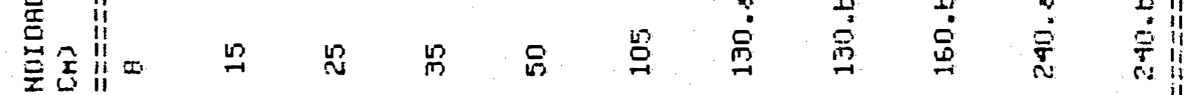
$\stackrel{9}{9}$

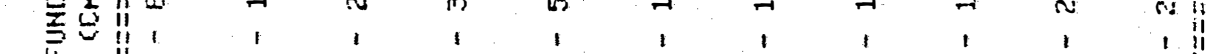




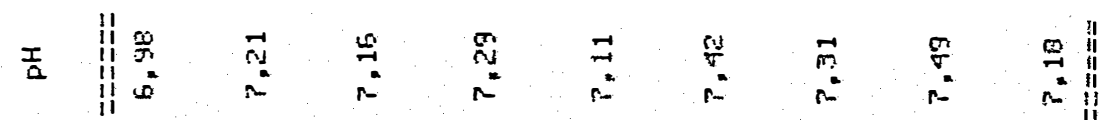
a.

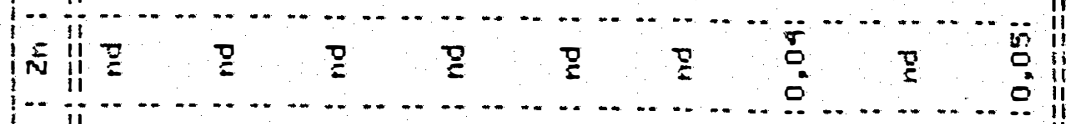

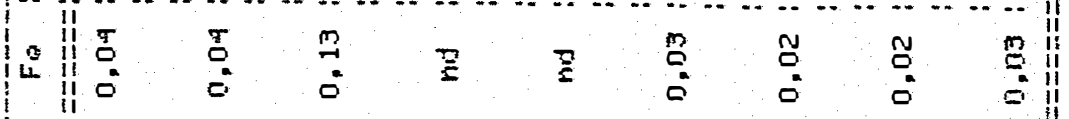

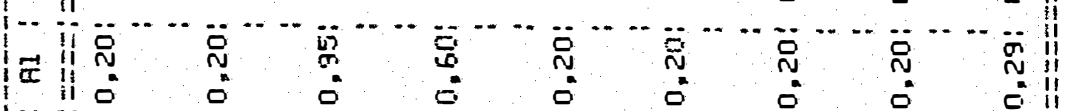

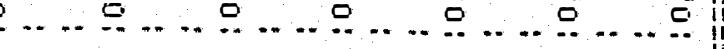

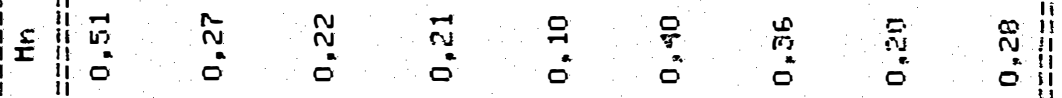
薄

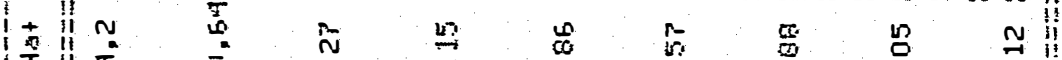

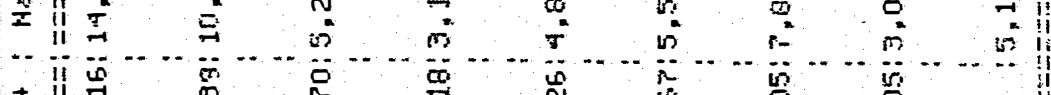

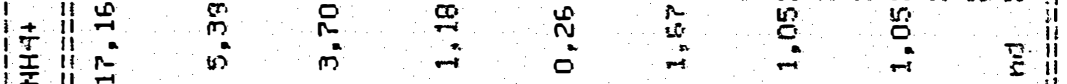

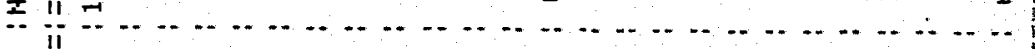

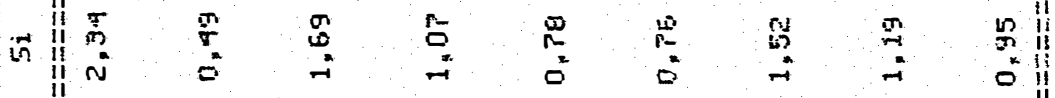

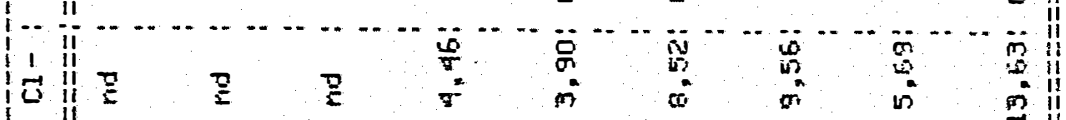

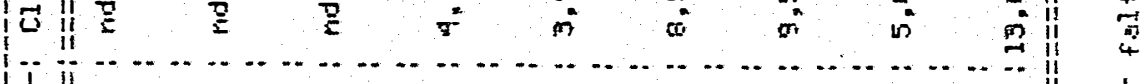

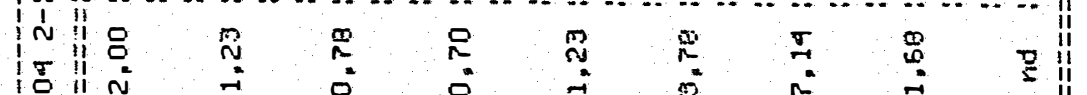

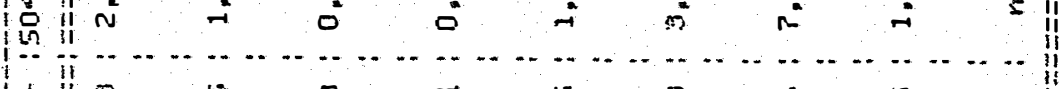

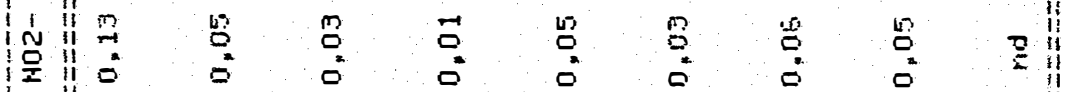

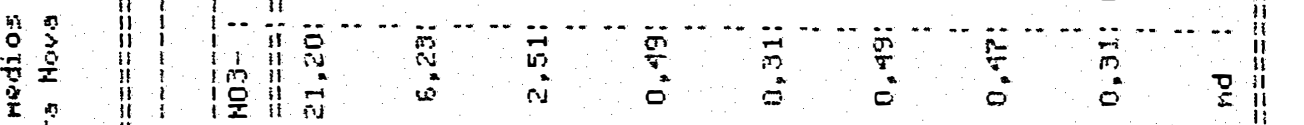

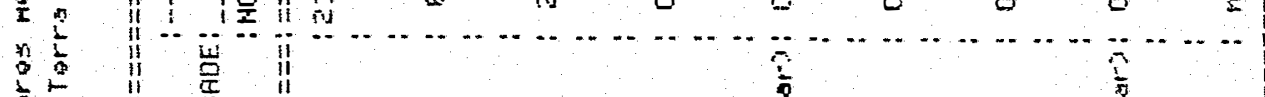




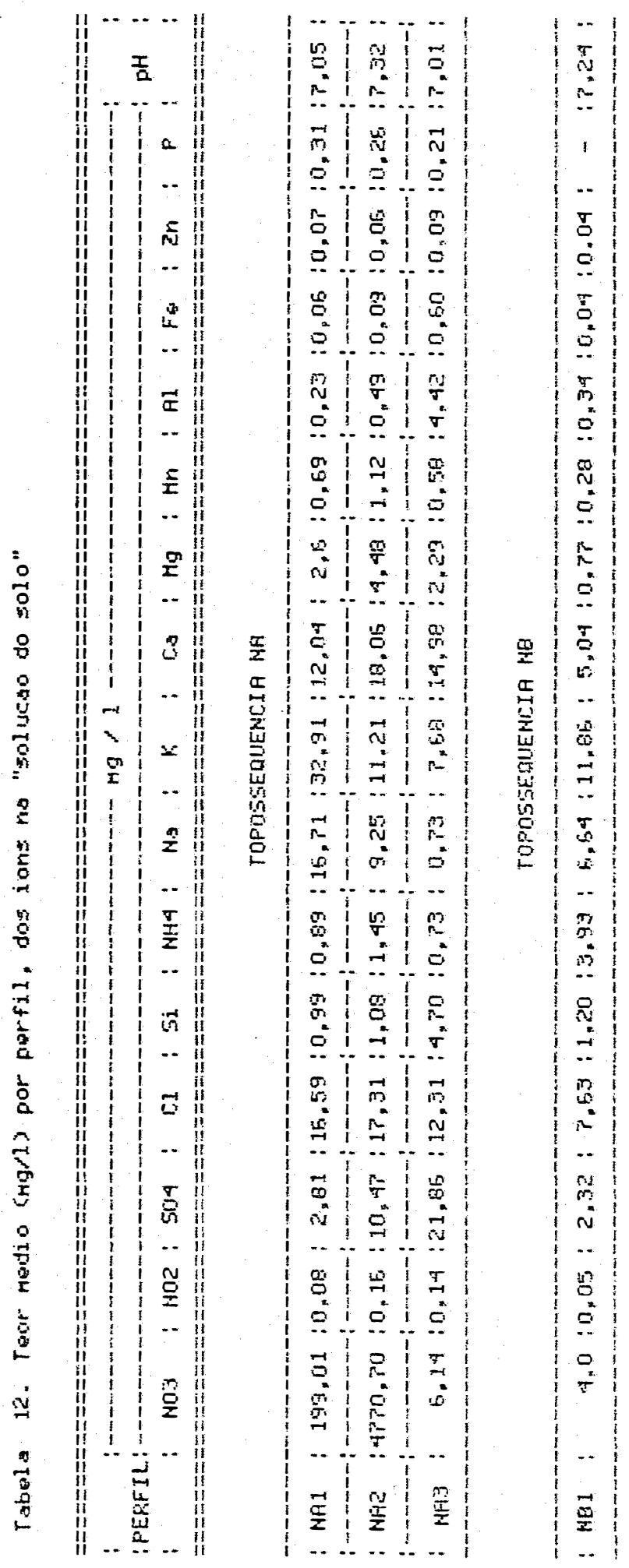


denominado Teles pires. A caracterizacáo e a dosagem foram feitas por espectrototometria de absorcäo $e$ tambeñ por espectrometria de emissáo atômica com plasma induzido de argônio. As mesmas tabelas, também apresentan os dados referentes ao PH da solugäo do solo, determinados potenciometricamente com duas repetigís na leitura.

Desta maneira, foran caracterizados qualitativamente $e$ quantitativamente nas solucises extraidas, os seguintes ions: nitrato, nitrito, sulfato, cloreto, silicio, amônio, sódio, potássio, cálcio, magnésio, manganês, aluminio, ferro, zinco, fústoro $e$ valores de pH.

\section{Nitrato}

Conforme se observa na figura 38, os teores de nitrato na solugäo do solo extraidz das amostras de solo e arena dos perfis analisados, sáo bastante elevados na porgäo superficial do solo $e$ a tendência ediminuir gradativamente en profundidade para teores minimos, conforme se nota nos perfis NA2 $E$ NBi. Este fato pode ser explicado pela forte atividade de mineralizacăo da matéria orgânica cdeposita áa constantemente pela floresta), promovida pela bionassa microbiana sempre presente en maior quantidade nos horizontes superficiais.

Fazendo una comparabo dos teores de nitrato apresentados pelas amostras do perfil NA2 e do NB1, percebe-se que as suas tendencias en termos de 

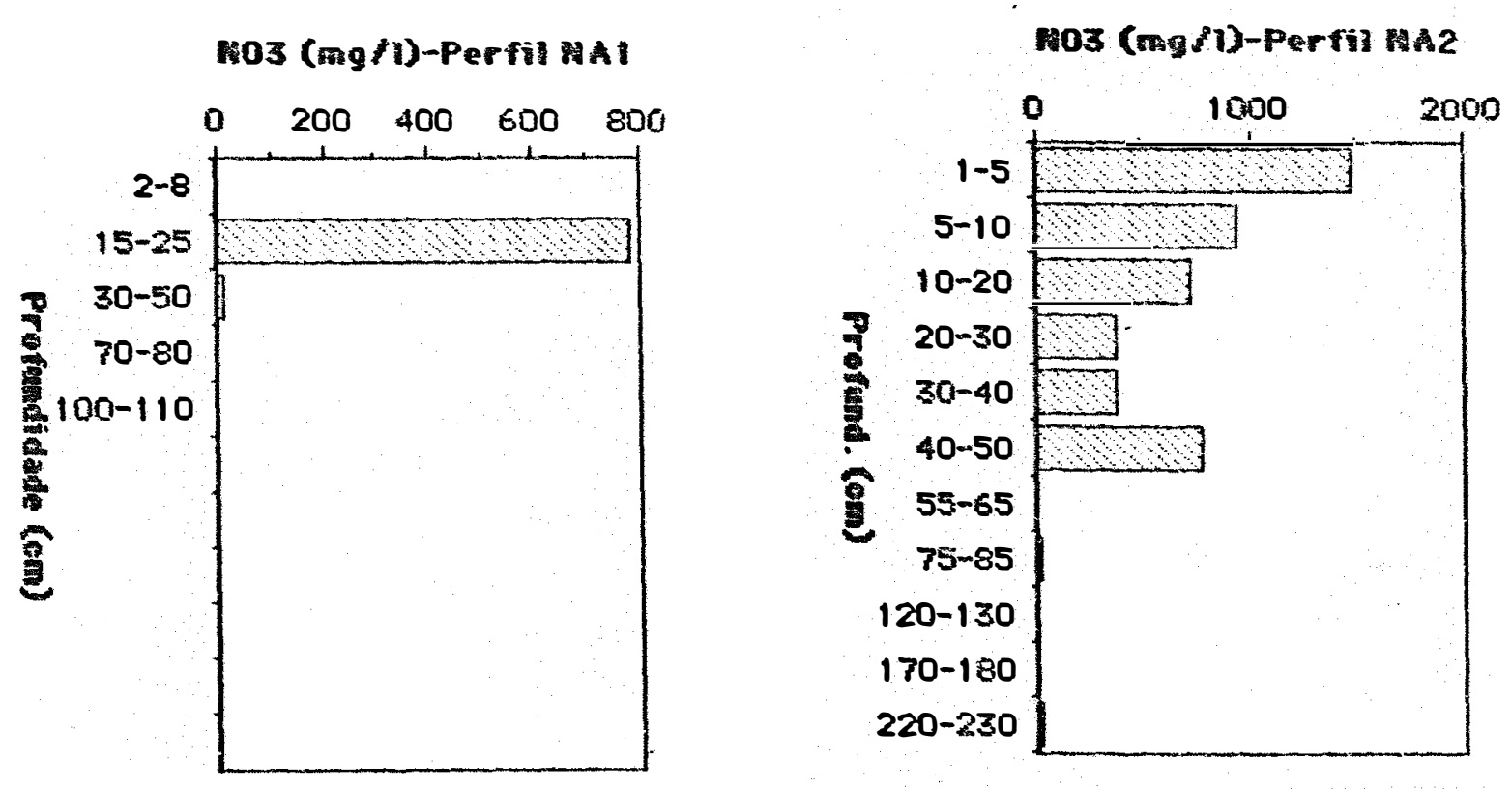

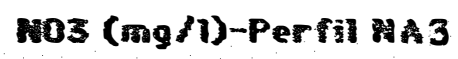

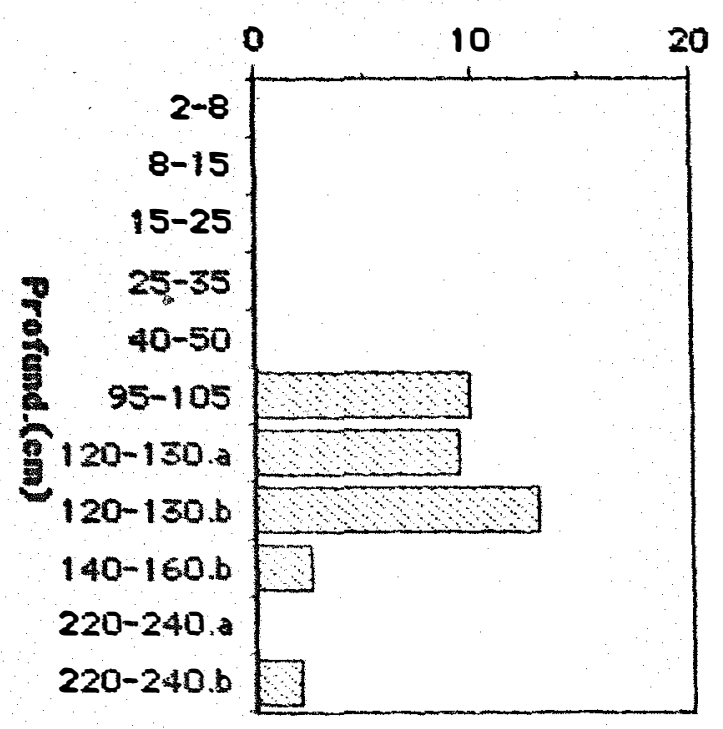

$\operatorname{mos}(\mathrm{mg} / 1)-\mathrm{Perfi1})$

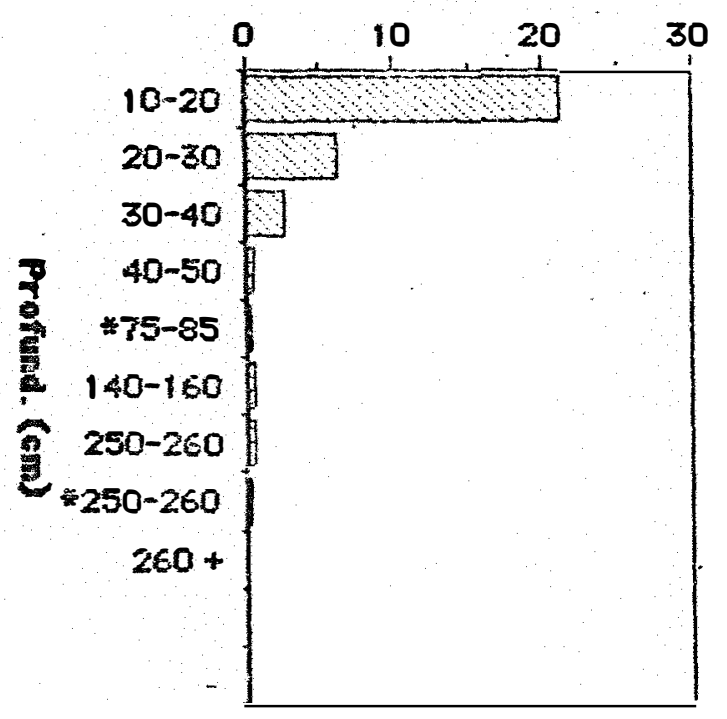

Figura 38 - Distribuiga em profundidade dos teores as nitrato na solubäo extraida das amostras de sodo e arena dos perfis analisados. 
distribuicäo em profundidade, sä́ similares, entretanto, diferen bastante en termos de quantidade (expressa en mg,l). Isto, segundo KINJo et ali $i$ (1978), ocorre porque a transformacäo do nitrogênio orgânico para inorgânico, säo processos de natureza bioquimica, envolvendo a atividade da biomassa microbiana do solo e consequentemente, a quantidade de nitrato produzida dependerá das condicies que atetam a atividade dos diversos microorganismos de solo. responsáveis pela transformacäo do nitrogênio. orgânico en amônio, nitrito e finalmente en nitrato. Por SHa VEZ, ALLISON \& STERLING (1949), citados por KINJO et ali i (1978), observaram que a producäo do nitrato estava diretamente relacionada com o teor de nitrogénio total do solo e que a variacăo da nitrificacâo en diferentes solos poderia ser atribilida à natureza dos microorganismos presentes no solo, à reacäo do solo, teor de fístoro e de outros elementos que afetam a atividade dos microorganismos. Ds fatores que afetam os microorganismos do solo, segundo SIQUEIRA \& FRANCO - 1988, podem ser facilmente identificados, mas sua importância relativa é dificil de ser claramente definida, pois pode resultar da acăo de uma ou mais variaveis isoladas e de suas numerosas interacos. A alteraco de qualquer caracteristica do solo (fisica, quimica ou biolioica) implica en alterafós das demais, como por exemplo, a

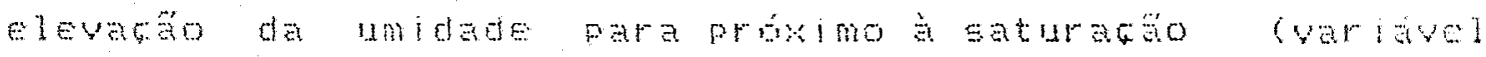
fisica) resulta en redugáo na aeracáo (oxigênio), e consequentemente, reduz a atividade dos microorganismos 
aeribicos e favorece a dos microaerbios e anaerbubios (variável biológica), modificando assim o metabolismo global do solo, passando de + oxidativo para redutivo, acumulando metais reduzidos. NHA, Has e produtos da fermentagäo como CHA e ácidos orgânicos (variáveis gúmicas) dificultando assim, as interpretacies e as extrapolacós dos resultados.

Portanto, essa diferenca demasiadamente elevada nos teores de nitrato na solugáo do solo dos perfis NA2 e NB1, como também do NA3 poderá ser expl icada convincentemente apoiada en pesquisas especificas sobre a biomassa microbiana desses solos.

As médias por perfil dos teores do ion nitrato poden ser apresentadas na seguinte ordem decresecente de selus valores:

$$
\begin{aligned}
\text { - perfil NAZ } & =4.770 .70 \mathrm{mg} / \mathrm{l} \\
\text { - perfil NAI } & =199.01 \mathrm{mg} / \mathrm{l} \\
\text { - perfil. NA3 } & =\quad 6.14 \mathrm{mg} / \mathrm{l} \\
\text { - perfil NBI } & =4.0 \mathrm{mg} / \mathrm{l}
\end{aligned}
$$

\section{Nitrito}

A figura 39 apresenta os teores médios, en profundidade, do ion nitrito na solugáo do solo extraida das amostras de solo e arena dos perfis anal isados. Percebe-se que seus teores säo bem menores em relacáo aos teores observados para o nitrato, como também, nao sao observas dma homogeneiaje entre os perfis analisados, quanto aos seus teores distribuidos en 


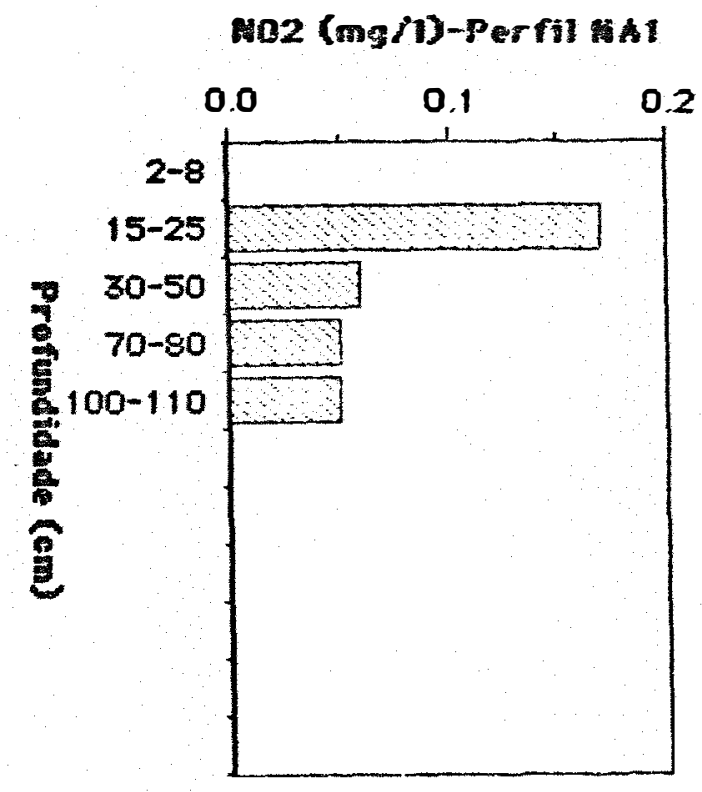

NO2 (mg/1)-Perfil AA2
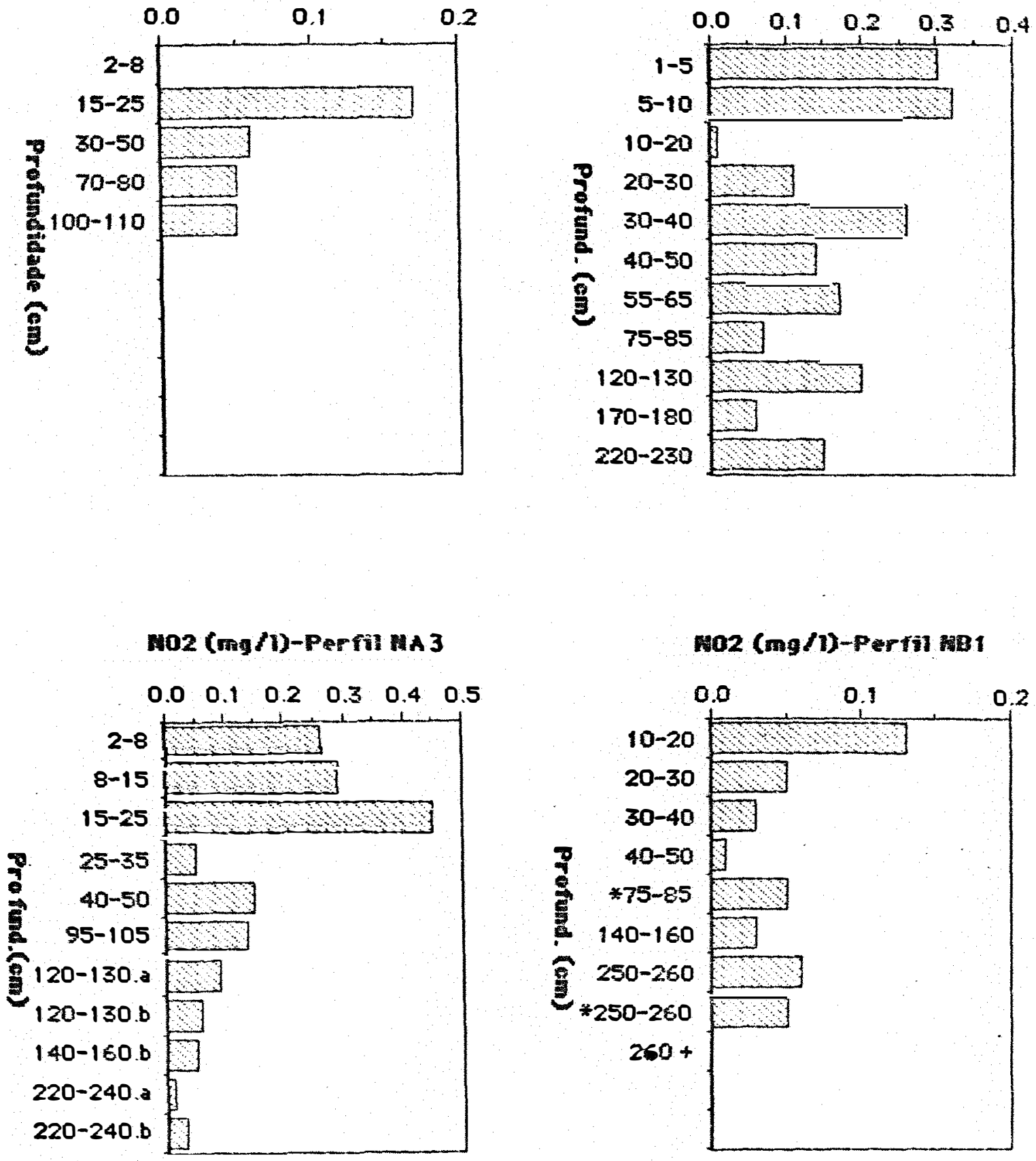

\section{W02 (mg/1)-Pertin nB1}

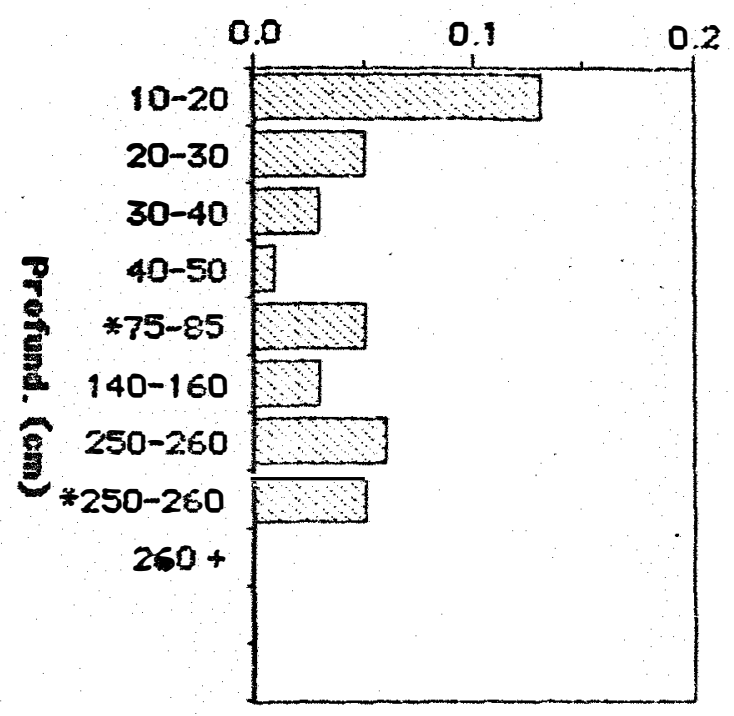

Figura 39 - Distribuizán em profundidade dos teores oe nitrito na solucäo extraida das amostras de solo e arena dos perfis analisados. 
profundidade. A tendência observada no perfil NA3 um incremento dos seus teores até a protundidade de: $15-25$ cone, a partir dai, verifica-se un decréscino gradativo para teores minimos até a profundidade de $220-240 \mathrm{~cm}$. Entretanto, no perfil NBI, percebe-se que a maior concentrafäo se localiza na camada superficial, seguido pelo decréscimo gradativo até a profundidade de $40-50$ cm, e a partir daí, un acréscimo pequeno, até a. profundidade observada. No perfil NAS observa-se uma irregularidade quanto a distributäo en profundidade, mas seus maiores teores säo encontrados na porcáo superficial do perfil. No perfil NA1 percebe-se a tendência de decréscimo dos seus teores em profundidade, mas por falta de amostra da camada superficial näo foi possivel determinar o seu teor e a sua interpretacăo.

As médias por perfil, dos teores do ion nitrito poden ser apresentadas na seguinte ordem decrescente de seus valores:

$$
\begin{aligned}
& \text { - perfil NA2 }=0.16 \mathrm{mg} / \mathrm{l} \\
& \text { - perfil NA3 }=0.14 \mathrm{mg} / \mathrm{l} \\
& \text { - perfil NA1 }=0.08 \mathrm{mg} / 1 \\
& \text { - perfil NB1 }=0.04 \mathrm{mg} / \mathrm{l}
\end{aligned}
$$

\section{Anis 10}

A distribuicäo en profundidade

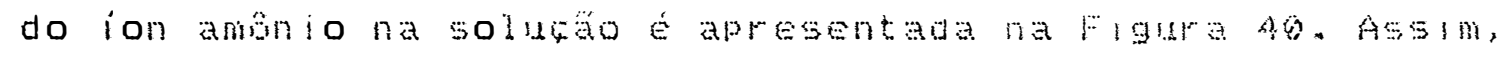
através do perfil NA3 e NB1 percebe-se que os maiores teores de aminio na solugáo do solo ocorrem na poražo 

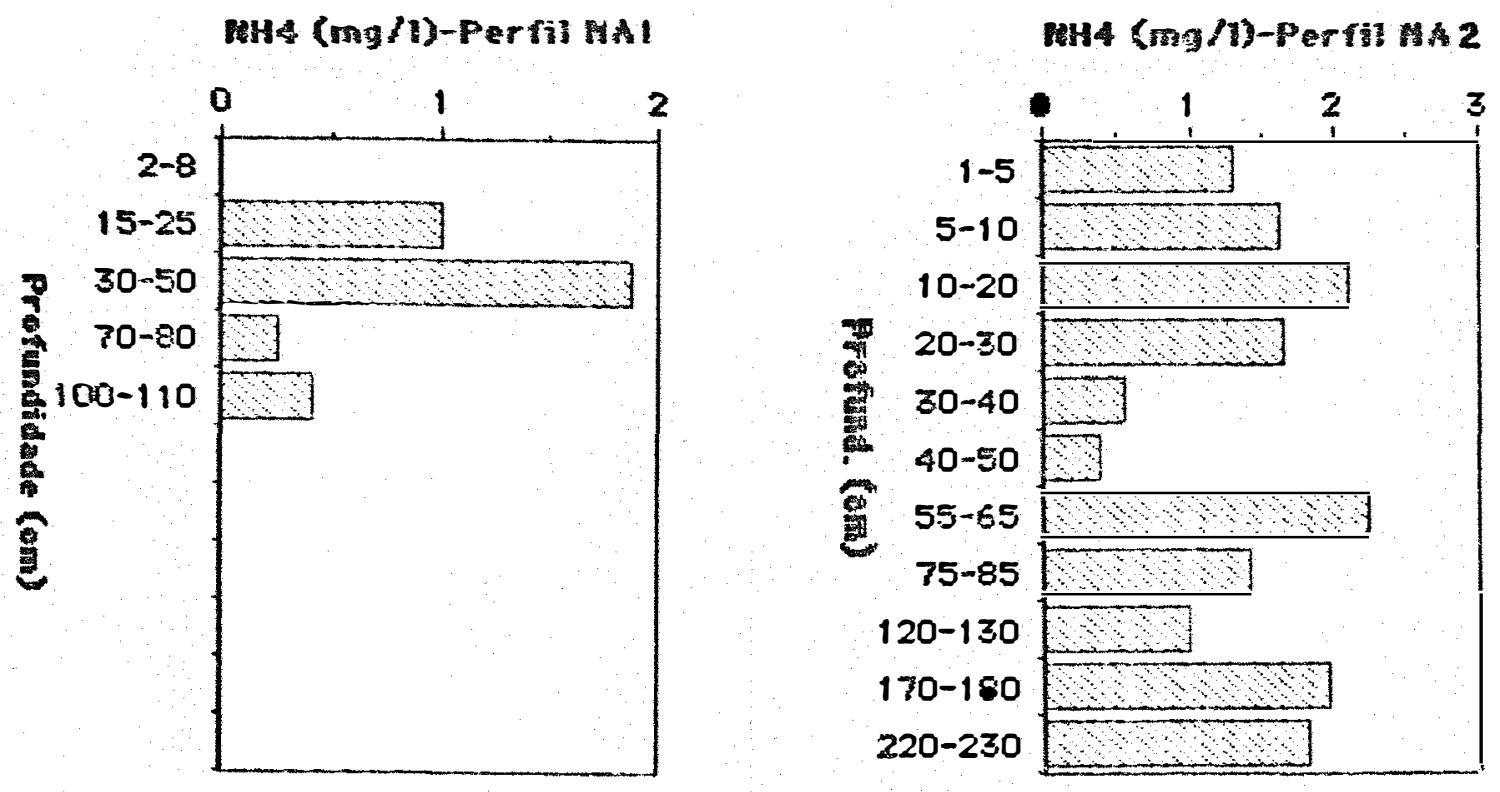

\section{คH4 (ng (1)-Perfin 3}

\section{MH4 (mg/r)-Pertil MB)}
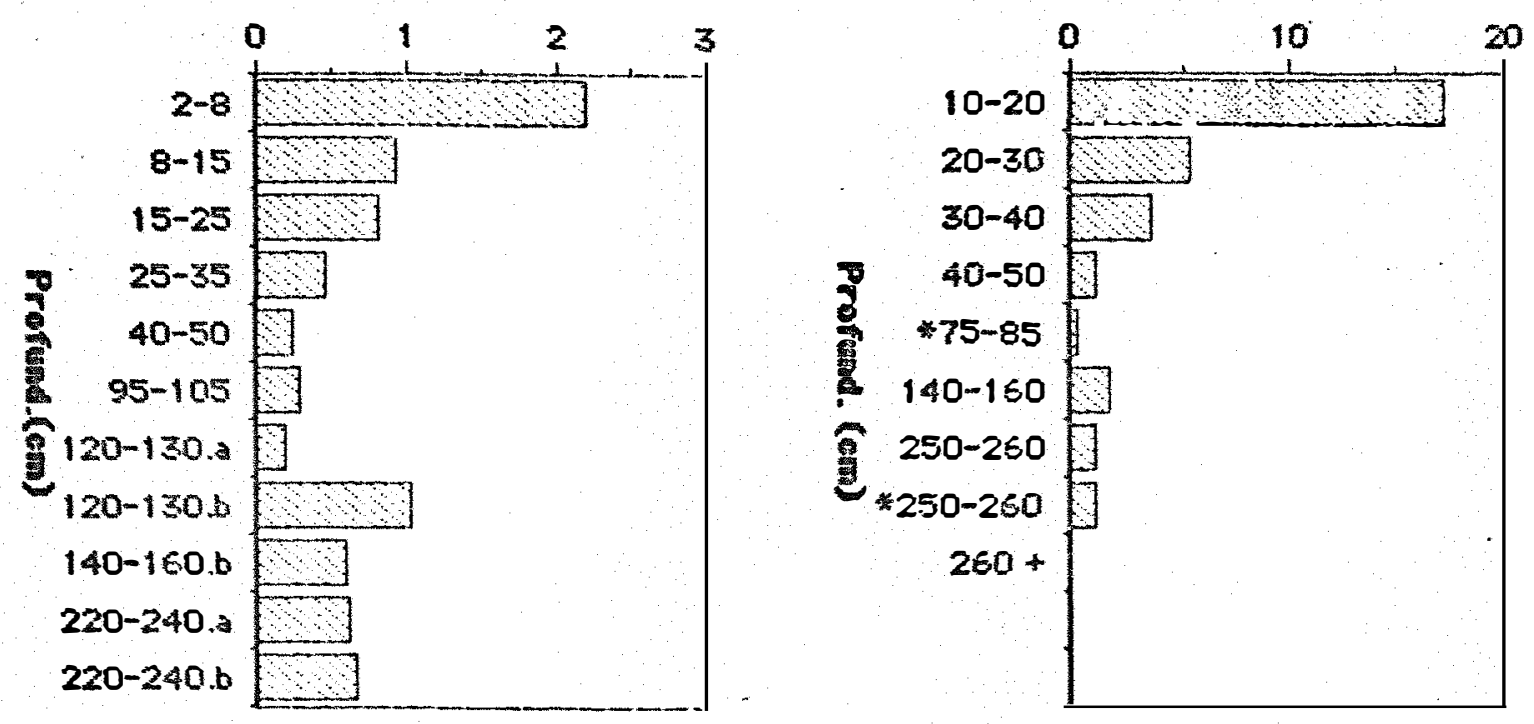

Figura 40 - Distribulä́o en profundidade dos teores oe:

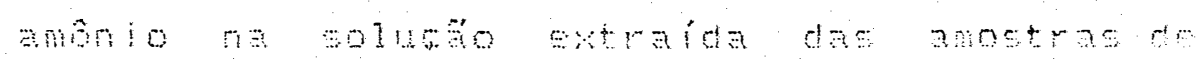
solo e arena dos perfis analisados. 
superficial do solo com valores de $2.18 \mathrm{mg} / 1$ no perfil NA3 e de $17.16 \mathrm{mg} / 1$ no perfil NB1. A tendência observada nestes dois perfis é que a distributía dos seus teores na solugáo do solo tende a decrescer en profundidade, com un leve acréscimo nas camadas onde há o predominio das arenas graniticas.

$$
\text { Ds teores mais elevados do }
$$

amônio. na porfáo superficial do solo sáo decorrentes da forte atividade microbiana na mineralizacáo da matéria orgânica depositada constantemente pela floresta.

Com relagáo aos pertis NA1 e NA2 percebe-se que a distribuigáo dos seus teores se processa de maneira irregular.

A média por perfil dos teores de amôn io poden ser assim resumidas:

$$
\begin{aligned}
& \text { - perfil NAI }=0.89 \mathrm{mg} / 1 \\
& \text { - perfil NA2 }=1.45 \mathrm{mg} / \mathrm{l} \\
& \text { - perfil NA3 }=0.73 \mathrm{mg} / \mathrm{l} \\
& \text { - perfil NB1 }=3.93 \mathrm{mg} / \mathrm{l} \\
& \text { Atraves das suas medias por }
\end{aligned}
$$

perfil, percebe-se que as diferengas sto demasiadamente elevadas quando se compara com as médias do ion nitrato. Tal fato ocorre porque, segundo RAIJ (1981), en condisies de boa aerafä́ e pH näo muito baixo, o amônio é rapidanente convertido em nitrato.

\section{Sulfato}

A figura 41 ilustra a



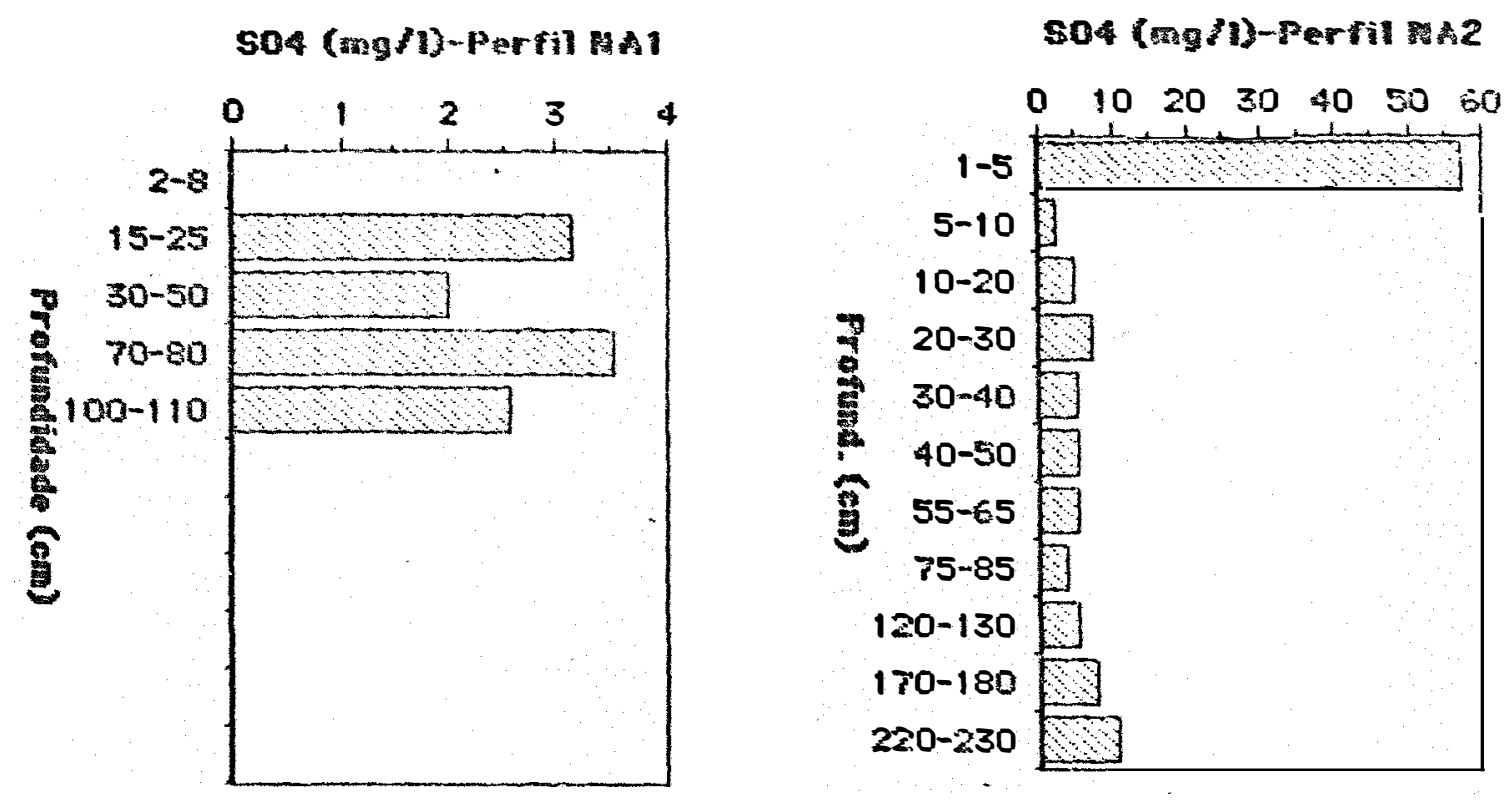

\section{SO4 (mg/D)-Pertin RA3}
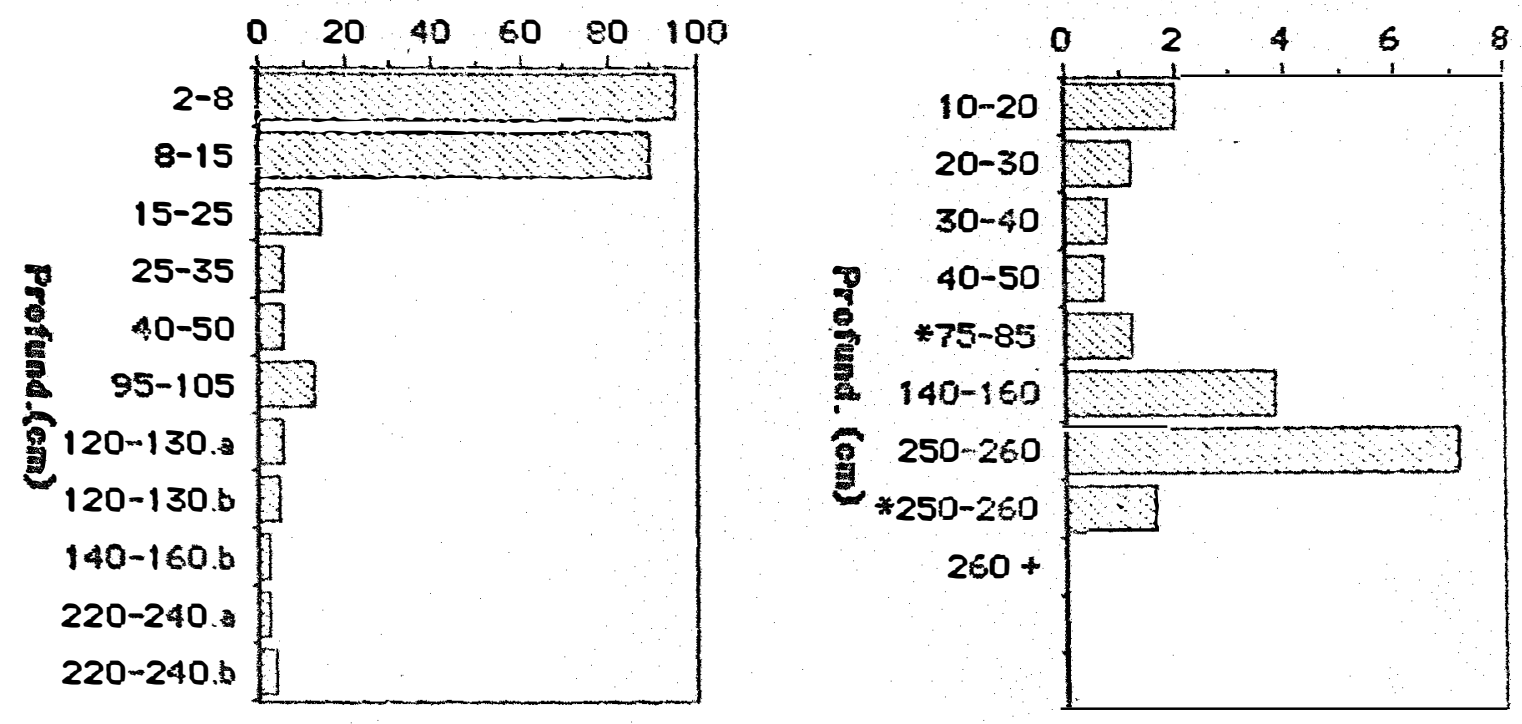

Figura 41 - Distribuba em profundidade dos teores de sulfato na solucäo extraida das amostras de

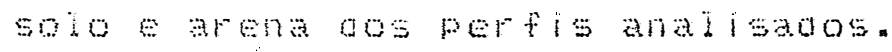


distribuitáo en profundidade, dos teores do ion sulfato na solucấo do solo dos pertis analisados. Percebe-se nos perfis NA2 E NA3 que os seus teores se concentran na porcấ superficial desses solose, decrescen de maneira abriptica para teores minimos a partir da canada $5-10$ cm de profundidade do perfil NA2 e, da camada $15-25$ cm de profundidade do perfil NA3. Os teores do ion sulfato das camadas superficiais dos perfis NA2 e NA3 diferen pouco, assin como, entre os perfis NA3 $E$ NB1 mas os mesmos apresentam niveis ben inferiores aos dos perfis NAz e NA3.

0 seu teor naikimo de $95,2 \mathrm{mg} / \mathrm{l}$

foi verificado na camada superficial de $2-8$ co de protundidade do perfil NA3, seguido pelo valor de 0,89 mg/l na camada de 8-is cm de profundidade do mesmo perfil. As médias por perfil, dos teores de sulfato poden ser assin resunidas:

$$
\begin{aligned}
& \text { - perfil NA1 }=2.81 \mathrm{mg} / \mathrm{l} \\
& \text { - Perfil NA2 =10,47 } \mathrm{mg} / \mathrm{l} \\
& \text { - perfil NA3 }=21,86 \mathrm{mg} / \mathrm{l} \\
& \text { - perfil NBI = 2.32 ng/l }
\end{aligned}
$$

Através dessas médias percebe-se claramente a sua remocáo no sentido descendente da encosta, conforme se percebe na topossequencia $N A$, cujo teor médio é verificado no perfil NA1, localizado na parte mais elevada da vertente, seguido pelo perfil NAz, posteriormente pelo perfil NA3, localizado na parte mais baika dessa 
topossequência estudada. 0 sulfato da solucáo do solo, segundo VITTI (1988) além de ser a forma prontamente absorvida pelas raizes, é também facilmente perdida por lixiviagáo. Estudos realizados en lisimetros por JORDAN \& ENSMINGER (1958), citados por VITTI (1988) mostram que o enxotre removido nas águas de drenagem era de 3 a 6 vezes maior do que o removido pelas colheitas.

Por outro lado, RAMPER \& ZEHLER (1967), citados por VITTI (1988), afirmam que o sulfato adsorvido pelos colóides do solo (constituidos por bidos de ferroe aluminio eargilas $1: 1$ ) é a principal fonte de reserva para as plantas, pois além de estar protegida das perdas por lixiviagáo, tal adsorqáo émuito fraca, podendo. - ion sulfato passar facilmente para a solucáo do solo e ser absorvido pelas raizes das plantas.

No perfil NB1 perceberse uma tendência acentuada com relacáo ao acréscimo dos teores de sultato en profundidade conforme se verifica na profundidade de $250-260 \mathrm{~cm}$, indicando a lixiviagáo $e$ o acumulo deste ion nas camadas mais profundas. REISENAUER et ali i (1973), citados por VITTI (1988) afirman que o sulfato tende a ser lixiviado para as camadas do sub-solo, as qua is apresentam maior forga de retengáo do mesmo. Por sua VEz KINJO (1980), citado por VITTI (1988), afirma que a adsorgáo do sulfato, en solos tropicais, tende a ser maior com o aumento da profundidade ao longo do perfil, devido aos valores do PCZ do horizonte B serem maiores em relacáo ao do horizonte $A$, sugerindo o efeito da matéria orgânica 
no abaixamento do mesmo. CHAD et ali i (1962), BIN(HHAM et ali $i$ (1965) afirman que o sulfato adsorvido está en equilibrio com o sulfato en solucăo e pode ser trocado por outros ânions de maior habilidade de coordenacăo, de acordo com a série: hidrowila > fosfato> molibdato> sulfato $=$ acetato $>$ nitrato $=$ cloreto. Analisando esta série deduz-se que, especialmente o fosfato tende a promover desoraäo do sulfato, o que determina o aunento de perdas por lixiviagäo.

\section{Cloreto}

A distribuicăo en profundidade do ion cloreto na solucäo do solo está representada na figura 47. Percebe-se que os perfis NA2 e NA3 apresenta "naiores concentracües do cloreto na porcäo superficial desses solos, seguido por um declinio gradativo em profundidade (perfil NA3). No perfil NA2, após o declinio, verifica-se un leve acréscimo nas profundidades de $120 \cdots 130$ e $1.70-180 \mathrm{~cm}$

Apesar da falta de dados no perfil NBd. até a profundidade de $40 . \mathrm{cm}$, verifica-se que trá una tendência de increnento em profundidade dos teores do ion cloreto na solucäo do solo a exemplo do que ocorre no perfil NA2.

As médias por perfil, dos teores do ion cloreto podem ser aqui resunidas:

- perfil NAI $=16,59 \mathrm{mg} / 1$
- perfil NA2 $=17,31 \mathrm{mg} / \mathrm{l}$ 

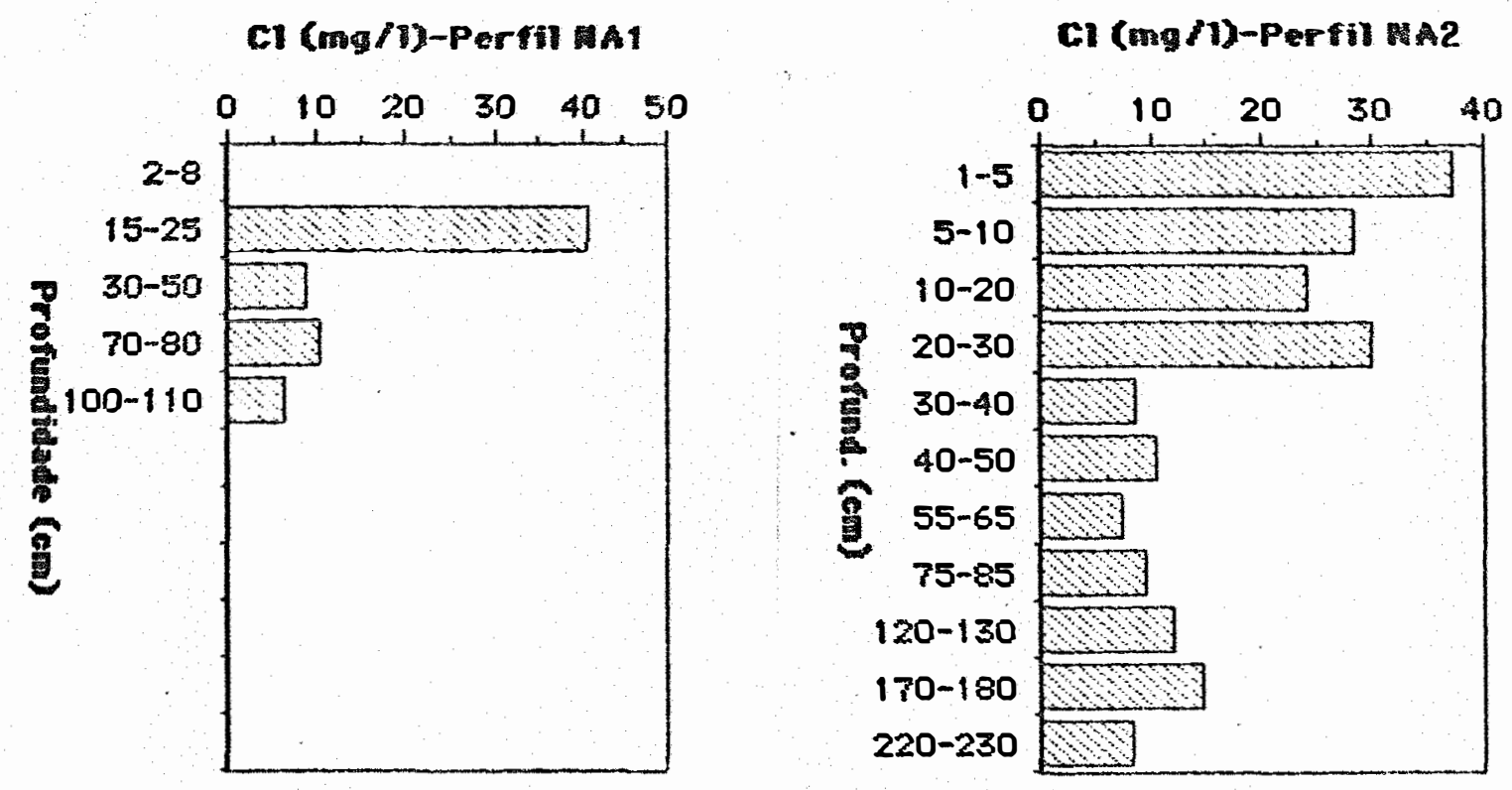

C) (mg/D)-Parfil HA3
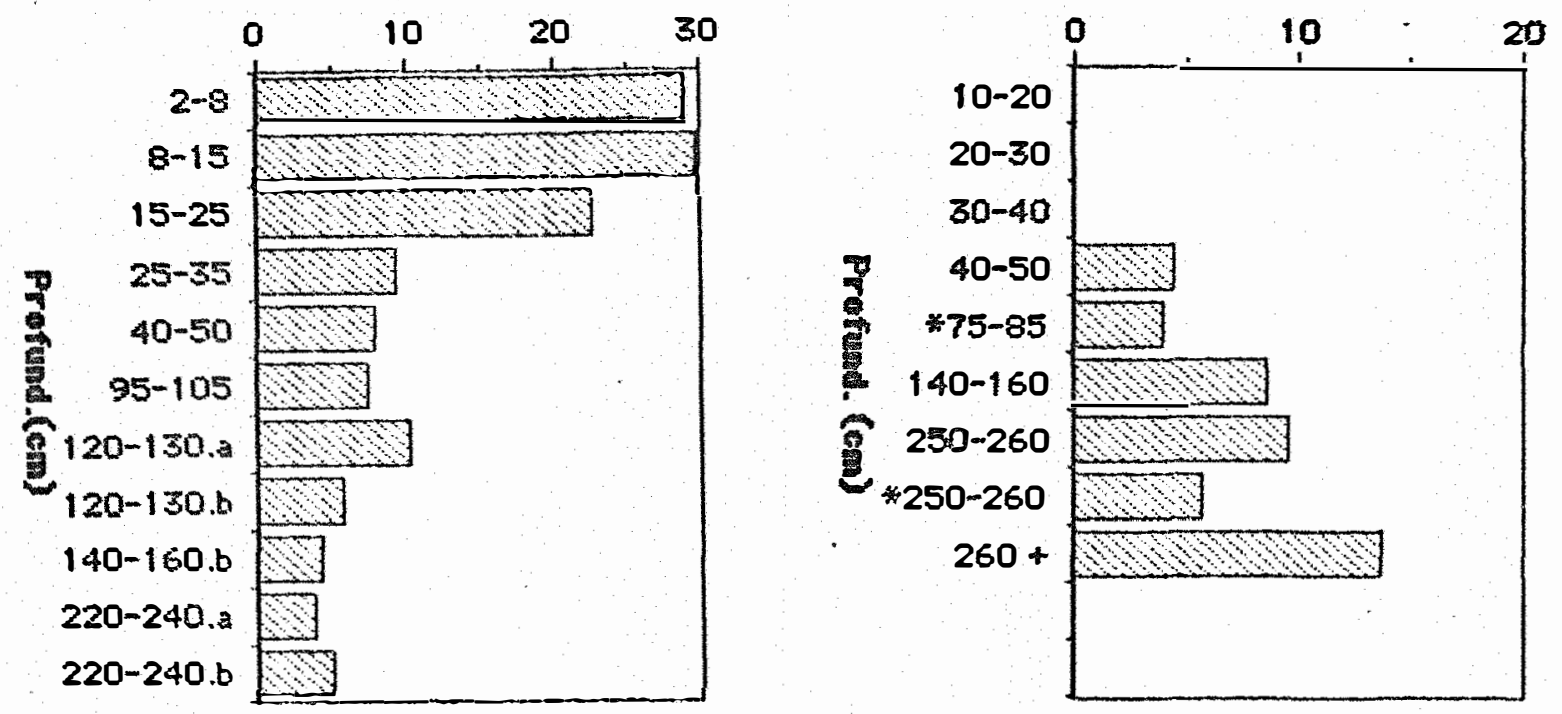

Figura 42 - Distribuica em profundidade dos teores de cloreto na solucáo extraida das amostras de solo e arena dos perfis anal isados. 
- perfil NA3 $=12,31 \mathrm{mg} / \mathrm{l}$
- pertil NB1 $=7,63 \mathrm{mg} / \mathrm{l}$

\section{Silíclo}

Analisando a solusáo do solo obtida das amostras de solo e arena dos perfis NAs, NAz, NA3 e NB1, obteve-se a distribuicăo em profundidade, dos seus teores em silicio apresentados na Figura 43 . Percebese através da mesma, que o perfil Naz apresenta na sua camada superficial, teor mais elevado de silicio, seguindo por um declinio suave até atingir o teor de $0.97 \mathrm{mg} / \mathrm{l}$ na profundidade de $10-20 \mathrm{~cm} e$, a partir dai, manteve--.se pouco alterado, mas com uma tendência de leve incremento nas camadas onde há o predominio da arena granitica amarelada.

No perfil NB1, a mesma tendência é observada $e$, isto acontece porque segundo MELFI \& CERRI (197A), a silica liberada na hidroilise dos feldspatos permanece parcialmente retida no perfil, quer entrando na constituicáo de produtos amorfos, quer formando os minerais do grupo da caolinita, considerando também que a remocáo da silica combinada é moderada, pois at inge valores máximos en torno de $50 \%$ nos hor izontes sobrejacentes da arena.

As médias por perfil dos teores de silicio sấ apresentadas a seguir:

$$
\begin{aligned}
& \text { - perfil NAl }=0,98 \mathrm{mg} / \mathrm{l} \\
& \text { - perfil NAE }=1,08 \mathrm{mg} / \mathrm{l} \\
& \text { - perfil NA3 }=4,70 \mathrm{mg} / \mathrm{l} \\
& \text { - perfil NBI }=1,20 \mathrm{mg} / \mathrm{l}
\end{aligned}
$$


Si (mol)-Pertil nA1

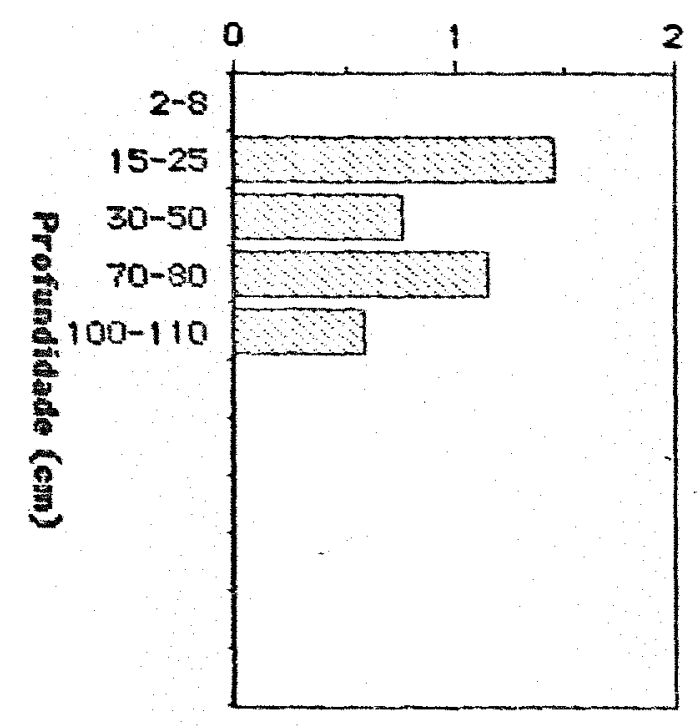

Si (ma) - Pern 3

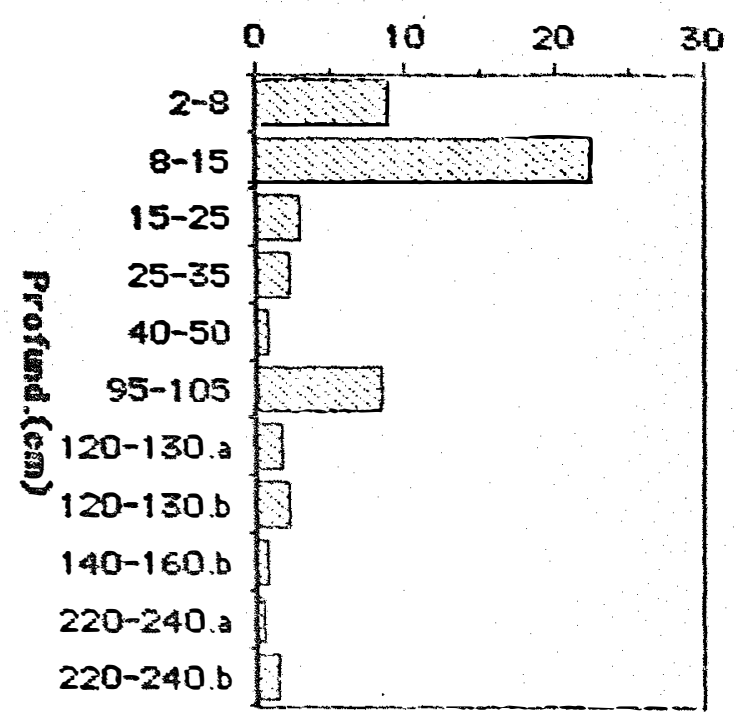

Si (mof)-Perfin h 2

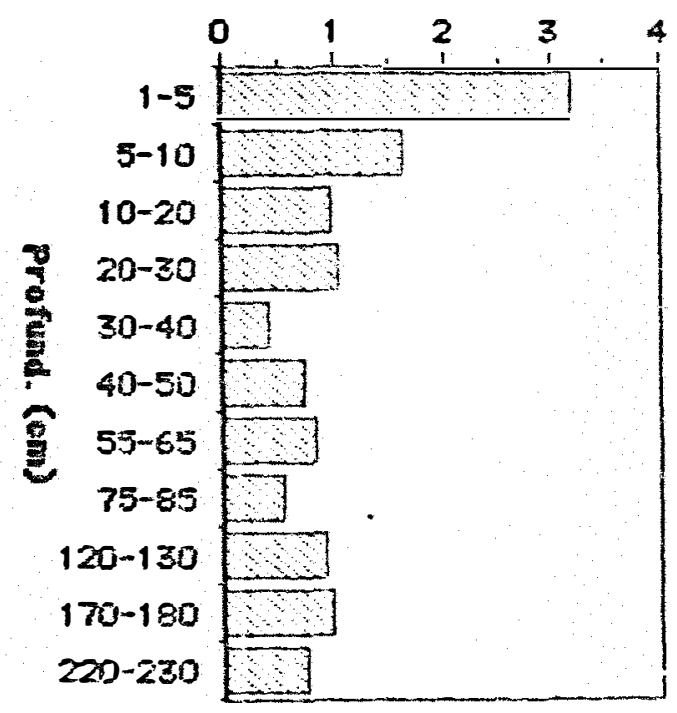

Si (mofi)-Forfil ws:

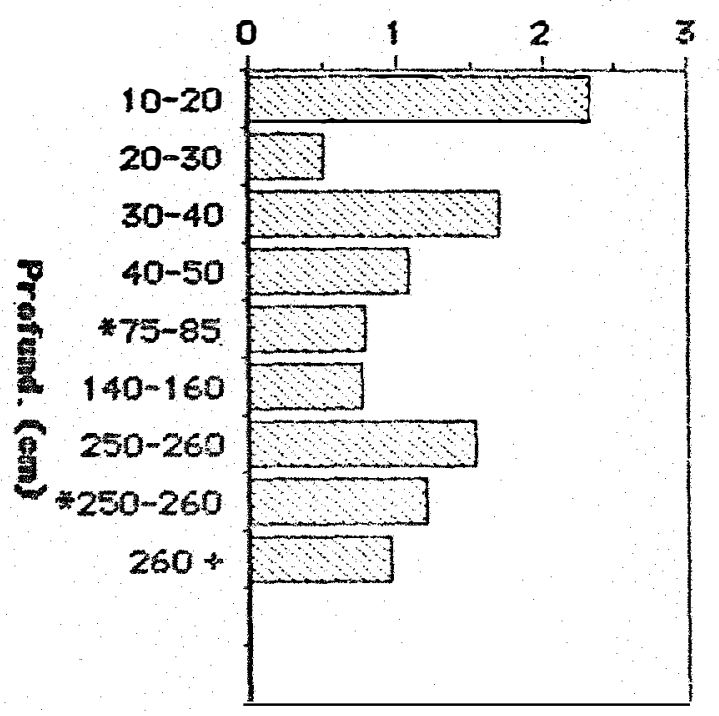

Figura 43 - Distribuigso en profundidade dos teores de silicio na solucáo extraida das amostras de solo e arena dos perfis anal isodos. 
Essas medias estéco ben abaiko da média de 20.1 pan de sioe soluvel cextraido em água destilada), determinado por RAIJ \& CAMARGO (1973), para solos do Estado de Sä́o Pallo. Entretanto, esses mesmos autores afirman que o teor de silica solivel extraída dos solos varia bastante com os metodos de anilise, sendo importante os fatores tempo de contato e relacáo do volune de solugáo extraida para peso de solo, ben como o tipo de solucăo ut ilizada.

Analisando a média do teor de silicio dos perfis que se localizam na vertente $N A$, percebe-se claramente que a mesma aunenta no sentido descendente da vertente, ou seja, o perfil NA1, localizado na parte nais elevada da vertente, apresenta a média 9.9 mg/l de silicio, seguida pela média do perfil NA3 ent a.y $m g / l$ e tal fato evidencia o proeesso do fluxo lateral do silicio nesta vertente.

MONIZ Et ali i (1982) corrobora com esses resultados, afirmando que, dependendo da natureza mineralígica do material de origem e da rocha subjacente, os ions ferro, manganes e silicio e as bases se concentram na baika vertente como resultado da acäo do fluko lateral da água.

\section{sódio}

A Figura 44 apresenta a distribuiga em profundidade dos teores de sódo na solucao do solo. Nos perfis NA1 E NB1, percebe-se que os maiores 


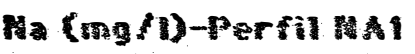

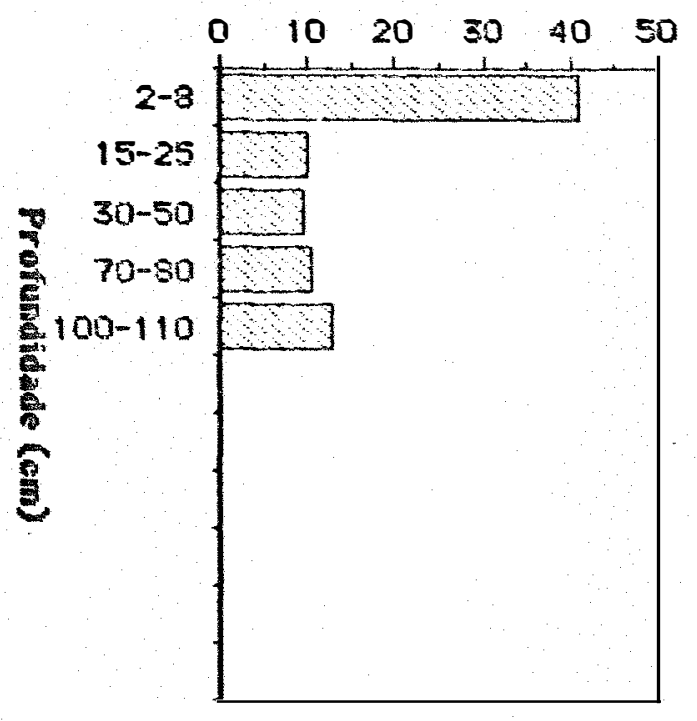

Na (mgli)-Perfil ?A3

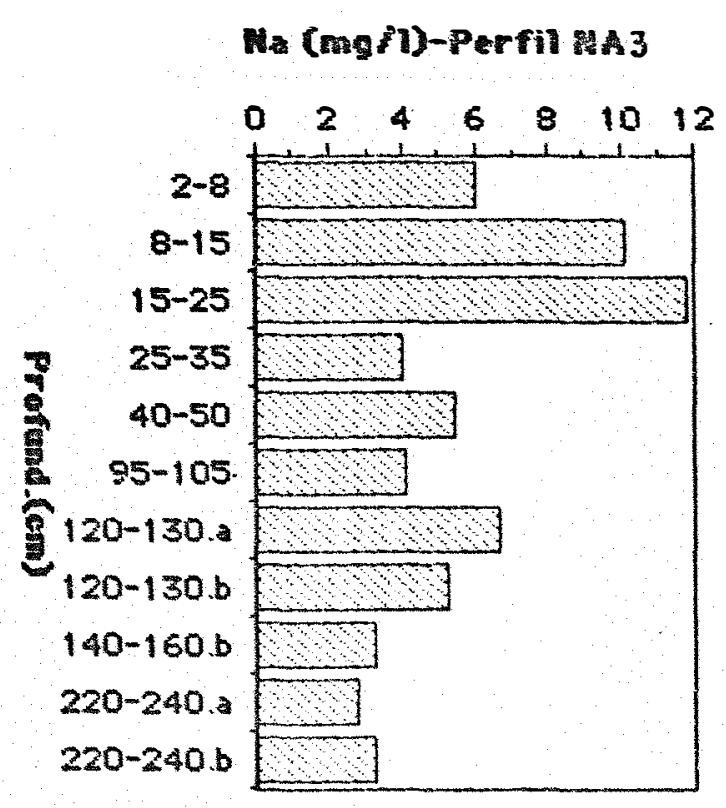

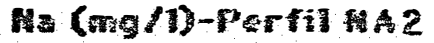

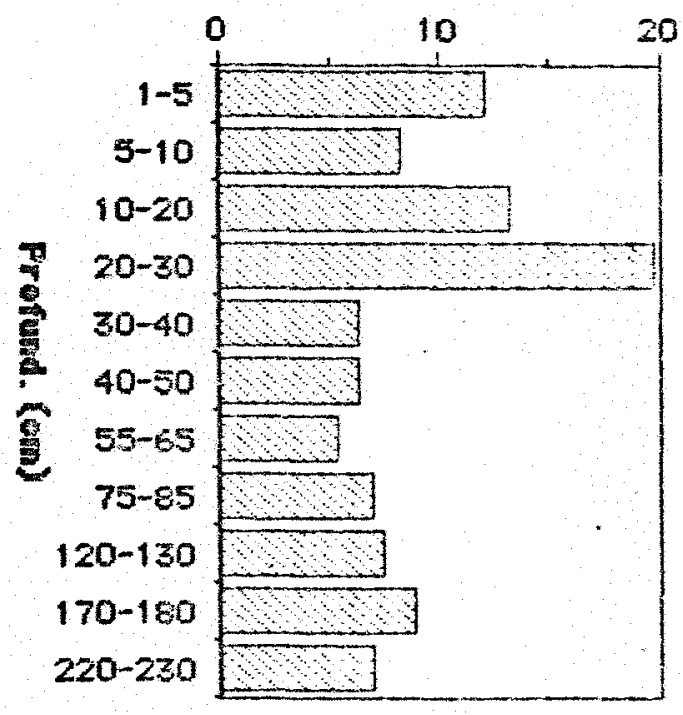

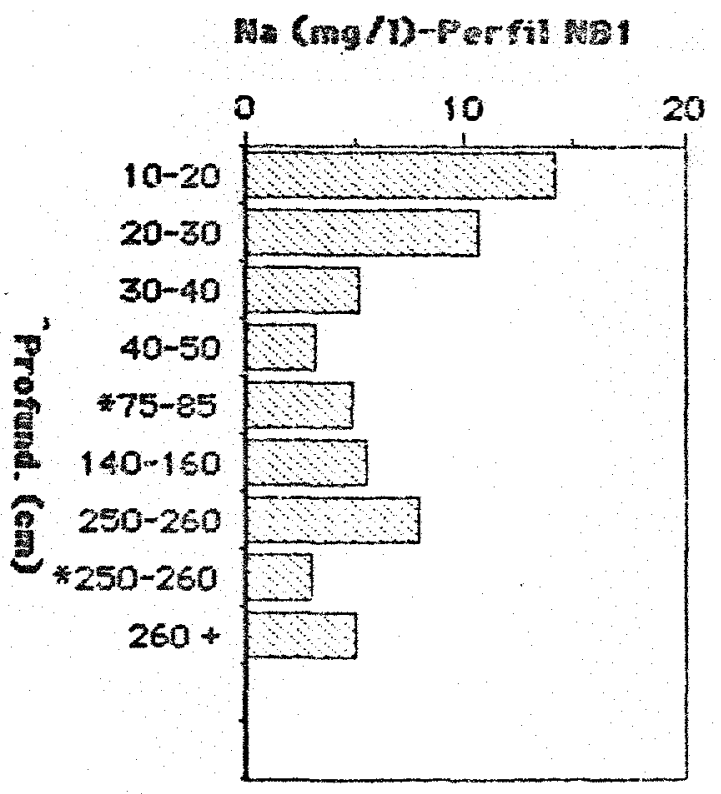

Figura 4a-Distribuico em profundidade dos teores de sidio na soluse extrate das amostras de 5010 serena dos pertis analisados. 
teores de sódio na solucäo do solo ocorre na camada superficial, con valores de $41.04 \mathrm{mg} / \mathrm{l}$ no pertil NÁ e 14.2 mg/l no perfil NB1. A tendência observada no perfil NAs, é un declínio abruptico dos seus teores na solucäo do solo a partir da camada de $15-25$ cm de profundidade. Ja no perfil NB1 os seus teores declinam lentamente até a canada de: 4050 cn de profundidade, seguindo de un incremento até as camadas onde há o predominio da arena granitica avermelhada. A tendencia observada nos perfis NA2 e NA3 É pelo incremento en profundidade, até as camadas de $20-30 \mathrm{~cm}$ de profundidade no perfil NA2 e na camada de $15-25 \mathrm{~cm}$ de profundidade do perfil NA3, seguido de un declinio abriptico e incrementos irregulares até a profundidade observada.

As variafís observadas nos teores do ion sódio na solugáo do solo näo apresentan nentuna correlacăo con as variacígs nos teores de sídio trocável analisado na fase solida desses mesmos solos. As médias por perfil, dos teores de sódio sáo apresentadas a seguir de maneira resumida:

$$
\begin{aligned}
& \text { - pertil NA1 }=16,71 \mathrm{mg} / \mathrm{l} \\
& \text { - perfil NA2 }=9,25 \mathrm{mg} / \mathrm{l} \\
& \text { - perfil NA3 }=0,73 \mathrm{mg} / 1 \\
& \text { - perfil NB1 }=6,64 \mathrm{mg} / \mathrm{l}
\end{aligned}
$$

A partir dessas médias por perfil percebe-se facilmente a dinânica do ion sodio na topossequência NA, ou seja, o perfil NAI que é constituido 
por um solo ainda jovem (solo Cambissolo pouco evoluido) apresenta a média de $16,71 \mathrm{mg} / \mathrm{l}$ de sódio na solutấo do solo, seguido, na ordem decrescente do seu teor e na ordem descendente da topossequencia pela nédia do perfil Naz de 9.25 ng/l e, por liltimo a média do perfil NA3 de $0,73 \mathrm{mg} / \mathrm{l}$, demonstrando desta maneira que o perfil NA1, ainda detén grande parte do sudio proveniente da hidrilise do plagioclásio. Já no caso do pérfil NA2, que é constituido por un solo Cambissolo un pouco mais evoluito em relacáo ao solo do perfil NA1, percebe-se que os teores de södio decrescem bastante e a mesma tendência de decréscimo é observada no perfil NA3 que é também constituido por un solo Cambissolo e se localiza na parte mais baika da vertente estudada, evidenciando desta maneira que a remocáo do sodio foi acentuada nesses dois ultimos perfis, pelo fato de constituirem solos mais evoluidos. Este comportamento observado concorda com a série liotrórica, a qual estabelece que o sidio é o cation retido pelo solo com menor energia. En relacáo ao potássio, magnésio e cálcio MALAVOLTA (1976) afirma que o sódio é o cátion adsorvido pelos coldides do solo com menor energia, como também, năo toma parte da formaço das argilas minerais como o potassio e o magnésio. O sidio é portanto, sujeito a grandesperdas por lixiviacăo e se acumula nas águas do mar, enquanto os materiais de decomposicáo do solo, tornam-se pobres no elemento. MELFI \& CERRI ( 1974 ) afirman que o sódio proveniente da hidrólise do plagioclásio, é praticamente eliminado do perfil, jà nas primeiras etapas de 
meteorizacão do granito.

\section{Potássio}

A distribuiğón en profundidada dos teores de potássio na soluc ấa do solo, é apresentada na Figura 45. Percebe-se que os teores sấo bastantes elevados atingindo valores de até $110,50 \mathrm{mg} / 1$ na porqăo superficial do perfil NA1, seguindo pelo decréseimo en profundidade. É importante " ressaltar que essa mesma tendência é observada nos demais perfis analisados, inclusive no perfil NBi, que está localizado numa outra vertente, caracterizada como NB. O teor de potássio é mais elevado na porgäo superficial do solo, porque segundo MALAUOLTA (1976), o sels teor na matéria orgânica é mais ou menos da mesma orden de grandeza do teor de potásio trocável, E, os microorganismos do solo poden atuar na solubilizacão do potássio da matéria orgânica convertendoo en potássio solúvel. O mesmo autor atirma também, que os microorganismos poden provocar um fixacáo biológica ou incorporar o potássio em suas células, como também, o potássio pode sofrer fixacáo devido à alta capacidade cationica do hímus.

Em resumo, o ion potassio na solucấo do solo se destaca dos demais ions básicos, em funcáo da sua concentracáo na porcáo superficial do solo decorrente da mineralizacáo da matéria orgânica promovida pelos microorganismos do solo.

Os teores de potassio na solut ào 
K (mg/1)-Perfil nA

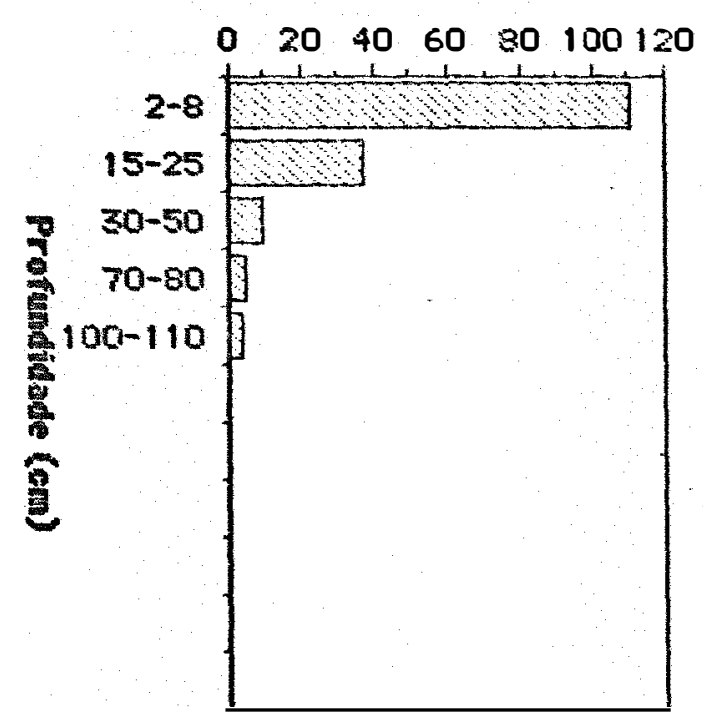

$K(\operatorname{mg} / 1)-\operatorname{Per} \operatorname{til}) 3$

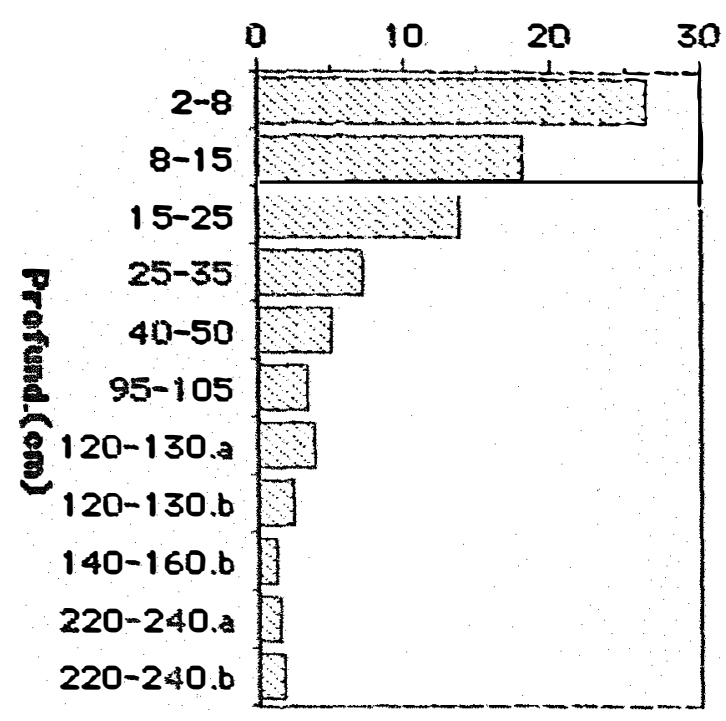

$K(\operatorname{mg} /)-P$ erfin $1 \mathrm{~A} 2$

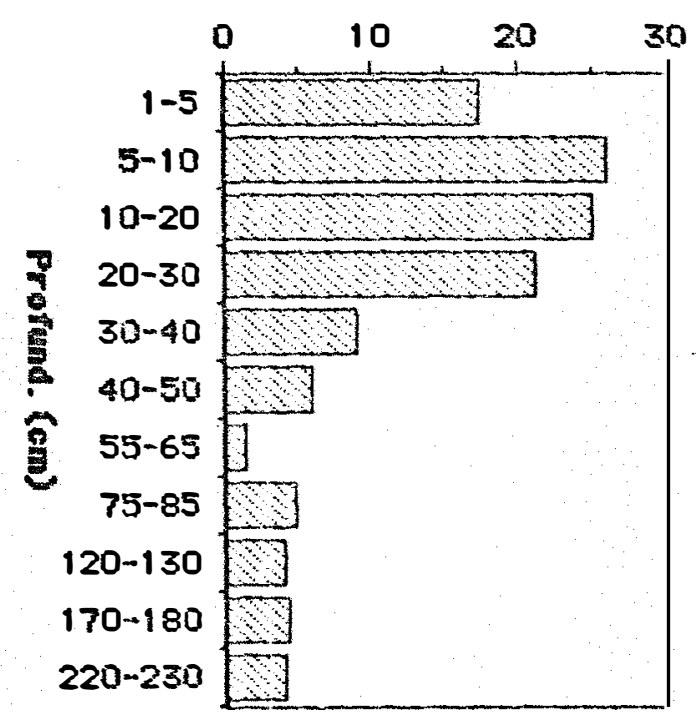

K (mg/1)-Parin

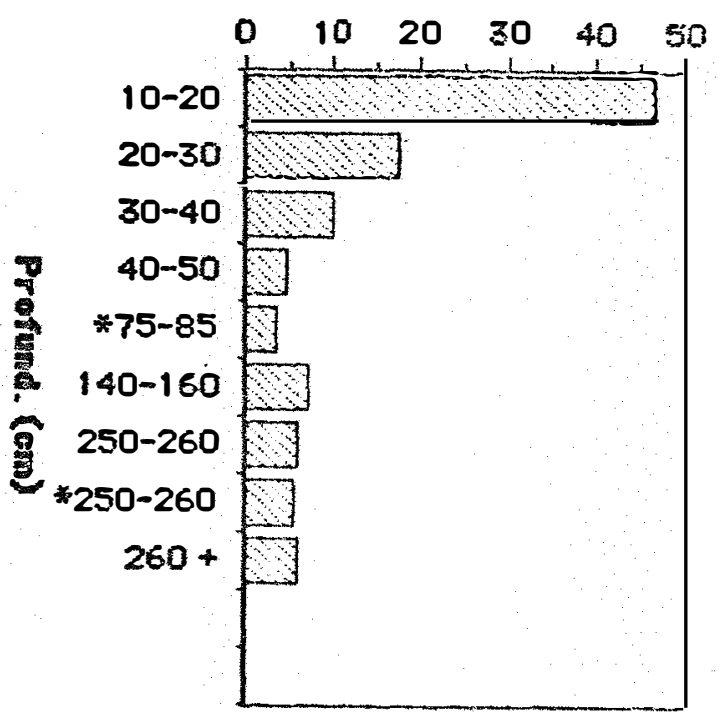

Figura 45 - Distribuicáo em profundidade dos teores de potássio na solucáo extraida das amostras de solo e arena dos perfis anal loados. 
do solo extraidas das amostras de solo e arena săo aqui representados em termos de média por perfil:

$$
\begin{aligned}
& \text { - perfil NAI }=32,81 \mathrm{mg} / \mathrm{l} \\
& \text { - perfil NA2 }=11,21 \mathrm{mg} / 1 \\
& \text { - perfil NA3 }=7,68 \mathrm{mg} / \mathrm{l} \\
& \text { - perfil NB1 }=1.1,86 \mathrm{mg} / 1 \\
& \text { Percebe-se gue essas médias }
\end{aligned}
$$

determinadas estäo bem acima da faixa de é-b ppm apresentada por MALAVOLTA (1876), sem contudo informar sobre o método utilizado na extrąáo da solucấo do solo. A ordem decrescente em termos de média do teor de potássio por perfil é a seguinte:

NA1 $(32,91 \mathrm{mg} / 1)>\operatorname{NAZ}(11,21 \mathrm{mg} / 1)>\mathrm{NA3}(7,68 \mathrm{mg} / 1)$ Essas médias refletem multo bem - gras de desenvolvimento de cada um desses perfis; ou seja, o perfil NAj qué constifido por um solo ainda poldco desenvolvido e localizado na parte mais elevacia da vertente, detem ainda na solugäo do solo, teores elevados de potássio originado do intemperismo dos feldspatos potassicos. Por outro lado, ocorre um declinio bem acentuado da sua concentracäo na solufáo do solo no sentido descendente da encosta, ou seja, para os perfis NA2 E NA3, refletindo gle esses dois perfis sấo mais evoluidos e mais lixiviados. As analises micromorfologitas e mineralógicas confirman esses aspectos. Ainda TARDY (1969) afirma que a dinâmica do potássio no solo, que é, em relacáo ao sidio ou ao conjunto dos outros cations 
básicos, muito mais liberado quando as solucbes säo diluidas, os climas dimidose as lessivagens energéticas. 0 potássio é soluvel da mesma maneira que o sódio, mas, nas arenas graniticas, ele é retido nos feldspatos potássicos menos alteráveis que os plagioclásios. Em meios ben drenados a alteracä́o dos feldspatos potásicos se acelera e isto tanto mais quando a temperatura se eleva. Desta maneira, en elinat tropical inido, todos os feldspatos sấo vigorosamente hidrolizados e os balancos dos alcalinos se aprowiman, mas, en clima temperado e também en clima árido eles se dispersam, tendo em vista que, as albitas se alteram e os feldspatos potásicos se conservam por mais tempo. Tambén MELFI \& CERRJ (1974) corroboran com os resultados obtidos, afirmando que a eliminacio do potassio do perfil de alteracáo é bem mais moderada en relacăo a eliminacäo do sódio, porén progressiva e está relacionada a alta estabilidade dos feldspatos potássicos. Dutro detalhe observado através das análises mineralógicas é que esses solos são constituidos dominantemente por argilas caoliniticas e segundo Malavolta $(1976)$, a capacidade de piragáo dos colbides constituidos pelas argilas do tipo 1:1, fikam poldco o potassio e por este motivo, os solos tropicais, em que a caolinita é dominante, fixam pouco o potássio.

\section{Cálc io}

A figura 46 apresenta a distribuicá em profundidade dos teores dos ions cálcio 

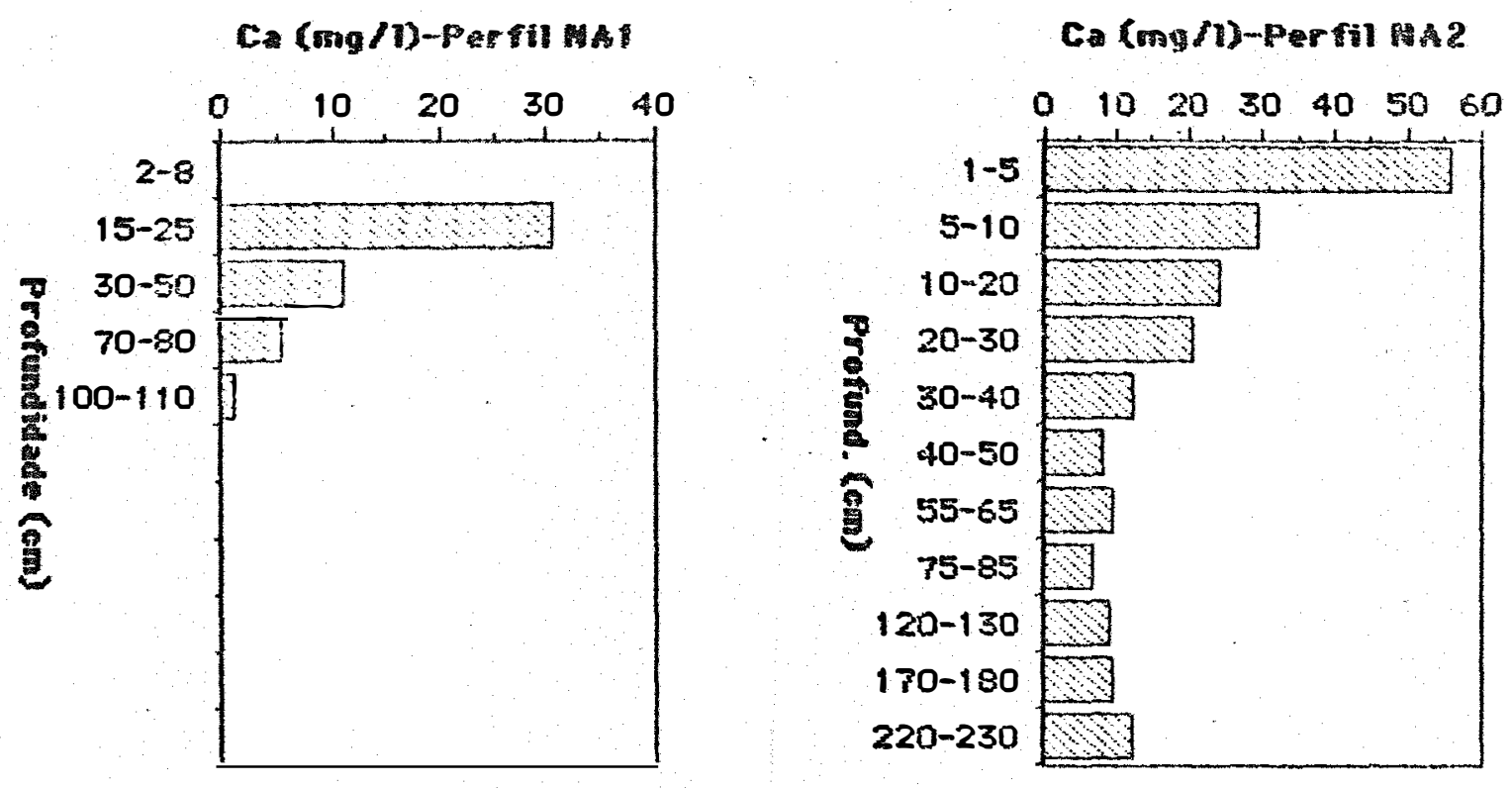

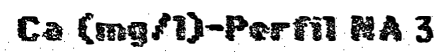

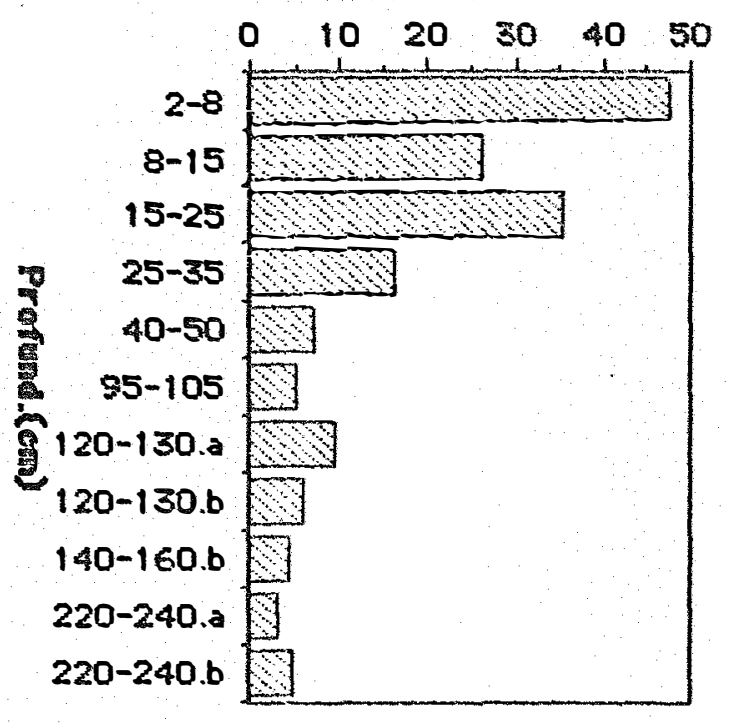

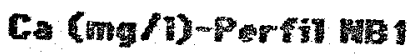

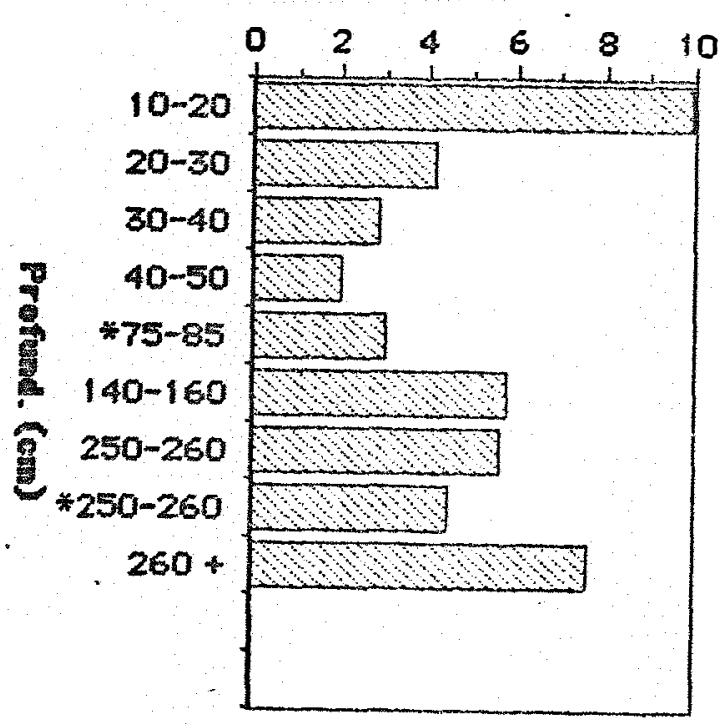

Figura to - Distribuica em profundidade dos teores de cálcio na solucáo extraida das amostras de solo e arena dos perfis anal isados. 
na solucäo do solo dos perfis analisados. Os seus teores såo elevados na solucăo do solo, atingindo valores de até $55,84 \mathrm{mg} / \mathrm{l}$ na portăo superficial do perfil NA2 e a tendência observada nos pertis NA1, NA? $E$ NA3 \& declinio en profundidade. 0 declinio dos seus teores observados no perfil NB1, ocorre até a protundidade de $40-$ 50 cm, seguindo. pelo incremento nas camadas onde hat o predominio das arenas graniticas avermelhadas. Nota- se uma leve tendencia para incremento dos seus teores nas camadas onde há o predomínio das arenas graniticas amareladas do perfil NA2.

Os seus maiores teores na porgäo superficial, säo provenientes da mineralizacăo da matéria orgânica constantemente depositada pela floresta, na - superficie desses solos.

Já no caso dos perfis NB1, o incremento do cálcio nas camadas das arenas graniticas se deve a hidrilise dos feldspatos liberando-o prontamente no complexo coloidal. Rosolem (1988) afirma que o calcio ocorre nos solos nas seguintes formas principais: carbonatos, silicatos, na matéria orgânica, na forma trocável e na solutäo do solo. o mesmo autor afirma que as diferentes formas de cálcio no solo se encontra em equilibrio, mas a sua dinâmica ainda näo é tão bem estudada como a do potássio.

As médias por perfil dos teores de cálcio na solukäo do solo, săo apresentadas a seguir:

- Perfil NA1 = 12, OA ng/l 


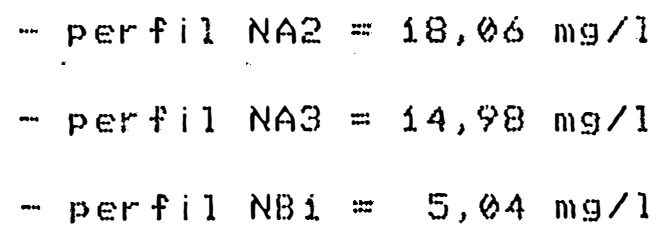

Apesar da pouca mobilidade do cálcio no solo, verifica-se através da sua média que há um actimulo desse ion nos perfis subsequentes ao pefil NA1, isto porque, os perfis NA2 e NA3 apresentam maiores teores de cálcio en relacáo ao perfil NA1.

\section{Magnésio}

A distributắo en profundidade dos teores do ion magnésio na solufáo do solo dos perfis anal isados, é apresentada na figura 47. Assim percebe-se, que o ion magnésio apresenta os maiores teores na porcáo superficial dos pertis analisados, com valores máximos de até $15,78 \mathrm{mg} / 1$ na camada de $4.5 \mathrm{~cm}$ de profundidade do perfil NAz. É importante observar que a tendencia verificada nos perfis NAs, NA2 E NA3 quanto à distribuiço em profundidade dos seus teores é bastante similar em relaço à do ion cálcio, inclusive quanto à do perfil NBI.

o maior teor de magnésio nat porcăo superficial do solo é decorrente da mineralizacáo da matér ia orgânica constantemente depositada pela vegetacáo.

No caso do perfil NBá, observa-se un ligeiro incremento no seu teor nas camadas onde há o predomínio da arena granitica avermelhada. Este teor mais elevado do magnésio provem de hidrílise dos feldspatos a inda presentes nessas arenas. 
Mg(mg/) -Perfil MA

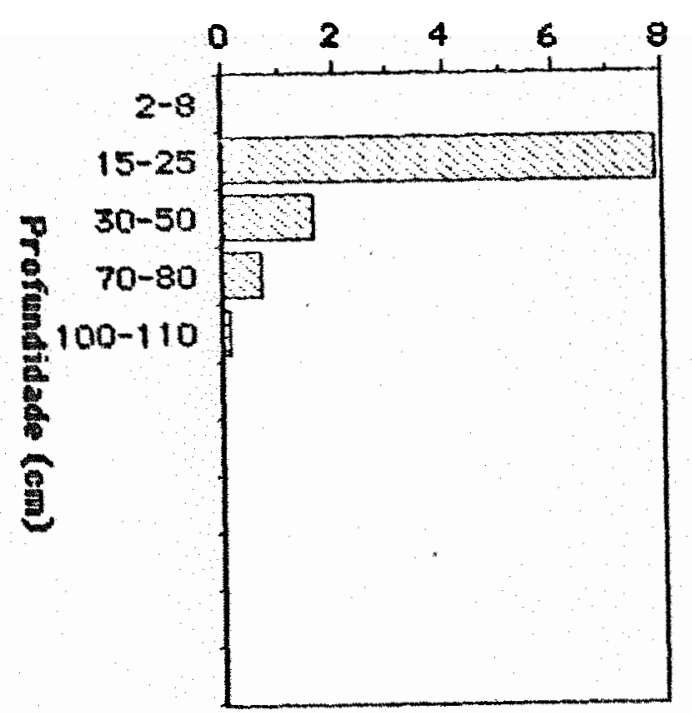

Mg (mgli)-Pertil Ha 3

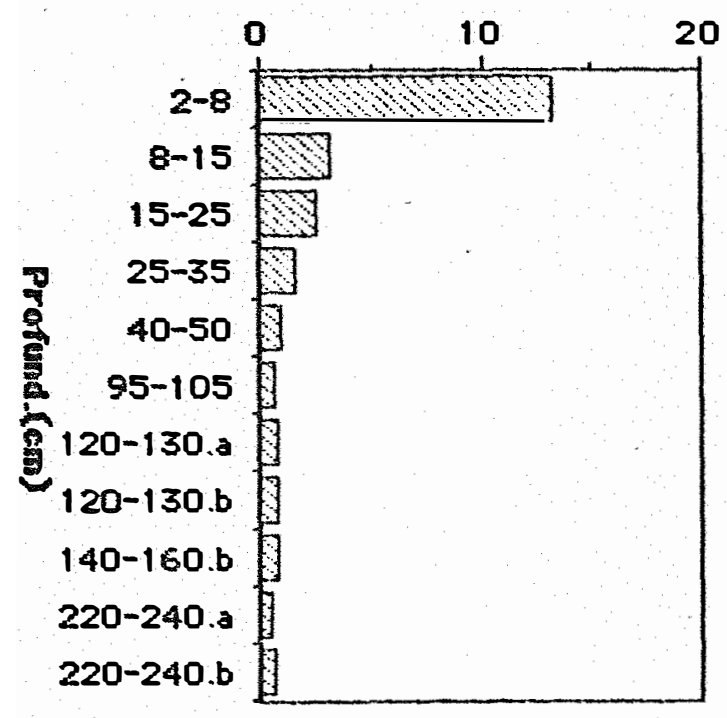

Mg (mg/b)-Perril nat

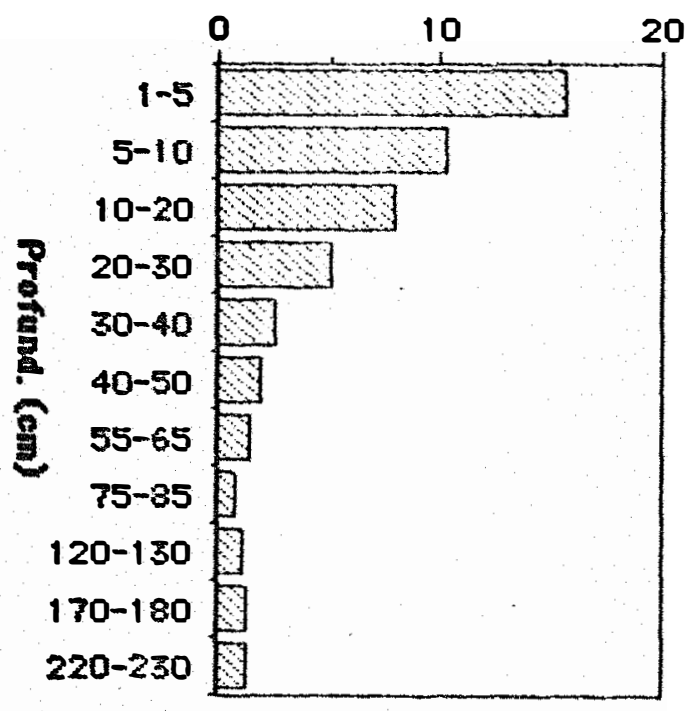

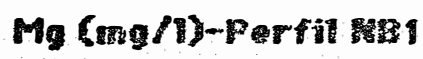

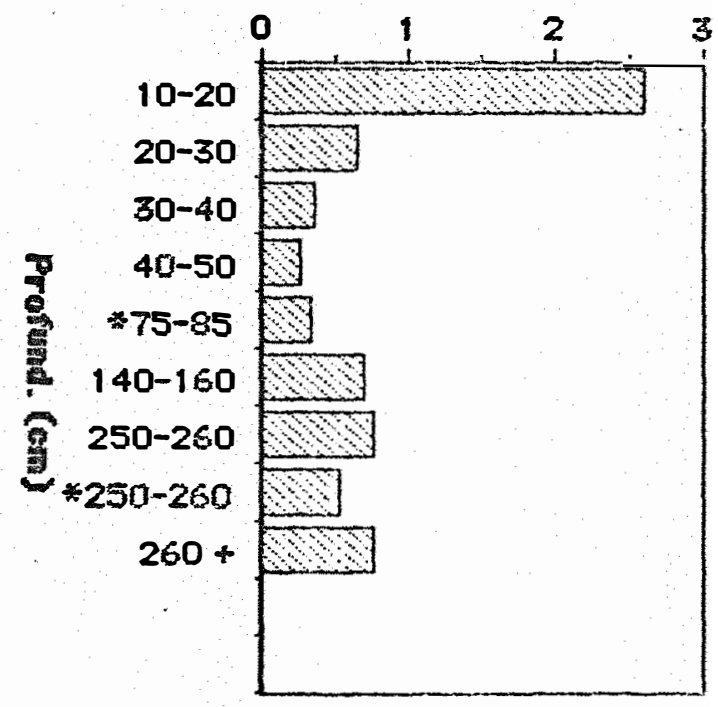

Figura 47 - Distribuicáo em profundidade dos teores de magnesio na solucăo extraida das amostras de solo e arena dos perfis analisados. 
As médias por perfil, dos teores

de manesio säo apresentadas a seguir:

- perfil NA1 =2, $6 \mathrm{mg} / \mathrm{l}$

- perfil NAs $4,48 \mathrm{mg} / \mathrm{I}$

- pertil NA3 - 2, 29 $\mathrm{mg} / \mathrm{l}$

- perfil NB1 u, $0,77 \mathrm{mg} / \mathrm{l}$

Essas médias determinadas estäo bem abaixo da média apresentada por Rosolem (1988) que está em torno de 2 a 5 milimoles $(24 \mathrm{mg} / \mathrm{l}\rangle$, afirmando ainda que, geralmente ocorre en dobro da concentracäo de potassio. Entretanto na Tabela 1.2 observa-we que tal afirmativa näo écorreta, porque o potássio ocorre na Solucäo desses solos com teores sempre ben superiores aos do manesio.

Por outro lado, ao se comparar seus teores com os teores do calcio, percebewse que os teores médios do magnésio säo todos inferiores aos do cálcio, isto porque, segundo Rosol.ter (1983), a energia de retencío do magnésio pelo complexo de troca é menor que o do cálcio, tendo como consequencia, maior disponibilidade de manésio às perdas e também maior potencial de I ixiviaza, em torno $2-30 \mathrm{~kg} / \mathrm{ha}$ ano.

Para melhor entendimento da dinâmica dos cations basicos nas duas toposseanencias estudadas, será apresentada de maneira resumida as médias por perfil dos teores de cátions básicos analisados conforme segre: 
10.) Perfil NA1: $\mathrm{K}(32,91 \mathrm{mg} / 1)>\mathrm{Na}(16,71 \mathrm{mg} / 1)>$ $\mathrm{Ca}(12,04 \mathrm{mg} / \mathrm{l})>\mathrm{Mg}(2,60 \mathrm{mg} / \mathrm{l})$;

20.) Perfil NA2: $\mathrm{Ca}(18,06 \mathrm{mg} / \mathrm{l})>\mathrm{K}(\mathrm{i} 1,21 \mathrm{mg} / \mathrm{l})$, $\operatorname{Na}(9,25 \mathrm{mg} / \mathrm{l})>M g(4,48 \mathrm{mg} / 1)$;

30.) Perfil NA3: Ca(14,98 $\mathrm{mg} / \mathrm{l})>\mathrm{K}(7,68 \mathrm{mg} / \mathrm{l})$, $M g(2,29 \mathrm{mg} / 1>\operatorname{Na}(0,73 \mathrm{mg} / 1)$;

40, Perfil NBi: $K(19,86 \mathrm{mg} / \mathrm{l})>\mathrm{Na}(6,6 \mathrm{Amg} / 1)$ > $\mathrm{Ca}(5,04 \mathrm{mg} / \mathrm{l})>\mathrm{Mg}(0,77 \mathrm{mg} / 1)$;

\section{Manganês}

A figurat 48 apresenta a distribuisäo em profundidade dos teores do ion manganês na solucäo do solo extraida das amostras de solo e arena dos pertis estudados. Os perfis NA1, NA3 e NBA mostram que os seus maiores teores se concentram na porcáo superficial dos seus solos, seguindo pelo declinio em profundidade, coincidindo com as camadas em que há predominância da arena granitica avermelhada.

No pertil NAz verifica-ise que o teor de manganes é menor no horizonte superficial (1,83 mg/1) na camada de $1-5 \mathrm{~cm}$ e cresce subitamente para teores de $3,38 \mathrm{mg} / \mathrm{l}$ na profundidade de 5 -10 cm. A partir dai, decresce gradat ivamente para valores de até $0,21 \mathrm{mg} / \mathrm{l}$ na profundidade de $75-85 \mathrm{~cm}$, seguindo por um leve acréscimo até a profundidade observada.

No geral verificamse que os 
Mn (mg/1)-Perfil Pal

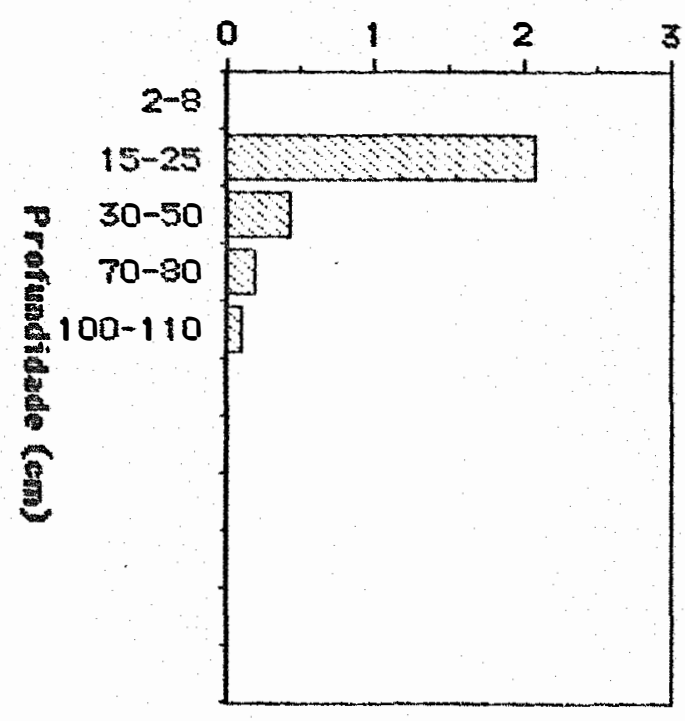

Mag (on-min

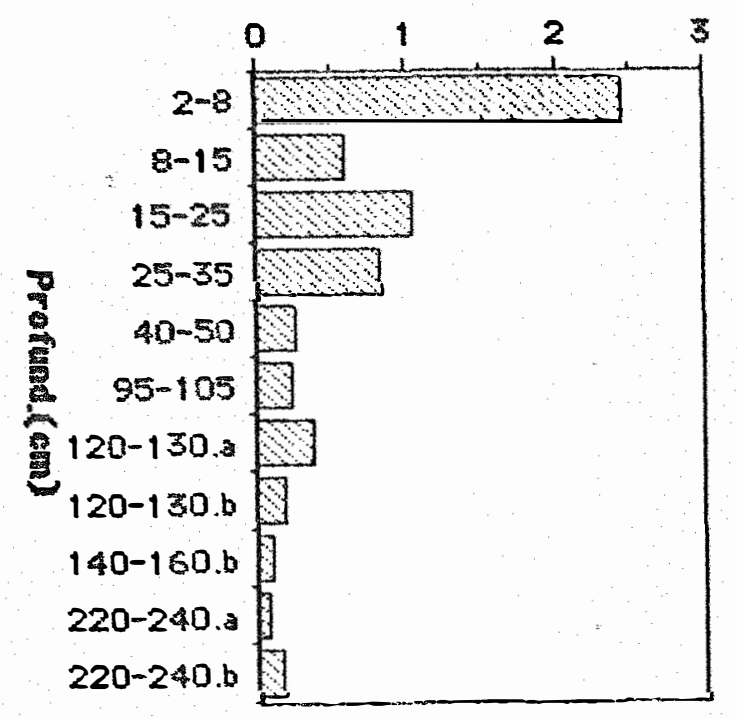

Mn (mg/1)-PERIIIA2

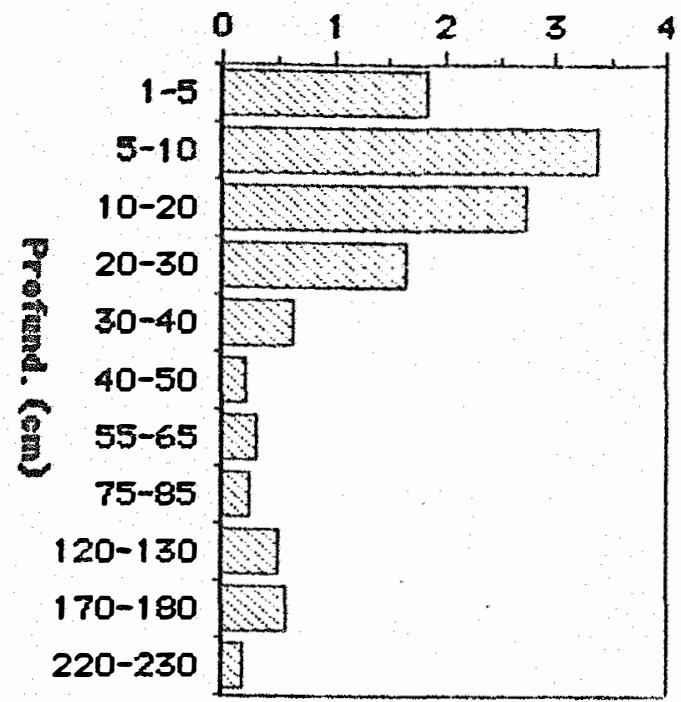

Figura 48 Distribuicio en profundidade dos teores de manganes na soluăo extraida das amostras de 5010 arena dos perfis anal isados. 
maiores teores de manganes da solucáo do solo se concentram na porgäo superior dos perfis analisados e o Elemento, segundo Mal..uvolita (1976), provavelmente se encontra no estado de valência tê pelo fato de ser este, o predominante na solucäo, embora o estado de valência +3 possa também existir em solugä́ desde que devidamente complexado.

As medias por perfil, dos teores de manganés säo apresentadas a seguir:

$$
\begin{aligned}
& \text { - Perfil NAI }=0,69 \mathrm{mg} / 1 \\
& - \text { perfil NAE }=1,12 \mathrm{mg} / \mathrm{l} \\
& \text { - pertil NAB }=0,58 \mathrm{mg} / 1 \\
& \text { - perfil NBI }=0,28 \mathrm{mg} / 1
\end{aligned}
$$

Ao compararmos as médias dos teores de manganés na solugäo do solo dos perfis diue compöem a topossequência $N A$, com os selus respectivos valores de pH, observa-se que ha uma perfeita correspondência entre valores: teor de Mn $x$ pH da solucáo. Assim sendo, o perfil NAz o qual apresenta o teor mais elevado de 1, feng/l apresentold o valor mais elevado do pH igual a 7,32, seguindo pelo perfil NA1 e depois, pelo Perfil NA3. Acreditamse portanto que o pH influencia diretamente a solubilidade desse elemento. malmavol.ta (1976) observa que o potencial redox e o pH tem influencia marcante na forma e distribuiço do manganês no perfil. o mesmo autor observa também que as reacobs quimicas responsaveis pela interconversäo da forma di, tri e tetra do manganês säo influenciadas por bactérias e fungos. 


\section{Aluminio}

A distributafio en profundidade dos teores do ion aluminio na solucäo do solo extraida das amostras de solo e arena dos perfis estudados é apresentada na Figura 49. Deve-se salientar que o ion aluminio apresentou valores discrepantes, a exemplo do teor de ate 25, 5e mo/l determinada na canada de 8-15 cm de profundidade no perfil NA3. A mesma tendência observada neste perfil quanto à sua distribuicăo em profundidade ocorre com relacáo ao ion fre na solucäo do solo deste mesmo perfil, mas em concentragies bem inferiores a do aluminio.

Com relacio aos demais perfisi, näo se observa nenhuma similaridade quanto à tendência de distribuicáo em profundidade dos seus teores. Assim sendo, o perfil NA2, apresenta um teor mais elevado na sua superficie, declinando até a profundidade de $30-40 \mathrm{~cm}$, a partir dai, un acrescimo seguido de decrescimo e novamente acréscimo na camada de $220-230 \mathrm{~cm} d e$ profundidade, onde há predominâcica da arena granitica amarelada.

As médias por perfil, dos teores de aluminio, säo apresentadas a seguir:

$$
\begin{aligned}
& \text { - perfil NAS }=0,23 \mathrm{mg} / \mathrm{l} \\
& \text { - perfil NA2 }=0,49 \mathrm{mg} / \mathrm{l} \\
& \text { - perfil NA3 }=4,42 \mathrm{mg} / \mathrm{l} \\
& \text { - perfil NBS }=0,34 \mathrm{mg} / \mathrm{l}
\end{aligned}
$$


Al (ong/1)-Perfil WA1

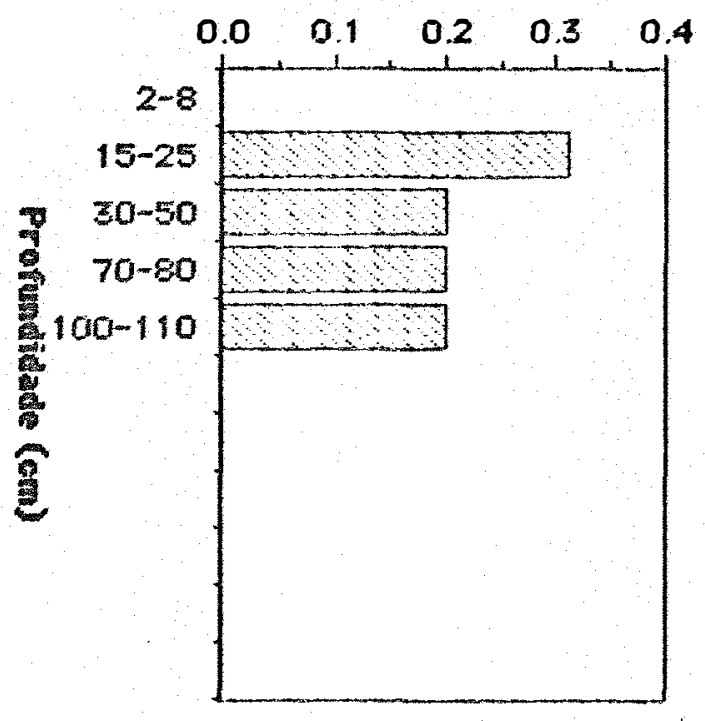

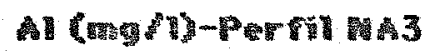

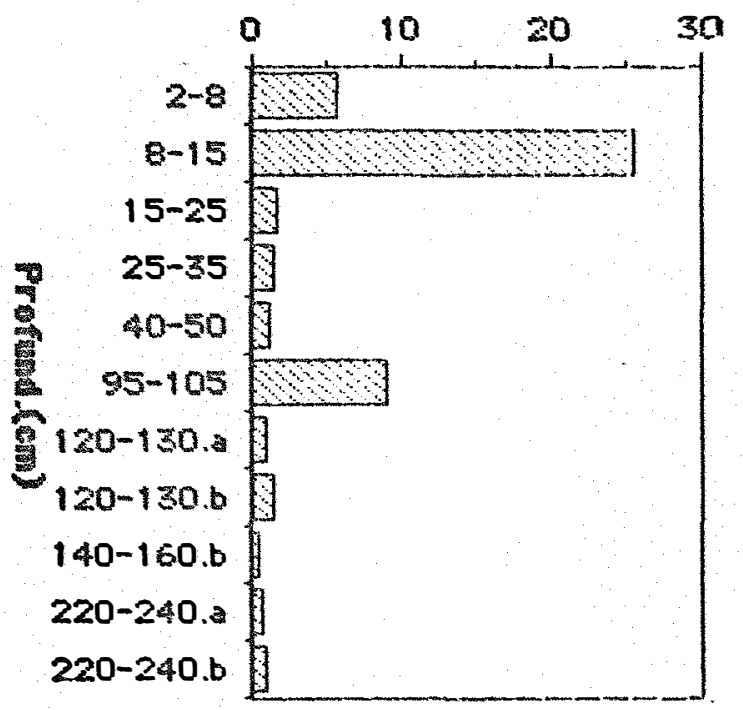

Al (mg/I)-Perfin RA2

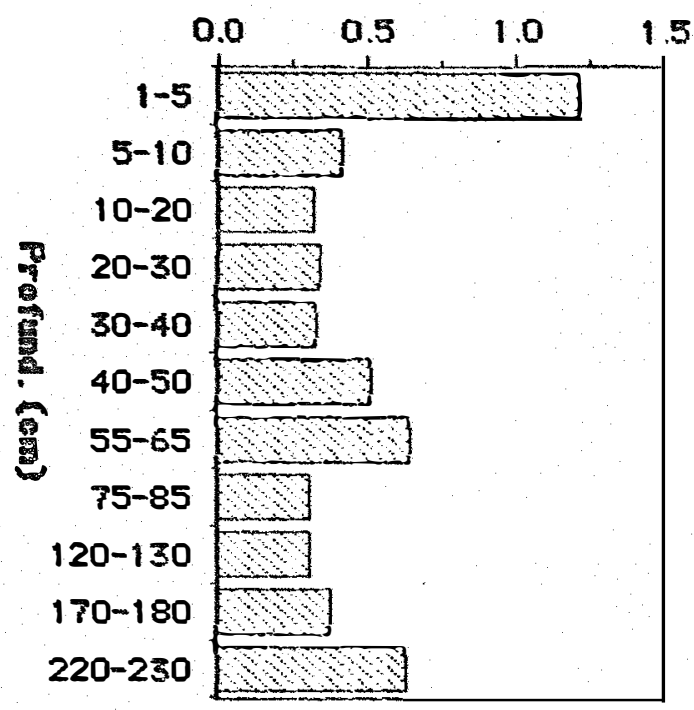

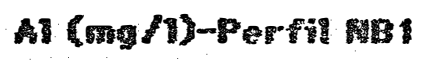

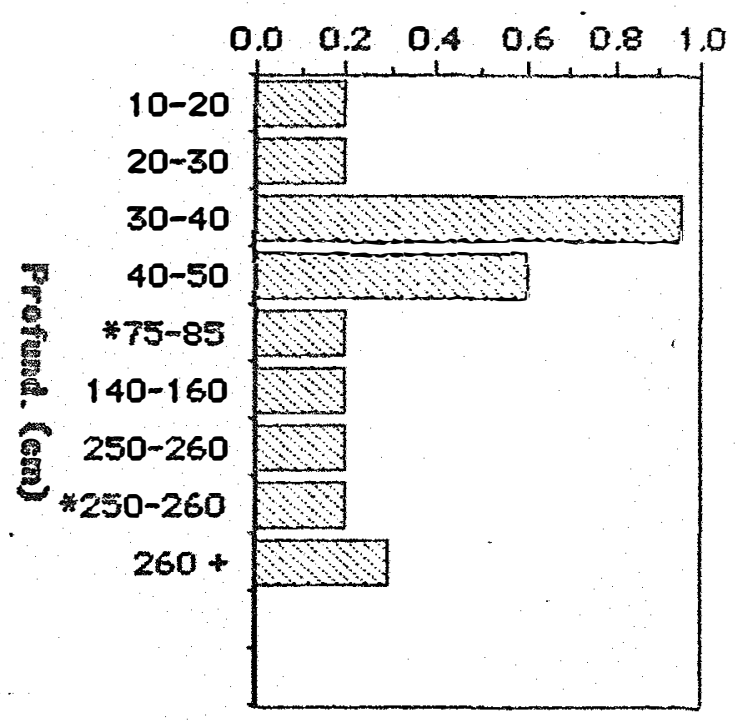

Figura Ag - Distribuiga em profundidade dos teores de aluminio na solutáo extraida das amostras de solo e arena dos perfis analisados. 
Com excecä́ do perfil NA3, os teores de aluminiona solucaro do solo dos demais perfis Säo baikos, en decorrência do pH na neutrazidade e ligeiramente alcalino. Malavolta (1976) observa que o alumínio permanece em solucáo em condicbes ácidas (pH 4,0$)$ ou basicas (pH 9,0) enquanto que, perto da neutral idade, o aluminio pode precipitar na forma de hidroxido. Assim sendo, a quantidade de alumínio na solucáo do solo está relacionada com o PH da mesma.

\section{Ferro}

Com relacăo distributä́o em profundidade do teor do ion ferro na solucáo do solo extraida das amostras de solo e arena dos perfis analisados, verifica-se atraves da figura bo que o perfil NA2 apresenta uma tendencia en concentrar maiores teores na sua portáno superficial, seguido pelo declínio gradativo até a profundidade de $120-130 \mathrm{~cm}$, a partir dai, um acréscimo na camada de $220-230$ om de profundidade, onde há predomínio da arena granitica amarelada. Conforme se observa na mesma figura, näo foi possivel realizar as análises nos perfis NAS e NA3, pois os mesmos nä́o apresentam todos os dados.

A tendência em concentrar maiores teores de ferro na porgáo superficial dos perfis anal isados se deve à grande quantidade de complexos de

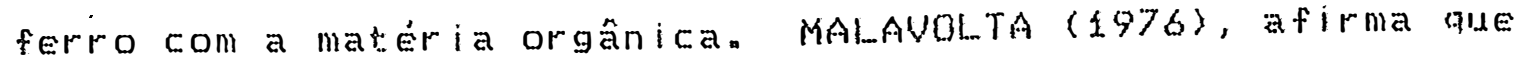
$+3$

o Fe inorgânico total em solucăo varia com opHe atinge 
Fe (mg/D)-Perfil wA

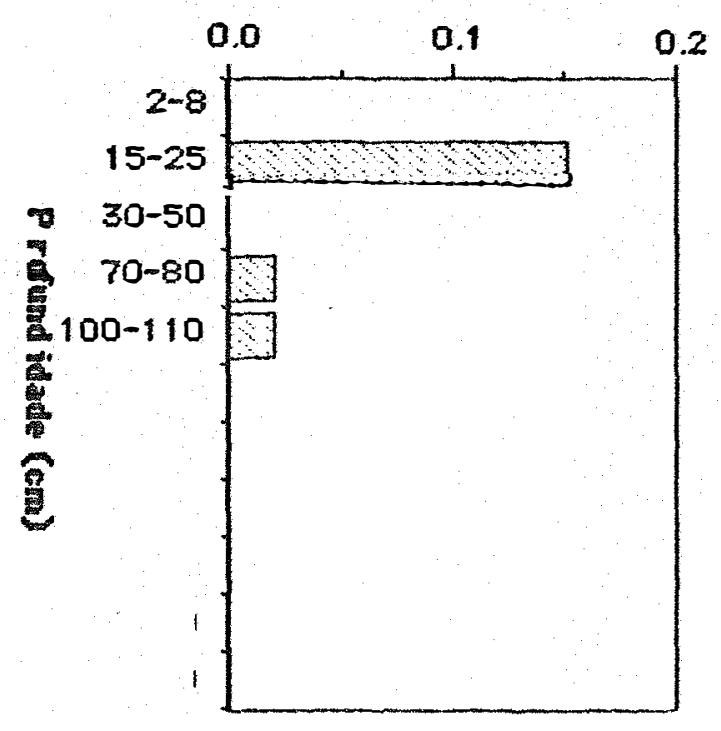

Fe (mol D)-Pertin ma

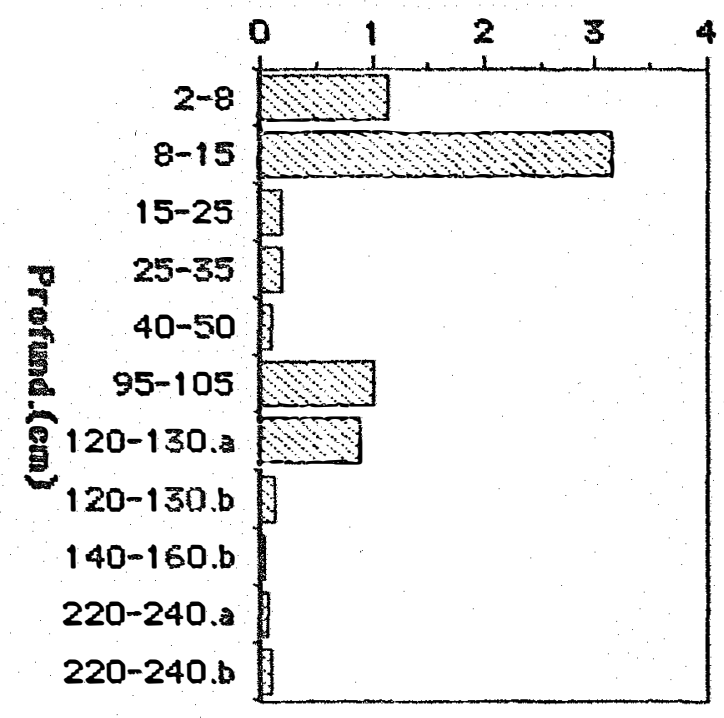

Fe (mold)-Pertil VA2

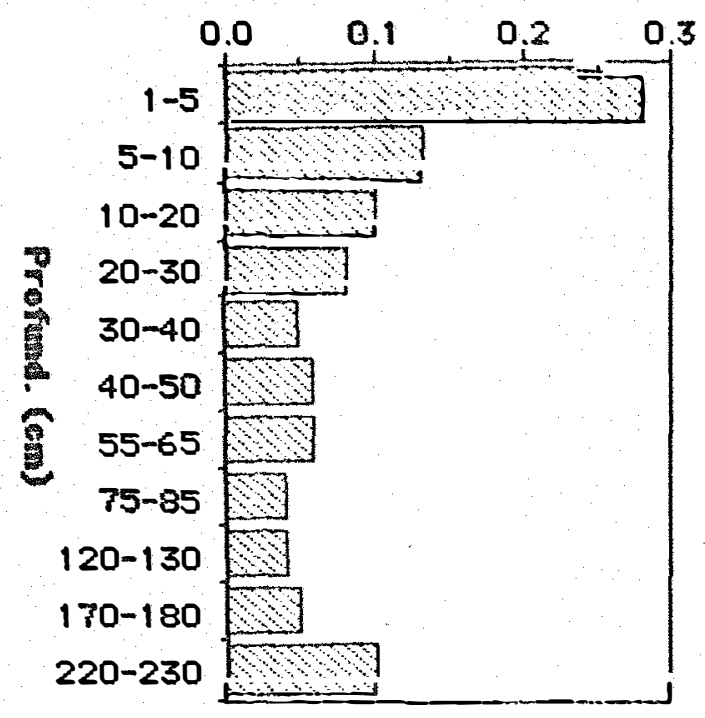

Fe (mgli)-Perfil

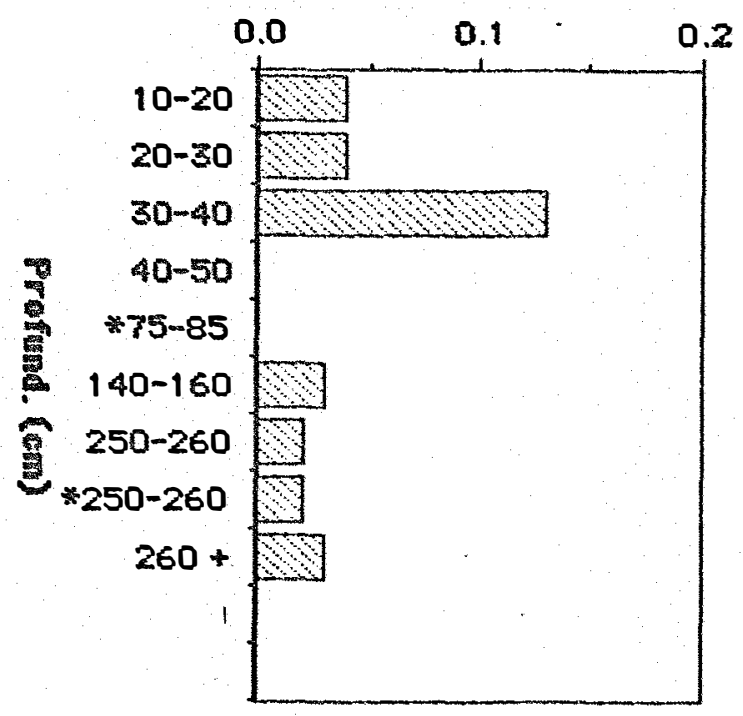

Figura so bistribuifán em profundidade dos teores de ferro na solucáo extraída das anostras de solo earena dos perfis anadisados. 
um minimo na faixa de $6,5-8,0$, sendo que as espécies hidroliticas constituem uma porgáo maior dos ions Fe $\mathrm{Fm}$ solucăo. o mesmo autor, afirma ainda que a quimica do ferro na solucäo no solo é complicada pela grande quantidade de ferro coloidal presente e pela relacáo do ferro com a matéria orgânia.

As médias por perfis, dos teores de ferro na solucáo do solo, säo apresentadas a seguir:

$$
\begin{aligned}
& \text { - perfil NAI }=0,06 \mathrm{mg} / \mathrm{l} \\
& \text {-perfil NA3 }=0,09 \mathrm{mg} / \mathrm{l} \\
& \text {-perfil NA3 }=0,60 \mathrm{mg} / \mathrm{l} \\
& \text { - perfil NBI }=0,04 \mathrm{mg} / \mathrm{l}
\end{aligned}
$$

Analisando essas médias, percebe-we que seus valores săo baikos em decorrencia do percentual mito pequeno da biotita no material de partida, pois é o mineral que libera o ferro no processo da sua alteracóo.

Cutro detalhe importante a ser observado é que as suas médias apresentadas por perfil, refletem o incremento do seu teor no sentido descendente da encosta em decorrência da acáo do fluxo lateral da água, preconizado por MONIZ et alii (19832).

\section{Zinco}

A figura 51 apresenta a distribuicáco em profundidade dos teores do ion zinco na solucäo do solo extraida das amostras de solo e arena dos perfis estudados. Percebe-se qua a sua concentrafío é 

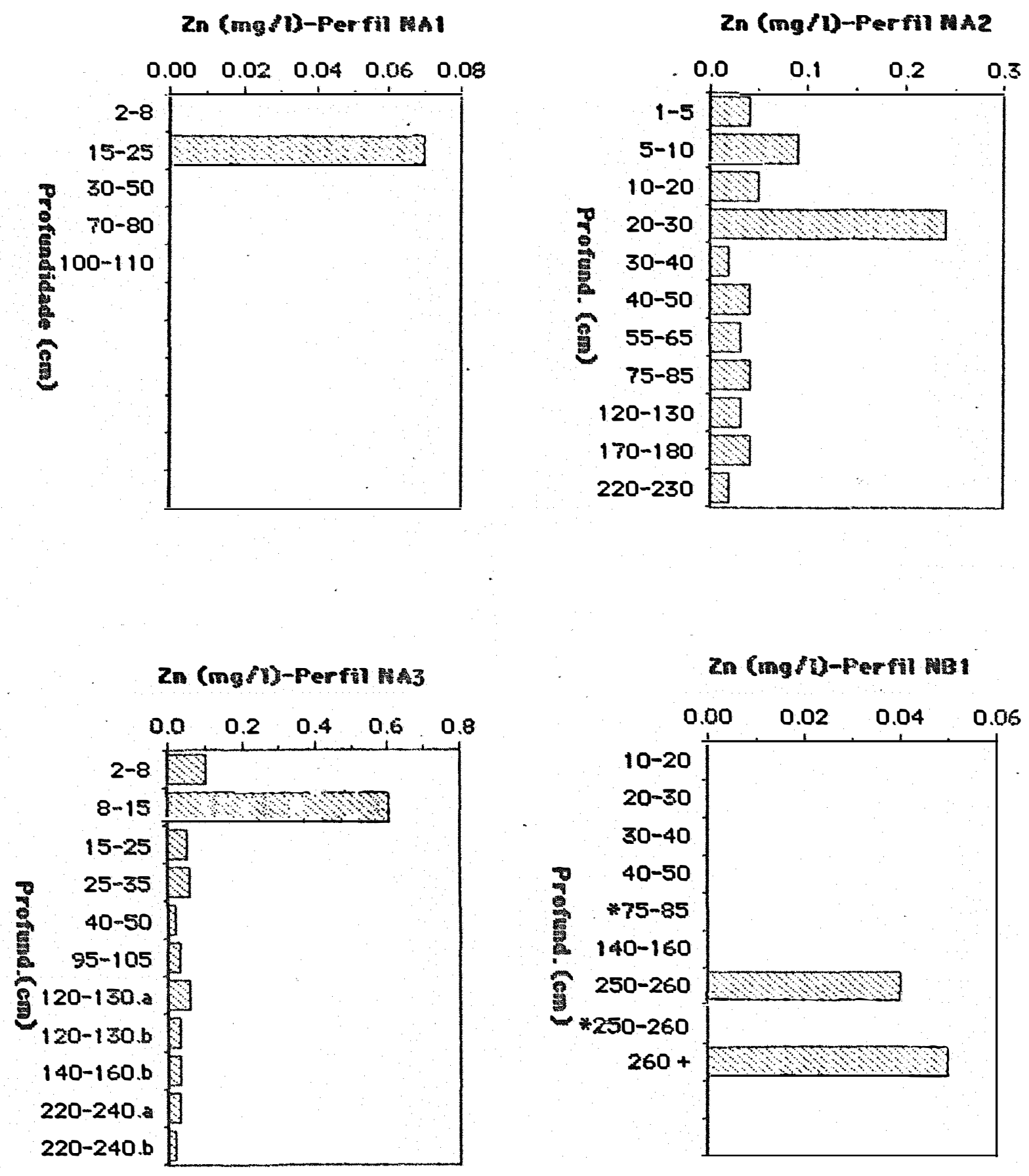

Figura 51 - Distribuicáo em profundidade dos teores de zineo na solucio extraida das amostras de solo e arena dos perfis analisados. 
baixa, pois apresenta teores de 0,02 e $\theta, 6 \theta \mathrm{m} / \mathrm{l}$ como valores minimo e máximo respectivamente. Nos perfis NA2 e NA3, percebe-se que o seu teor é baixo no horizonte superficial e com tendência a acréscimo máximo na profundidade de $20-30 \mathrm{~cm}$, declinando abruptamente para niveis mínimos, conforme já foi mencionado. A falta de dados para os perfis NAt e NBi náo permite analisar a tendência quanto a sua distribuiçóno em protundidade nos mesmos.

Os teores médios por perfil na solusáo do solo dos pertis analisados sä́o apresentados a seguir:

$$
\begin{aligned}
& \text { - perfil NAI }=0,07 \mathrm{mg} / \mathrm{l} \\
& \text { - perfil NA2 }=0,06 \mathrm{mg} / \mathrm{l} \\
& \text { - perfil NA3 }=0,09 \mathrm{mg} / 1 \\
& \text { - perfil NBI }=0,04 \mathrm{mg} / \mathrm{l}
\end{aligned}
$$

Anal isando os teores médios de zinco na solufáo do solo e os valores médios do pH dos pertis analisados, percebe-se que os teores médios do ion zinco decrescem com o aumento dos valores médios do pH. Isto se explica pelo fato do ion anco tornar-se insolivel em pH elevados. MAl. AVOLTA $(1976)$, afirma que no pH 5,0 a $+2$

concentracío de žn en solusäo é aproximadamente $1 \ddot{0}(6,5$ ppm), já no pH $8, \theta$ é $1 \bar{\theta}^{10} \mathrm{n}(0,007$ partes por bilhäod, isto $+2$ por que a solubilidade do zn é altamente dependente do pH e diminui 100 veres para cada incremento de 1 unidade de pH. A deficiência de zn induzida em solos ácidos por 
calagem excessiva pode ser explicada facilmente por essa relacão de dependência com o pH. En valores baixos de pH alguns Zn pode estar presente no complexo de troca do solo; em valores altos de pH porém, o nivel de zn em solugäo é täo baixo que muito pouco $Z_{n}^{+2}$ ficará preso ao complexo de troca. SOUZA (1988) também afirma que para valores de pH acima de 7,5 , tem-se as formas insoluveis como o $\mathrm{Zn}(\mathrm{OH}) 2, \mathrm{ZnS}(\mathrm{OH}) \mathrm{G}(\mathrm{CO} 3)_{2}$.

Dutro fator também relacionado com os baikos teores de zinco na solucäo do solo dos perfis analisados, é devido a mineralogia desses solos ser constituida basicamente por argilas caoliniticas, pois conforme afirma SOUZA (1988) a adsorfäo do zinco promovita pelas argilas obedecem a seguinte ordem decirescentes:

caolinita $>$ ilita $>$ montmorilonita $>$ vermiculita.

Fisforo

A distribuicăo en protundidade dos teores de fósforo na soluca do solo extraida das amostras de solo e arena dos perfis NA1, NA2 e NA3, está representada na figura 52 . Observa we que as concentracís do ion fósforo na solucäo do solo extraida das amostras dos perfis NA2 e NA3 säo bastante semelhantes. 0 teor maximo de $0.57 \mathrm{mg} / 1$ toi obtido na amostra superficial do perfil NAE, seguindo pelo decréscimo logo na camada subjacente para o teor de $0,18 \mathrm{mg} / ?$, continuando alternadamente com acréscimo e decréscimo en profundidade. 

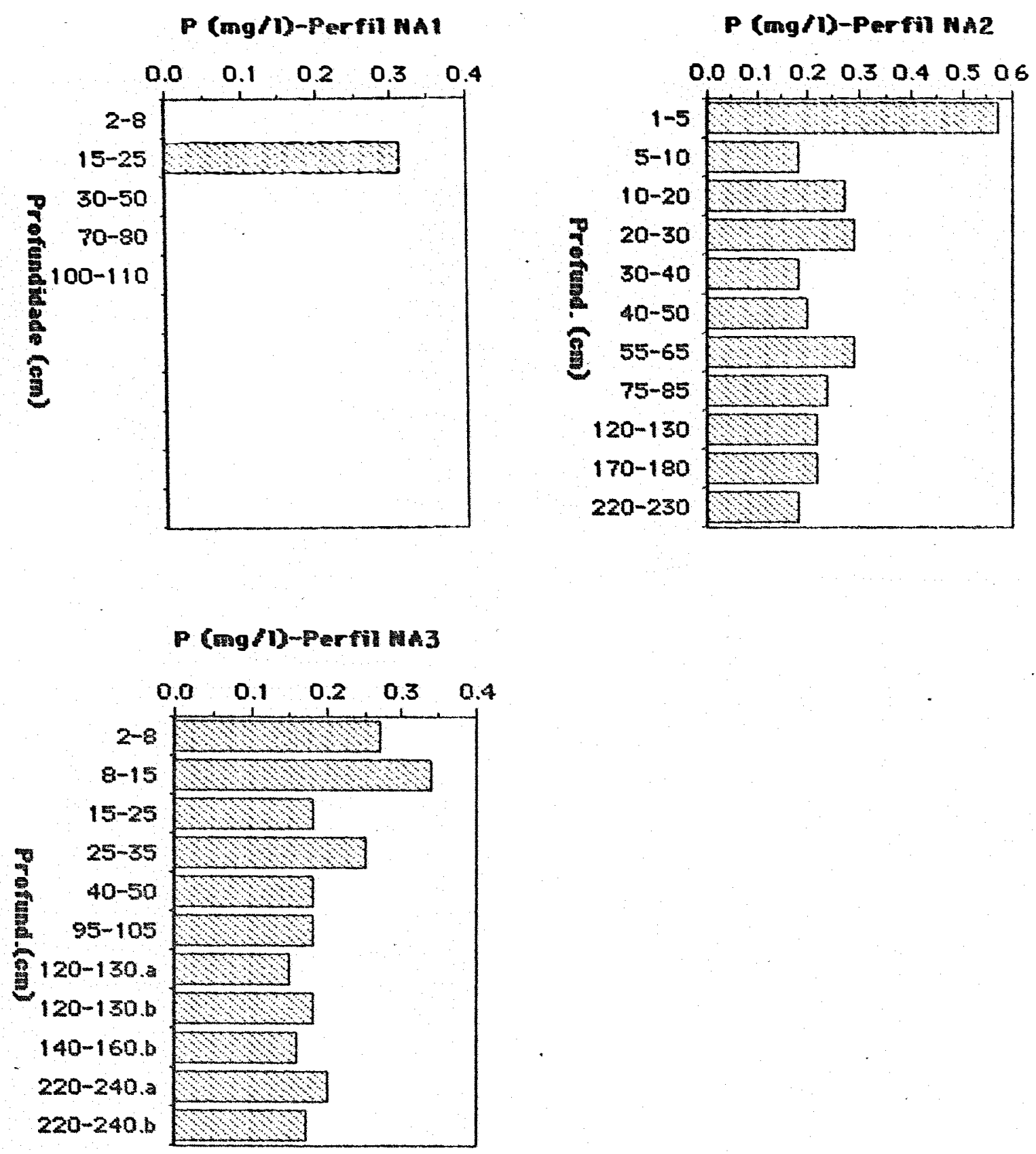

Figura gen Distribuiga em profundidade dos teores de fustoro na soluáco extraida das amostras de 5010 e arena dos perfis anal isados. 
A mesma tendência é observada no perfil NA3.

o teor de fósforo un pouco nais elevado na porcäo superficial do solo, é consequência do maior teor de matéria orgânica depositada constantenente na superfície desses solos, o qual, ao se decompor pelos microorganismos, irá fornecer ao complexo de troca, o fósforo de origen orgânica.

As médias por perfil, dos teores de fósforo na solucáo do solo dos perfis analisados säo apresentados a seguir:

$$
\begin{aligned}
& \text { - perfil NA1 }=0,31 \mathrm{mg} / \mathrm{l} \\
& \text { - perfil NA2 }=0,26 \mathrm{mg} / \mathrm{l} \\
& \text { - Perfil NA3 }=0,21 \mathrm{mg} / \mathrm{l}
\end{aligned}
$$

Comparativamente essas medias dos teores de fósforo na solucäo do solo estäo acina da média apresentada por RAIJ (1988) que é de $0,1.49 / \operatorname{cm} 3(0,1$ mg/1). Esse mesmo autor, a inda afirma que apesar clos teores de fósforo serem baixos na solucáo do solo, ocorre una constante reposicäo do fúsforo na solugäo do solo, através da dissolucäo do fosfato lábil, que está en equilíbio com o fosfato en solucáo.

$$
\text { pH }
$$

A figura $\mathrm{g} 3$ apresenta a distribuicáo em profundidade dos valores de pH da solucáo do solo extraida de amostras de solo e arena dos perfis analisados. Nos perfis NA3 E NB1, observa-se que seus valores tenden a un meio neutro nas amostras superficiais 

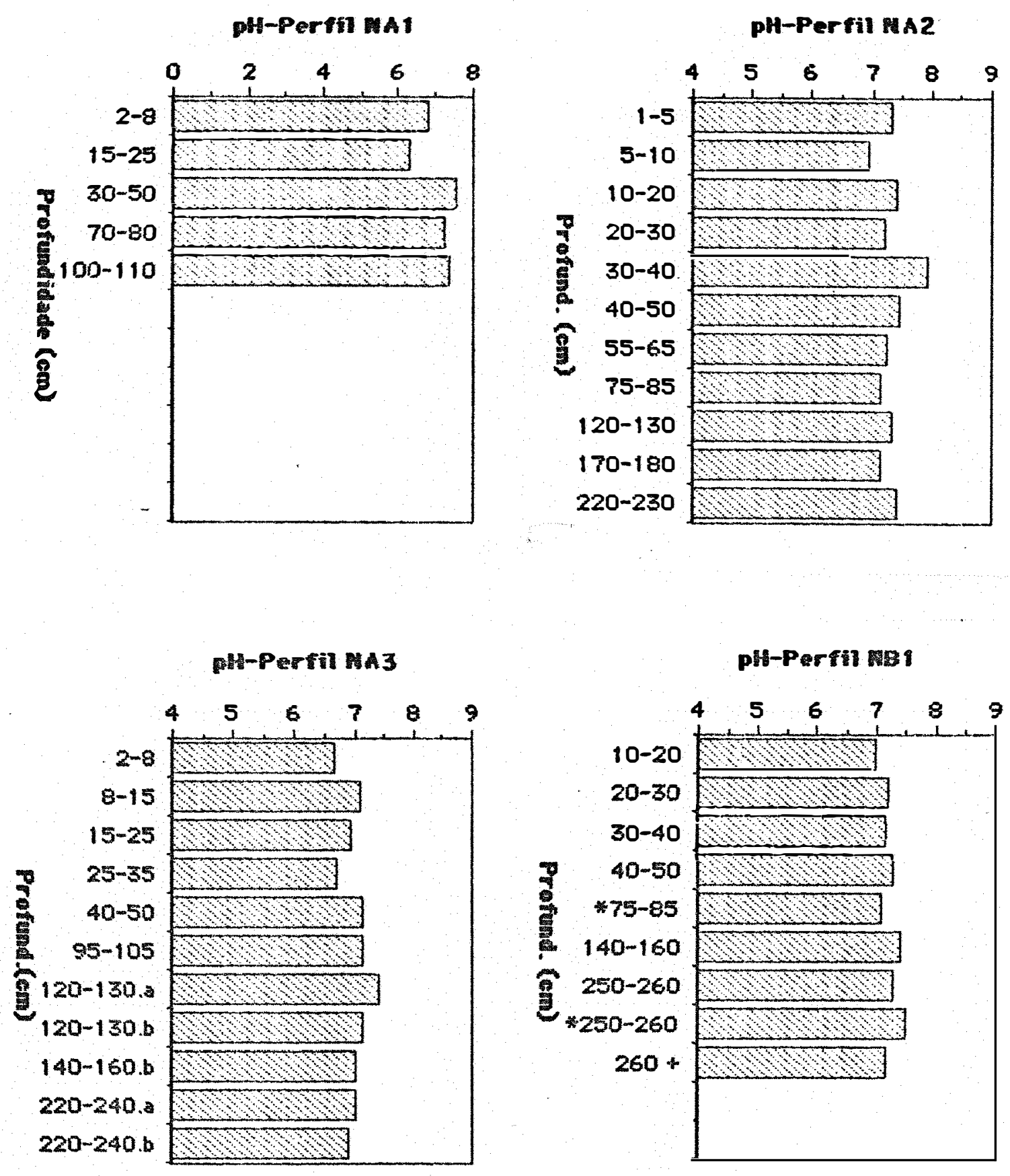

Figura 53 - Distribuigáo em profundidade dos valores de pH na solucäo extraida das amostras desolo e arena dos perfis anadisados. 
e, ligeiramente alcalino en profundidade a partir dos $20-30 \mathrm{~cm}$ de profundidade.

Já no perfil NAI; observa-se un ligeiro decréscimo até a profundidade de $15-25 \mathrm{~cm}$ e após, segue pelo incremento para valores do meio ligeiramente alcalino. A mesma tendência é observada no perfil NA2, diferindo apenas no pH da amostra superficial que é mais elevado, condicionando o meio ligeiramente alcalino.

Com excegáo do perfil NAz, observase que o pH da solugäo do solo tende a ser mais baiko nas camadas superiores dos perfis analisados, apesar da soma dos teores de cátions. básicos ser ben mais elevada nesta porcäo superficial. Tal fato deve estar relacionado ao maior teor de matéria organica, e ao maior teor de coz liberado pela respiracáo edáfica a qual envolve tanto a respiracăo radicular como tambén, a respiracáo da biomassa microbiana. 0 processo que envolve essa ligeira acidificacáo é explicado por Bul... (1.988) de maneira resumida:

a) o Co. se dissolve na solugä́ do solo e o ácido carbônico resultante se dissocia liberando o próton H+ na solugáo;

b) a dissociacäo do ion H+ de grupos carbonilicos e fenólicos da matéria orgânica, fornece pritons ao solo;

c) quando a lißiviagáo é muito intensa, a concentracáo da solucăo do solo se torna extremamente bai 
d) o Enxofre da matéria orgânica en solos normalmente arejados säo transfornados para ácidos, pela acáo dos microorganismos, através da seguinte reacáo:

$$
\begin{aligned}
& \text { S orgânico -......... }
\end{aligned}
$$

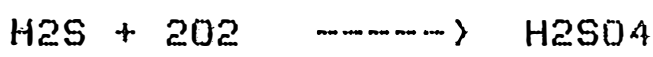

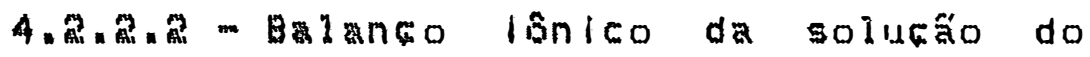
5010

Neste item será apresentado os resultados referentes ao balango ionico realizado para a solucăo extraida das amostras de solo, e arena dos perfis analisados. Apesar do balanco iónico inplicar na quantificacăo total de todos ânions e cations, pretende-se demonstrar aqui, a diferenca quantitativa entre os totais dos principais ânions e cations identificados e dosados nas amostras da solugáo extraida de amostra de solo e arena dos perfis NA1, NA2, NA3 E NB1.

Inicialmente as Tabelas de no. 13 a 16 apresentam os teores médios dos ions na solugấo do solo, calculados en $\mu$ mol/l. As Tabelas de no. 17 a 20 , apresentan os referidos dados transformados em $\mu$ eq/ permitindo assim, avaliar a quantidade e respectivo saldo dos ânions e cátions identificados e dosados na solucăo desses solos.

No pertil NAS percebe- se a ausencia de dados referentes ao horizonte Al1 ( $2-8 \mathrm{Cm}$ ) en 


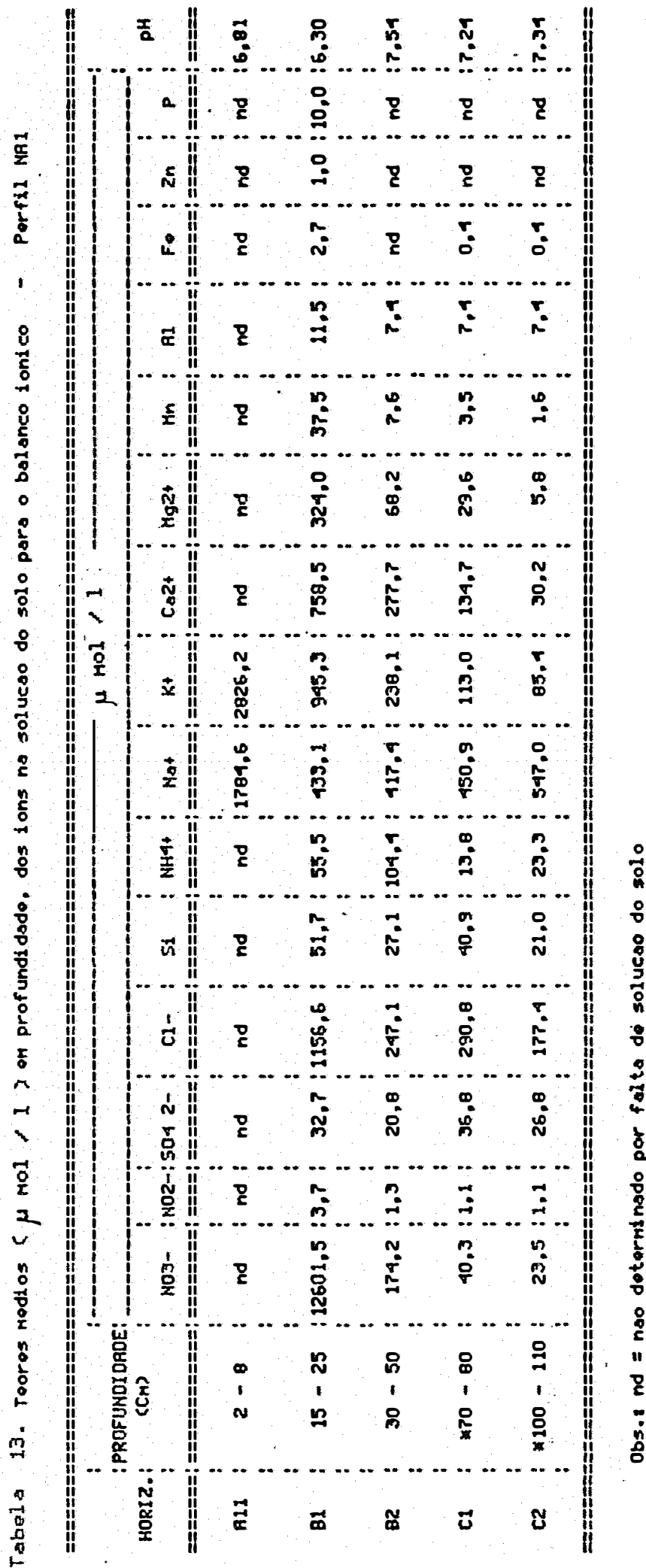




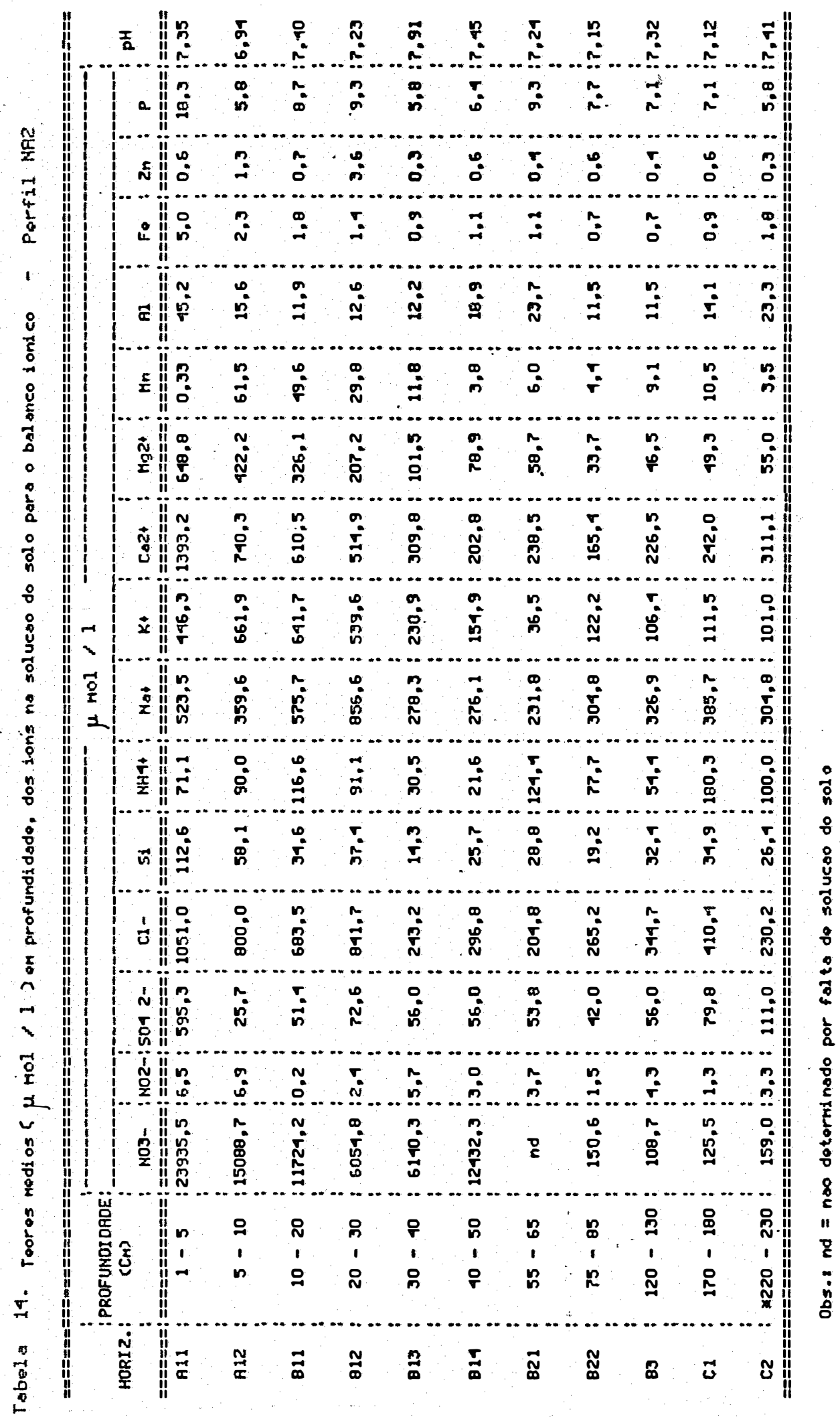




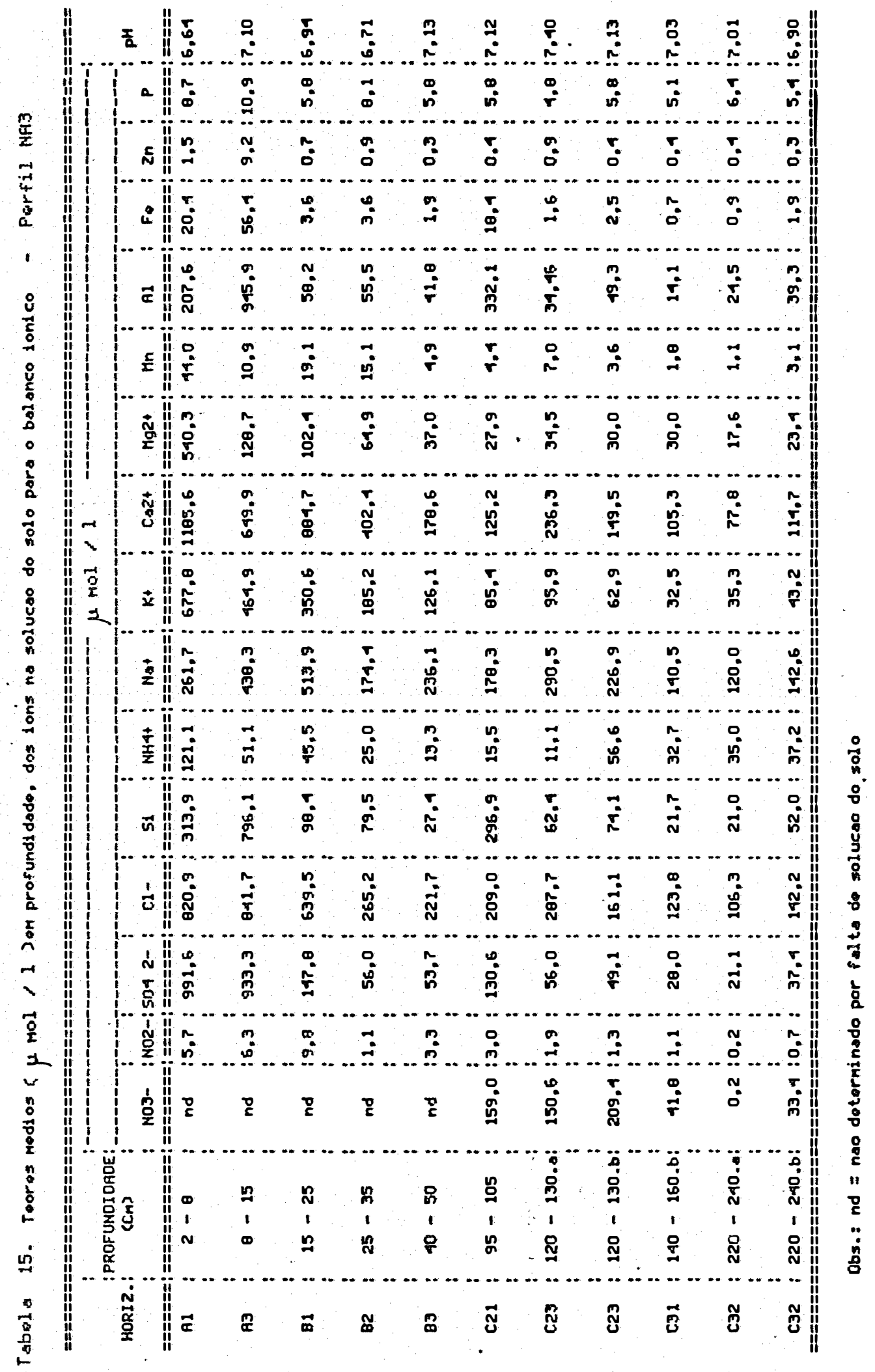




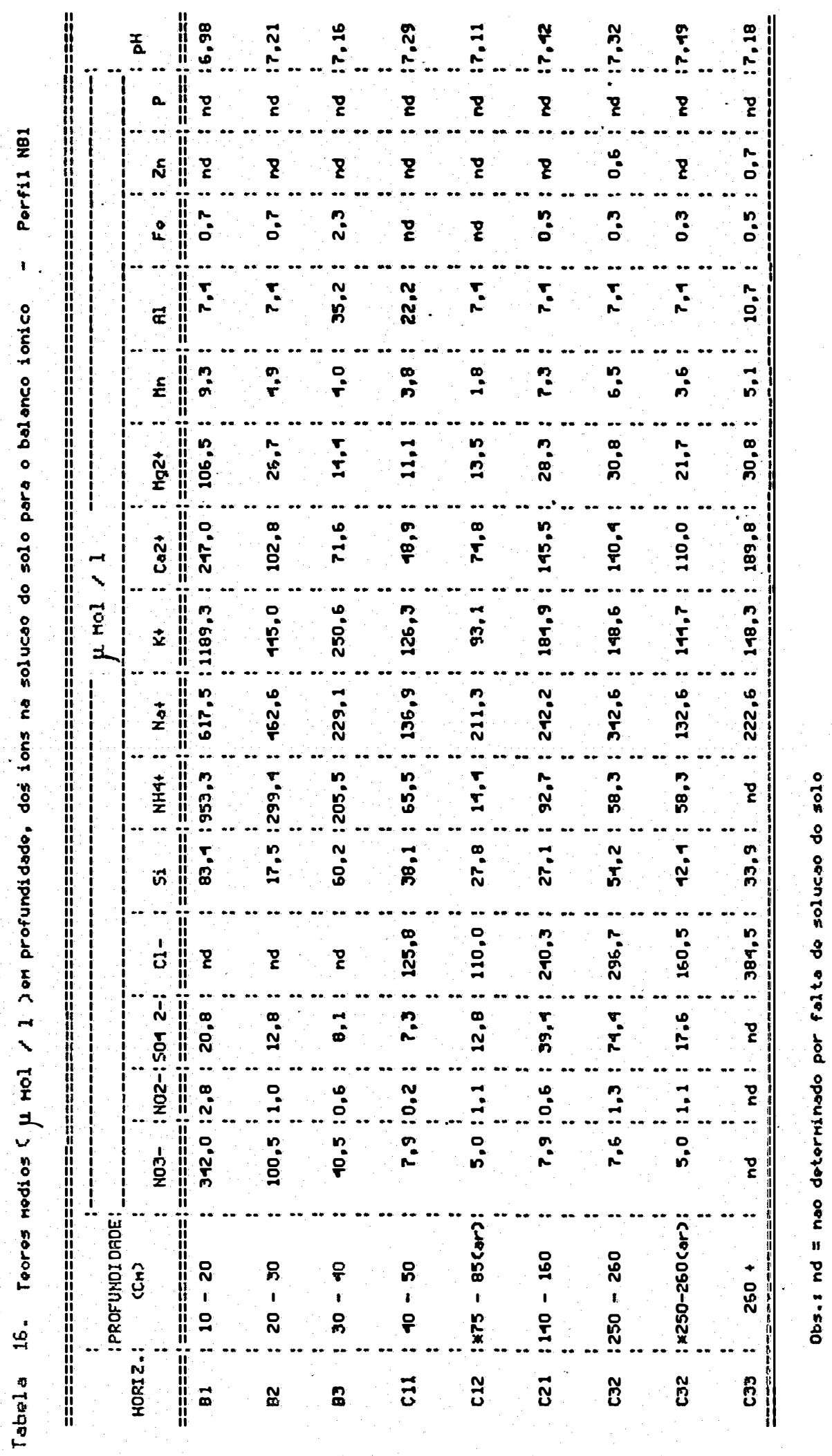




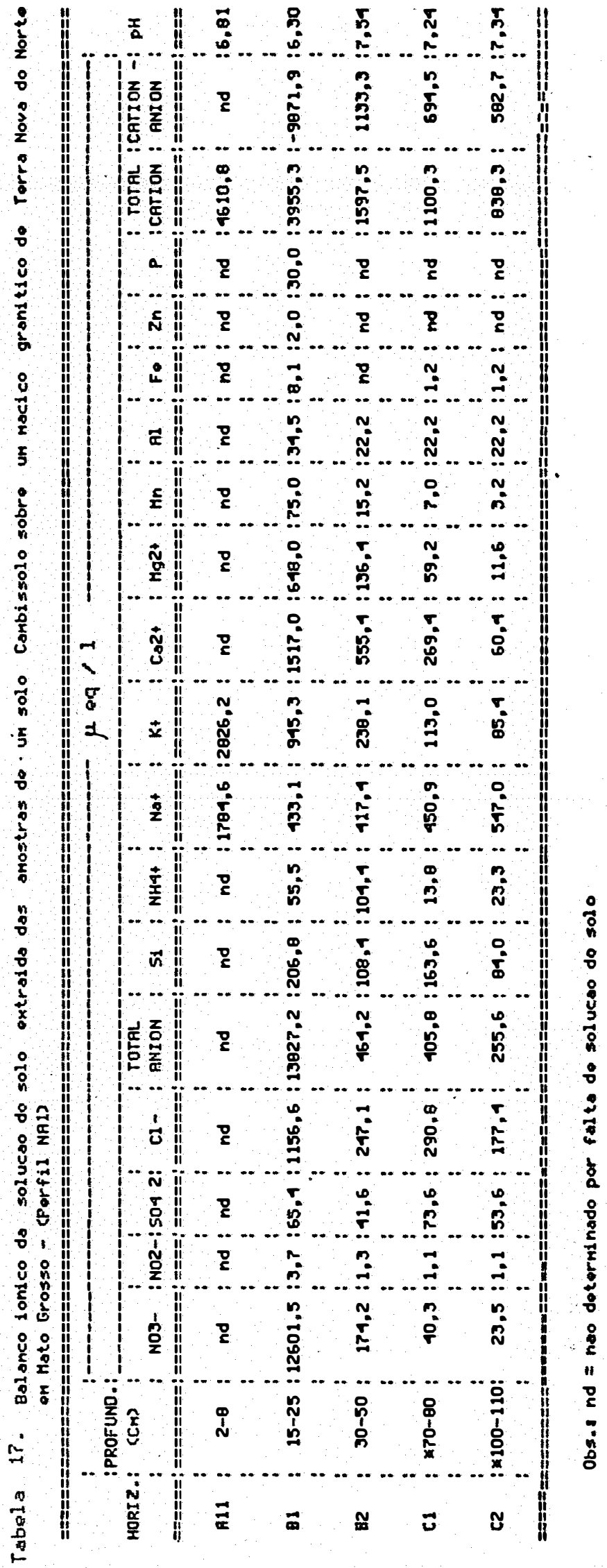




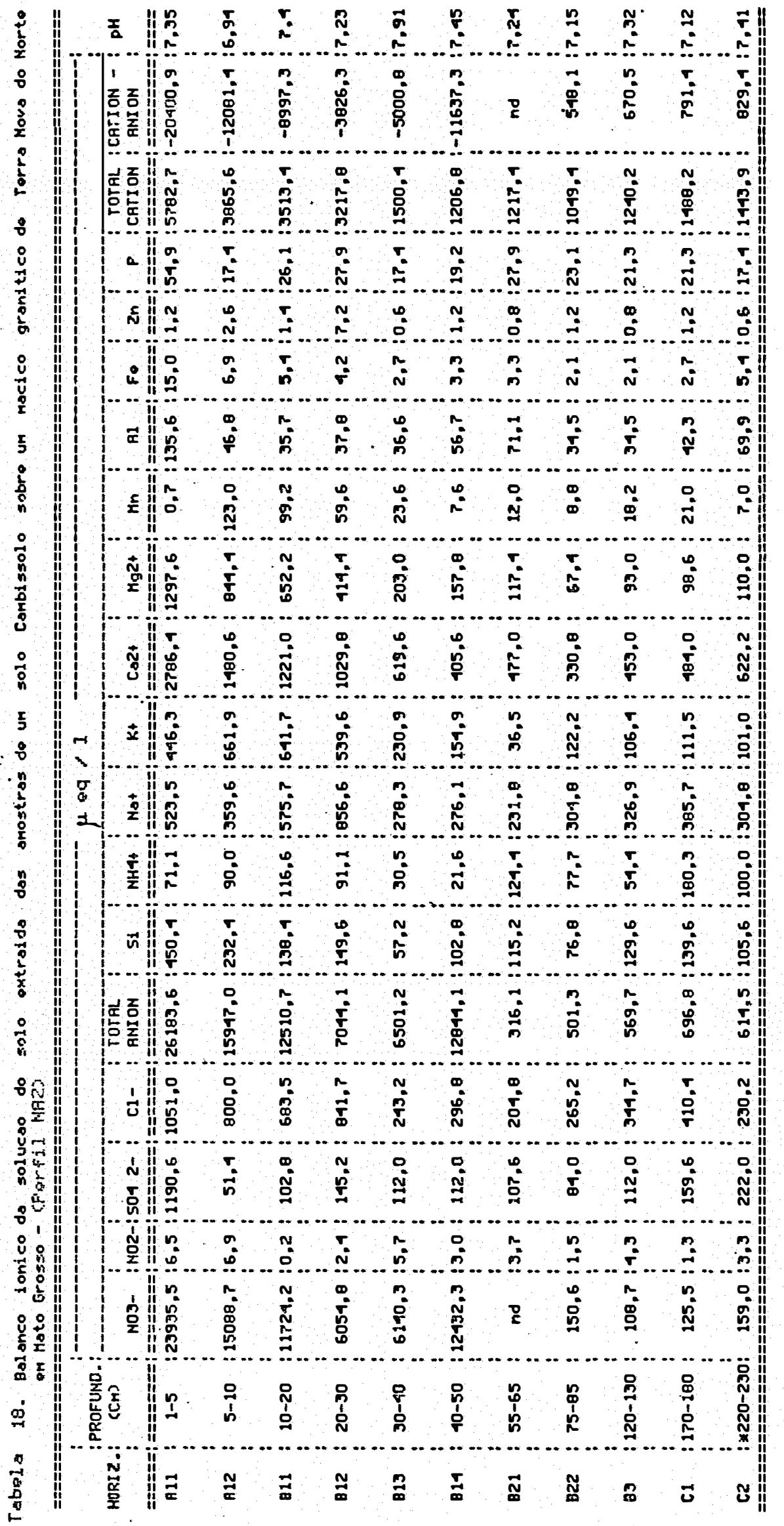




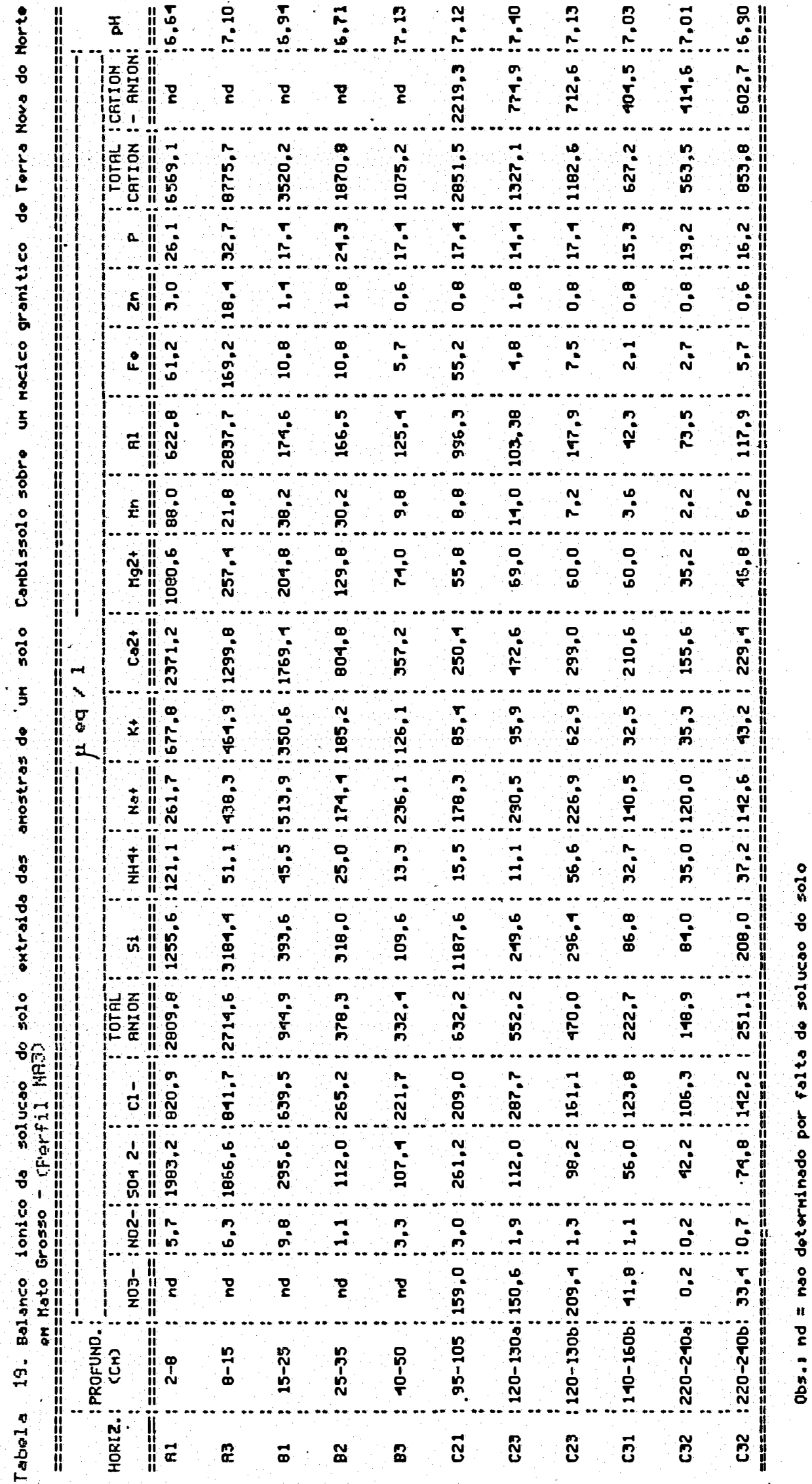




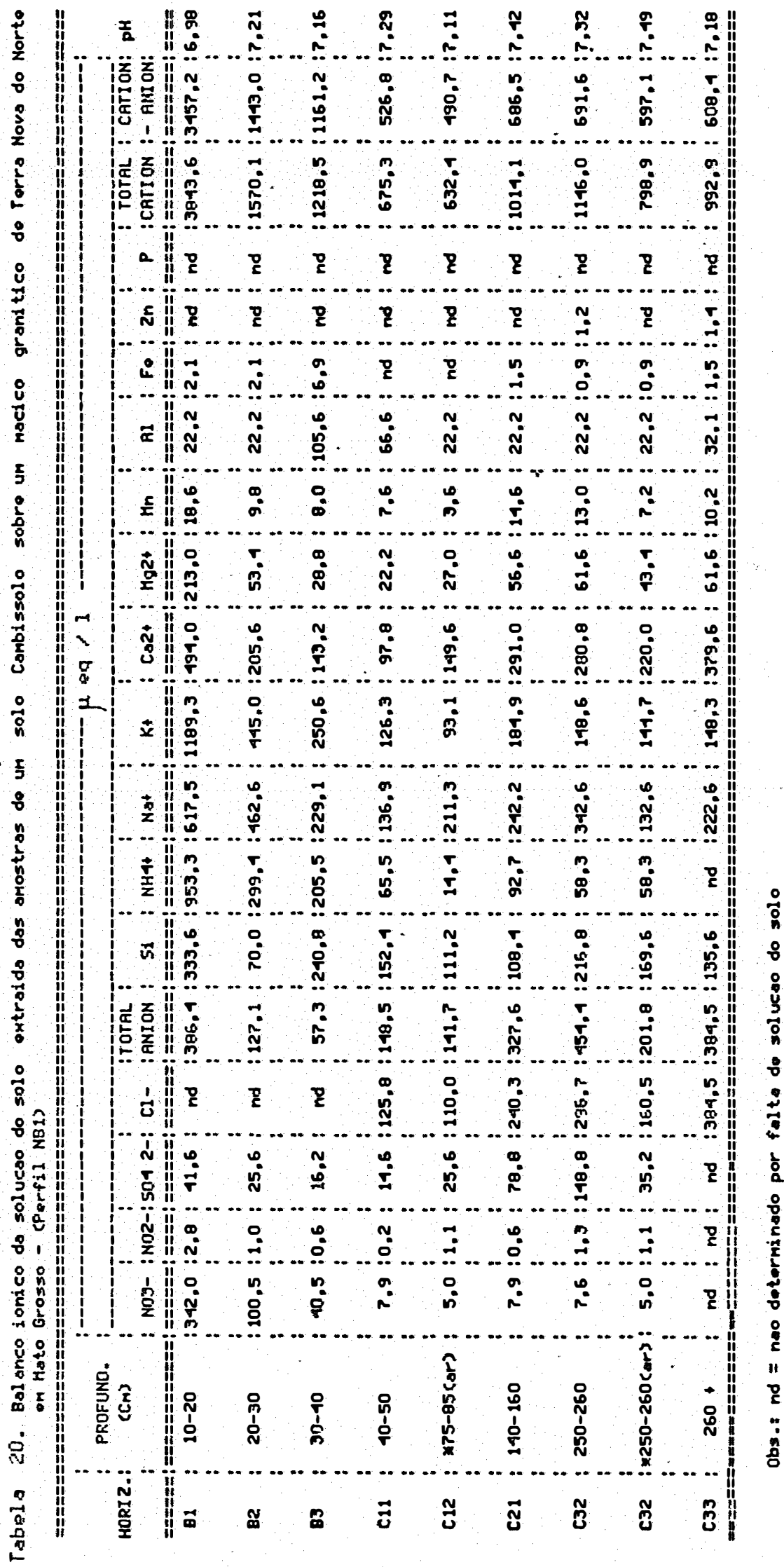


decorrencia da baika quantidade de solucăo obtida da sua amostra. O horizonte B1 (15 - 25cm) apresenta excesso de ânions e valor de $\mathrm{pH}=6,0$. Os demais perfis apresentam excesso de cations e valores de pH entre 7,24 e $7,54$.

A tendência verificada neste pertil NAl é pelo excesso de ânions no horizonte superficial Bi e talvez no horizonte A11 e A12, seguido pelo excesso de cátions a partir do horizonte Ba até a profundidade observada.

A Tabela 17 , mostra que o perfil apresenta excesso de ânions, desde o horizonte A11 ( 1 -m $5 \mathrm{~cm})$ até o horizonte Bi4 $(40-50 \mathrm{~cm})$. A quantidade de . ânions decresce significativamente em profindidade, até o horizonte B12 $(20-30 \mathrm{~cm})$ mas, a partir do horizonte $B 13$ (30-40cm) há um incremento significativo até o horizonte B14 $(40-50 \mathrm{~cm})$. A partir do hor izonte B22, verifica-se uma inversäo, passando a existir excesso de cations com tendência a incremento em profundidade, inclusive nos horizontes constituidos pela arena granitica amarelada. Com relacăo ao perfil NA3 näo foi possivel realizar o balanco iônico da solugäo do solo obtida a partir dos horizontes A1 até B3, em decorrência da pequena quantidade de solugáo extraida que impossibilitou a dosagen do NO3 que é o principal ênion, conforme demonstram os demais perfis. Assim sendo, o balango iônico realizado a partir do horizonte Cas $(95-105 \mathrm{~cm})$, (Tabela 19), demonstra 
- excesso de cátions até o horizonte observado C32 (220 240(m). Neste perfil, o excesso de cations tende a decrescer em profundidade. Dutro detalhe observado neste perfil é que os valores de pH näo são concordantes com os excessos de cátions, conforme se observa no perfil NA1.

Em funcão da năo disponibilidade da solucáo do solo dos horizontes superficiais do perfil NB1, o balanco iônico foi realizado a partir do horizonte B1 (10 - 20cm) conforme se observa na Tabela 20, apesar da falta dos teores do ânion cloreto. Percebe-se portanto, o excesso de cátions em todos os horizontes analisados, com tendência a decréscimos significativos até o horizonte Ci1 (40 - $50 \mathrm{~cm})$, e a partir dai, mantém-se com pequenas variagís até a profundidade observada.

En resumo, observa-se que 0 excesso de ânions ocorre nos horizontes superficiais, onde os teores de nitratos e ácidos orgânicos sâo bastantes elevados en decorrência do maior teor de matéria orgânica. dá o excesso de cátions ocorre nos horizontes mais profundos, onde os teores de nitratos e ácidos orgânicos são bem maisi reduzidos.

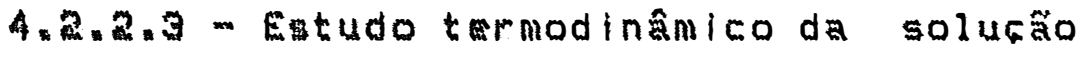 do solo.}

Neste item procurou-se aplicar un tratamento sob o ponto de vista termodinâmico no processo de neotormagão dos argilominerais no solo, 
utilizando modelos desenvolvidos por PEDRO (1969) E TARDY (1969).

Assin sendo, a partir das concentragies de $\mathrm{Ca}, \mathrm{K}$, Na, Sib2 e valores de pH da solugão do solo extraida das amostras de solo e arena dos perfis analisados, foram elaborados os diagramas de estabilidade dos minerais neoformados no solo, conforme demonstram as Figuras 54 a 57 , a partir dos logaritmos das concentragíes apresentadas nas tabelas de no. 21 a 24.

Os diagramas do perfil NA1, constantes na Figura 54, demonstram que a estabilidade das amostras se concentram na zona de estabilidade da caolinita. Isto indica, que as concentragíes dos ions ca, K, Na, Si e valores de pH da solugáo do solo do perfil NA1, condiciona predominantemente a neoformagáo do argilomineral caolinita. Ds diagramas também demonstram que as amostras analisadas condicionam una fase bastante estável à neoformagáo da caolinita, isto porque, náo se percebe nenhuma amostra direcionando à zona limitrofe da caolinita.

Com relacáo ao perfil NA3, observa-se através dos seus diagramas constituintes na Figura 56, que as suas amostras se concentram quase na sua totalidade, na zona de estabilidade da caolinita mas, adentrando também na zona de estabilidade da montmorilonita e da microclina. 

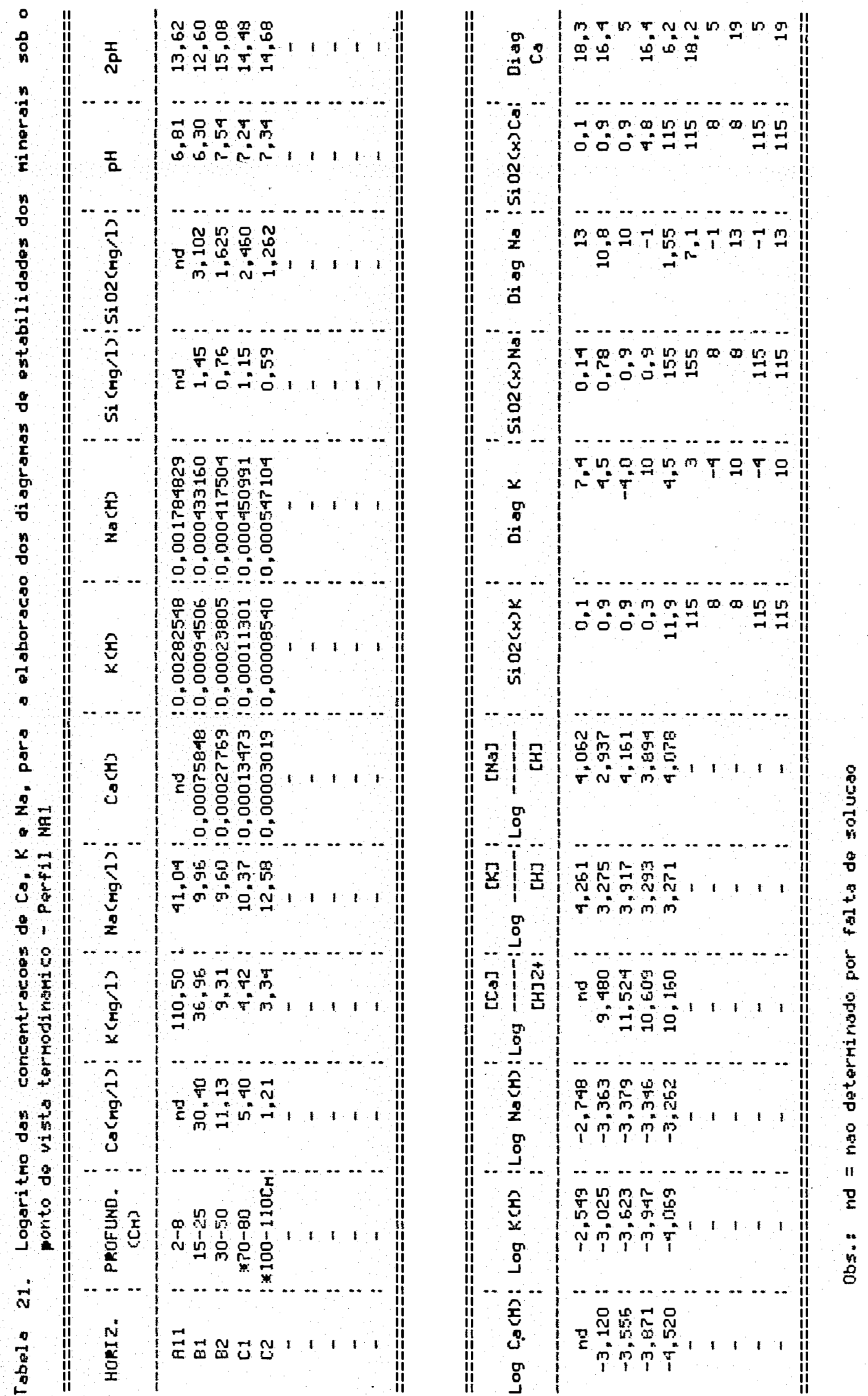

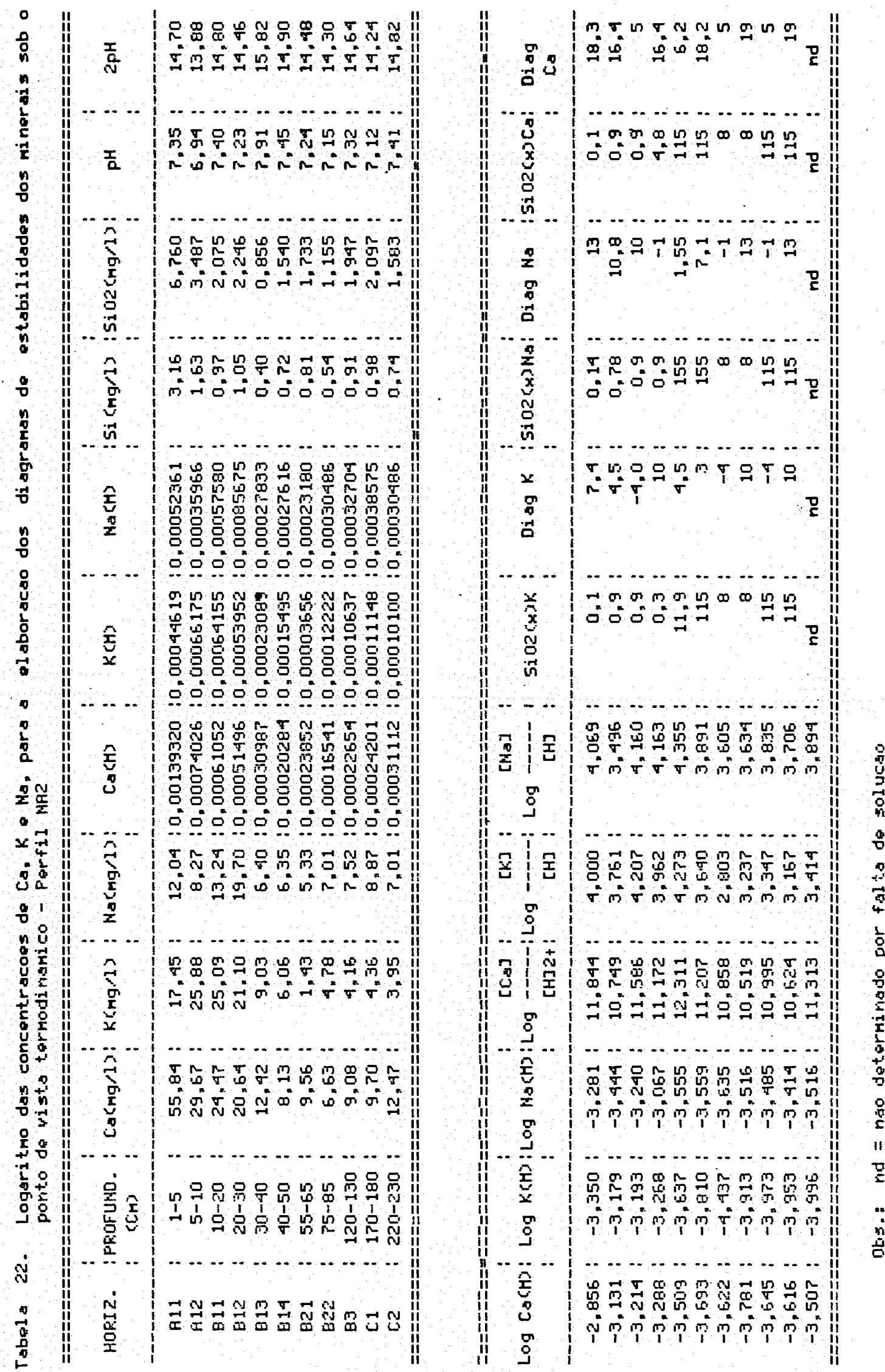

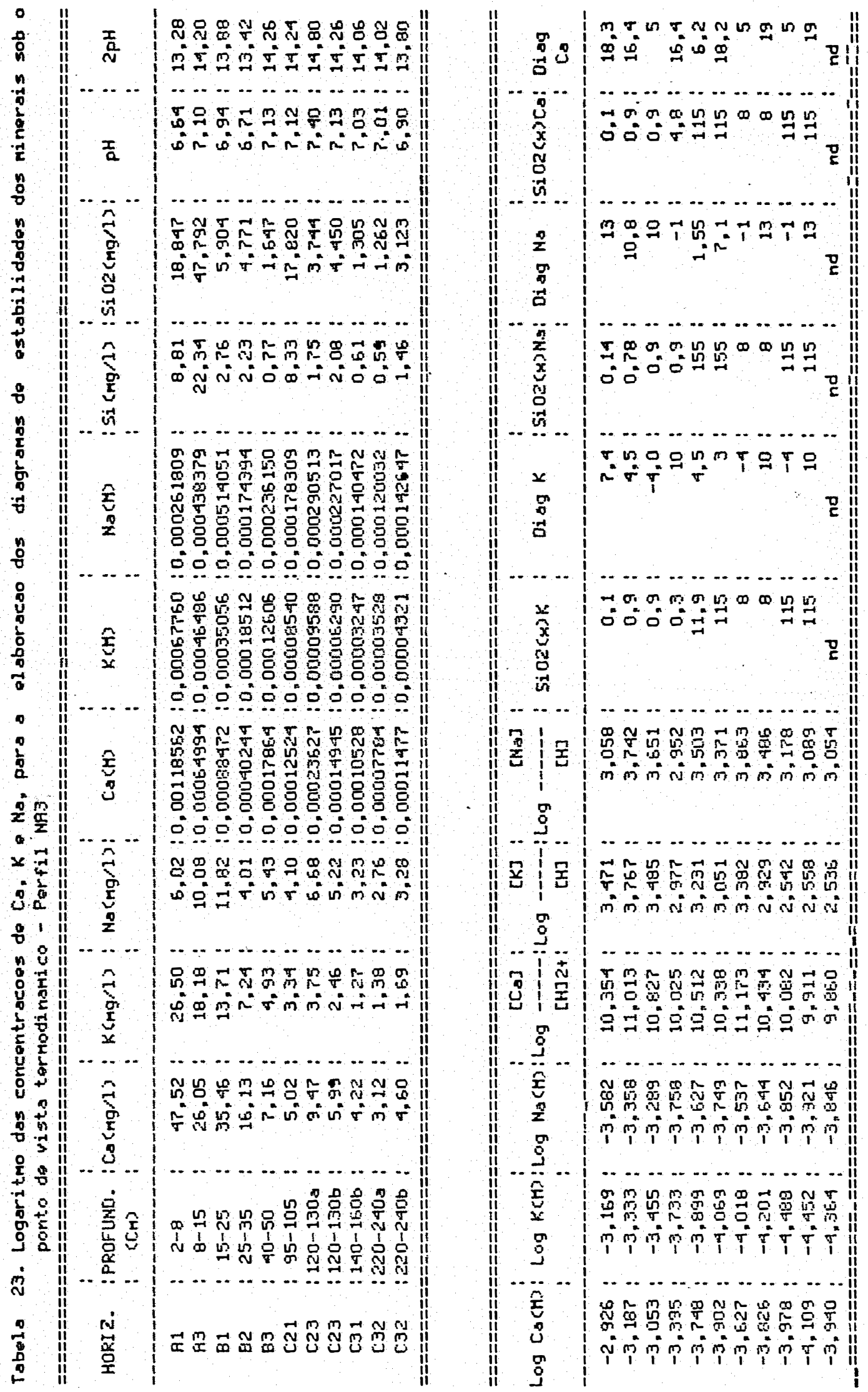

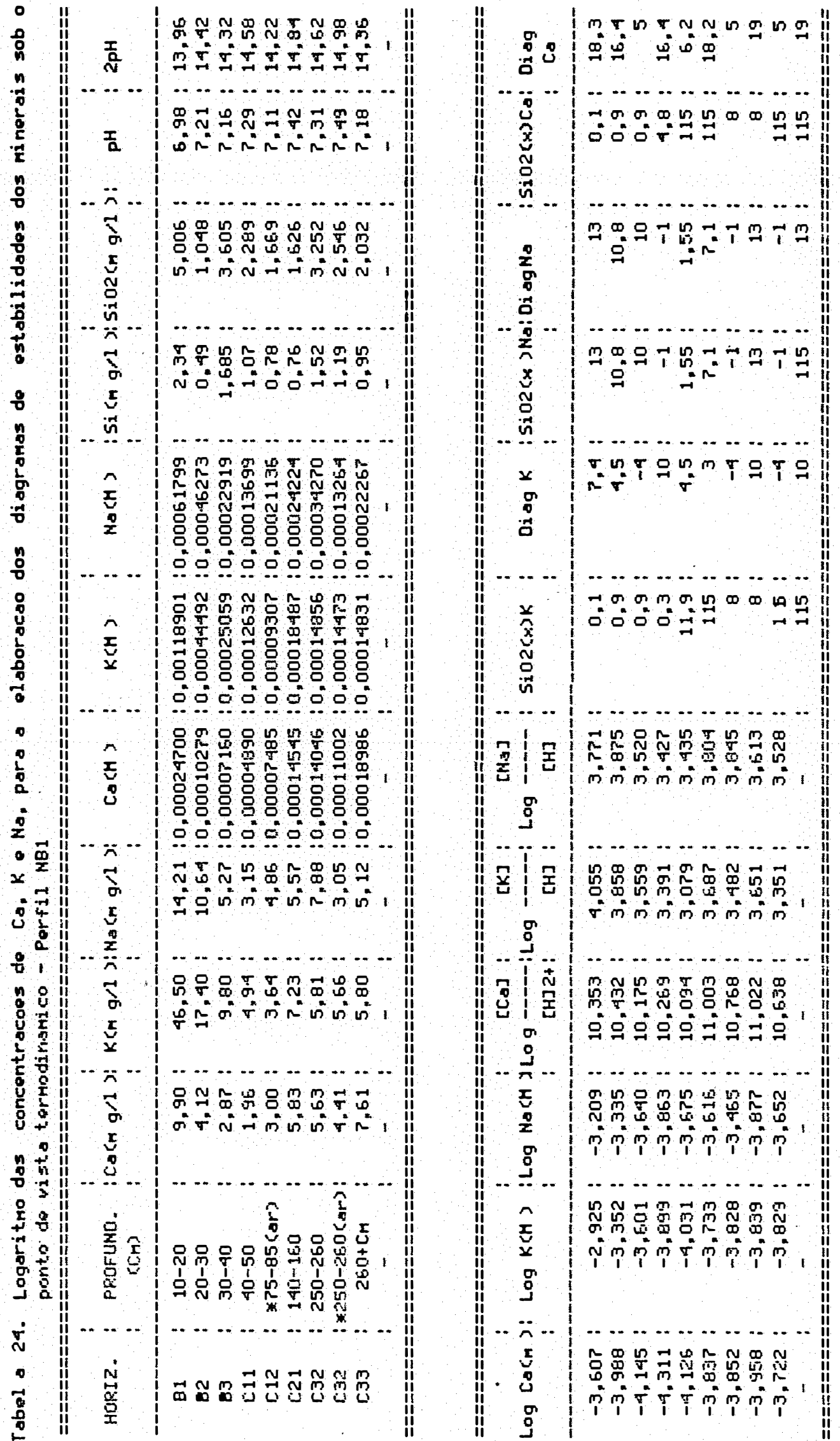

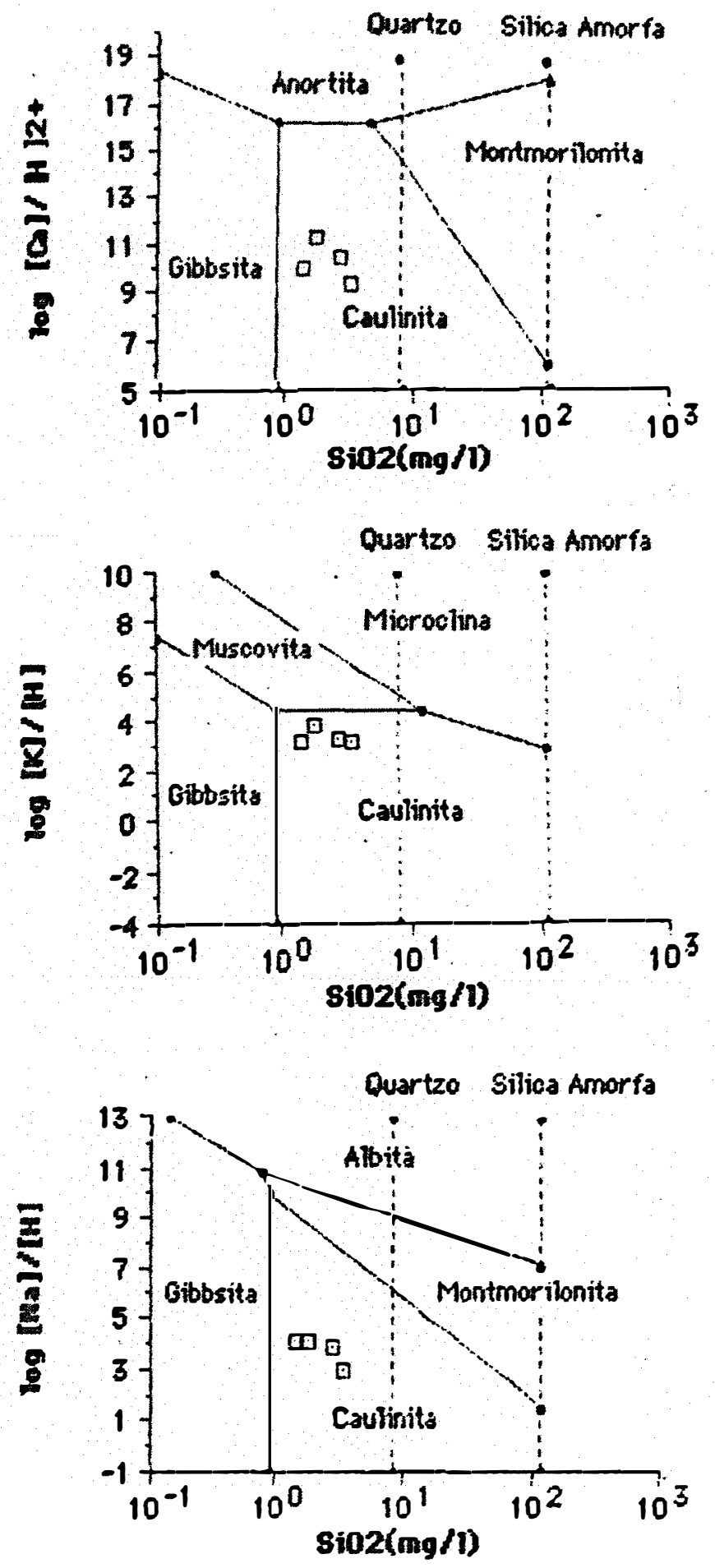

Figura 54 - Diagrama da estabilidade dos minerais neoformados en tuncäo da concentracăo dos ions Ca, K, Na E SiOz e valores de pH. 1 a $250 C$ e 1 atm, na solucăo de solo e arena de un solo cambissoIo - perfil NA1. 

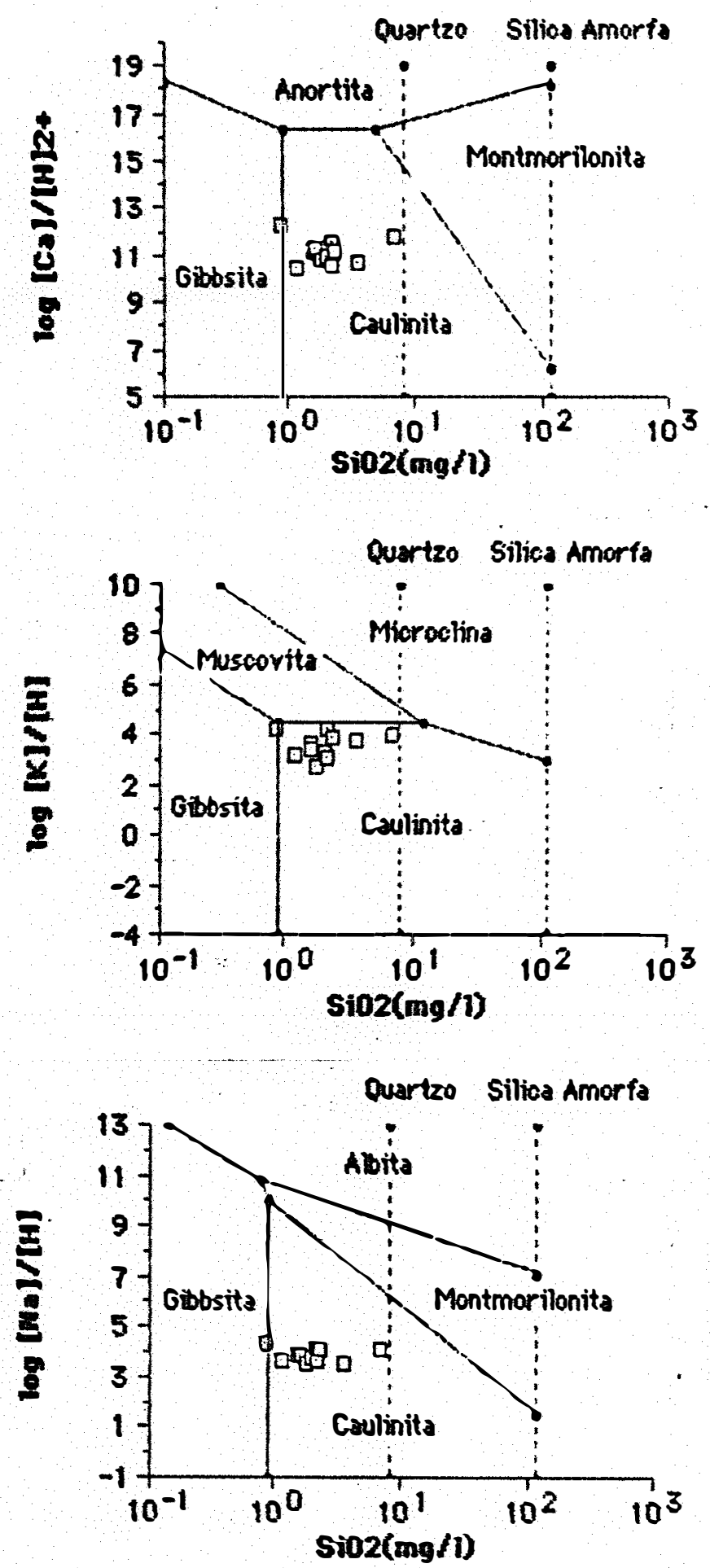

Figura 55 - Diagrama da estabilidade dos minerais neoformados en funçáo da concentracáo dos ions Ca, K, Na E Sidze valores de pH $\quad$ a $250 C$ e 1 atm, na solucão de solo e arena de un solo cambissolo-perfil MA2. 

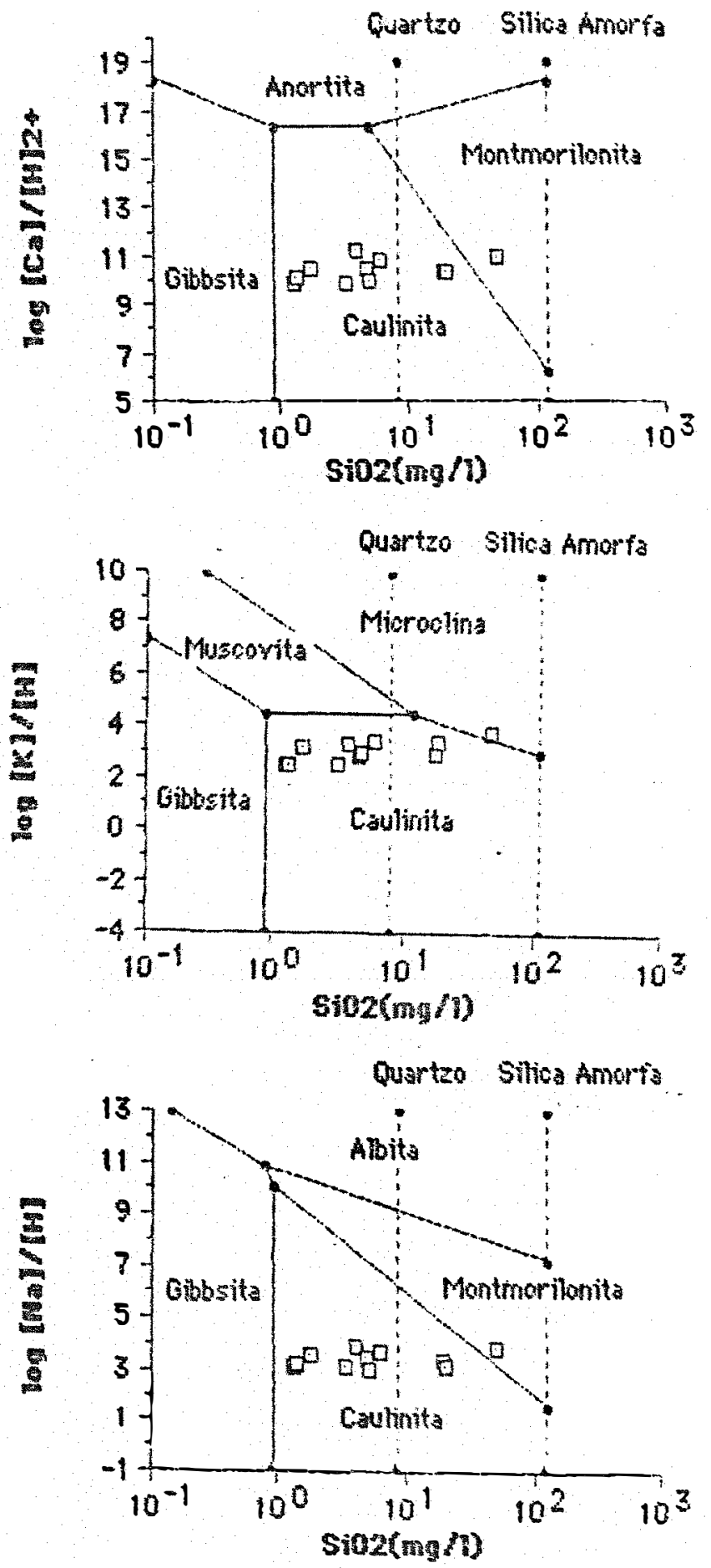

Figura so- Diagrama da estabilidade dos minerais neoformados en funcáo da concentraḉo dos íons Ca, K, NaESioe e valores de pH a a $250 \mathrm{C}$ e atm) na solucáo de solo e arena de un solo cambissolo - perfid HA3. 

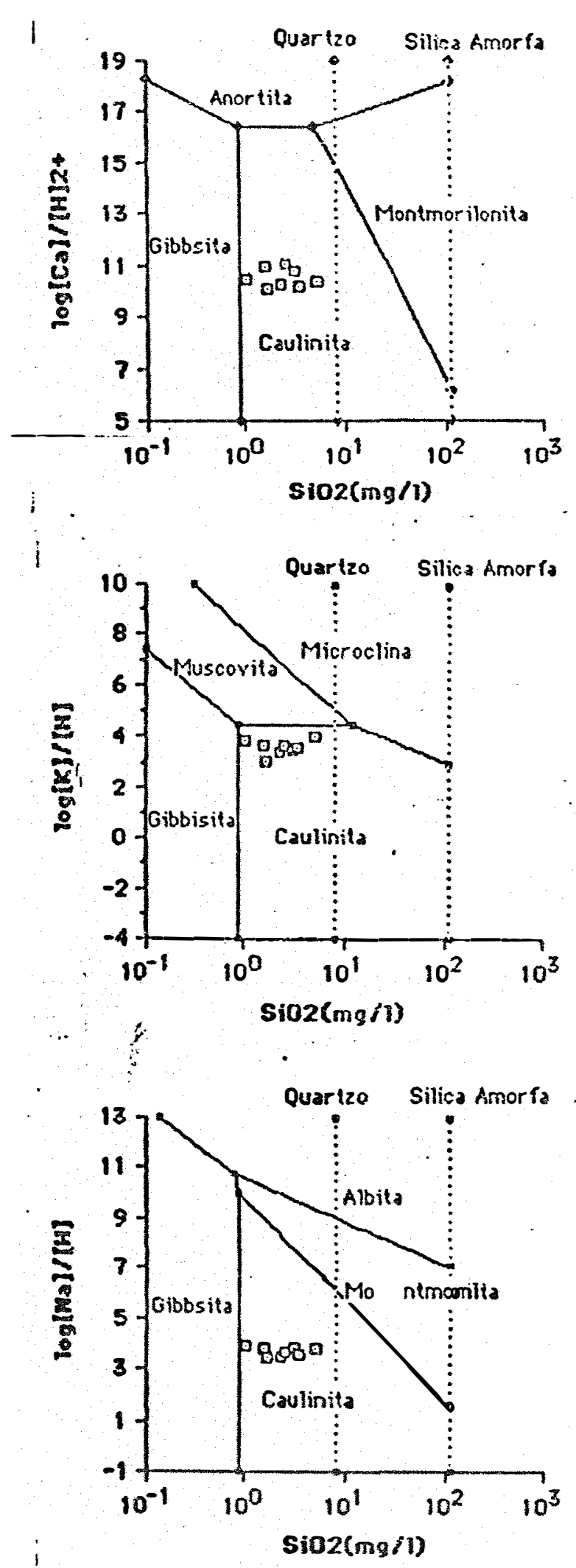

Figura 57 - Diagrama da estabilidade dos minerais neoformados en tungä́ da concentragáo dos ions Ca, K, Na e Sioze valores de phl a $200 \mathrm{C}$ e 1 atm, na solusăo de solo e arena de un solo cambissolo-perfil NB1. 
Este fato indica que as concentracies dos ions Ca, $K$, Na, si e os valores de pH da solucä́o do solo do perfil Na3, possibilita uma ampla faika de atividade dos seus ions abrangendo as fases, ou as zonas de estabilidade da montmorilonita $e$ microclina. Desta maneira percebe- se oue, apesar da caolinita se constituir numa fase bastante estavel neste perfil, a atividade dos seus ions proporciona tamben a neoformag ảo do argilomineral montmorilonita. Também, a atividade do ion potassio presente na solugäo do solo deste perfil, proporciona uma certa estabilidade do feldspato potássico que é a microclina. importante salientar que esses fatos né ficaram evidenciados nas análises por difratometria de raios $-x$.

LEPRUN et ali $i(1989)$ analisando a composicáo das águas de percolación de solos do Estado de Rondonia, concluiram que, apesar do intemperismo elevado dos solos sob condiḉs amazônicas, têm ảßuas com composicáo em equilibrio com a montmorilonita e näo com a caolinita como poder-se-ia pensar logicamente.

Os diagramas do perfil NA2. constantes na Figura 50 , demonstram gue as amostras deste pertil se concentram na zona de estabilidade da caolinita, no limite com a zona de estabilidade da gibbsita. Esta tendencia observada, significa que as concentrabies dos ions Ca, K, Na, Si e valores de pH da solugáo do solo das amowas do perfil rae, condicionam majortariamente a 
neoformaço do argilomineral caolinita e minoritariamence formacto da gibbsita, os seja, apesar da caolinita presente nas amostras do perfil NAz, constituir numa fase estável, a atividade dos seus ions extrapola o limite ou a zona de estabilidade da caolinita.

Os diagramas do perfil NB1, constantes na Figura 57 , demonstram que as amostras deste perfil se concentram na zona de estabilidade da caolinita, sendo que, apenas uma amostra se posiciona no limite com a zona de estabilidade da gibbsita. Esta tendencia idêntica a do perfil NA2, significa que as concentragies dos ions Ca, K, NA, si e valores de pH da solucáo do solo das amostras do perfil NB1, condicionam majoriteriamente a neoformaç̃o da caolinita s minoritariamente à formaço da gibbsita. Assim sendo, apesar da caolinita presente nas amostras do perfil NB1, constituir numa fase estavel conforme demonstra os seus diagramas, a atividade dos seus ions atinge o seu 1 imite, apresentando portanto, tendencia à gibbsitizaço.

Esses diagramas confirmam de fato as análises mineraligicas da fase solida das mesmas amostras, as quais foram realizadas através da difratometria de raios - - . Os difratogramas mostram picos bem acentuados da caolinita e picos mais fracos da gibbsita.

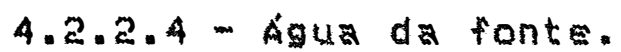

$$
\text { Neste item seráo apresentados }
$$


resultados referentes as analises da áglua de uma nascente localizada no sopéda encosta e entre as duas vertentes estudadas. Ds teores dos ions identificados e dosados, säo os seguintes:

\begin{tabular}{|c|c|c|c|c|c|c|c|}
\hline NO3 & $=<$ & 0,01 & $/ 1$ & $F E$ & $=$ & 0.07 & $n+g / 1$ \\
\hline NOE & $=<$ & 0,01 & " & $2 n$ & $=<$ & 0,02 & * \\
\hline 504 & $=$ & 3,81 & $"$ & $p$ & $m<$ & 0,01 & " \\
\hline $\mathrm{Cl}-$ & $=$ & 0,26 & $"$ & $A B$ & $=r$ & 0.05 & * \\
\hline $5 i$ & $=$ & 14,69 & $"$ & B & $=<$ & 0,02 & * \\
\hline $\mathrm{NHA}$ & $=<$ & 0,20 & * & Ba & $m$ & 0,06 & $"$ \\
\hline $\mathrm{Na}$ & $=$ & 4,39 & $"$ & $\mathrm{Cd}$ & $=<$ & 0.02 & " \\
\hline K & $=$ & 2,96 & " & $\mathrm{Cr}^{r}$ & $=<$ & 0,05 & $*$ \\
\hline $\mathrm{Ca}$ & $=$ & 1,44 & $"$ & Cus & $=6$ & 0.02 & $=$ \\
\hline$M g$ & $=$ & 0.18 & " & $P b$ & 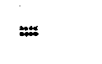 & 0,11 & - \\
\hline$M n$ & $=<$ & 0,01 & $\cdot$ & $\mathrm{Ni}$ & $=<$ & 0,02 & $\cdot$ \\
\hline Al & $=$ & 0,53 & - & & & & \\
\hline
\end{tabular}

Os ions nitrato, nitrito e amônio săo encontrados na ägua da fonte con teores bem abaiko dos valores minimos dosaveis, contrastando significativamente con os seus teores na solucáo do solo.

$$
\text { Com relagáo ao ion sulfato, o }
$$

seu teor na áglua da fonte de $3.81 \mathrm{mg} / \mathrm{l}$, sendo portantó superior aos seus teores médios determinados na so3ugäo dos perfis NAI E NBI.

0 ion cloreto dosado na água da fonte apresenta teor igual a 0,26 nig/l, sendo portanto ben interior en relacáo à suas médias dosadas na solucăo do 
solo de todos os perfis anal isaros.

o teor do ion silicio na água da fonte é de $14.69 \mathrm{mg} / \mathrm{l}$, sendo portanto bem superior às suas médias determinadas na solucäo do solo extraida dos solos que constituem os perfis NA1, NA2, NA3 E NB1. Tal fato constitui prova cuanto a sua remogáo pelo fluxo lateral da água.

0 ion sódio dosado na água da fonte apresenta o teor de $4,39 \mathrm{mg} / \mathrm{l}$, sendo portanto. superior à sua média determinada na solufä́o do solo do perfil NA3, mas inferior às suas médias na solugáo do solo dos perfis NA1, NA2 e NB1. Este fato refiete a sia alta mobilidade e lixiviagăo dos perfis de alteragáo.

- teor do ion potásio na água da fonte, apresenta o valor de $2,96 \mathrm{mg} / 1$, sendo bem interior às suas médias determinadas na solucăo do solo de todos os perfis analisados.

0 ion cálcio dosado na água da fonte apresenta o teor de $1,47 \mathrm{mg} / \mathrm{l}$, sendo portanto, bem inferior em relacáo às suas médias determinadas na solugáo do solo de todos os perfis analisados. Este fato reflete bem a sua alta retengáto e baixa mobilidade nos pertis de a l teraciono.

0 teor do ion magnésio na água da fonte apresenta o valor de $0,18 \mathrm{mg} / \mathrm{l}$, sendo tambem, bem inferior às suas médias determinadas na solurgo do solo de todos os perfis analisados. Tal fato, tambem reflete a sla baixa mobilidade no perfil de alterafäo devido a sua 
retengáo pelo complexo de troca.

Con relacăo ion aluminio: o seu teor na água da fonte é de $0.53 \mathrm{mgll}$. sendo portanto, superior aos seus teores médios determinados na solucäo do solo dos perfis NAl, NA2 NB1, mas, inferior à média do perfil NA3.

Os ions manganess, ferro, zinco fosforo, apresentam teores< $<.01,<0.07,<0.020<0,01$ respectivamente: sendo portanto, walores bem inferiores às suas medias determinadas na soluço do solo dos perfis anal isados.

Qs demais ions dosados na água da fonte apresentam também valores muito baixos e nä ha possibilidade de comparar com os teores da solug dois perfis analisados pois, os mesmos näo foram determinados na solutäo do 5010. 


\section{W CONGLUt}

A interpretacäo dos resultados obtidos neste trabalho, permite apresentar as seguintes conclusies:

- o guartzo o mineral dominante na rocha, arena e solo; aparece em gräos isolados, com alguns aasos de geminacăo devido ao agrupamento de vários gräos de quartzo cada um com orientacáo bica diterente. No solo e na arena näo se percebe modificacios químicas nos cristais de martzo, mas percebe-se sua desagregacáo fisica através do processo de fraturamento, tornando-os menores. o processo de fissuracio também é evidente em alguns cristais do quartzo, favorecendo a importacáo de bidos de ferro nessas fissuras;

- os grä́s de quartzo ocupam normajmente $70 \%$ do volume dos esqueletos e näo apresentam indicios de remanejamento ou transporte;

- a microclina apresenta no inicio da sua alteractio am profundidade, a formagóo de sericita dispersa num gel de coloracio escuro, geralmente no centro do cristai;

* eni consequencia do inicio da alteracio en profundidade os plagioclasios apresentam a tormacáo un gel escuro no centro do mineral, denotando a formacáo da sericita e epidoto, sendo este, em menor proportáo a da ser:cita;

- a biotita apresenta em quantidade ben inferior à dos feldspatos. Seld minerais intactos na rocha, 
apresentam coloracäo marron escuro, enquanto que na arena solo arresentam coloraténo vermelhowamarelada;

- a presencia da microclina até nos horizontes superficiaise a dos plagioclasios a partir da profundidade de 20 a $30 \mathrm{~cm}$, assim como, teores de silte de ate $40,2 \%$ denotam que os solos analisados sfio poucos evoluidos em funcäo do rejuveneseimento proportonado bela erosäo laminar, facilitada pelo modelado montantoso das duas topossequencias.

- todos os pertis analisados apresentam aumento no teor de argila em profundidade sem contudo apresentar gradiente textural que caracteria solos com hor izonte B textural;

- a estrutura bastante forte e bosa do solo na faixa de we a 110 cm do pertil dae se deve a sua textura argilosa e a alternância de unedecinento e dessecacto;

- a diperenca demasiadanente elevada no grau de Floculatio nos perfis analisados é atribuida à prasa argila coloidal nos hor izontes mais protundos e a materia organica noe horizontes superficiais;

* a formacio acentuada de microagregados caracteristicas dos oxissolos, na medida em que se aprotunda nos perfis HA2 e NA3, se deve a intensiticasáo no grau de floculacáo das argilas;

$$
\text { - os pertis estudatos apresentam }
$$

caracteristicas desolos cambissolos com carater distrofico 
e a lunas variages em termos de evolus

- valores de 2,5 a 2. d de densidade real denotam que esses cambissolos säo dominados pela farăo areia;

- as migrab̧es das substancias himicas se processam em profundidade, atingindo os forizontes nais profundos, mesmo diante da pouca permeabilidade da arenai

* as amostras superticiais da fraráo si?te demonstram nos ditratogramas de raios - $x$, picos acentuados que denotam a dominancia do quarzo. masanto pue nas amostras de protundidade, seus picos se calparan com os da caolinita egibbsita;

- os difratogramas de raiog ... $x$ da fracáo argila das amostras de solo arena desses cambissolos apresentam picos bem acentuados de caolinita e piods mas fracos de gibbsita, indicando a dominancia da caolinita, como também denota a homogeneidade bastante sevada do mater a d de partida nas duas topossendencias NA e NB;

- os altos teores dos lons nitrato e amonio na solucro do solo dos horlaontes superficiais desses cambissojos demonstram a ports atividade da biomasaj.

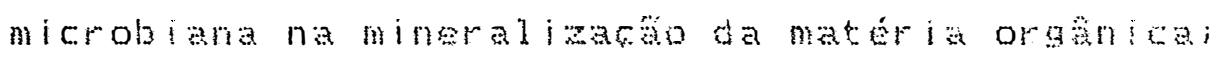

- a solucão do solo desses cambissolos é rica em cations mono e bivalentes, conferindo desta maneira, valores de pH neutro nos horizontes superificiais e I geiramente aloalino nos hor jzotes ma is profunos;

- a distribuifáo em profundidade, dos teores de ions da solucáo do 5010 extraida das amostras de 
5010 e arena desses cambissolos, reflete a atividade da biomasa microbiana na superpicie do solo a acto do intemperismo nos horizontes da arena e do granito em alteraction

- os íng sod, si, Al, fe da solutado do solo apresentam nisidas evidencias das suas migrabos promovida pelo fluxo lateral da água;

- os maiores teores de Na ek da solua do solo do perfil NAt denotam o fornecimento at ivo desses ions a parcir da alteracáo dos feldspatos do granito subjacente;

- a solucöo ro solo extraida das amostras desses cambissolos apresenta teores de het, Kt, Nat, sion e valores de pil ase propiciam a neotomafón de argilominerais que se concentran na rone de establidade da caolinita com alguma tendencia à zona de estabilidade da gibbsitan

- a neotormaca de arg i $30 \cdots$ mineral na zona de estabilidade da montorilonita obsemata no perfi 1 Nas, se deve ao acimblo expressivo do silicio, propor ionado pelo san pluxo lateral ocorido na vertonte wa 


\section{LITERATURA CITACA.}

BECKWITH, R. S. R REVE, R. - Studieg of golut Ie silica in soids: I. Autt. J. Soil Res. 1:157‥168,1963.

BLAKE, G. R., 1965 - Particle density. Bulk densits. In: C.A. BLACK (ed, "Melods of soil analysis, Madison, Wise- American sociaty of Agronoms, pp. 37 - 390 (Agronoms, 9).

BONNEAU, H. EOUCHER, B. - Constituants et proprietes du sol. In Pedologie. Kasson Editeur - Paris, New York, Barcelone, Milan, f.979.

BREWER, R. Fabric and mireral Rnalysis of soils. John Wily gons, Wen York, 1964.470 p.

BRAOY, N. C. - Nabrea e proprledades dos solos ga. Edigo. Livar a Freitas Bastos S.A. 4979.

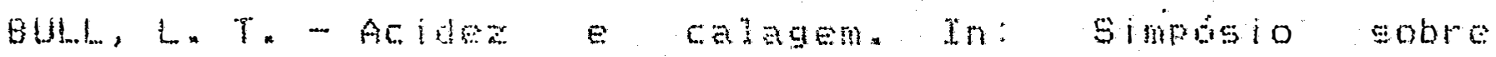
interpretacäo de andise quimica de solo e planta para

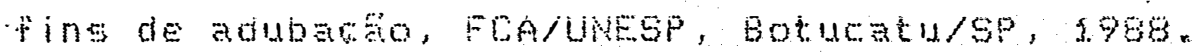
BULLOOK, P.; FEOROF, In; JONGERUS, A.; sToOps, o. TURSINA, T. "Handwook for soil thin sertion

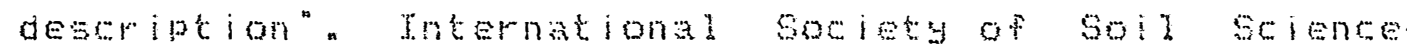
$(\operatorname{sen} d a t a)$

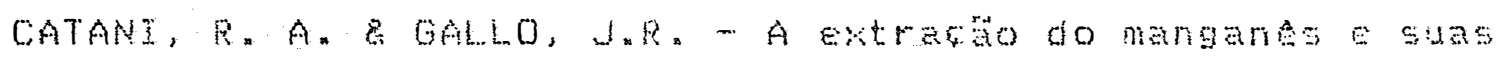
formas de ocorrencia en alsuns solos do Esado de säo Pas1o. Bragantia, Campinas, 19:225-266, 1951.

CERRT, Co. - Contribuiga ao estudo das arenas grantelcas - Caracierizacăo minerabóca e qúmica de una

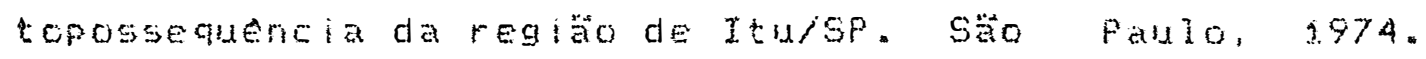




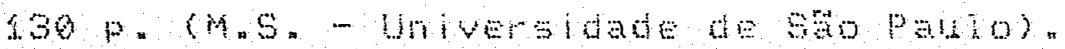

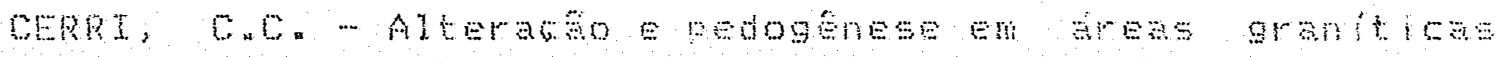

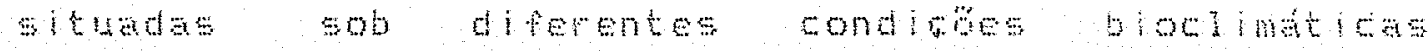

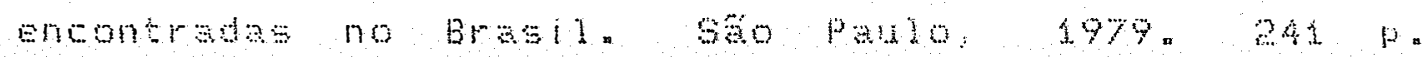

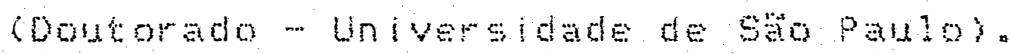

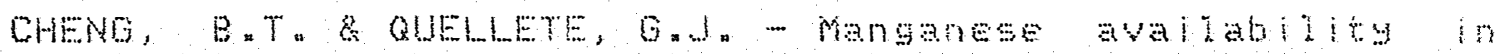

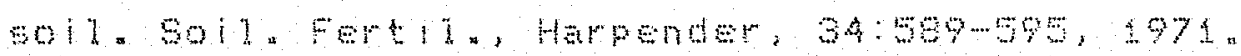

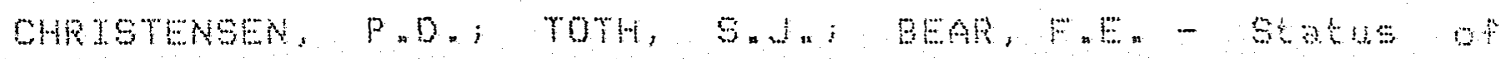
sol1 magnese as intluenced bs matotare, organt mater

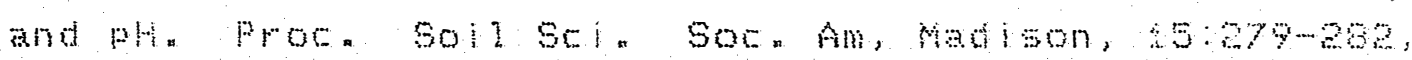
1900.

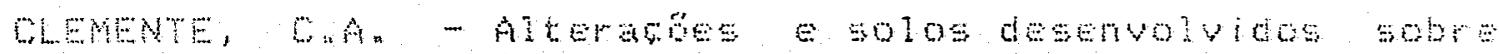

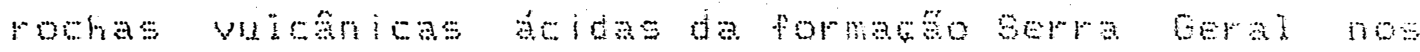

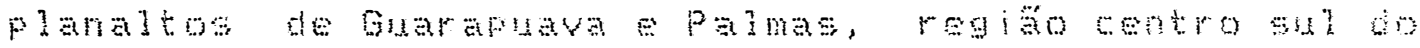

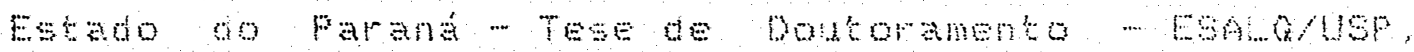
Piracicaba-se, 1908.

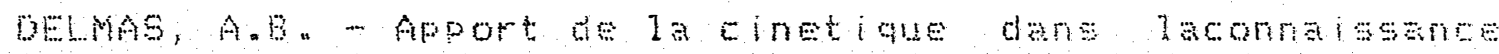
dos phenomense d'ateration. So iencedi sol, 2-3, p. $125,136,1979$

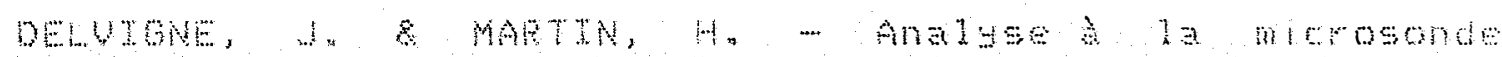

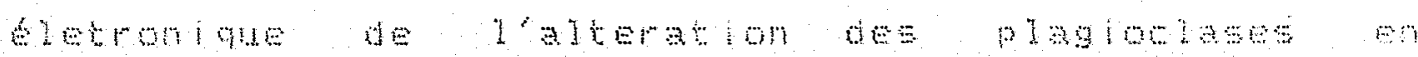

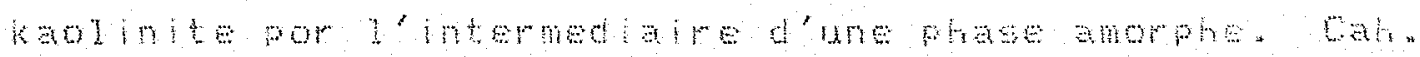

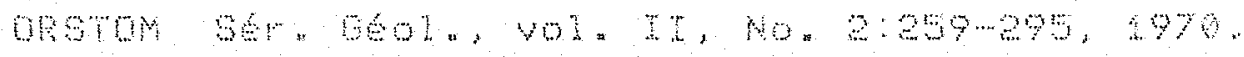

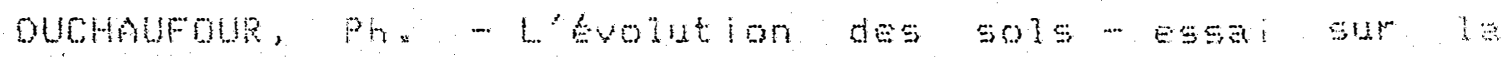

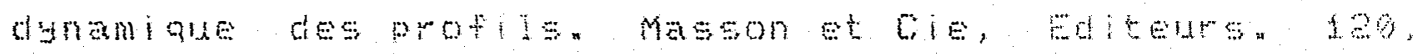
Bonkevard sant - Geranin, paris. 1968.

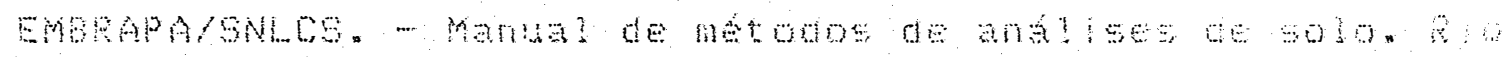
de Janeiro, Mintsterio da Agricultura, f979. 
FELLER, C. - Une methode de fract lonnement granulonetrique de 1 a matífe organique des sols. Application aur

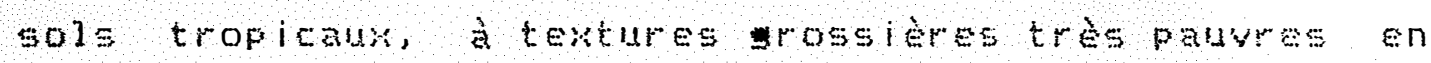
hums. Cahiers. okstom, ser. Pedol., vol. XUITI No. 4. Paris, 197\%.

FUJIMOTO, C.K. \& SHERMAN, G.D. - ThE EttECt of drying, heating and evetting on the level of exchangeable in Mm in Harvatian soils. Proc. Soil Soi. Soc. Am., Madison, 10:107-19, 1945.

GIFFORD, R.D. \& FRUGOLI, D.F. - SIIIEA SOURCEs in sOI solution. Nature $145-386-368,1964$.

HARRIS, R.C. \& ADAMS, J.4.S. - GeOREmical and mineralogi cal changes in the weather ing of aranite rochs Amoriban Journal of science 264, $146-173,1966$.

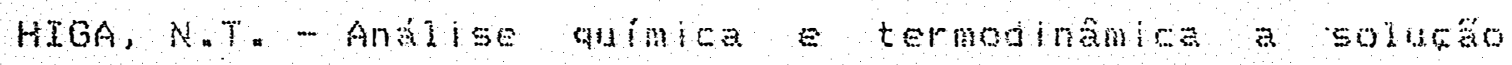
de um 5010 cambissolo sob flomasa Amánica num macioo granitico de Terra Nova do NorbemT In "XxI congresso Brasileiro de Ciencia do $5010^{\circ}$-Camplnas/Sp-10 a 25 de Whito de $198 \%$

JACKSON, ML. -.. 5011 chenical analysis. Aduanced course. end Edition, 7 Therinting publ unive of bseonsin. Madison, $1969,896 \%$

KHANNA, P.K. \& MISHRA, B. - Behaviour of manganese in some acid soil in western germang in relation to ph and air - drying. Geoderma, Ansterdan 20:289.297, 1979.

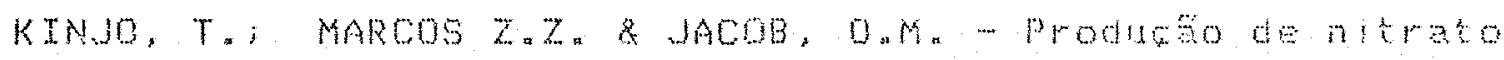
por incubacáde de zmostras do horizonte Ap. desolos da 
regiäo canavieira de piracicaba. Revigta Brasileirade CiEncia do Solo U.2, MaiolAgosto w9\%8.

KRONBERG, B.I.; FYFE, W.S.; NESBITT, H.W.; MEIFI, A.J. Kinetics and geochemistry of weathering. Tn procedings from II International seminar of Lateritisation Processes, 1982.

KUPPER, A.; SACCHETTO, M.T.O.; RAIJ, B. vON - formas E niveis de manganesen alguns solos com sem calagem. Bragantia, Camp inas, 27:xy - xury (Notab), 1968.

LENOS, R.C. \& SANTOS, R.D. - Mandal de deserigaro coleta de solo no ampo. SBCS/SNLCS - 2a. edicko. Campinas 1934.

LEPRUN, JCH; SANTOS, R.B.; CERRI, C.C. - COMPOSigódas águas de percolacáde solos do Estado de Rondinian Geochinica Brasiliensis, 3(1): $23-31$, 1989

Malavolta, E. - Manual de quimica agricola. Editora Agronomica Ceres LTDA. Säo Paulo, 1976.

MCKEAGUE, J "A. R CLINE, M.G. - Silica in soil. Adun Agron. $15: 339-396,1963$

MCKEAGUE, J.A. \& CLINE, H. G. - Silica in soil solition. I. The form and concentration of dissolved siliea in aqueous extracts of some soils. Can. Ln soil soi, 43:70... $82, \quad 1963$.

MELFI, A.J. - Intemperismo de granitos e diabasios do municipio de Cama inas e arredores, Estado de Sáo patoSP - 1967. 166 P. (Doutorado FFCL-USP).

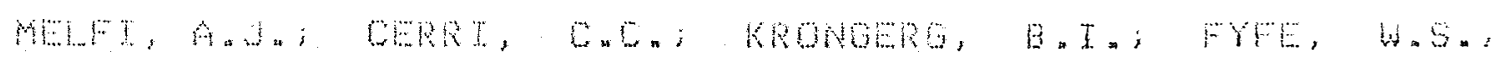
McKINMON, 8. -... Granitic weathering: a Brasilian study. 
Journal of soil seience, 34, p.811-951, f983.

MELFI, A.J. \& CERPS, C.C. - Contributgo ao estudo da alteracá superficial de rochas graniticas … Evoluca dos feldspatos para ninerais do grupo da saolinita através de uma fase amorfa. Anais do XXuII congresso Brasileiro de Geologia. Porto Alegre $27,0.39-47,4974$. MrLteER, F. - Physical, chenical and mineralogical properties related to the micromorfology of the Cantield sita Loan a Fragindalt. Phob. Dissertation. Ohio State University, 161 $p=1965$.

MISRA, S.G. \& MISHRA, P.G. - AVailability of in as effected by carbonate addition. P1. Soil, Hague, 30:290$298,1969$.

MONJZ, AnC; BUOL, S.W. \& WEERD, S.B. Formation of an oxiso! - Ultisol transition in säo paub, Brasil: IT. Lateral dinâmics of chemical weathering. Soil Seience Sor. Am... Vol. 46, 1932.

MLURAOKA, T.; NEPTUNE, A.M.L.; NASCTMENTO FILHO, U.F. .. Ava! iago da disponibilidade de zinco e de manganes do solo para o feijoeiro. II. Manganes. Revista drasileira de Cisncia do Solo. Campinas, 7:177-182, 1983.

NINER, E. - A I Matologia do Brasil. SUPREN-IBOE, Rio de Janeiro, $197 \%$

NOVIKOFF, A.; TSALLASSON, G.; GAC, J.Y.; BOUROEAT, F.;

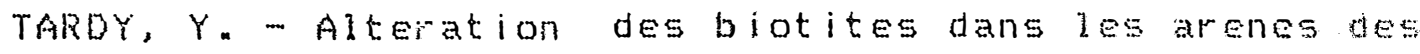
pays temperes, tropicaux et conatoriaw - tr. $6601.0411 ., 25,4: 287-305,1972$ 
PACES, T. - Steady state kinetics and equilibrium between gronduater and granitic roch. Geochimica et Cosmoenimica Acta " 37, p.2641-2663, 4973 .

PAGE, E.R. - Seudies on soil and plaut manganese. II. The relationiship of soil - BH to manganese avaibability. P1. Soil, Hague, 16:247-257, 1962.

PAUAN, M.A. R MIYAZAWA, M. - Disponibilidade do manganes no solo; dificuldades e problemas na interpletacto da analise para fins de fertilidade. Revista Brasileira de Ciencia do Solo. Campinas - Sp. U.8 No. 3, p. 289-2.298, Set. /Dea. 1984.

PEDRD, Gn - A alderabóo das rochas en condibes superticiais (perimorismo) - caracterizacto geomuimica dos processos fundamentais. Traduga do fololpho Jose melpi. Noticias Geomorfologicas, Campinas, g ify, winho 1969.3 a 140.

PROJETO RADAMBRASL. -- Levantamento de Recursos Naturais. Folha scol Juruena, pio de Jameiro, ministerio das Minas E Energia, 1900.458 p.

RATd, B. Van - Avaliara da fertilidad do solo. Instituro da Potassa of Fostato. Piracicaba - sp, setembro-198. RAIJ, B. van - Fóforo do solo. In: Simposio sobre interpretacán de andise quimica de solo e planta para

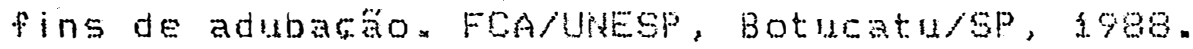

RAIJ, B. van \& CAMARGo, O.A. - Síbica solvivel en solos. Bragantia Vol. 32, Campinas, Julho/4973.

RETCharot, K. - Capacidade de campo. Revieta Brasileira da Ciencia do solo. Campinas ... sp. V.12, wo.3, p. 211 = 
23., set./des. 1988.

RETCHARDT, K. - Processos de transferencia no sistema solo-

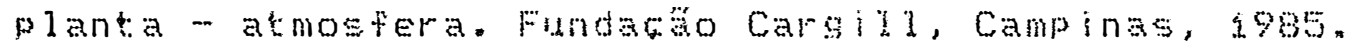
REICHARDT, K.; LIBARDI, P.L.; MEIRELLES, N.MF.; FERREJRA, H.F.F.; ZaGarto, EnAng; MATSUI, E. Extragăo e analise de nitratos em soluczo do Solo. Revista Brasileira de Ciencia do solo. Campinas -. SP. U.1, tos. 2.3 malo/dez. 1977

ROBERT, M. -- Etude Exper imentale de la desegregation du granite et de l'evolution des mira:. These sei. Paris, 1940.1970

RODRTGUES E STLUA, F.B. - OS Cambissolos da porgäo centra! da provincia estrutural da Mantiqueira e suas, relaros com os latossolos: alteracáo e pedogenesen " oăo paulo. 1980. 261 p. (Doutorado - Universidade de sao pabio).

RODRIGUES, T. E. - Caracterizasaro e genese dé solos Branos do macico alcalino de pocos de caldas (Mo). Tese

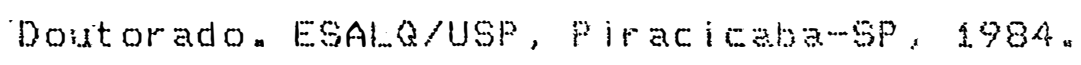

ROSOLEM, C.A. -.. Interpretasádos teores de bases trocaveis do solo. In: Simprisio sobre incerpretaco do andise quimica de solo e planta para pine de adubago. FCA, UNESP, Botucatusp, 1988.

SCHUYLENBOfGH, J.Van. - Weathering and sol tw forming process in the tropics. In: UNESco. Soils and tropical Weathering. Proceedings of the Bandung Symposium - 16 to

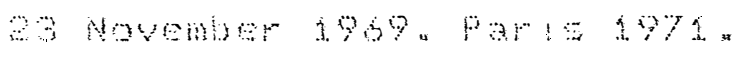

SIQUETRA, J. 0. R FRARCO, A. A. - Biotacnologia do 50lo- 
fundamentos e perspectivas. MEC - ESAL - FAEP - ABEAS. Biasilia-DF, 1988.

SoUza, En C. A. - Micronutrientes do solo. In: simpósio sobre interpretarbo de and lise quimica de solo e panta para fins de adubaga, FCA UNNESP, Botucatu/SP, 1988.

TARBY, Y. - Geochinie des alterations - etude des arenes et des earu de quel ques massifs or istallins d'Europe et d'Afridue. Memoires du Servieg de la Carte Geologique d'Alsace er de lorraine No. 31. Universite de Strasbours. Strasbours, 1969. 1990.

TARDY, Y.; BOCQUTER, G.; PAQUET, H.; MJLLOT, G. - Formation of clay from granite and th distribution in relation to climate and topography. Oeoderna 19, 19\%3.

VETTORI, L. - Metodos de analises do solo. Rio de Janeiro. Epts, 1969. 34 p. (Bolesim Técnico No.7).

UTTTI, O.C. - Enxofre do solo. In: Simpósio sobre inter pretarăo de analise quimica de solo e planta para fing de adubaço, FCA UNESP, Botucatu/SP, 1988. 


\section{APENDICE.}

\section{1 - Caractaristicas Morfológicas}

Topossequentin NA

- Deserisco geral

Perili NÁ

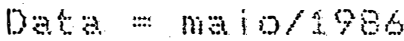

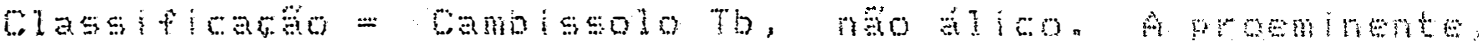

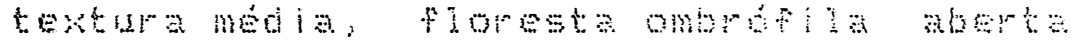
tropica?, reloro forte ondulado, waberato atsito.

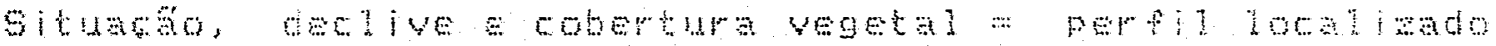

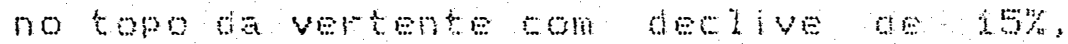

Altitide $\quad 200$ a 900 metron

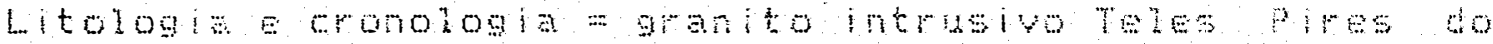
Grupo batam, prewamprano bugror.

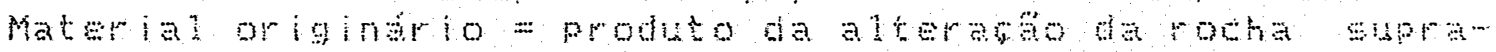
citada.

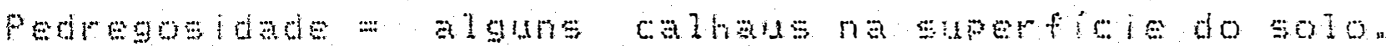

Rochosidade = varios matabes ne surfele do solo.

Pelevo local = montanhoso.

Relowo regional form ondulato.

Erosea = laminar ligeira.

Drenagsin $\quad=$ ben drenado

Ueo atual = nentwin.

Clina = Am (Koppon) - olma equatorial quente intos.

- Descrigádorfoligica

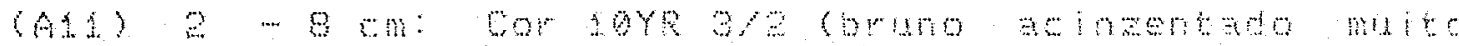
escuro, 43, s\% casalho, bo,

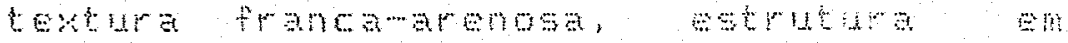

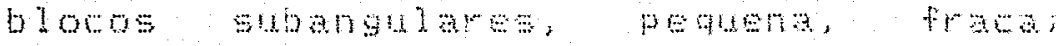
mitos poros pequens consistenela

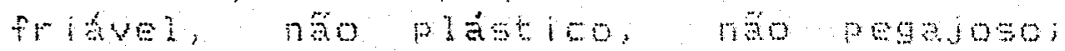

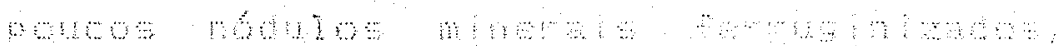
tamarto yar ado, duro, forma rmeglar,

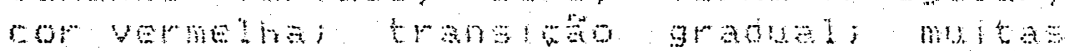

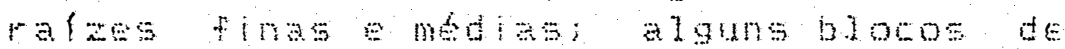


(A12) 8 - $15 \mathrm{~cm}$ :

granito pouco alterado mantendo a sua cor cinar na parte mais interna, avermelhada na regiäo semialterada amarelada na sida periferiaj

Cor IOYR A/A (brino amarelado Escurb): $62,6 \%$ cascalho, 37,4 \% TFSA; sextura franca-arenosa; estrutura em blocos subangulares, pequena, fraca, poros comuns, pequenos; consistencia, frikvel, nहैo plástico, näo pegajoso; poldcos nódulos minerais ferruginizados, sananto variado, duro, forma irregular, cor vermelha: transicato gradual; mulas raízes tinas e méclias; aguns blocos de granito fouco alterado mantendo a sua cor cinaa na parte mais interna, avermelinda na resia seni alterada e amarelada na sua periferia;

(B1) $15-25 \mathrm{~cm}$ : Cor $10 Y R$ $5 / 6$ (bruno amarejado); $53,0 \%$ cascalho, 47,0\% TFSA; texira francaargila-arenosa; estrutura en blocos subangulares, média, fraca; poros comus, pequenos; consistêneia, friál, näo plástico, náp pegajosoi poldco: nódulos minerais ferruginizados, "tamanho variado, duro, forma irregldar, cor vermeltha;

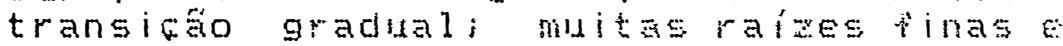
médias; alguns blocos de granito pouso alterado, mantendo a sua cor cinza na parte mais interna, avermelinads na ratán semi-alterada e anarelada na sua periferiai

(B2) $30-50 \mathrm{~cm}$ : Cor $10 Y R$ $5 / 8$ (bruno amarelado); $41,7 \%$ cascalho, 58, O\% TFSA; textura francaargilosa; estrutura em blocos subangulares; média, fraca; poldcos poros. pequenos; consistência, frisuel, ligeiramente plastico, ligeiranente pegajoso; poldeos nódulos minerais ferruginiados, tamanto variado, dido. forma irregular, cor vermeihai tranglato abrupta para as rochas; varios blocos de granito pouco alerado, mantando a sua cor cinar na parte mais interna, avermediada na regíío semi alterada e amarelada na sua periferia;

(CA) $70-80$ cn: Granito pouco alterado, apresentando regises com cor vernelha em funcio da alteraço do granito; nas fissiras das rochas, desenvolve solo de cor brino anare lacio:

(ce) 100-110 cm: Camada apresentando arena vermesho-amare lada, frílyel tendo na sua base uma fax de $1,5 \mathrm{~cm}$ de expessira com processo de hidromorfia incipiente. 
. Descriráno geral

PERTII NAE

Data $=$ maio/1.986

Classificactio = Cambissolo Tb nö́o álico, A moderada. textura media, floresta ombritia aberta tropical, relevo forte ondulado, substrato granito.

Situacáo, declive e cobertura vegetal = perfil localizado no terco médio da vertente com declive de is\%, loresta primitiva

Altitude $=200$ a 300 metros

Litologia e cronologia = granito intrusivo Tejes pires do Grupo varumä, préceambriano superior.

Mateiral originario $=p$ poduto da alteraga da rocha supracitada.

Pedregosidade maros calhaus na superificie do solo.

Rochosidade $=$ ausents.

Relevo local = montanhoso.

Relevo regional = forte ondulado.

Erosä́o = laminar ligeira.

Drenazem = bem drenado.

Uso atual = nenfum.

Sil ina

$=A m$ (Koppen) Elima equatorial quente úniog.

- Descricâo Morfológica

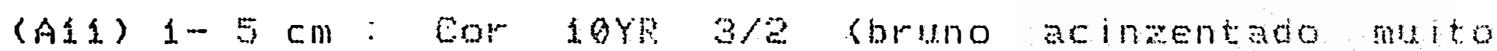
escuro); $19,0 \%$ cascalho, $81,0 \%$ TFafifranco arenoso; estrutura srumosa, pequena, fraca; muitos poros fendenos; consisten

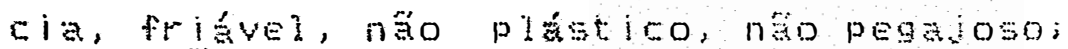
transicăo clara; mulas ralzes finase medias; alguns nodulos minerais ferruginizados, duro, cor vernelina.

(A12) 5 - $10 \mathrm{~cm}$ : Cor $10 Y R$ 4/6 (bruno anarelo escuro); $14,6 \%$ cascalho, $8 \%, 4 \%$ TFSA; franco argilo arenoso; estrutura en blocos subanguares, pequena, fraca; mutios poros pegunon; consistancia friável, nä plastico, nöo

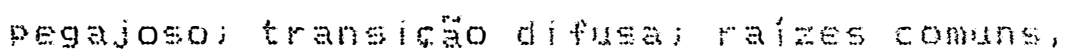
finse, médias e algumas grossas, alguns nodulos minerais ferruginiados, duro, cor vermelhat.

(B11) 10 -..20 cn: Cor loYr $5 / 6$ (bruno anarelado); cascalho, $89,2 \%$ TFSA; franco argilo arenoso; estrutura em blocos subangulares, pequena, moderada: poros comuns, pequenos, consistencia fridvel năo plastico, năo pegajoso; transicto difusai mitas ratzes

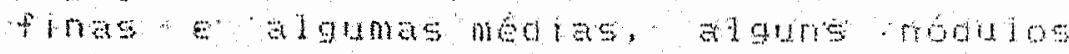
ninerais ferruginizados, duro, cor vermelha. 
(B12) $20-30$ cn: Cor sorp $5 / 8$ (bruno amarelado); $21,8 \%$ Cascallo; $78,2 \%$ TFSA; francomargilow arenoso; setrutura em blocos subangulares, média, fraca; poros comuns, pecuenos; consistencia friável näo plástica, náo pegajoso; transiczo gradua!, irregular; poldes raínes finas, alsuma: medias; alguns nódulos minerais ferruginizados, duro, cor vermelta.

(813) 30-40 cm: Cor 10YR 5/8 (bruno amareiado); 28, $7 \%$ cascalho, 74, i \% TFsa; francomargiloarenoso; estrutura en blocos. Eubangulares, media, fraca; poros comins, pequenos; consistencia friáve! nâto plabico. náo pesajoso; traneisio gradual, irregular, poueas rátes, rinas, alumas medias, alguns nodulos ferruginizesos, duro, cor vermelha.

(B14) $40-50 \mathrm{~cm}$ : Cor 10YR $5 / 8$ (bruno amarelado); 24, $4 \%$ cascaitro; 7\%,6\% TisA; franco-argilom arenoso; setrutura en blocos subangularss, media, fraca: poros comms, pequenos: consistencia triavei, náso plástico, näo pegajosoi transigäo gradual, irregular, poucas ráles finas se mediasi aleuns nódulos minerais terruginlados, duro, cor vermel ha.

(B21) $55-65$ cm: Cor $5 Y R$ 5/8 (verme tho amarelado); 28,2\%

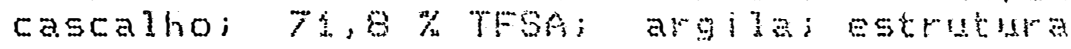
en blocos angulares, méla, fortei pousos poros pequenos; consistencia firme ou coeso, ligeiramente plastlob, I igeiramente pegajoso; transicia grodual, irresular; poucas raizes finas e medias; alguns nódulos ferruginizados, duro, cor vermelta.

(B22) $75-85 \mathrm{~cm}$ : Cor $5 Y k$ 5i8 (vermelho amarelado); con linguas de material com cor $7,3 y p$ b/g (anarelowavermelhado) gue desenvolven nas fissuras; $21.6 \%$ ascalno; $78,4 \%$ THEA; argila; estrutura en elocos angulares, media, forte, poucos poros pepyenos; consistencia firme ou coeso, I geiramente:

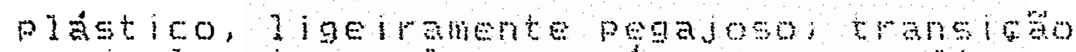
gradual, irresular; ralzestrias, finas, algune nodulos manerals ferruginiados. duro, cor vermelho; ajgun blocos de granitos isolados.

(B3) 120-130 cm: Cor $5 Y R$ $5 / 8$ (vermelho amarelado); i7, $4 \%$ cascalho; 82,6\% THSA; francowargioso; estrutura en blocos subangulares, pequena, fraca; poros comuns, pequenos; consis.

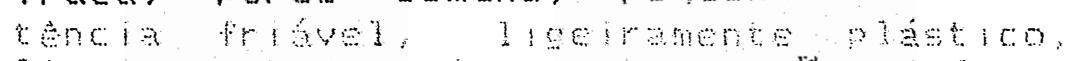
ligeiramente pegajoso; transiso difusa, irregular; ralzes raras, finas; adguns nodulos minerais terruginizados, duro, cor 


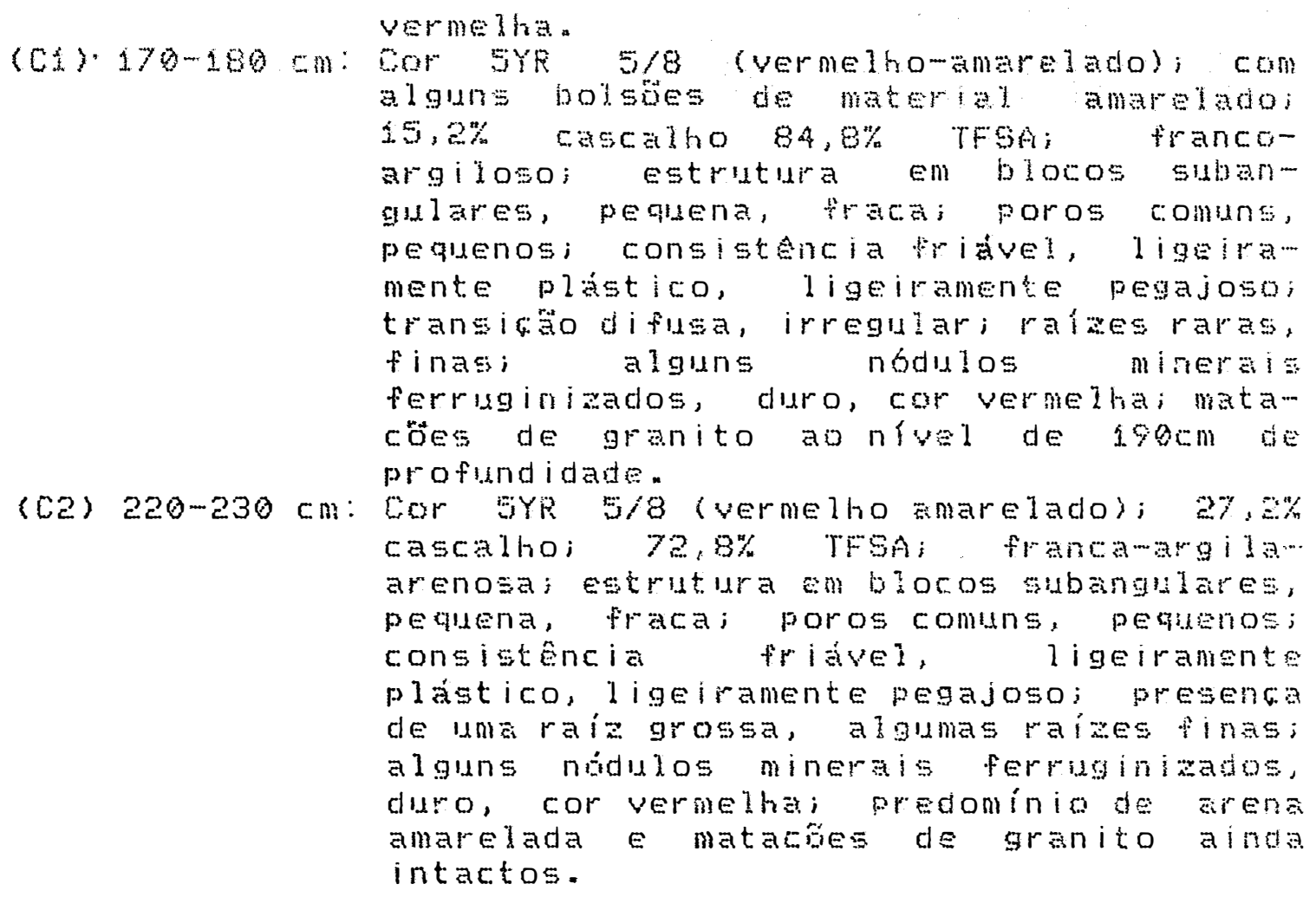

- Descrifio geral

Perfit NAB

Data $=$ maio/1986

Crlassificacto m Cambissolo Tb näo élico, A moderada, textura media, floresta ombrófila aberta tropical, relevo forte ondis ado, substrato stanito.

Gituacto, declive e cobrtura vegetal = perfil localizado no terco inferior da vertente com declive de $20 \%$, floresta primitiva.

Altitude $=200$ a 300 metros.

Litologia e cronologia = granito intrusivo Teles pires do Grupo Uatuma, pre-canbriano superior.

Material orisinerio aroduto da alteracio da rocha supracitada.

Pedregosidace = Wirios calhas na superticie do golo.

Rochosidade = diversos matacies na superficie do solo con dimensose var ladas, atloramentos de matacos maiores bem prósimo ao perfil.

Relevo local mo montanhoso.

Relevo regional =: forte ondulado.

Erosío = laminar ligeira.

Drenagem = bem drenado.

- Descrigáo Morfologica

(Af) $2-8 \mathrm{~cm}$ : Cor SOYR $3 / 2$ (bruno acinzentado muito 


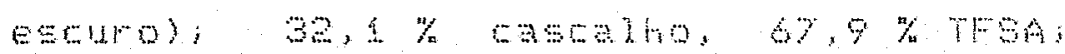
francomarenoeoi estutum subangular,

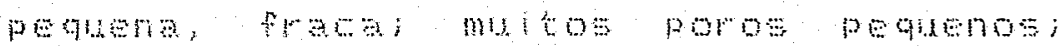

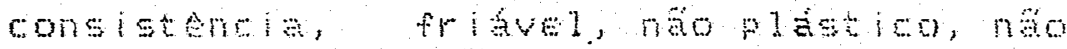

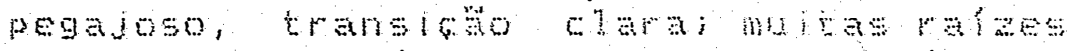
finas e medtas; alguns nodulos ferrughizados, duro, cor vermetha.

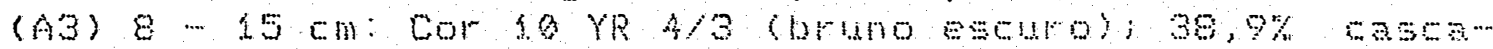
Tho, 61,4\% TFSA fancomglomarenoso:

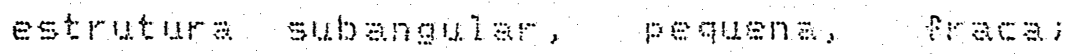
mutcos poros peruenos; coneistemeia, frituet, no plastion, no pesasos.

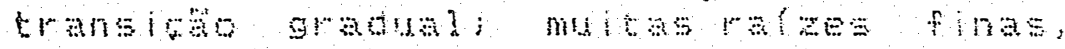

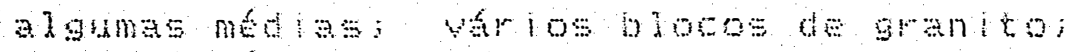
alans nódulos minerais fermanizados, duro, cor vermeltha

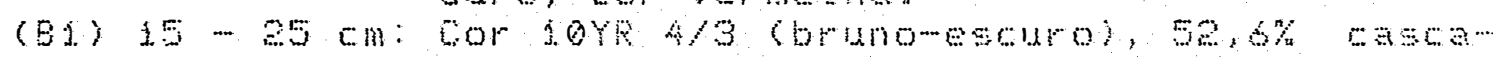

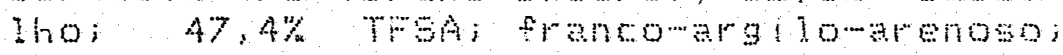
estrutura subangular paqdera, traca; musos poros pequenos; consistenos,

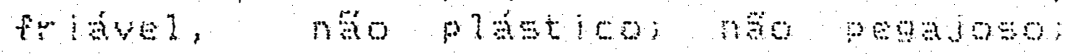

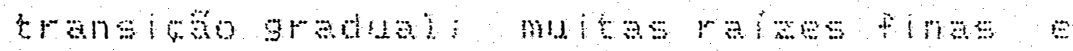
medlas: alouns notulos mitrats

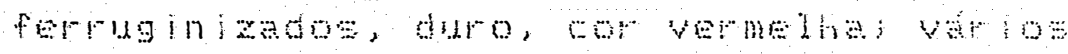
blocos de grantos tatactos.

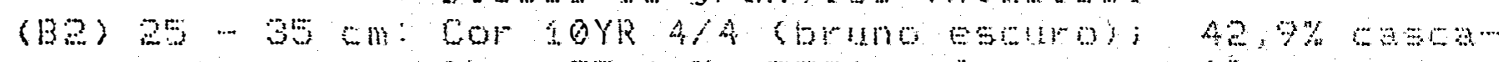

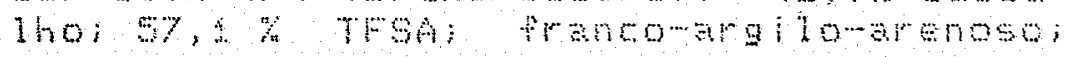

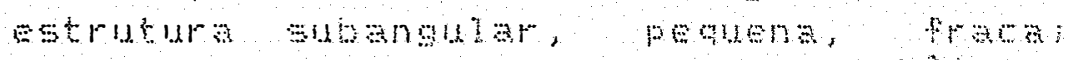
poros comans, pequenos, consistarela,

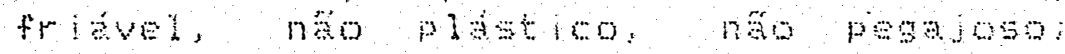

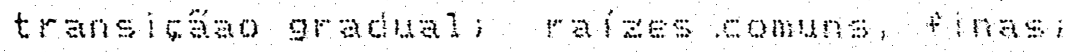
blocos peateno e isolados de grante alguns nodulos minerais fermulatzados, duro, cor vermelna.

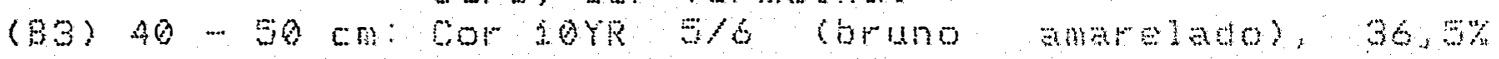

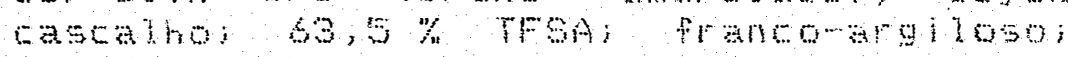
estrutura subanula, pemena, fraco;

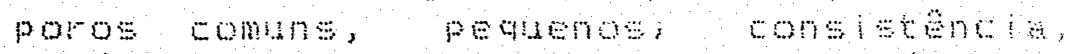

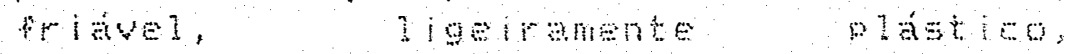

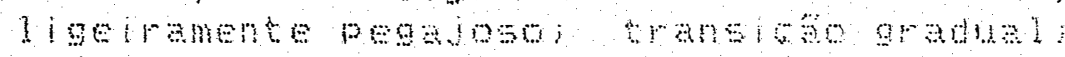

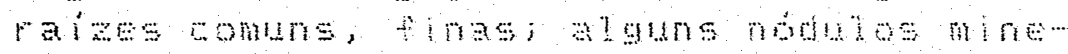

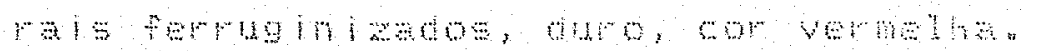

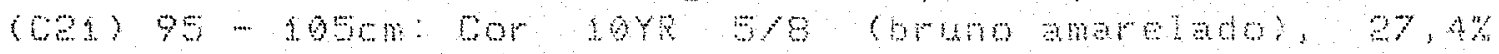

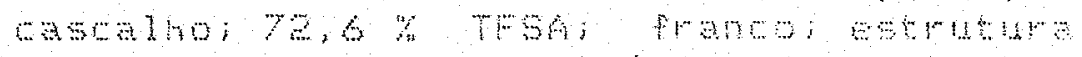

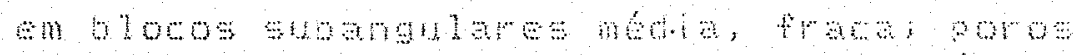

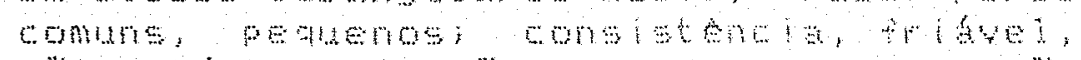
no plástoo, nao pegasos, transio

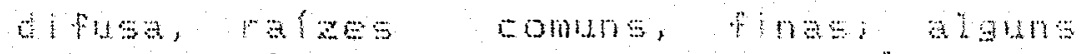
b? ocos isolados de granto rominane da arena grantis amarelata.

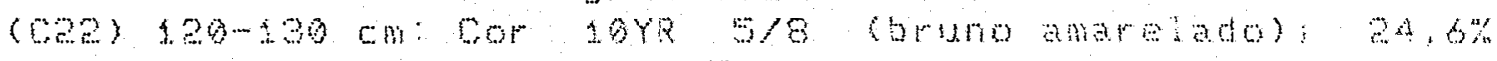

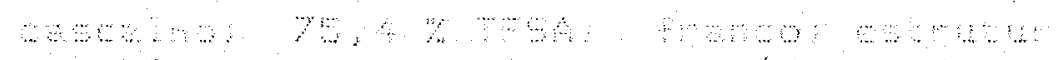
en blocos subnolares, media, prani poros comms, pequnos, ronsistenota,

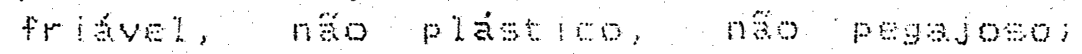


transiga offusa; ratase romus, finas; aloms blow de orantos deolatos.

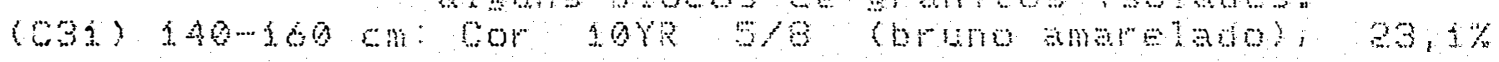

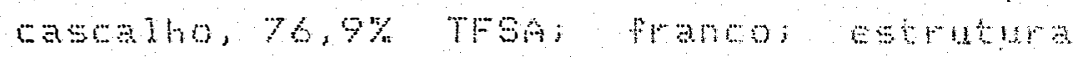
subanguar pequna, fraca poros comune, pequenos; consistenta frituel, net plático, no pegajoso, transiat d flas, ralzes poucas, finas; algun blocos de granito anda intactos; dominane a da arena granistea amarelads.

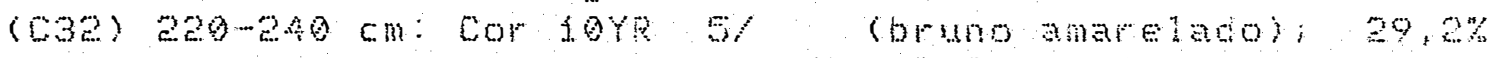
cascino; 70, 8\% TFSA, franowarenos; estrutura en blocos subangulares, pequena. fraca, poros comms, pequenos, consis tencia frlavel, ne plasted no

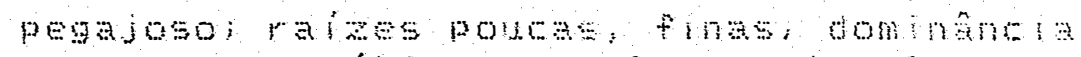
da arena granitica amarelada ma is olara.

\section{Topossequêneia NB}

\section{Deseriono geral}

Perfi? NBS

Data mas $10 / 1966$

Classifinacio = Cambissolo Tb na dico, A moderada,

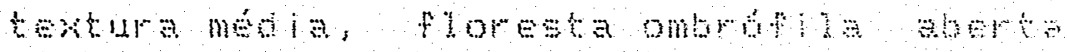

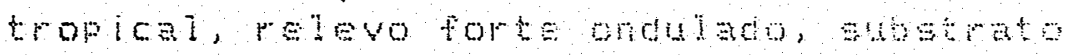
aranito.

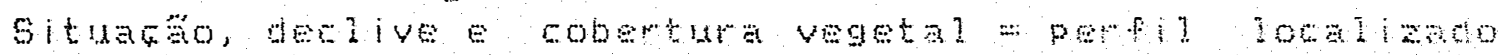
no terbo méto da vertente con desive de 25\%, floresta printiva.

Altitude = 200 a 300 metros.

Litologia e cronologia m granto intrustvotelesplres do Grupo Uatume, prewambrano smortor,

Material originario = produb da alterabo da pona supras isidan

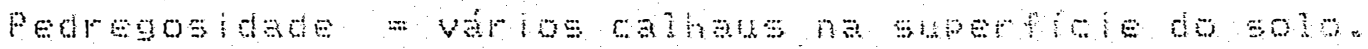

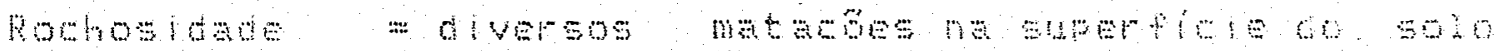

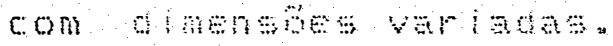

Relevo lomal momanoso.

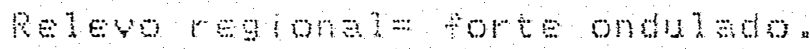

Donagem $\quad$ -

\section{- Descrifáo morfoldigica}

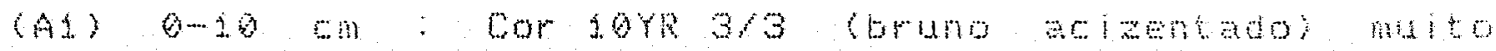

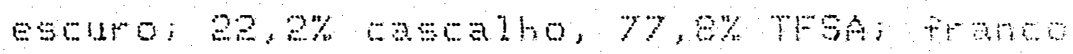
arenoso; estrusura grumosa pent pen

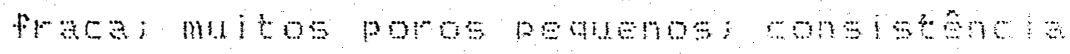

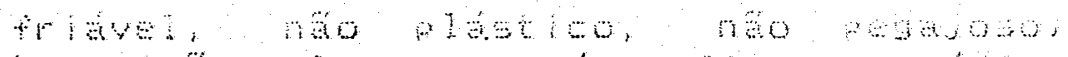

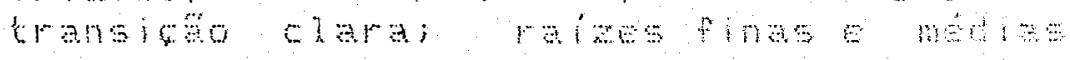
aundantes;

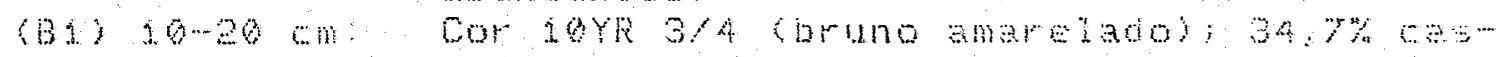




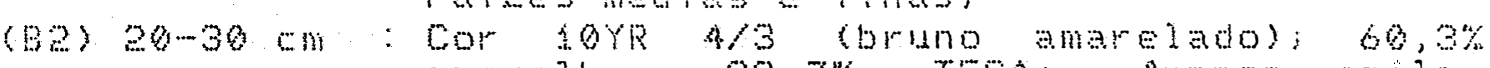

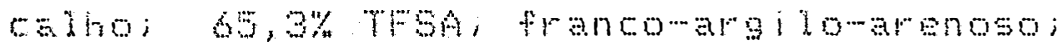
estrutura em blocos subangularss, pequena, moderadaj poros comms, peruenos;

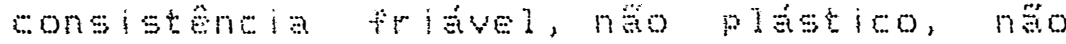
pegajoso; transiono gratal; algumas ralies medias finas; cascalho, 39,7\% TFeA franco-argiloarenoso; estrutura em blocos subangutares, média moderada; poros combns, peduenos; consistencia friavel, nio plastico, näo pegajosoi transicád difusa.

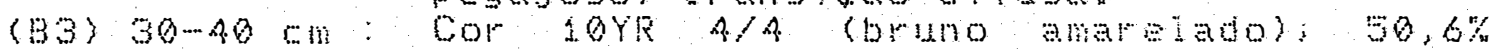
cascalho, A8, a\% TFSA, francomedioarenoso; estrutura em blomos gubangulares. média, moderada; poros comuns, peatunos: consistencia friavel, näplastos, nä pegajoso; transiço difusa e irregular.

(011) so-go cm: Amostra constidida pela arena grantica avermelhada; cores variadas: $2,5 \mathrm{p}, 4 b$ $(\because .80 \%), \quad 10$ YR 46 (*) $20 \%), 41,0 \%$ cascalho, 59, on TFsA; franco argitoso,

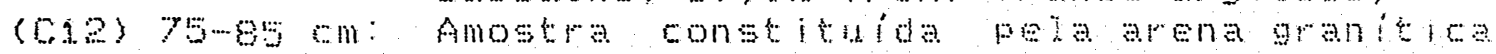
avermelhata; cores variadas: $2, y$ YR $A / \theta$

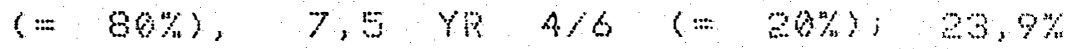

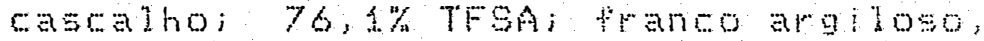

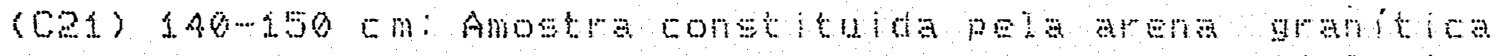
avermelhada cores vartadas 10 R $4 / 8$ $\{=3(\%) ;$ LYYR $5 / 8(-3 \% \%), 2,5$ YR $5 / 8$ $(=30 \%), \quad 14,6 \%$ cascolho, $65,6 \%$, francomarenoso.

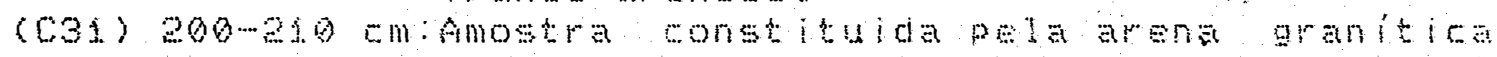

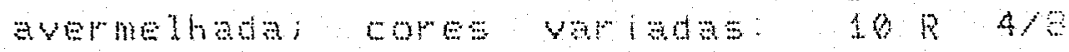
$s=60 \%), \quad 2,5$ Yर $5 / 8(=40 \%) ;\{3,9 \%$ cascalto, so, h\% THs ; franco arenoso.

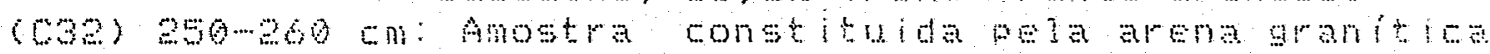
mals evoluida, colebada na mona protundida da arena panita raved;

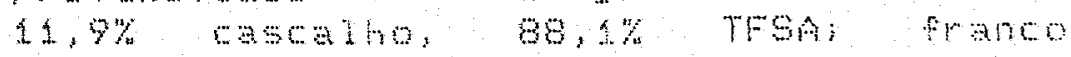
arenogin

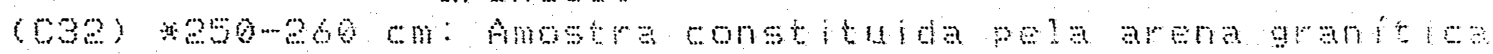

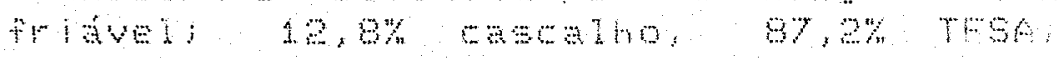
Preston

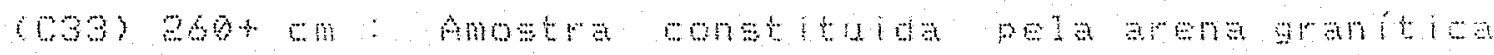

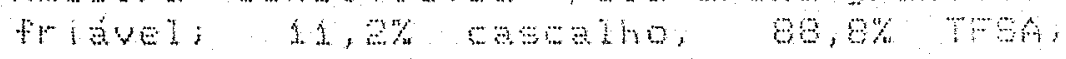
francomarenoso.

\section{2 - Descriqäo Micromorfoligica}

Toposesequencia NA

PEFfil NAE

(A11) 1 a $5 \mathrm{~cm}$ de profundidade: 
Fundo Matricial:

-Esqueleto: Abundante representando $40 \%$ do volume total do fundo matricial; constituido quase que exclusivamente de grä́os de quartzo (75\%) angulosos, alguns ben fraturados, os quais ira se dispersar em fragmentos menores no plasma; ocorrencia esparsa de fragmentos em alteracto de feldspato potassico na forma de microclina $(15 \%), \quad$ constituindo ocasionalnente guros complexos de minerais juntamente com quartzo conservado e a microclina, em alteracăo mas muito ben caracterizada ainda $e$ com suas fraturas de borda ja ferruginizada ocorrencia esparsa de palhetas de biotita (5\%) ja bem alterada; em igual os minerais em alteracio estäo impregnados por compostos de ferro de coloracto vermelho vivo pouco translucido provalvelnente na forma de hematita; plagioclasio ausente.

- Materia organica bruta: representa $5 \%$ do volume total do fundo matricial na forma de pequenos tragmentos näo translucidas (opaca) com raizes em via de decomposic ato ou humificadas.

-Plasma : representa $35 \%$ do volume total do fundo matri-.. cial; de coloracäo bruna-amarelada-escura isoyk 4/6) en funcä́ da concentracádo da matéria orgânica coloidal; apresenta uma estrutura plásmica do tipo "argillasepic" con tendencia incipiente de alguns pontos a separacäo plásmica em torno do esqueleto ou seja com estrutura plásmica "skelsepic"; distribuiḉo relativa da plasma e do esqueletoé do tipo "gefuric" ous aglameroplásmica; observa-se no plasma, vários grânulos minúsculos de coloraço escura, $10 x$ e com luz direta, apresentam cor vermelha bem viva caracter istica dos agregados organo argiloso.

- Varios: representa $20 \%$ do volume total do fundo matricial; ortovazios constituidos por fissuras transagregados intercomunicantes nas formas obliquas - "skew planes" e rachaduras -.. "craze planes", dominio dos macroporos e em menor grals mesoporos.

Feíges pedoligicas:

Glebulas: alguns nodulos de natureza ferrica de cor vermelha escura (hematita), outros nodulos totalmente opacos mesmo em luz direta.

(811) 10 a $20 \mathrm{~cm}$ de profundidade:

Fundo. Matricial: 
- Esqueleto: Abunante representa $58 \%$ do volume botal do fundo matrielas; dominane la de gras de quatao (7ow), angulosos, alguns fraturados, alouns na forma conchoidal, as vezes imprenatos com bxidos de ferro nas suas fissuras oforencia da microclina (2o\%) em diferentes graus de alteracio, apresentando en algumas fissuras impregnacoes de bxido de ferro; $7 \%$ de biotita em grau avancado de alteracio, alguns na forma de pseudomorfos todos esparsamente distribuldos no fundo matricial; alguns grasenomes de plagioclisio parcialmente intemperizado e com importara de compostos de ferro nas suas fissilkasio

- Hateria organica bruta: representa aprowimadanente $3 \%$ do volume total do fundo matricial; säo diversos fragmentos de materia organita bruta näo idene ifickel de cor prexa, alguns fragmentos de raizes.

-Plasma : representa $35 \%$ do volume tota? do fundo matricial; de cor amarela brunada $40 Y R$ bia, apresentando pontuages avermethados dewido a concentrazo de maśria orsanica colotal complexada com a prazo minera do plasma; estrutura plásia do tipo argilasepie", alguns pontos apresentando tendencia a separano plasmisa en tomo do esuelero constituindo o tipo skelsepic": distribuica relativa do plasma e do esqueleto e do tipo "porfiric" ou porfirosolelica, com algumas areas tendendo para "gefuric".

-Vazios : representa $7 \%$ do volume total do fundo matriciai, transagregado, tsestral sendo dominante as rachaduras "crawe planes" a am obliquas "skew planes, secundir iamente canals a cavidades pequenas.

Feicbes pedologicas:

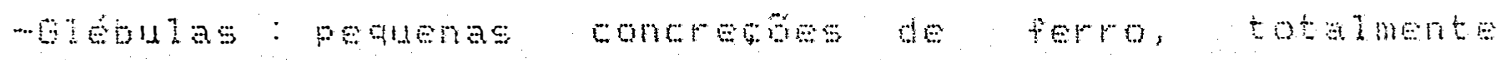
opaces.

(B12) 20 a $30 \mathrm{~cm}$ de profunidade:

Fundo matrie ial:

-Esqueleto: Abundante, representa $55 \%$ do volume total do

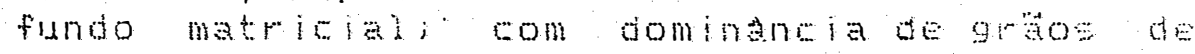
guarto (69\%), angulosos, alguns bem fraturoos

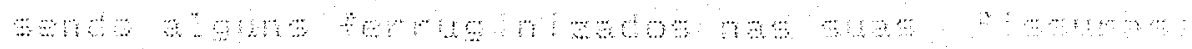

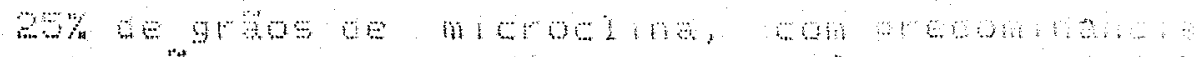

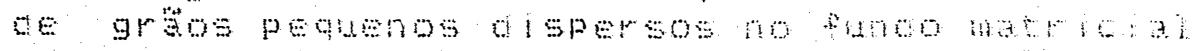
en varios niveis de alteracto, alguns artos sato bem desenvolvidos; $8 \%$ de gräos menores de 
plagioclasios tamben dispersos no fundo matricial, alén dos pseudomorfos de biotita esparsamente distribuidos.

-Materia organica bruta: representa aprowimadamente $2 \%$ do volume total do fundo matricial e säo distribuldas por fragmentos de rafzes en decomposicto, apresentando coloracăo rosa viva.

-Plasma : representa $35 \%$ do volume total do fundo matricial; apresentando cor anarela brunada lOYR b/8; estrutura plasmica do tipo "argiliasepic" com alguns pontos tendendo a "skelsepic"; distribuicato relativa do plasma e do esqueleto do tipo "porfiric." tendendo a "skelsepic" em alguns pontos.

-Vazios : representa $10 \%$ do volume total do fundo matricial, transagregado, fissural, sendo dominante as rachaduras craze planes" e obliguas "skew-planes", secundariamente os canais e cavidades pequenas.

Feicöes pedolbgicas:

- Glebulas : na forma de nodulo grande de natureaa ferrica de cor vermelha escura (hematita), con diversas fissuras na sua massa e tamben, nodulos opacos aleatoriamente distribuldos no fundo matricial.

\section{(B13) 30 a $40 \mathrm{~cm}$ de profundidade:}

Fundo matricial:

-Esqueleto: Abundante, representa $55 \%$ do volume total do fundo matricial; cerca de $75 \%$ constituido por graos de quartzo, angulosos, fraturados alguns na forma conchoidal, predomínio de fragmentos menores dispersos no fundo matricial; $22 \%$ de feldspato potassico na forma de microclina em vários niveis de alterafäo, predominando cristais pequenos, alguns cristais grandes; $3 \%$ de palhetas de biotita dispersas no fundo natricial.

-..Materia organica bruta: constitulda por fragmentos de. ralzes e representa $2 \%$ do fundo matricial.

-.plasma : representa $3 \% \%$ do volume total do fundo matrieial; de coloraço amarela brunada joyk 6.8; estrutura plasmica tipicamente "argillasepic"; distribuicáo relativa do plasma e do esqueleto na forma "porfiric"; obeserva-se peglienos grânulos de compostos orgânicos coloidal complexados com a fracio mineral do plasma, apresentando colorazáo avermelhada translícida.

yanios : representa $10 \%$ do volume total do fundo matricial; transagregado, fissural, sendo dominante as rachaduras "crazeplanes" e as 


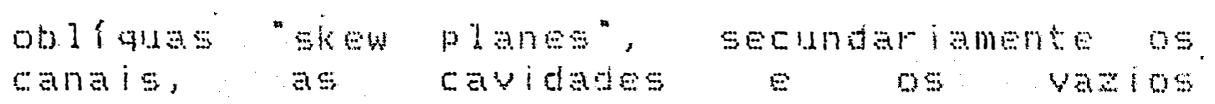
intergranuar

Feiches pedolbgicas:

-Glebulas : nodulos de natureat ferrica totalmente opacos.

\section{(B21) 55 a 65 cm de profundidade:}

Fundo Matricial:

-nscueleto: Abundante, representa $58 \%$ do volume total do fundo maticial; constituido an sua grande maioria por gros de auarta $(70 \%)$, angulosos, alguns bem fraturados, com predominio de fragmentos menores dispersos no fundo matricial; 20\% de feldspato potsssico na forma de microwlina en alserarato com preominio de cristais pequenos dispersos aleatoriamente no fundo matricial; observa-se pacotes de palhetas de biotita (10)\% e seus pramento ds bem alceradose distributos nas suas periferias"

Plasma : representa $3 \%$ do volume sotal do fundo matricial; com coloracato amarelada 10YR $7 / 8$; estrutura plasmica do tipo "argiliasepic"; distribuica relativa do plasma e do sesuleto na forma "porfirie", com tendencia incipiente d

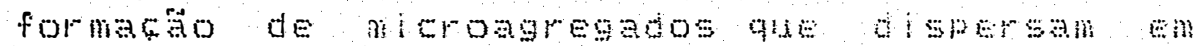
alguns pontos do fundo matrioral condicionando

Varios : formas dotipo "geturic"e "enaulic".

Feicoes pedologicas:

(B22) 75 a 85 cm de profundidade:

Fundo matricial:

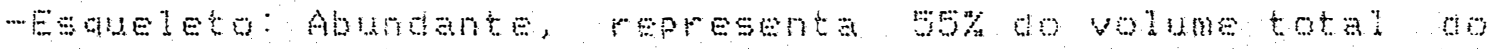
fundo maticial i com domimane dos gros de

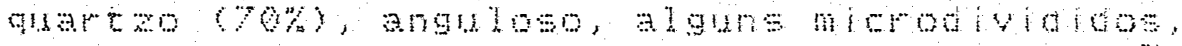
predomine pagmertos menmes tue esto

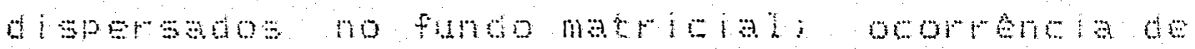
feldspato potsseico na porma de mitocina $(20 \%$ em alteragso, predominano erigats pequenos que ssso dispersos no fundo maticial, varlos pacotes de palhetas de biotita (10\%) rom seus pramentos y ben intemperizados a distributas nos sese weristion.

mpasma a representa $3 \%$ do volume total do fundo

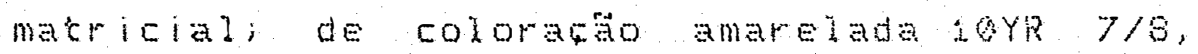




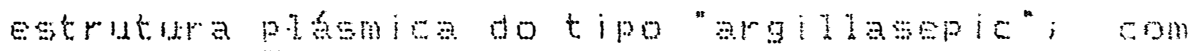
distributato relativa do plasta o do esmeleto dominanco as formas "gefurio" e "enaulic" e en menor gran, ocor"e a forma "por"tric"; formacas

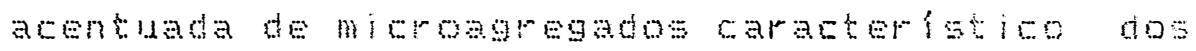
oxissolos os qual: tendem a se dispersar no findo masticial do solo.

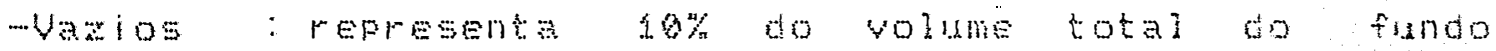
matriciaz; sendo dominante os vasios intergranilares e as fissura nas formas de rachadiras "craze-planes" e obliqus "sken plane:" transagreatos, ororre tambem cavidado grande a a ans canats pequenos.

Feicos:penologisas:

Colsbulas : pequenos nodulos de natureza ferria.

\section{(B3) 120 a $130 \mathrm{~cm}$ de profundidade:}

Findo matris:ial:

…Eshldeleto: "epresenta wo do volume total do funcio matpicial; const ithido bominatemente por graos

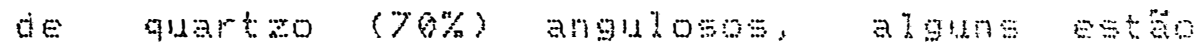

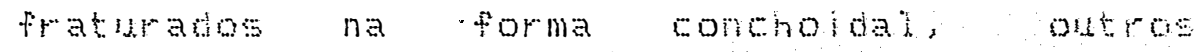
apresentam-se marodivididos mu morofrathados

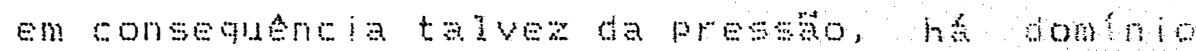
tos fragmentos menores que esto olsosesos no

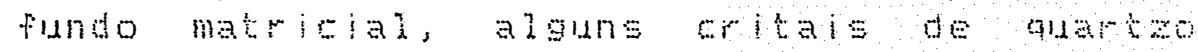

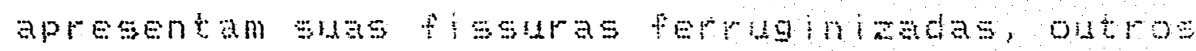

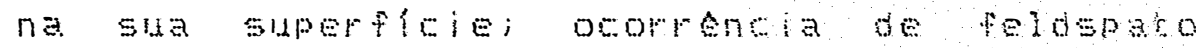
fotsssio na forma de micromina (1) varios n\{veis de alteraso, com o predoninto

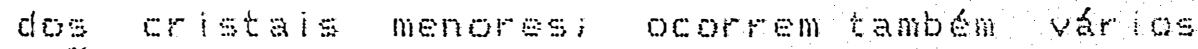
graos complexos no= anis aloms cristais grandes de quartzo enc las anam or istats menores de mlemolina obserame parotes molores de balfeta de biotea (7\%) com suas bordas jo

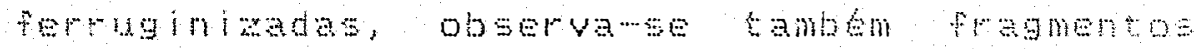

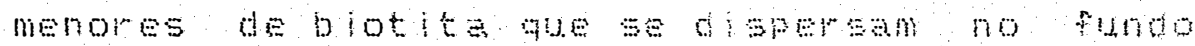

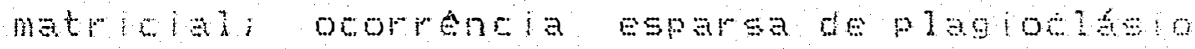

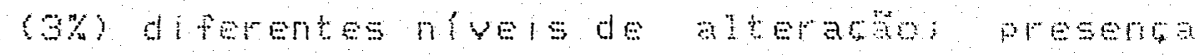

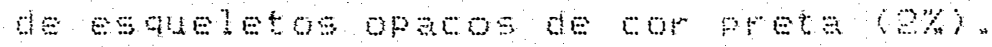

Now

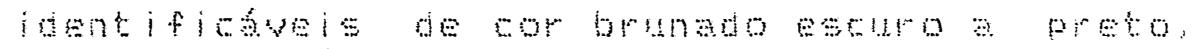

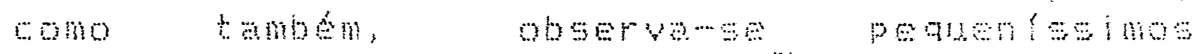

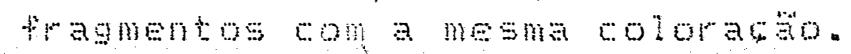

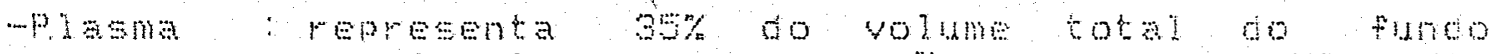
matricial com coloracto amareda

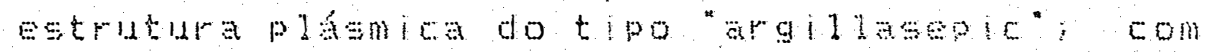
distribugato relativa do plasma do dosobseto

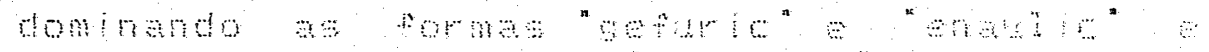

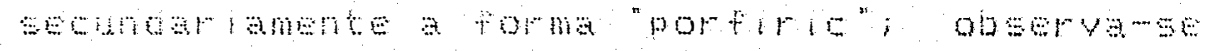
Pors bendencia do prasme wa tormar 
$-4 a \div 10$

microagregado bem caracter fscico do

$0 \% 155010=$ os ana is se dispersam no fundo matricia?.

representa $10 \%$ do volume total do fundo matrieial; com domintneta dos vazios intergrambares ben combleates e grandes fisiras na forma de rachaduras "eraze planes" e obl cous "sken planes" transagregados.

Feicöes pedologicas:

-Glebulas : observa-se nodulos ferricos com microfiseuras.

\section{(C.2) 220 a 230 cm de profundidade:}

Fundo matrieial:

-... Esquedeto: abundante, pepresentando $50 \%$ do volume total do fundo matrie als conetitu do dominantementa por gräos de quartzo (70\%), angulosos, alguns fraturados, com dominio de fragmentos menowes que estäo dispersos no fundo matriciaz; ocorrentia freauente de teldspato potsseicona

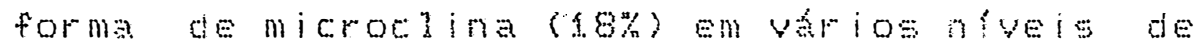
alteraso, as veres, na forma de "gräs complexos" de minolina incluso em gräo de quartzo bem desenvolvido e intacto.

...Plasma : representa $35 \%$ do volume total do furdo matrialial com coloracio amarelada $50 Y$ r $7 / 8$; estrutur plasmica dotipo "argillasepic" con distribuicato relativa do pasma do escuelato dominands as formas "gefuric"e "enaulie" e en menor ocorrencia a forma "porfiric" em alguns pontos do fundo matriciat; obseryase com baspante nitder, a formacto de miroaresados que estao dispersados no fundo matricial bem caracteristicos dos oxissolos; em alguns poncos, observase o plasma impregnado por compostos de ferro.

- Varios : representa jo\% do volume total do pundo matricial com dominantia dos vazios interaranuares ben commicances, fae litando boa dranagn; observase tambn grandes fissuras na fome de rachadure "orame planes" e obl tuas" "sken planes" transagregados.

\section{Perfil NA3}

(A1) 2 a $8 \mathrm{~cm}$ de profundidade:

Fundo matricial:

Esmeleto: mepresenta so\% do volume tota to pundo

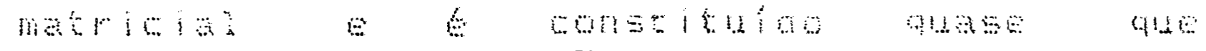

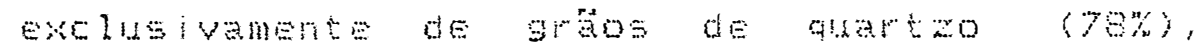


angulosos, alguns fraturados, grande guantidade de fragmentos menores de guartzo que estato dispersos no plasma; ocorrencia esparsa de gräos e fragnentos em alteracăo de feldspato potassico na forma de microclina $(15 \%)$, observa-se alguns gräos complexos de microclina com quartao inteiramente conservado, alguns gräos de microclina säo bem desenvolvidos e no est:áo atual, estäo todos em avancado grau de alteracato; ocorrencia esparsa de plagioclásio (5\%) em alteracato e nas suas fissuras observase a neoformacäo de minerais secundarios, alguns gräos de plagioclasio ocorre tambén na forma de grăos complexos con quartzo conservado; ocorrencia esparsa de pseudomortos de biotita (a\%) condicionando coloracăo avermelhada na sua periferia.

- Materia organica bruka: representa $7 \%$ do volume total do fundo matricial, na forma de pequenos fragmentos nato tanslícidos (opacos) e näo identificaveis; observa-we tambem fragmentos identificaveis de rafaes em decomposităo apresentando cor vermelho escuro vivo pouco translúcido; há ocorrencia tambén de pelotas fecais (fecal pelletsi, observando no seld interior inimeros agregados vermeihos formados em funcä́o da matéria organica en estado coloidal num plasma de coloracäo anarelada.

-Plasma : representado por $30 \%$ do volume total do fundo matricial; apresenta cor $10 Y R$ $4 / 6$ - bruno amarelado escura, pouca transparencia, com distribuicăo relativa do esqueleto do plasma do tipo "gefuric" tenderdo a "enaulic", estrutura plasmica do tipo "skelsepic".

- Vazios : representado por $33 \%$ do volume total do risudo matricial, predoninando formas em fissuras, algumas cavidades manilares e complexos.

Feicóes pedologicas:

- Glebulas : observa-se grande quantidade de granulos envolvidos por materia organica coloidal, de cor avermelhada viva e pouco translacidos.

(B1) 15 a $25 \mathrm{~cm}$ de profundidade:

Findo matricial:

-Esqueleto: representa $55 \%$ do volume total do fundo matricial; constituido quase que exclusivamente por grăos de quartio $(80 \%)$ com predonfnio de grasos pacuenos que esta disforsos no plasma; ocorrencia esparsa de feldspato potássico na forma de microclina $(5.5 \%)$, com predonínio de gräos ou fragmentos pequenos, todos em 
alteractio e suas fissuras já ferruginizadas, alguns gräos de microci ina ocorren na forma de gräos complexos com quartzo conservado; o plagioclásio ocorre em menor percentual, ou seja, em torno de $5 \%$, com predomínio de gratos pequenos, todos en alteraciar alguns indicios de pseudomorfos de biotita säo observados en virtude da cor mais avermelhada do fundo matricial na sua periferia.

- Materia organica bruta: representa cerca de $5 \%$ do volume total do fundo matricial, sendo constituido por fragmentos de ralzes en decomposica e com cores avermelhadas escuras e näo translucido.

-Plasma : representa cerca de $30 \%$ do volume total do fundo matricial, com cor poldca transparencia, com distribuicaro relativa do esqueleto e do plasma do tipo "gefuric" tendendo a "porfiric" E estrutura plasmica do tipo "arsillasepic" a "skel sep ic".

-Vazios : representado por $10 \%$ do volume total do fundo matricial, com predominio de vazios fissurais (craze planes) e secundariamente por canais (skew planes) e cavidades mamilares.

(C31) 140 a $160 \mathrm{~cm}$ de profiundidade:

Fundo matricial:

-Esciueleto: representado por $55 \%$ do volume total do fundo matricial, com dominancia dos gräos de quarta (70\%), angulosos, alguns fratirados; ocorrencia de microclina $(15 \%)$, biotita $(15 \%)$ em alteracato, ocorrendo ocasionalmente pseudomortoses da biotita com 6xidos de ferro tendo em seu centro algumas palietas de biotita facilmente identificavel.

-plasma : representa \% do volume total do fundo matricial;

\section{Topossequência NB}

Perfil NBI

\section{(C12) 75 a $85 \mathrm{~cm}$ de profundidade:}

Fundo matricial:

-Esqueleto: representa $55 \%$ do volume total do fundo matricial; tendo como mineral predominante o quartzo $(50 \%)$, angulosos, alguns con fraturas de forma conchoidal, impregnacko por compostos de ferro de cor vermelha na superticie de alguns cristais $25 \%$ de feldspato potássico na forma de microclina en alteractoi ac\% de 
biotira na forma de pacotes de palhetas como tambeim eim pequenos frägmentos que estäo dispersados nas suas periferias dentro de un plasma de cor avermelhado en funcáo dos compostos de ferro liberados no processo de alteracio da biotita; $3 \%$ de esqueletos na forma de opacos náo identificaveis e aleatoriamente dispersados no fundo matricial.

-Plasma : representa $30 \%$ do volume total do fundo matricial; apresenta cor amarela avermelhada $7,5 Y R$ 6/8, influenciado pela maior quantidade de compostos de ferro liberados no transcorrer da alterasa da biotita; estrutura plasmica do tipo "argillasepic" com leve tendencia a "skelsepic" onde oplasma é mais rarefeito; distribuicato relativa do plasma e do esqueleto ocorre nas formas "gefuric" e "enaulic", ocorre tambem na forma "porfiric" nos pontos onde o plasma está mais concentrado.

-Vazios : representa $35 \%$ do volume total do Fiundo matricial;

(C31) 200 a $210 \mathrm{~cm}$ de profundidade:

Fundo matricial:

-Esqueleto: abundante, representa $55 \%$ do volume total do fundo matricia?; constituldo principalmente por gratos de quarto (55\%) angulosos, alguns com fratura conchoidal, outros ben fraturados, observando-se is veaes nas suas fissuras a impregnacüo de compostos de ferro de cor vermelha, talvez na forma de hematita; ocorre com bastante frequencia o feldspato potassico na forma de microclina (20\%) en diferentes nfveis de alteracto alguns na forma de gräos complexos com cuartao ainda intacto, observa-se com bastante frecuencia que suas fraturas estido normalmente impregnados por compostos de ferro de cor avermelhado escuro e fosco; $23 \%$ de biotita em alteracto, com quantidade significativa de seus fragmentos dispersos no plasma, apresentando coloracá vermelha amarelada, ocorre tamben pacotes de palhetas finas e medias de biotita aina bem identificácisj outros $2 \%$ constituen minerais opacos pretos distribuldos aleatoriamente no fundo matricial.

-Plasma : representa $30 \%$ do volume total do fundo matricial; de coloracăo amarela avernelhada 7, SYY 6.8 decorrente da naior quantidade de biotita presente principalmente na forma de fragmentos avermelhados que estäo dispersos no plasma como tambem, na de pequenissimos 
fragmentos amarelados claros dispersados num plasma de cor acinaentada; estrutura plasmica do tipo "argillasepic" com leve tendencia a "skelsepic" nos pontos onde oplasma 6 mais rarefeito. Adistribuicuo relativa do plasma en relacio ao esqueleto f do tipo "porfiric" com alguns pontos tendendo ao tipo "gefuric".

-Vazios : representa $15 \%$ do volume total do fundo matricial.

(C32) 250 a $260 \mathrm{~cm}$ de profundidade:

Fundo matricial:

-Esqueleto: abundante, representa $55 \%$ do volume total do fundo matricial; predominando gras de quartao $(55 \%)$ angulosos alguns fraturados e as veres na forma conchoidal, no geral nato se observa o processo da ferruginizacäo nas suas fissuras; ocorrencia frequente de feldspato potsssico na forma de microclina $(25 \%)$, alguns gräos ainda intactos, outros apresentando diferentes graus de alteracăo tendo alguns nas suas fissuras o desenvolvimento de um plasma variado com cores amareladas, amarelo avernelhados e cinzentas; $1.7 \%$ da biotita sob a forma de pacotes em quantidades significativas na forma de fragmentos já dispersados noplasma, todos en alteraç̃o e na naioria deles ainda bem identificaveisi raros grä́os de minerais totalmente opacos (preto) ( $3 \%$ ) que ocorren isoladamente no fundo matricial.

-plasma : representa $30 \%$ do volume total do fundo natricial; apresentando coloracaro amarelo avernelhada $7,5 Y R$ o/ 5 ja influenciada pela maior quantidade de biotita cuja alteracăo condiciona pseudomorfos e fragmentos de biotita de cor avermelhada dispersas no plasma de cor nais amarelada quando se obeserva numa magnificacäo de $10-x$ apresenta una estrutura plasmica do tipo "argillasepic" com leve tendencia a separacäo plásmica en torno dos graos de quartzo en pontos onde o plasma 6 ben rarefeito, caracterizando assim o tipo "skelsepic". A distribuicato relativa do plasma em relacäo e no geral do tipo "gefuric", mas nos pontos onde há una naior concentrafä́o do plasma, ocorre o tipo "porfiric".

- Vazios : representa $15 \%$ do volume total do fundo matricial. 